Paul Dobrescu Editor

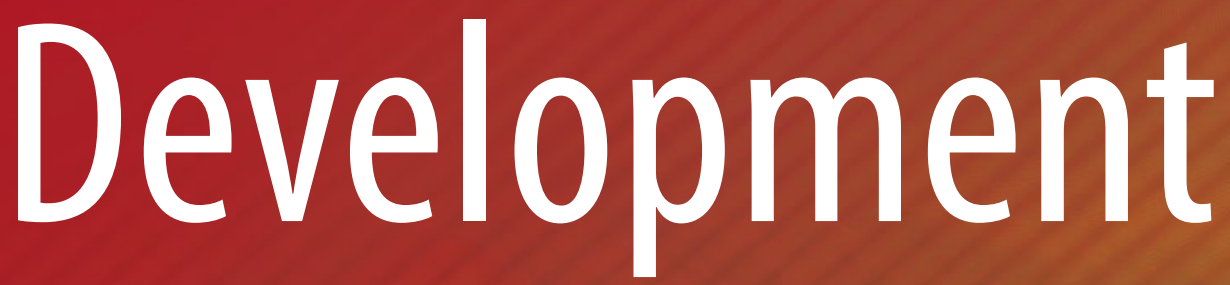

in Turbulent

Times

The Many Faces of Inequality Within Europe

Springer Open 
Development in Turbulent Times 
Paul Dobrescu

Editor

\section{Development in Turbulent Times}

The Many Faces of Inequality Within Europe

第 Springer Open 


\author{
Editor \\ Paul Dobrescu \\ National University of Political Studies and \\ Public Administration \\ Bucharest, Romania
}
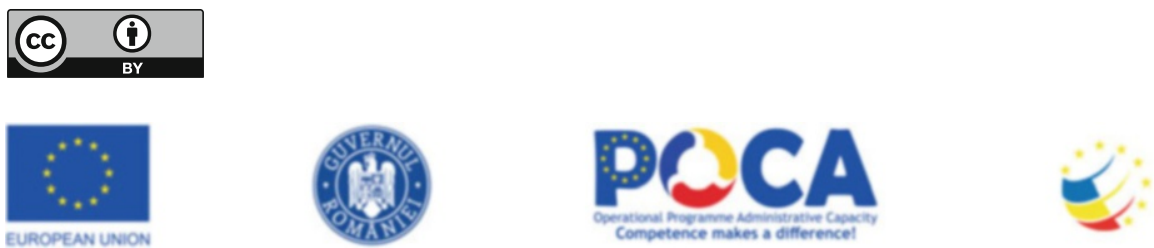

This Open Access publication is based on the project "State of the Nation - Designing an Innovative Instrument for Evidence-Based Policy Making", which was co-financed by the European Social Fund through the Operational Programme Administrative Capacity 2014-2020 under the grant number "MySMIS 118305/SIPOCA 11" and edited by the Secretariat-General of the Government (SGG).

The content of this publication does not reflect the official opinion of the European Union or of the Romanian Government.

ISBN 978-3-030-11360-5

ISBN 978-3-030-11361-2 (eBook)

https://doi.org/10.1007/978-3-030-11361-2

Library of Congress Control Number: 2019930617

This book is an open access publication.

(C) The Editor(s) (if applicable) and The Author(s) 2019, corrected publication 2019

Open Access This book is licensed under the terms of the Creative Commons Attribution 4.0 International License (http://creativecommons.org/licenses/by/4.0/), which permits use, sharing, adaptation, distribution and reproduction in any medium or format, as long as you give appropriate credit to the original author(s) and the source, provide a link to the Creative Commons licence and indicate if changes were made. The images or other third party material in this book are included in the book's Creative Commons licence, unless indicated otherwise in a credit line to the material. If material is not included in the book's Creative Commons licence and your intended use is not permitted by statutory regulation or exceeds the permitted use, you will need to obtain permission directly from the copyright holder.

The use of general descriptive names, registered names, trademarks, service marks, etc. in this publication does not imply, even in the absence of a specific statement, that such names are exempt from the relevant protective laws and regulations and therefore free for general use.

The publisher, the authors, and the editors are safe to assume that the advice and information in this book are believed to be true and accurate at the date of publication. Neither the publisher nor the authors or the editors give a warranty, express or implied, with respect to the material contained herein or for any errors or omissions that may have been made. The publisher remains neutral with regard to jurisdictional claims in published maps and institutional affiliations.

This Springer imprint is published by the registered company Springer Nature Switzerland AG. The registered company address is: Gewerbestrasse 11, 6330 Cham, Switzerland 


\section{Contents}

Part I Envisaging Development in the Contemporary Society: Theory and Public Debates

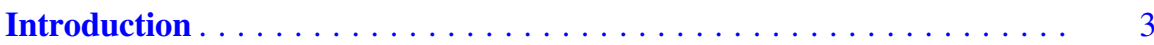

Paul Dobrescu

Why Do Some Countries Develop and Others Not? . . . . . . . . . . . . 13

Ian Goldin

Measuring the Hard-to-Measure in Development: Dimensions,

Measurement Challenges, and Responses .

Anne L. Buffardi, Tiina Pasanen, and Simon Hearn

Get It Right This Time? Leaving the Periphery of the European

Economic Development .

Cristian Păun and Florina Pînzaru

"Nous Choisissons L'Europe": EU's Economic Development and Current Challenges

Clara Volintiru and Gabriela Drăgan

European Imbalances: The Sound and the Fury . . . . . . . . . . . . . . 73

Jérôme Creel

Unable to Stop Inequality from Rising: Evidence from Romania . . . . . .

Paul Dobrescu and Flavia Durach

Part II Challenges and Opportunities for Development in the Post-Crisis Period

The East-West Divide in the European Union: A Development Divide Reframed as a Political One

Alina Bârgăoanu, Raluca Buturoiu, and Flavia Durach 
New Frontiers in Sovereign Wealth Fund Capitalization . . . . . . . . . . . 119 Juergen Braunstein and Asim Ali

The Impact of Macroeconomic Factors on FDI Attractiveness: Romania, Slovakia and Greece in Comparison . . . . . . . . . . . . . . . . . 133 Kalliopi Kasapi, Andriana Lampou, George Economakis, George Androulakis, and Ioannis Zisimopoulos

Health Care and Migration: What Data Can Tell Us of the Hard-to-Measure Impact of Migrants on the European Health Systems

Guidi Caterina Francesca and Alessandro Petretto

The Multiple Impact of Education Gaps in Romania

Diana-Maria Cismaru and Nicoleta Corbu

Europeanization in the Making: Perceptions of the Economic Effects of European Integration in Romania .

Florența Toader and Loredana Radu

Correction to: Health Care and Migration: What Data Can Tell Us of the Hard-to-Measure Impact of Migrants on the European Health Systems .

Guidi Caterina Francesca and Alessandro Petretto 


\section{List of Contributors}

Asim Ali The Fletcher Network for Sovereign Wealth and Global Capital, The Fletcher School of Law and Diplomacy, Tufts University, Medford, MA, USA

George Androulakis University of Patras, Patras, Greece

Alina Bârgăoanu National University of Political Studies and Public Administration, Bucharest, Romania

Juergen Braunstein Belfer Center for Science and International Affairs, Harvard Kennedy School, Cambridge, MA, USA

Anne L. Buffardi Overseas Development Institute (ODI), London, UK

Raluca Buturoiu National University of Political Studies and Public Administration, Bucharest, Romania

Diana-Maria Cismaru National University of Political Studies and Public Administration, Bucharest, Romania

Nicoleta Corbu National University of Political Studies and Public Administration, Bucharest, Romania

Jérôme Creel Observatoire français des conjonctures économiques (OFCE, Sciences Po), Paris, France

Paul Dobrescu National University of Political Studies and Public Administration, Bucharest, Romania

Gabriela Drăgan Bucharest University of Economic Studies, Bucharest, Romania European Institute of Romania, Bucharest, Romania

Flavia Durach National University of Political Studies and Public Administration, Bucharest, Romania 
George Economakis University of Patras, Patras, Greece

Ian Goldin Oxford Martin School, University of Oxford, Oxford, UK

Guidi Caterina Francesca European University Institute, Florence, Italy

Simon Hearn Overseas Development Institute (ODI), London, UK

Kalliopi Kasapi University of Patras, Patras, Greece

Andriana Lampou University of Patras, Patras, Greece

Tiina Pasanen Overseas Development Institute (ODI), London, UK

Cristian Păun Bucharest University of Economic Studies, Bucharest, Romania

Alessandro Petretto University of Florence, Florence, Italy

Florina Pînzaru National University of Political Studies and Public Administration, Bucharest, Romania

Loredana Radu National University of Political Studies and Public Administration, Bucharest, Romania

Florența Toader National University of Political Studies and Public Administration, Bucharest, Romania

Clara Volintiru Bucharest University of Economic Studies, Bucharest, Romania Ioannis Zisimopoulos University of Patras, Patras, Greece 


\section{Part I: \\ Envisaging Development in the Contemporary Society: Theory and Public Debates}




\title{
Introduction
}

\author{
Paul Dobrescu
}

\section{Why Development?}

Following a repetitive pattern, the world gets closer then drifts away from the complex issue of development. Development as a process is a constant presence in our lives; nevertheless, the debate surrounding it—especially with regard to its intensity and quality - is more or less articulate. How did different theories and models guide development? Looking at this topic 30 years after the end of the Cold War allows us to identify three distinct periods. The first one ranges from the end of the Cold War to the brink of the 2008-2009 economic crisis, the second covers the next decade of slow recovery, while the third, the one we are currently experiencing, is the least studied and understood of all. Before detailing these time intervals, we need to stress a fundamental fact: during the whole timespan of 30 years, development took place within the more general context of globalization, a setting dramatically different than any other in history.

The first period is characterized by two important processes. First, it was driven by an idealized perspective on the relationship between development and globalization. We owe to Dani Rodrik the most drastic analysis of this vision, expressed by the Washington Consensus. ${ }^{1}$ In his book (Rodrik 2011), the American professor

\footnotetext{
This chapter has been prepared with financial support granted in the project "State of the Nation. Designing an innovative instrument for evidence-based policy-making" (SIPOCA 11, MySMIS 118305), which is co-financed by the European Social Fund through the Operational Programme Administrative Capacity 2014-2020.

${ }^{1}$ The term itself was first used in 1989 by John Williamson to refer to the set of measures designed for Latin American countries in their path towards modernisation and reform. The ideological connotations of the term emerged later, when it became the go-to expression to describe a more
}

\footnotetext{
P. Dobrescu $(\bowtie)$

National University of Political Studies and Public Administration, Bucharest, Romania

e-mail: paul.dobrescu@comunicare.ro
} 
makes a poignant criticism of the belief that globalization will help underdeveloped nations escape poverty:

The Washington Consensus derived its appeal from a simple narrative about the power of globalization to lift developing nations out of poverty. But rather than promote the mixed, pragmatic strategies that China and others had employed in order to develop domestic industrial capabilities, advocates of this narrative stressed the role of openness to the global economy...Let these countries (poor countries-editor's note) open themselves up to international trade and investment and a rising tide of trade will pull them up from poverty.

This sugar-coated view induced the false impression that no particular actions needed to be taken and thus encouraged passive attitudes. There is no need for agitation; rest assured that globalization forces are working on your behalf. It seemed that no great efforts were required for development to take place. One only needed to wait patiently until globalization process spilled their abundance over to the national communities. Under the strong impression of these beliefs, development was blatantly ignored as an issue for debate, being replaced by other sources of concern, such as modernization, dependence, Marxism, critical theory, and multiculturalism.

The second process characteristic of this period is the rise of the emerging economies, the countries from Eastern Asia, especially China. In the words of Jonathan Fenby $(2017,1)$, "China is the main beneficiary of globalization". His words were confirmed by other experts as well. For instance, Eduard Luce $(2017,21)$ pointed out that

In 1978, China had less than 1 percent of global trade and in 2013, it had become the world's leading trading nation with almost a quarter of its annual flows. As recently as the turn of the twenty-first century, the US accounted for almost three times as much global trade as China... Nothing on this scale or speed has been witnessed before in history.

How can we explain this historic progress? For the purposes of this introduction, we will emphasize one aspect in particular. In the case of China, openness towards international affairs was doubled by an internal response, a strategy to maintain a balance between the market and governance, to offer the state leverage to respond to globalization flows, to anticipate world-wide phenomena by enforcing a long-term unitary vision (the so-called long-termism). Although we cannot argue that the delicate balance between markets and governance was deciphered and put into practice for good, many studies and analyses draw attention to China's excessive authoritarian tendencies and the prevalence of state over markets. Nevertheless, what we must reflect on from China's experience is its continuous effort to decipher and balance these two fundamental agents of development. The majority of the developed states failed to make progress in this regard, placing the emphasis on markets to the detriment of the state and on the need to intensify globalization. The relationship

general orientation towards a strongly market-based approach (sometimes described as market fundamentalism or neoliberalism). 
between the state and the markets, as fundamental for development as it may be, suffered from a one-sided, naïve, narrow approach (short-termism).

The second stage includes the crisis and post-crisis period. The most delicate problem here is the economic legacy of the crisis, especially the massive indebtedness of the developed states, which made recovery a slow and painful process.

We owe the most adequate depiction of this context to Christine Lagarde, managing director of IMF. Talking about "the dynamic role of emerging countries", she emphasized that "these countries helped pull the global economy back from the brink of another Great Depression a few years ago. They have accounted for almost $80 \%$ of global growth over the past 5 years. They now generate more than half of global output" (Lagarde 2015a).

How did the emerging economies manage to pull their developed counterparts from the brink of disaster? One explanation resides in their impressive rate of growth in the pre-crisis period, ${ }^{2}$ one that raised questions and concerns within the developed world. The speed of evolution and growth expresses the vitality of an organism, and the emergent economies' impressive speed of development (before, during and after the crisis) should make the developed countries question their ways.

Lastly, we need to mention another warning sign, the rise of social inequality, a phenomenon that worries the IMF director to the greatest extent. Inequality is a legacy from the pre-crisis period, one that is becoming more severe in the aftermath of the crisis. Inequality was subject to thorough research by Thomas Piketty and Branko Milanovici, and is a constant preoccupation for world leaders such as Barack Obama and Pope Francis. Since the leader of an international financial institution, such as C. Lagarde, chooses to draw public attention to the phenomenon of inequality, it is easy to assume that it threatens not only the social balance but economic growth as well. "Why is this relevant right now? Because the theme of growing and excessive inequality is not only back in the headlines, it has also become a problem for economic growth and development" (Lagarde 2015b).

The third period, unfolding today, provides a picture in reverse of the first one. The exaggerated perception of the importance of globalization has been substituted by an opposite excess of nationalism, statism, and authoritarianism. When Jan Bremmer (2012) published his work, Every Nation for Itself, the perspective seemed rather remote. A Short 4 years later, it found its materialization in President Trump's formula "America first", which is becoming state policy for the first world power.

Renowned political leaders and experts who supported globalization are now reconsidering their position. Lawrence Summer (2016) illustrates this new prevalent approach: "Reflex internationalism needs to give way to responsible nationalism or else we will only see more distressing referendums and populist demagogues contending for high office". The shift is so radical that Xavier Solana (2017)

\footnotetext{
${ }^{2}$ See in this respect Paul Dobrescu (Dobrescu 2017, 4): "In 2007, for instance, China's growth rate was $14.2 \%$, India's $10.1 \%$, Russia's $8.5 \%$ and Brazil's $6.1 \%$. At the beginning of the decade, the emerging countries' GDP share in the world output was 38\%; in 2013, this share was $50 \%$ (measured at PPP rate)".
} 
warns that "If all countries put their own interests first, paying no heed to others, competition will quickly overwhelm common interests. If nobody is ever willing to yield, we will all lose".

It is the starting point of a genuine race for development, one that involves every country on the globe. The main feature of this period is that development is driven by very precise objectives. These objectives stem from the new digital revolution and the unimaginable opportunities it entails. Referring to the technology race between the US and China, Kevin Rudd, former prime-minister of Australia, as quoted by Crabtree (2018), states that "There is an undeclared Cold War underway now in the IT sector". He continues by arguing that this conflict is more important than any trade war, more important than North Korea, and even than the conflict over the South China Sea.

Many experts emphasize that the new revolution will lead to "tectonic shifts" not only in the tech area but in management, prognosis, publicity, and so on. The flagship of this revolution is artificial intelligence. Vladimir Putin (Vincent 2017) anticipated its impact with the following words: "Artificial intelligence is the future... Whoever becomes the leader in this sphere will become the ruler of the world". What is certain is that the digital revolution found many were not ready to face it.

The world itself seems to be unprepared. At this point we must emphasize an aspect of great interest to us. While in the national public spheres we may discuss in detail many economic issues, we hesitate to acknowledge the real threat for the developed world: its political division. Development is the top priority, the number one project to be undertaken by a society. The fundamental impact the digital revolution is exerting on development is taking place in a context of irreconcilable differences between national political factions. These sides refuse to acknowledge each other's legitimacy as a partner, and to open to dialogue, to agree on national priorities. They fail to embrace a common project on behalf of their nation.

The most touching description of the importance of development that we read in recent years is authored by Ian Goldin (2016): "Development is not simply or mainly about the lives of others. It is about ourselves and what we care about. Development is about who we are and our collective future". The life of a nation can be analyzed from many perspectives. The way in which it has managed to foster its own development is fundamental. Nothing else is more comprehensive and significant. Development accounts for what a nation is, and intends to become. That is why development is the genuine and enduring brand of a country.

The three periods described above characterize the evolution of the developed world in general, and Central and Eastern Europe (CEE) in particular. The states in the region felt the changes brought by the three stages with greater intensity as they overlapped with their own deep structural reforms after the fall of communism. The economic crisis reached CEE states when they were more vulnerable that their western counterparts. Economic and social effects were more intense as well, resulting in growing public discontent and the radicalization of the public opinion in recent years. 
The third stage of development, according to our classification, finds CEE emerged in an anxious quest for development. The first technological revolution of the nineteenth century fueled the Divergence Era, when Europe grew to be the undisputed leader of the developed world. The rose of the emerging economies led to an Age of Convergence (Baldwin 2016), when development gaps between countries and regions decreased. It is our intuition that the large-scale proportions of the new digital revolution will make divergence a reality once again. The hierarchies of this era will depend on the capability of states to take advantage of the limitless possibilities offered by digitalization. The goal of CEE should be to become part of the cluster of states wise enough to rise to the potential this age has to offer. For all the reasons above, we chose to focus this volume on the fundamental topic of development, especially since many analyses led to the conclusion that the EU is not among the leaders of change at this point.

Against this backdrop, the volume Development in Turbulent Times. The Many Faces of Inequality within Europe explores the theoretical and empirical challenges related to the concepts of development, progress, and assessment of national performances. The contributors reflect upon pressing issues in the field and question how existing models of development can be adapted to fit the current challenges inside the European Union. The economic crisis, whose effects are still persistent today, led to reshaping the relationships between development, growth, poverty, and inequality inside and outside the European Union. In this context, the goal of our endeavor is to gather fresh theoretical analyses and empirical studies in the pages of a unitary volume to serve scholars in the field, policy makers, and the public.

We investigate the trends most likely to impact the European Union's medium and long-term development, and discuss the most suitable models for the EU and for its member states. A secondary focus is related to the methodological challenges for the research field, such as the difficulties in selecting the proper indicators, and measuring them consistently. Thirdly, we are preoccupied with the "soft" aspects of globalization and development, meaning the communication flow established between all stakeholders in the process. From a geographical standpoint, the focus of the volume is on the European Union, and especially the under-researched area of Central and Eastern Europe.

The structure of the book is two-fold. The first part, Envisaging Development in the Contemporary Society: Theory and Public Debates, includes contributions that revisit, from a theoretical and/or empirical standpoint, the main theories in the field, taking into consideration current crises as well as the changing patterns of globalization. This section contributes to the discussion of fundamental concepts such as development or underdevelopment, and the relationship between development and other process (i.e. economic growth; inequality, poverty). Contributions under this section also reflect upon the challenges in measuring development and progress.

The opening chapter, authored by Ian Goldin, Oxford University Professor of Globalisation and Development, questions why countries around the globe evolve very differently, that is, why some develop whereas other remain poor. By combining the historical overview of the developmental processes with insights from the academic literature, the author identifies some factors that shape the path towards 
development, ranging from natural resource endowments, geography, history, and culture to policies and the functioning of democracy, to name a few. Lastly, the contribution considers the role of businesses, governments and individuals everywhere in shaping a common sustainable future for development.

If Ian Goldin is concerned with the factors that favor or impede development, the authors of the second chapter, Anne Buffardi, Tiina Pasanen, and Simon Hearn, are more focused on how to accurately assess national progress in this regard. They explore four dimensions of development that are currently difficult to measure: abstract, multi-dimensional concepts, processes and issues; unpredictable changes in the general setting; uncertain pathways of change; and multi-layer implementing structures.

The last three contributions to this section are dedicated to the EU's current challenges for ensuring economic development and finding fiscal balance. As such, they provide a locus for debate on the specific, post-crisis applicability of developmental theories. Florina Pînzaru and Cristian Păun take Romania's case as an example of how development must not be taken for granted as a result of European integration. Given that Romania is currently lagging behind in many areas, the authors draw valuable conclusions on what sound policies for a systemic change to the economy should be. Clara Volintiru and Gabriela Drăgan also discuss inequalities between EU member states in the next chapter, by looking at them through the lenses of international trade. There are significant discrepancies in this regard between EU states, some of them being excessively reliant on the single market instead of opening up, as a whole, to the globalization flows. Further enriching this debate on European imbalances, Jérôme Creel envisages the Eurozone crisis as one of the most severe barriers to the EU's development. He makes a critical inventory of the many explanations for the Eurozone's growing imbalances and advances an unitary explanation to understand the whole crisis landscape. Against this backdrop, the contributor discusses the already implemented reforms within the $\mathrm{EU}$, the current agenda for reform, and other proposals to stimulate future development.

The second part of the volume, Challenges and Opportunities for Development in the Post-Crisis Period, is dedicated to a number of empirical studies on the most pressing contemporary issues in the area of sustainable development. The contributions cover the most important domains for any given society: economy and financial markets, education, health, demographic trends, life satisfaction, and the results of European integration. The elusive realm of public opinion is also considered. The authors identify both the challenges and opportunities for progress in the turbulent times of the present, thus contributing to the public debate on development.

Under this topic, Paul Dobrescu and Flavia Durach take a look at the different perspectives on inequality and its evolution in the post-crisis period. The authors investigate the main theories on inequality within and between nations as well as the public perceptions regarding this phenomenon. The empirical contribution of this chapter consists of measuring through quantitative indicators the different faces of inequality within Romania, concluding with the country's ranking within Central and Eastern Europe. In short, despite economic growth, there is puzzling 
evidence that inequalities have become more severe in Romania. The conclusions encourage the reader to meditate on how to achieve progress without sacrificing equity.

In the same vein, the following chapter looks at the inequalities within Europe from another angle, namely, the East-West developmental divide. The authors, Alina Bârgăoanu, Raluca Buturoiu, and Flavia Durach, argue that this centuries-old divide is currently making a comeback, fueled by persistent differences in the level of development of the old (Western) member states, and the new (CEE) member states. The sobering realization stemming from this analysis is that the acknowledgement of this development gap is the only way to avoid one of the EU's greatest vulnerabilities in the future.

The following four chapters have a very specific focus, each narrowing the discussion down to specific issues that may ensure genuine progress for the European nations or, by contrast, raise longstanding barriers in their path. Juergen Braunstein and Asim Ali look at new sources for Sovereign Wealth Funds, especially by countries that cannot rely on oil wealth or significant export surpluses. New alternative funding sources can become a solution to meet long-term financial and socio-development objectives. As the chapter highlights-through four examples (Bangladesh, Armenia, Indonesia, and Turkey), these funds are increasingly integrated into the national strategies for economic development. The chapter may help practitioners identify creative ways of leveraging national assets in the pursuit of development.

Next, Kalliopi Kasapi, Andriana Lampou, George Economakis, George Androulakis, and Ioannis Zisimopoulos evaluate another main source of economic development: foreign direct investments. Their objective is to discuss the key macroeconomic factors that may affect inward FDI in Romania, Slovakia and Greece in the context of European integration. The authors note the downgrading effect of Europeanisation on FDI attractiveness, and advance some tailored-made explanations in the case of each state.

The tenth chapter of the volume turns to a topic of great interest at the moment: the connection between healthcare and migration as a key challenge for modern welfare societies. Since the human factor is the most important driver of development, we welcome this contribution focusing on the well-being of a very disadvantaged category: migrants. The authors, Caterina Guidi and Alessandro Petretto, discuss the differences in access and use of health systems by intra-EU migrants and migrants from third countries. Measuring the impact of migration on the healthcare systems represents an emerging issue for developed as well as developing countries. They make a compelling argument that sustainable health systems need to tackle social inequalities for the whole population, not only migrants.

The second key factor for the development of human resources, apart from ensuring their access to welfare and the health system, is education. In this regard, Diana Cismaru and Nicoleta Corbu provide empirical evidence of the consequences of education gaps in Romania, and between Romania and other states in Central and Eastern Europe. Their research identifies education gaps in some key areas, with impacts on employability, workforce quality, quality of life, and welfare. Based on 
the empirical findings, the chapter pleads for the implementation of new educational policies in Romania, to increase the enrolment and educational attainment by stimulating the returns of education.

Lastly, public perceptions on development within the EU framework are discussed by Florența Toader and Loredana Radu. Taking Romania, a notably Euroenthusiastic member of the EU as an example, this chapter observes and explains the patterns of EU support in Romania, despite the persistence of developmental gaps after a decade of membership. The results of the analysis challenge the utilitarian approach of EU support (cost-benefits calculations). According to the authors, the strong trust Romanians have in the EU can be more accurately explained by soft predictors, such as pessimism for the state of the national economy and symbolic attachment to the EU.

In their entirety, the chapters gathered within the pages of this volume give answers to as well as ask additional questions about the puzzle of development within the European Union. We explore an old issue (defining and assessing development) in a new context (the post-crisis period). Based on hard and soft data, we argue that hardships did not end in the EU or globally, and that rising inequalities, as well as other challenges, can impede development for many years to come. It is our belief, as well as hope, that this book can be of service to scholars and policy-makers who are willing to reflect upon issues related to evidence-based policymaking and development models.

\section{References}

Baldwin, R. (2016). The great convergence, information, technology and the new globalization. Cambridge: The Belknap Press of Harvard University Press.

Bremmer, J. (2012). Every nation for itself, winners and losers in a G-Zero world. London: Penguin.

Crabtree, J. (2018). There's an 'undeclared new Cold War' between the US and China-and it's in tech, Australia ex-leader says. CNBC. Accessed September 24, 2018, from https://www.cnbc. com/2018/04/30/us-and-china-in-a-cold-war-over-tech-australia-rudd-says.html

Dobrescu, P. (2017). The century of the emerging world, development with a vengeance. Newcastle upon Tyne: Cambridge Scholars Publishing.

Fenby, J. (2017). Will China dominate the 21st century? (2nd ed.). Cambridge: Wiley \& Sons.

Goldin, I. (2016). The pursuit of development, economic growth, social change, and ideas. Oxford: Oxford University Press.

Lagarde, C. (2015a, October 9). Brothers and sisters, there is much to do. IMF-World Bank Annual Meetings Plenary. Accessed September 24, 2018, from https://www.imf.org/en/News/Articles/ 2015/09/28/04/53/sp100915

Lagarde, C. (2015b). Lifting the small boats. Address at Grandes Conferences Catholiques. Accessed September 15, 2018, from http://www.imf.org/en/News/Articles/2015/09/28/04/53/ sp061715

Luce, E. (2017). The retreat of western liberalism. London: Little Brown.

Rodrik, D. (2011). The globalization paradox: Why global markets, states, and democracy can't coexist. Oxford: Oxford University Press. 
Solana, J. (2017, February 24). European Union First. Social Europe. Accessed September 15, 2018, from https://www.socialeurope.eu/2017/02/european-union-first/

Summer, L. (2016, July 10). Voters deserve responsible nationalism not reflex globalism. Financial Times. Accessed July 21, 2018, from https://www.ft.com/content/15598db8-4456-11e6-9b66$0712 \mathrm{~b} 3873 \mathrm{ae} 1$

Vincent, J. (2017). Putin says the nation that leads in AI 'will be the ruler of the world'. The Verge. Accessed October 1, 2018, from https://www.theverge.com/2017/9/4/16251226/russia-ai-putinrule-the-world

Open Access This chapter is licensed under the terms of the Creative Commons Attribution 4.0 International License (http://creativecommons.org/licenses/by/4.0/), which permits use, sharing, adaptation, distribution and reproduction in any medium or format, as long as you give appropriate credit to the original author(s) and the source, provide a link to the Creative Commons licence and indicate if changes were made.

The images or other third party material in this chapter are included in the chapter's Creative Commons licence, unless indicated otherwise in a credit line to the material. If material is not included in the chapter's Creative Commons licence and your intended use is not permitted by statutory regulation or exceeds the permitted use, you will need to obtain permission directly from the copyright holder. 


\title{
Why Do Some Countries Develop and Others Not?
}

\author{
Ian Goldin
}

\section{Introduction}

How individuals and societies develop over time is a key question for global citizens. Too many people in the world still live in extreme poverty. About one billion people live on less than $\$ 1.25$ a day (the World Bank's definition of extreme or absolute poverty) while about 2.2 billion people live on less than $\$ 2$ per day. What can be done about this?

Development Studies as an academic discipline is relatively new, but the questions being asked are not-philosophers have puzzled over them for millennia. There are many definitions of development and the concept itself has evolved rapidly over recent decades. To develop is to grow, which many economists and policymakers have taken to mean economic growth. Yet development is not confined to economic growth. Development is no longer the preserve of economists and the subject itself has enjoyed rapid evolution to become the subject of interdisciplinary scholarship drawing on politics, sociology, psychology, history, geography, anthropology, medicine and many other disciplines.

This chapter draws extensively on Ian Goldin, The Pursuit of Development: Economic Growth, Social Change and Ideas, Oxford University Press, 2017. Readers are referred to the book for the full references and for recommendations and further reading.

\footnotetext{
I. Goldin ( $\square)$

Oxford Martin School, University of Oxford, Oxford, UK

e-mail: ian.goldin@oxfordmartin.ox.ac.uk
} 


\section{Why Do Some Countries Develop and Others Not?}

A hundred years ago, Argentina was amongst the seven wealthiest nations in the world, but now ranks 43rd in terms of real per capita income. In 1950, Ghana's per capita income was higher than that of South Korea; now South Korean people are more than 11 times wealthier than the citizens of Ghana. Meanwhile, more than 20 failed states and over a billion people have seen little progress in development in recent decades, whilst over three billion people have seen remarkable improvements in health, education and incomes.

Within countries, the contrast is even greater than between countries. Extraordinary achievements enjoyed by some occur alongside both the absolute and relative deprivation of others. What is true for advanced societies, such as the United Kingdom and United States, is even more so in most, but not all, developing countries.

Many factors accounting for the successes and failures in the extreme unevenness of development outcomes. There is an extensive literature which seeks to explain outcomes on the basis of natural resource endowments, geography, history, cultural or other.

Overall, the evidence points to divergence-rather than convergence-in recent decades, although there is some variation amongst geographical sub-groupings, with a set of Southeast Asian economies (the "tigers") displaying evidence of convergence. In 1993 Parente and Prescott studied 102 countries over the period from 1960 to 1985 . They found that disparities in wealth between rich and poor countries persist, despite an average increase in incomes, although there is some evidence of dramatic divergence within Asia, which is consistent with some South East Asian economies-Japan, Taiwan, South Korea and Thailand-catching up with the West. $\mathrm{Li}$ and $\mathrm{Xu}$, have highlighted the extent to which the real incomes of seven South East Asian economies have grown 3.5 times (Malaysia) to 7.6 times (China) faster than the United States and the G10 economies for the period from 1970 to 2010.

The World Bank attributed the "East Asian Miracle" to sound macroeconomic policies with limited deficits and low debt, high rates of savings and investment, universal primary and secondary education, low taxation of agriculture, export promotion, promotion of selective industries, a technocratic civil service, and authoritative leaders. However, the Bank failed to highlight the extent to which the achievements came at the expense of civil liberties, and that far from being free markets the governments concerned subjugated the market (and suppressed organised labour), often with the generous support of the United States and other development and military aid programmes, following the Korean and Vietnam Wars.

Others have argued that South East Asia's relative success had more to do with pursuing strategic rather than "close" forms of integration with the world economy. In other words instead of opting for unbridled economic liberalisation in line with the Neo-Classical market friendly approach to development, countries such as 
Japan, South Korea and Taiwan selectively intervened in the economy in an effort to ensure that markets flourished. Several well-known commentators including Ajit Singh, Alice Amsden and Robert Wade have documented the full range of measures adopted by these countries, which appear to constitute a purposive and comprehensive industrial policy. These measures include the use of long-term credit (at negative real interest rates), the heavy subsidization and coercion of exports, the strict control of multinational investment and foreign equity ownership of industry (in the case of Korea), highly active technology policies, and the promotion of large scale conglomerates together with restrictions on the entry and exit of firms in key industrial sectors. The relative contribution of selective forms of intervention on the one hand, and market friendly liberalisation and export orientation on the other, to the success of the South East Asian economies remains a subject of debate.

\subsection{Poverty and Inequality}

Income measures are only one dimension of poverty. Other indicators, including those relating to infant and child mortality, illiteracy, infectious disease, malnutrition and schooling are also important. A number of countries have made extraordinary strides in overcoming poverty. In some, progress has been across the board, whereas others have managed to achieve very significant progress on one dimension but fallen back on others. With similar levels of average per capita incomes, in Bangladesh average life expectancy is 71, whereas in Zimbabwe it is 60 and in Tanzania it is 61 .

Inequality between countries and within countries requires an analysis which goes beyond the headline economic indicators. While average per capita incomes are growing in most countries, inequality is also growing almost everywhere. The world's richest $20 \%$ of people account for three quarters of global income and consume about $80 \%$ of global resources, while the world's poorest $20 \%$ consume well under $2 \%$ of global resources. Where poor people are is also changing. Twenty years ago over $90 \%$ of the poor lived in low income countries; today approximately three quarters of the world's estimated one billion people living on less than $\$ 1.25$ per day live in middle income countries.

\subsection{Explaining Different Development Trajectories}

Every country is unique. Yet it is still possible to identify a range of factors that affect development trajectories. A number of economic historians have shown that patterns of resource endowments can reinforce inequalities and favour elites, with this in turn leading to "capture" and predatory institutional development. The resource curse has been examined by Paul Collier (2007), Jeffrey Frankel, and 
others, who have shown that ample endowments of natural resources may be linked with stunted institutional development, particularly in the case of mining and oil. In mining and oil multinational or local investors have often operated behind a veil of secrecy. The awarding of contracts for extractive industries provides a source of power and patronage to corrupt leaders. Evidence of corruption by international firms who have made offshore payments through international banks provides a clear example of how both advanced and developing countries have a responsibility to clamp down on corrupt practices, not least in mitigating the risks associated with the extraction of natural resources.

For the classical and neo-classical economists, as well as their critics on the Left, natural and human resource endowments were a key determinant of trade and market integration. While the former group argued that revealed comparative advantage would lead to development, the critics argued the opposite, concluding that it would lead to more uneven development. Both groups saw international trade as a critical determinant of growth, explaining the convergence (or divergence) of growth rates and global incomes, with Dani Rodrik, Jeffrey Sachs and Andrew Warner, Jeffrey Frankel and David Romer, and David Dollar and Aart Kray contributing conflicting evidence of the relationship between trade and development.

Jared Diamond, Jeffrey Sachs and others explain development outcomes by providing geographical explanations. They argue that moderate advantages or disadvantages in geography can lead to big differences in long-term economic performance and that poor economic performance can be explained in terms of the "bad geography" theses. Geography is thought to affect growth in at least four ways. Firstly, economies with coastal regions, and easy access to sea trade, or nearby large markets have lower transport costs and are likely to outperform economies that are distant and landlocked. Secondly, tropical climatic zones face a higher incidence of infectious diseases, and malaria, bilharzia and other parasitic infections which hold back economic performance by reducing worker productivity. For example, in 2015, malaria caused an estimated 438,000 deaths mostly among sub-Saharan African children. In addition, a high incidence of disease can raise fertility rates and add to the demographic burden of a country. Thirdly, geography affects agricultural productivity in a variety of ways. Grains are less productive in tropical zones, with a hectare of land in the tropics yielding on average around one-third of the yield in temperate zones. Fragile soils in the tropics and extreme weather are part of the explanation, as is the higher incidence of pests and parasites which damage crops and livestock. Fourthly, as the tropical regions have lower incomes and crop values, agri-businesses invest less in tropical regions, and national research institutions are similarly poorer. The implication is that international agencies, such as the Consultative Group for International Agricultural Research (CGIAR) - which is donor funded-have a particular responsibility to raise the output of tropical agriculture. A similar point can be made with respect to tropical diseases, with low purchasing power holding back development of drugs to combat many of the most significant tropical diseases.

William Easterly and Ross Levine as well as Rodrik and others, have argued that the impact of geography is regulated through institutions and that good governance 
and institutions can provide the solution to bad geography. For example, good governments can build efficient roads and irrigation systems, and invest in vital infrastructure as well as enforce legal contracts and curb corruption. In short, good governance minimises uncertainty and transaction costs and can overcome bad geography. However, bad governance does not. For Easterly there are too many "Ifs, buts and exceptions" to Sachs' bad geography thesis. Destructive governments rather than destructive geography may also explain the poverty of nations.

Rodrik and others argue that it is the quality of institutions - property rights and the rule of law - that ultimately matters. Once the quality of institutions is taken into account (statistically "controlled for" using econometric techniques), the effect of geography on economic development fades away. However, as Rodrik notes, the policy implications associated with the "institutions rule" thesis are difficult to discern and likely to vary according to context. This in part is because institutions are partly endogenous and co-evolve with economic performance. As countries become better off they have the capacity to invest in more education and skills and better institutions, which in turn makes them better off.

For Daron Acemoglu, Smon Johnson and James Robinson, the development of institutions which facilitate or frustrate development, are rooted in colonialism and history. These authors argue that contemporary patterns of development are largely the result of different forms of colonialism and the manner in which particular countries were, or were not, settled over the past 500 years. The purposes and nature of colonial rule and settlement shaped institutions which have had lasting impacts. In countries with high levels of disease, high population density, and lots of resources, colonial powers typically set up "extractive states" with limited property rights and few checks against government power in order to transfer resources to colonizers, such as was the case in the Belgium Congo. In countries with low levels of disease and low population density, but also less easily extractable resources, settlement was more desirable and colonial powers attempted to replicate European institutions-strong property rights and checks on the abuse of power-and made an effort to develop agriculture and industry as was the case in Canada, United States, Australia and New Zealand. According to this thesis, the legacy of colonialism led to an institutional reversal that made poor countries rich, and rich countries poor.

Although we may well live in a world shaped by natural resource endowments, geography, history and institutions, politics and power can still play a decisive role in terms of driving economic performance and determining vulnerability to poverty. In Amartya Sen's Poverty and Famines, he showed that political power and rules that are embedded in ownership and exchange determine whether people are malnourished or have adequate food, and that malnourishment is not mainly the result of inadequate food supply. Sen shows how droughts in North Africa, India and China in the nineteenth and Twentieth centuries were catastrophic for social and political reasons, with power relations, not agricultural outcomes, leading to widespread starvation and destruction of the peasantry. In 1979, Colin Bundy, in The Rise and Fall of the South African Peasantry was among a new wave of historians who argued that colonialism led to the deliberate collapse of a previously thriving domestic 
economy. In 1997, Jared Diamond's, Blood, Germs and Steel, while emphasising the importance of geography and history, showed how technology, culture, disease and other factors led to the destruction of native American and other previously thriving communities. These authors, echoing Marx, highlighted the extent to which development can be a very bloody business, even if the longer term consequences may be to bludgeon societies into a new era.

If the abuse of power can set development back, what about the counter argument that democracy leads to more rapid and equitable development outcomes? According to Irma Adelman, the long-term factors governing the association between development and democracy include the growth of middle classes, increase in quantity and quality of education, urbanisation (including more infrastructures), the need for participation in development strategies, and the need to manage the psychological and social strains arising from change. Acemoglu, Robinson and others went further in 2014, arguing that democracy does cause growth, and that it has a significant and robust positive effect on GDP. Their results suggest that democracy increases future GDP by encouraging investment, increasing schooling, and inducing economic reforms, improving public good provision, and reducing social unrest. The difficulty of defining democracy, and the weight attached to the non-democracies which have enjoyed very rapid growth, such as China and Singapore, as well as the slowing of growth and paralysis in decision making in many parts of Latin America, Europe and other democratic regions means that the academic jury remains divided on the relationship between development and democracy.

\section{What Can Be Done to Accelerate Development?}

Peace and stability are essential for development as conflict and war leads to development in reverse, destroying not only lives, but also the infrastructure and cohesion which are fundamental to development. Literacy and education-and particularly the role of education for women-are vital, not least in overcoming gender inequities. The literature shows that these are key contributors to declining fertility and improved family nutrition and health. Infrastructure investments, particularly in clean water, sewerage and electricity, as well as rural roads, are essential for growth and investment, as they are for achieving improved health outcomes. The rule of law and the establishment of a level playing field, through competition and regulatory policies are vital for ensuring that the private sector is allowed to flourish. The capturing of the market by monopolies or small elites, often with the connivance of politicians or civil servants, is shown to lead to the skewing of development and growing inequality.

No country is an island economically and the way that countries engage with the rest of the world is a key determinant of their development outcomes. The increasing integration of the world, in terms of financial, trade, aid and other economic flows, as well as health, educational, scientific and other opportunities requires an increasingly sophisticated policy capability. So too does the management of the risks 
associated with increased integration into the global community. The threat posed by pandemics, cyberattacks, financial crises and climate change and other global developments could derail the best laid development efforts. Systemic risks have a particularly negative impact on development outcomes, and without exception tend to have negative distributional consequences. The existence of effective policies, or their absence, shapes the harvesting of the upside opportunities and mitigation of the risks.

\subsection{Literacy, Education and Health}

There are both theoretical and empirical reasons for believing that literacy and education are essential for economic and social development. The education of girls has served to reduce widespread gender inequalities and has improved the relative position of women in poor countries. The education and empowerment of women has been associated with improvements in a range of development outcomes, and is associated with sharp falls in infant mortality and fertility.

The links between education, health and development are many and varied; in many contexts "all good things" (or "bad things") go together. The demographic transition describes how fertility and mortality rates change over the course of economic and social development. In the early or first phase of development birth rates and mortality rates are high due to poor education, nutrition and healthcare. In such circumstances, characteristic of many developing countries prior to the Second World War, population growth remains low. As living standards, nutrition and public health improve during the second phase of the transition, mortality rates tend to decline. As birth rates remain high, population growth becomes increasingly rapid. Historically, much of Africa, Asia and Latin America experienced this trend during the second half of the twentieth century.

Over half the countries in the world, including many developing countries, have now entered the third stage of demographic transition. This is characterised by improvements in education and health along with changes in technology, including the widespread availability of contraceptives, which give women greater choice. In this stage, urbanisation and greater female participation in the workforce reduces the economic and social benefit of having children and raises the costs. In the fourth stage of the demographic transition, both mortality and birth rates decline to low or stable levels and population growth begins to fall. Many developed countries have passed this stage and face the prospect of zero or negative population growth. As this trend continues, countries experience a rapid decline in fertility, to below replacement level. The combination of rapidly falling fertility and continued increases in life expectancy leads to rapid increases in median ages, with these projected to double in all regions, except for Africa, in the period to 2050. 


\subsection{Gender and Development}

Gender inequalities and unequal power relations skew the development process. In many developing countries women's opportunities for gainful forms of employment are limited to subsistence farming - often without full land ownership rights or access to credit and technology that might alter production relations and female bargaining power. In many societies, women are confined either to secluded forms of home-based production that yield low returns, or to marginal jobs in the informal economy where income is exceptionally low and working conditions are poor. In addition women typically have to endure the "double burden" of employment and domestic work - the latter includes housework, preparing meals, fetching water and wood, and caring for children-amongst many other tasks.

A range of studies over the last four decades have shown that households do not automatically pool their resources, and that who earns and controls income can make a major difference to household well-being. Numerous empirical studies examining the relationship between women's market work, infant feeding practices and child nutrition indicate that the children of mothers with higher incomes are better nourished. In the gold mining industry in Africa for example an increase in women's wage earning opportunities has been shown to be associated with the removal of healthcare barriers, the halving of infant mortality rates—especially for girls—and a reduction in the acceptance rate of domestic violence by $24 \%$.

The distribution of benefits and burdens becomes more equitable when women have a stronger voice and more access to education and employment. Improving women's economic opportunities can prove a highly effective way to reduce poverty and improve women's relative position and that of their children. Ensuring that more women are enrolled in education, can read, write and count, and have appropriate skills for jobs are also likely to improve the overall well-being of households. Steps to tackle restrictive cultural norms and laws regarding women's education, participation in the labour force, ownership of land and other assets, inheritance rights, marriage and freedom to participate in society make important contributions in this regard.

Many of these initiatives are likely to translate into specific sectoral priorities and policies-for example vocational training, access to cheap transport, and access to saving and credit markets. Women are disadvantaged in the credit market as they typically have no collateral. Innovative microfinance schemes have sought to overcome this by providing flexible loans on favourable terms, often requiring no collateral or with zero interest, for investment in small scale productive activities-such as rearing chickens or a goat. The most well-known example is the Grameen Bank, which has been providing finance to poor Bangladeshis since the late 1970s. By 2015 cumulative disbursement of loans exceeded $\$ 16$ billion and the bank had provided loans to over seven million individuals, $97 \%$ of whom are women.

The participation of women in the workplace together with gender differences in pay, promotion and business leadership are important aspects of empowerment. 
Political representation and gender disparities in healthcare and education (often reflecting "boy preference" in many parts of the world) are also key indicators of social progress. Since the introduction of the MDGs in 1990, women in many countries have made progress towards parity with men, although much more still needs to be done. Significant progress has been made in terms of tackling female infant mortality and enabling your girls to attend school, although gross disparities between men and woman persist across the board. Despite some notable progress, so too do practices which fundamentally constrain women, such as female genital mutilation, which affects at least 125 million women in over 29 countries.

Less progress has been made in terms of women's employment in the labour market-especially in Asia where ground has actually been lost over the last 25 years. This may have far reaching implications beyond our concern with fairness and gender justice. A recent speculative study suggests that advancing gender equality in the workplace could add as much as \$12 trillion to global GDP by 2025 (assuming every country in the world could match the performance of its fastest improving neighbour in terms of progress towards gender equality). While the advanced economies have the most to gain, developing countries and regions could expect to benefit from significant increases in income by 2025 including India ( $\$ 0.7$ trillion or $11 \%$ of GDP), Latin America (\$1.1 trillion or 14\% of GDP), China ( $\$ 2.5$ trillion or $12 \%$ of GDP), sub-Saharan Africa ( $\$ 0.3$ trillion or $12 \%$ of GDP), and the Middle East and North Africa (\$0.6 trillion or 11\% of GDP) (amongst other countries and regions).

Knowing that education, health and nutrition, and gender equity—amongst other things - are important for development is only the start. Developing policies to tackle these issues is a major challenge. In many countries, for example, the failure of education systems relate to a lack of quality rather than quantity of resources spent. In India case studies have catalogued a number of issues including poorly trained and qualified teachers, mindless and repetitive learning experiences, lack of books and learning material, poor accountability of teachers and unions, school days without formal activities, and high rates of absenteeism amongst staff and students. Moreover, improving outcomes is more complex than finding money for school fees or budgets for teachers. Issues such as having appropriate clothes for the walk to school or the availability of single sex toilets at school can play a decisive role, especially for girls.

\subsection{Agriculture and Food}

Agriculture provides the main source of income and employment for the $70 \%$ of the world's poor that live in rural areas. The price and availability of food and agricultural products also dramatically shapes the nutrition and potential to purchase staples for the urban poor.

Policies which discriminate against farmers and seek to create cheap urban food by holding down agricultural prices can perversely lead to rising poverty, especially 
where the bulk of the poor are in the countryside. Low agricultural prices depress rural incomes, as well as the production and supply of food and agricultural products. The urban poor are however more politically powerful than the rural poor, not least as they are present in capital cities. An important contributor to the French Revolution of 1789 was the doubling of bread prices, and urban food protests have continued to pose a serious threat to governments.

Whereas in many developing countries farmers are discriminated against through price controls or restrictions on exports, which keep the price of their products artificially low, in many of the more advanced economies, and notably in the United States, European Union and Japan, certain groups of farmers have achieved an extraordinarily protected position. Tariff barriers and quotas which restrict imports, together with production, input subsidies, tax exemptions and other incentives benefit a small group of privileged farmers at the expense of consumers and taxpayers in the advanced economies. This fundamentally undermines the prospects of farmers in developing countries, who are unable to export the products that they are competitive in. It also makes the prices of these products more volatile on global markets, as only a small share of global production is traded so that the international markets become the residual, onto which excess production is dumped.

An added cause of instability is that the concentration of production in particular geographic areas of the United States and Europe increases the impact of weather related risks which exacerbates the instability in world food prices. Because farmers in many developing countries cannot export protected crops, they are compelled to concentrate their production in crops that are not produced in the advanced economies, and produce coffee, cocoa and other solely tropical agricultural commodities. This reduces diversification and leads to excessive specialisation in these commodities, depressing prices and raising the risks associated with monocultures. The levelling of the agricultural playing field, which has been a key objective of the Doha Development Round of Trade Negotiations, which was initiated by the World Trade Organization (WTO) in 2001, remains a key objective of development policy.

\subsection{Infrastructure}

Infrastructure is the basic physical and organisational structures and facilities required for the development of economies and societies. Infrastructure includes water and sanitation, electricity, transport (roads, railways and ports), irrigation and telecommunications. Infrastructure provides the material foundations for development. Investments in infrastructure tend to require very large and indivisible financial outlays and regular maintenance. These investments shape the evolution of cities, markets and economies for generations and lock in particular patterns of urbanisation and water and energy use. Prudent investment in energy and transport infrastructure can have a significant impact on environmental sustainability through ensuring lower emissions, higher efficiency and resilience to climate change. 
Investment in sewerage and sanitation, as well as recycling of water, similarly has a vital role to play in reducing water-use and pollution.

Public private partnerships can play a major role, especially in urban areas and in telecommunications and energy. Project finance and a range of other private investment structures are being used in a growing number of developing countries to encourage private investment in infrastructure. The outcomes have been decidedly mixed. In the United Kingdom, which has a reasonably sophisticated policy environment, public-private partnerships have been found by the National Audit office to provide poor value for money. In developing countries, following the bankruptcies of toll roads in Mexico and water utilities in Argentina, lessons have been learnt and developing countries now account for well over half of the private investments in infrastructure globally. Given infrastructure demands and the shortage of adequate government finance, there is a growing need for private power, telecommunications and other infrastructure investors to finance construction and operations. The mixed experience in recent decades points to the need for caution and the establishment of independent and powerful regulators to protect consumer interests from what can become natural monopolies or oligopolies.

\subsection{Legal Framework and Equity}

Laws serve to shape societies and, in particular, affect the nature of the relationships of citizens to each other and to their governments. Legal frameworks include the "systems of rules and regulations, the norms that infuse them, and the means of adjudicating and enforcing them". The rule of law has shaped development processes through the operation of laws, regulation and enforcement; enabled conditions and capacities necessary to development outcomes; and remained a core development end in itself. Therefore, the rule of law is of fundamental importance to development outcomes as it expresses and enables a society's conception of social and economic justice, and more specifically its attitudes to extreme poverty and deprivation. It also frames wealth, resource and power (re)distribution.

An effective legal and judicial system is an essential component for economic development, as it is for human development and basic civil liberties. Ensuring that decision making and justice are not determined by individual favours or corruption and that all citizens have equal access to the rule of law is vital to overcoming inequality and social exclusion. It is also required for the creation of transparent and well-functioning financial and other markets.

The relationship between the legal system and development is complex. In 1990, Douglas North and others pointed to a high positive correlation between the protection of property rights and long-term economic growth. Critics question whether the protection of property rights is a cause or a consequence of economic development. In this respect several studies have shown that access to legal information and the rule of law can enhance participation and promote socio-economic development by empowering the poor and marginalised, to claim rights, take advantage of economic 
and social opportunities and resist exploitation. The law and the courts can play an important role in defining identity and guaranteeing economic and social opportunities. The rule of law can improve access to service delivery by reallocating rights, privileges, duties and powers. Strengthening legal institutions that prevent violence and crimes that undermine the well-being of citizens promotes development.

Legal institutions that promote accountability and transparency, and curb corruption can similarly facilitate development. Consistent and fair regulation and dispute resolution facilitates the smooth operation of the market system, and reduces the opportunities for corruption, nepotism and rent seeking. The rule of law can also protect the environment and natural resources and promote sustainable development by enshrining workers, social and environmental rights in constitutions and legislation.

\section{The Future of Development}

Over the past 75 years ideas about the responsibility of development have shifted from the colonial and patronising view that poor countries were incapable of developing on their own and required the guidance and help of the rich colonial powers, to a view that each country has a primary responsibility over its own development aims and outcomes and that development cannot be imposed from outside. However, while both simple colonial and Marxist ideas of the interplay of advanced and developing countries are discredited, foreign powers and the international community can still exercise a profoundly positive or negative impact on development. This goes well beyond development aid as international trade, investment, security, environmental and other policies are typically more important. The quantity and quality of aid, the type of aid, as well as its predictability and alignment with national objectives nevertheless can play a vital role in contributing to development outcomes, particularly for low income countries and the least developed economies. Access to appropriate technologies and capacity building helps to lay the foundation for improved livelihoods. So although development is something which countries and citizens must do for themselves, the extent to which the international community is facilitating or frustrating development continues to influence and even at times dramatically shape development trajectories.

The extraordinary progress made in poverty reduction is evidence that development does happen. As is evident in Fig. 1, the number of people living under $\$ 1.25 \mathrm{a}$ day (at 2005 PPP) fell by almost 900 million between 1990 and 2011, even though the population of developing countries increased by over 2 billion over the same period. Much of this decline is attributable to the progress made in China, and to a lesser extent East Asia and India. The greatest development challenge remains in sub-Saharan Africa. We showed earlier that, particularly for the poorest countries, aid remains central to development efforts, but that aid also plays a vital role in other countries and in addressing public goods. 


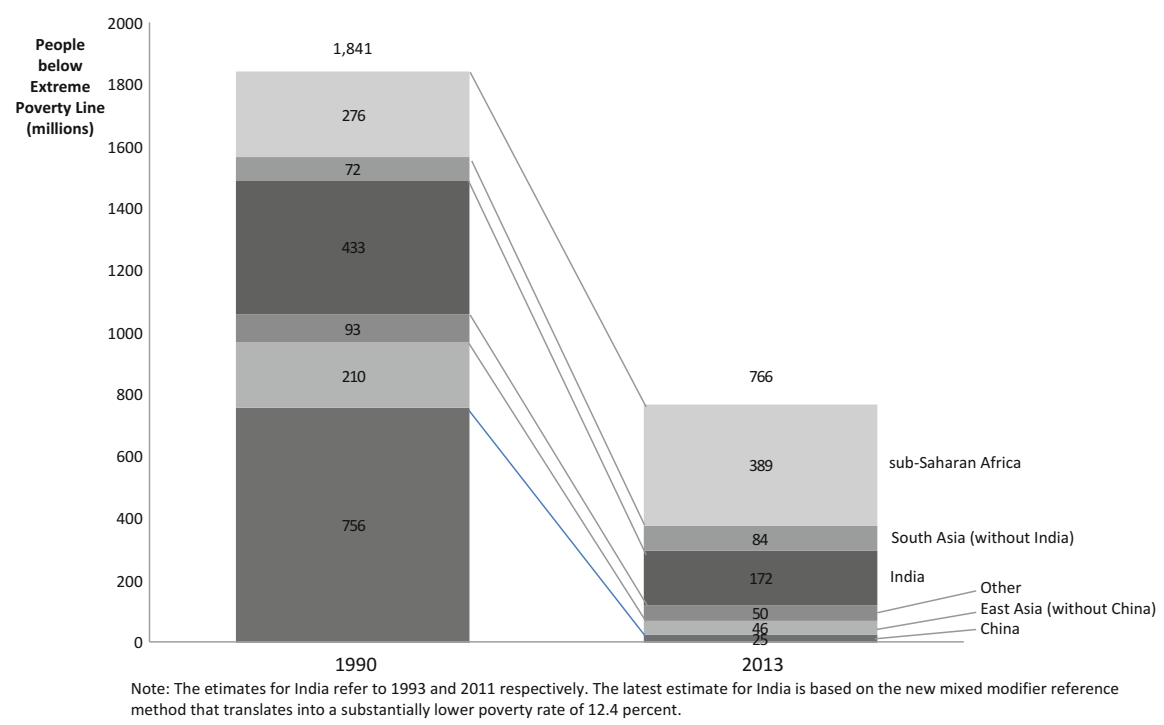

Fig. 1 People living on less than $\$ 1.90$ per day by region (1990-2013). Source: Ian Goldin, Development: A Very Short Introduction, Oxford University Press, 2018. (Reprinted with kind permission by (C) Oxford University Press 2018. All Rights Reserved.)

The latest poverty estimates for 2015 point to a further reduction in the number of people living below the $\$ 1.25$ poverty line, to around 835 million, the vast majority of whom continue to be located in South Asia (310 million) and sub-Saharan Africa (383 million). By 2030 the number of people living below the $\$ 1.25$ poverty line is projected to halve again (to around 411 million), with the vast majority of gains being made in South Asia where 286 million people are expected to escape extreme poverty.

In October 2015, the World Bank introduced a new "extreme poverty" line of $\$ 1.90$ per day at $2011 \mathrm{PPP}$. The new poverty line has implications for the number of people classified as poor and implies re-estimating historical poverty rates (Table 1). The latest headline figure for 2012 - the most recent year for which globally comparable data is available-suggests that close to 900 million people (or 12.8\% of the global population) live in extreme poverty. The majority are located in South Asia and sub-Saharan Africa, and to a lesser extent in South East Asia. Although global income poverty has been reduced dramatically (irrespective of the poverty line adopted), it important to remember that progress on many of the social indicators featured in the MDGs and SDGs has been slower.

It is now widely recognised that while governments must set the stage and invest in infrastructure, health, education and other public goods, the private sector is the engine of growth and job creation.

The coherence of aid and other policies is an important consideration. For example, supporting agricultural systems in developing countries requires not only 
Table 1 Total number and proportion of people below the $\$ 1.90$ poverty line (1990-2015)

\begin{tabular}{l|c|l|l|l|r|l|r|r}
\hline & \multicolumn{4}{|l|}{$\begin{array}{l}\text { Proportion below } \\
\$ 1.90\end{array}$} & \multicolumn{4}{l}{$\begin{array}{l}\text { Millions of people below } \\
\$ 1.90 \text { a day PPP 2011 }\end{array}$} \\
\hline & 1990 & 1999 & 2012 & 2015 & 1990 & 1999 & 2012 & 2015 \\
\hline East Asia and Pacific & 60.6 & 37.5 & 7.2 & 4.1 & 995.5 & 689.4 & 147.2 & 82.6 \\
\hline Europe and Central Asia & 1.9 & 7.8 & 2.1 & 1.7 & 8.8 & 36.8 & 10.1 & 4.4 \\
\hline $\begin{array}{l}\text { Latin America and the } \\
\text { Caribbean }\end{array}$ & 17.8 & 13.9 & 5.6 & 5.6 & 78.2 & 71.1 & 33.7 & 29.7 \\
\hline South Asia & & & & & & & & \\
\hline Sub-Saharan Africa & 50.6 & - & 18.8 & 13.5 & 574.6 & - & 309.2 & 231.3 \\
\hline World & 56.8 & 58.0 & 42.7 & 35.2 & 287.6 & 374.6 & 388.8 & 347.1 \\
\hline
\end{tabular}

Note: The Middle East and North Africa (MENA) is omitted as survey data coverage is too low The available evidence implies a poverty rate of $2.3 \%$ in the MENA region in 2012 and a poverty rate of $41.2 \%$ for South Asia in 1999

$2015=$ projection

investments in rural roads and irrigation, but also support for international research which will provide improved seeds, trade reform which allows access to crops, and actions which will stop the devastating impact of climate change on agricultural systems in many of the poorest countries. As noted earlier, the establishment of a level playing field for trade, and in particular the reduction of the agricultural subsidies and tariff and non-tariff barriers in rich countries that severely discriminates against agricultural development and increase food price instability, would provide a greater impetus for many developing countries than aid. Not all trade is good, and the prevention of small arms trade, toxic waste, slave and sex trafficking and other illicit trade should be curtailed and corruption dealt with decisively. The prevention of transfer pricing and of tax avoidance is important in building a sound revenue base which provides the means for governments to invest in infrastructure and health, education and other systems which provide the foundation for development.

The provision of global public goods, for example by improving the availability, price and effectiveness of vaccinations and drugs, especially against tropical diseases and the treatment of HIV/AIDS, is a similarly important contribution for the international community. The creation of an intellectual property regime that allows for affordable drugs and the encouragement of research on drugs and technologies that foster development, not least in agriculture, is another essential role for the international community.

The international community has a central role to play in the protection and restoration of the global commons, not least with respect to climate change and the environment. The establishment of global security and the implementation of agreements which seek to prevent genocide and facilitate the safe movement and fair treatment of migrants and refugees is another key responsibility of the international community. So too is the prevention of systemic risks. Poor people and poor countries are most vulnerable to all forms of risk, and so international efforts to reduce systemic 
risks which cascade over national borders is another area which requires the coming together of the international community.

Development is a national responsibility, but in an increasingly integrated world the international community has a greater responsibility to help manage the global commons as an increasing share of problems spill over national borders. All countries of the world share a collective responsibility for the planet, but the bigger and more advanced the country, the larger the share of this responsibility that it is capable of shouldering.

\subsection{Our Common Future}

As individuals get wealthier and escape poverty the choices they make increasingly impact on others. The tension between individual choice and collective outcomes is not new, with the study of the management of commons going back at least 500 years. Commons were shared lands, rivers or other natural resources over which citizens had access. In England, the rights of access became defined in common law. Many of these rights were removed in the enclosure movement which in the eighteen century converted most of the common lands into private property.

The tragedy of the commons refers to the overexploitation of common resources. Early examples include the overfishing of rivers, overgrazing of village fields or depletion of underground water. The management of the commons has led to the development of customary and more recently legally enforceable rules and regulations which limit the exploitation of shared resources. In recent decades however, the pressure on common resources, and in particular on the global commons, has grown with population and incomes. The global commons refers to the earth's shared natural resources, and includes the oceans, atmosphere, Polar Regions and outer space.

Development has meant that we are moving from a world of barely 500 million middle class consumers in the 1980 s to a world of over 4 billion middle class consumers in the coming decade. This triumph of development is a cause for celebration. But it provides a source for growing alarm about our ability to cooperate and coexist in a sustainable manner on our beautiful planet. Greater individual choice is for many regarded as a key objective and outcome of development processes. Other outcomes include increasing life expectancy, higher incomes and rising consumption. Development has resulted in rapid population growth-two billion more people over the past 25 years with a further two billion plus expected by 2050 . And globalisation has seen not only more connectivity but also an increase in the global flows of goods and services, with the sourcing of products and services from more distant places. The pressure on scarce resources has never been greater. Nor has the difficulty of managing them.

The result is a sharp rise in the challenge of managing the global commons, coupled with the rise of new collective challenges. Antibiotic resistance is one of 
these new challenges. While it is rational for individuals to take antibiotics to defeat infections, the more that people take antibiotics, the higher the risk of resistance. When combined with the growing use of antibiotics in animals, there is an escalating risk of antibiotic resistance, which would lead to rapid declines in the effectiveness of antibiotics, with dramatically negative consequences on these essential components of modern medicine. Other examples of the tension between our individual choice and collective outcomes include the consumption of tuna and other fish which are threatened with extinction, or our individual use of fossil fuel energy and the resulting collective implications for climate change.

As development raises income and consumption and increases connectivity, the spillover impact of individual actions grows. Many of these spillovers are positive. Evidence includes the close correlation between urbanisation and development. When people come together they can do things that they could never achieve on their own. However as incomes rise, so too do the often unintended negative spillover effects, with examples including obesity, diabetes, climate change, antibiotic resistance and biodiversity loss. Rising inequality and the erosion of social cohesion are also growing risks.

As Sen has explained, a key objective of development is freedom. Freedom to avoid want and starvation, to overcome insecurity and discrimination, and above all to be capable of achieving those things we have reason to value. But with this freedom comes new responsibilities. Our individual contribution to our shared outcomes and as guardians of future generations rises with our own development. If development is to be realised for all people, now and in the future, it is vital that we too develop as individuals. We need to ensure that we are free of the ignorance of how our actions interact with others. Development brings new responsibilities as well as freedoms.

\section{Bibliography}

Acemoglu, D., Johnson, S., \& Robinson, J. (2001). The colonial origins of comparative development: An empirical investigation. Colonialism and development. American Economic Review, 91(5), 1369-1401.

Acemoglu, D., Johnson, S., \& Robinson, J. (2002). Reversal of fortune, geography and institutions in the making of the modern world income distribution. Quarterly Journal of Economics, 117, 1231-1294.

Acemoglu, D., Naidu, S., Restrepo, P., \& Robinson, J. (2014). Democracy does cause growth (NBER working paper 200004). Cambridge, MA: National Bureau of Economic Research.

Adelman, I. (2006). Democracy and development. In D. A. Clark (Ed.), The elgar companion to development studies (pp. 105-111). Cheltenham: Edward Elgar.

Anup, S. (2010). Poverty facts and stats, global issues. Accessed October 10, 2015, from http:// www.globalissues.org/article/26/poverty-facts-and-stats\#src2

Baumol, W. (1986). Productivity growth, convergence and welfare: What the long-run data says. American Economic Review, 76, 1072-1085. 
Bundy, C. (1979). The rise and fall of the South African peasantry. Portsmouth, NH: Heinemann.

Collier, P. (2008). The bottom billion: Why the poorest countries are failing and what can be done about it. Resource endowments and the resource curse. New York: Oxford University Press.

Cruz, M., Foster, J., Quillin, B., \& Schellekens, P. (2015). Ending extreme poverty and sharing prosperity: Progress and policies. No 101740. Policy Research Notes (PRNs), The World Bank, p. 6 and table 1.

Diamond, J. (1997). Guns, germs and steel: A short history of everybody for the last 13,000 years. Geographical explanations of development. London: Vintage.

Easterly, W., \& Levine, R. (2003). Tropics, germs and crops: How endowments influence economic development. Journal of Monetary Economics, 50(1), 3-30.

Frankel, J. (2010). The natural resource curse. Cambridge, MA: National Bureau of Economic Research.

Frankel, J., \& Romer, D. (1999). Does trade cause growth? American Economics Review, 89(3), 379-399.

Goldin, I., \& Reinert, K. (2012). Globalization for development: Meeting new challenges. Globalization and development. New York: Oxford University Press.

Groningen Growth and Development Centre: Statistics on convergent and divergent growth across regions and countries, analysis of long-term growth (1870-2010) utilises available data on GDP per capita in 1990 US\$ from the Madison Project Database, http://www.ggdc.net/maddison/ maddison-project/home.htm (2013 version); the analysis of divergent growth patterns for the period 1960-2014 (including statistics for Ghana, South Korea and China) draws on available data on GDP per capita in 2005 US\$ from the World Bank, World Development Indicators (online). Accessed September 29, 2015, http://data.worldbank.org/

Hirschman, A. (1973). The changing tolerance for income inequality in the course of economic development. Inequality and development. Quarterly Journal of Economics, 87(4), 544-566.

Institute of Development Studies. (2010, September 12). Global poverty and the new bottom billion (Working paper, Sumner, A). Accessed October 10, 2015, from https://www.ids.ac.uk/files/ dmfile/GlobalPovertyDataPaper1.pdf

Kuznets, S. (1955). Economic growth and income inequality. American Economic Review, 45, $1-28$.

Li, H., \& Xu, Z. (2007). Economic convergence in seven Asian economies. Review of Development Economics, 11(3), 531-549.

Page, J. (MIT, 1994). The East Asian miracle: Four lessons for development policy. In S. Fischer \& J. Rotemberg (Eds.), NBER macroeconomics manual 1994 (pp. 219-282). Cambridge, MA. Accessed October 1, 2015, from http://www.nber.org/chapters/c11011.pdf

Parente, S., \& Prescott, E. (1993). Changes in the wealth of nations. Quarterly Review, 17(2), 3-16.

Rodrik, D., Subramanian, A., \& Trebbi, F. (2004). Institutions rule: The primacy of institutions over integration and geography in economic development. Institutions and governance. Journal of Economic Growth, 9(2), 131-165.

Sachs, J. (1989). Developing country debt and the world economy. Chicago: University of Chicago Press.

Sachs, J., \& Warner, A. (1995). Economic convergence and economic policies. Relationship between trade and development. Cambridge, MA: National Bureau of Economic Research.

Sen, A. (1981). Poverty and famines: An essay on entitlement and deprivation. The role of power and other factors. Oxford: Clarendon Press.

Singh, A. (1995, February 8). "Close" vs. "Strategic" integration with the world economy and the "Market Friendly Approach to Development" vs. "An Industrial Policy" (MPRA paper no. 53562). Accessed October 1, 2015, from https://mpra.ub.uni-muenchen.de/53562/1/ MPRA_paper_53562.pdf

Solow, M. R. (1956, February). Uneven development and convergence. A contribution to the theory of economic growth. The Quarterly Journal of Economics, 70(1), 65-94. 
World Bank, Development Research Group. PovcalNet: The online tool for poverty measurement, poverty and inequality. Accessed October 18, 2015, from http://iresearch.worldbank.org/ PovcalNet/index.htm?1

World Health Organization. (2015, September 17). WHO/UNICEF report: Malaria MDG target achieved amid sharp drop in cases and mortality, but 3 billion people remain at risk. Joint WHO/UNICEF News Release. Accessed October 3, 2015, from http://www.who.int/ mediacentre/news/releases/2015/malaria-mdg-target/en/

Open Access This chapter is licensed under the terms of the Creative Commons Attribution 4.0 International License (http://creativecommons.org/licenses/by/4.0/), which permits use, sharing, adaptation, distribution and reproduction in any medium or format, as long as you give appropriate credit to the original author(s) and the source, provide a link to the Creative Commons licence and indicate if changes were made.

The images or other third party material in this chapter are included in the chapter's Creative Commons licence, unless indicated otherwise in a credit line to the material. If material is not included in the chapter's Creative Commons licence and your intended use is not permitted by statutory regulation or exceeds the permitted use, you will need to obtain permission directly from the copyright holder.

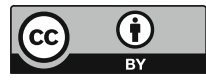




\title{
Measuring the Hard-to-Measure \\ in Development: Dimensions, Measurement Challenges, and Responses
}

\author{
Anne L. Buffardi, Tiina Pasanen, and Simon Hearn
}

\section{Introduction}

As set out in the 2030 Agenda, sustainable development is universal, integrated, and indivisible, and balances economic, social, and environmental dimensions. Initiatives that aim to improve development attempt to address entrenched issues, where previous efforts have been insufficient or adequate responses are not known. They operate under conditions of uncertainty and complexity. Increasingly they involve multi-component or package interventions, delivered by and relating to diverse sets of stakeholders pursuing different, sometimes competing interests, and working in shifting contexts. Each of these factors carry implications for measurement and pose distinct threats to validity and reliability.

In recent years, there has been a greater acknowledgement of these challenges and the need for robust mixed methods and more flexible, adaptive approaches. At the same time, how best to gather, combine, and interpret multiple sources of evidence covering multi-dimensional aspects of economic and social development, and communicate and use this evidence to guide policy and programming remains a formidable challenge. As applied researchers attempting to gather credible evidence on the effects and trajectories of efforts to improve development, we must continually ask not only "Are we measuring it right?", but also, more fundamentally, "Are we measuring the right thing?"

Based on common challenges that arose through development initiatives in a variety of contexts, this contribution explores four hard-to-measure dimensions of development. In particular, we discuss abstract, multi-dimensional concepts, processes, and issues; challenging settings where there are unpredictable, sudden, or frequent shifts in the environment; multiple, uncertain pathways of change; and multi-layer implementing structures such as cross-sector partnerships or regional/

\footnotetext{
A. L. Buffardi $(\bowtie) \cdot$ T. Pasanen $(\bowtie) \cdot$ S. Hearn $(\bowtie)$

Overseas Development Institute (ODI), London, UK

e-mail: a.buffardi@odi.org.uk; t.pasanen@odi.org.uk; s.hearn@odi.org.uk
} 
national/subnational arrangements. These dimensions pose specific difficulties related to what is measured and where, the assessment of how and why changes took place, and who or what is the unit of analysis. In addition to these technical, methodological aspects, relational and political factors also have implications for measurement, even if the issue area, setting, pathway of change, and implementing structure are not inherently difficult.

Distinguishing among these four hard-to-measure dimensions is a fundamental first step in minimising potential threats to validity and reliability. To inform this analysis and discussion, we draw on work from policy evaluation and international development, where debates about measurement have featured prominently in recent years.

Scholarship on evidence-informed decision-making has highlighted the importance of the nature of the evidence - its quality, credibility, and relevance-as well as individual, interpersonal, organisational, inter-organisational, and broader contextual factors that can affect the extent to which evidence is used and how (Jones et al. 2012; Bossuyt et al. 2014; Punton 2016). In this contribution, we focus on measurement challenges that affect the credibility of evidence, the sources of information that can help inform development policy and practice. We acknowledge, however, that just as important is the way a particular piece of evidence is integrated with other sources, and how different stakeholders, including decision-makers, are engaged throughout the process.

\section{Disconnect Between Research and Reality}

There is widespread recognition that development is about multi-dimensional, sustained system-wide changes. The EU, for example, supports programmes on agriculture and rural development, employment and social inclusion, and regional and urban development. The EC Directorate-General for International Cooperation and Development (2017) aims to reduce poverty, ensure sustainable development, and promote democracy, peace, and security. Each of these areas are possible to measure - poverty, inequality, social inclusion, conflict—but represent reversible outcomes that are affected by many factors, which may include but are certainly not limited to a single government ministry or an EU development grant.

The mismatch between expectations and what is plausible to achieve and attribute to a single source can frustrate rather than enhance accountability among those designing, delivering, and intended to benefit from development policies. While these tensions often surface through measurement processes, they reflect more fundamental matters, discussed further in the final section.

The bounded nature of measurement poses additional challenges in trying to assess multi-dimensional, sustained system-wide changes. Like development policies and programmes themselves, measurement is conducted within time and budget constraints. In order to ensure adequate internal validity, account for alternative explanations for change, and strengthen causal claims, research and evaluation must 
focus on a limited set of questions in order to investigate multiple potential explanatory factors in sufficient depth, comparing instances of presence and absence. Measuring development tends to focus on project-specific changes over relatively short time frames, or very broad aggregates that mask differences across subpopulations and regions. Therefore, the broad, interconnected, and long-term nature of social and economic change processes, and the necessarily bounded nature of development initiatives and their measurement, can be difficult to reconcile.

\subsection{Complicated, Complex, and Hard to Measure}

Indeed, these challenges have re-energised the discourse on complexity, which has been prominent in the field of international development and in cross-government initiatives in some EU countries, and is widely relevant across a range of contexts (Eoyang and Berkas 1998; Glouberman and Zimmerman 2002; Kurz and Snowden 2003; Ramalingam et al. 2008; Mowles et al. 2008; Hall and Clark 2010; Rogers 2011; Hummelbrunner and Jones 2013a, b; Mowles 2014; Copestake 2014; Matthews 2016; Root et al. 2015; Buffardi 2016). Scholars have drawn insights from complexity theory, characterising key elements in different ways (Fig. 1). They note the importance of clarifying which aspects of a development initiative have these features, rather than characterising the initiative in its entirety as complex (Rogers 2011; Woolcock 2013; Yin 2013).

As attention to complexity has heightened, there is a risk that the term is misused and overapplied to situations or aspects of a programme that do not fit these characteristics but that may nevertheless be difficult or challenging. As Peersman et al. (2016) note, what is complex is not just very, very complicated; rather, it is characterised by its dynamic and emergent nature, which requires ongoing knowledge generation to gauge what is working given current conditions and what is the best way forward. These questions imply a different focus than with complicated (rather than complex) aspects of interventions, which ask what works more and less well for whom and under what conditions.

In working with development initiatives-most of which have elements that are fairly straightforward, complicated, and uncertain - we have found that measurement challenges are just as often complicated as they are complex; and that these terms are applied inconsistently, sometimes causing confusion for decision-makers and programme staff. Therefore, we use the term "hard-to-measure" to avoid this confusion and focus on the common challenges that emerged in working with large development initiatives. These challenges fall along four dimensions: abstract, multi-dimensional concepts, processes, and issues; challenging settings; multiple, uncertain pathways of change; and multi-layer implementing structures. We explore each in turn in the next section.

For some areas with well-established assessment indicators, measurement can be problematic because of the mismatch between expectations and what is plausible and feasible to observe over what periods of time, rather than because of technical, 
Core features of complex programmes:

1. Distributed capacities, when skills, resources and actions are dispersed across many actors, institutions and geographies, whose joint interaction is required to address a problem

2. Goal divergence, when these actors have different perspectives about the problem and/or how to best address it

3. Uncertainty, incomplete knowledge or understanding about how to achieve desired outcomes in a particular context

Ramalingam et al. 2008, Jones 2011

Causal density, based on:

- Intensity of transactions among individuals

- Level of discretion of implementation staff

- Contentiousness, pressure to do something other than implement a solution

- Existence of known solutions

Woolcock 2013

- Confidence of causality: the extent to which the problem and the effectiveness of the response is understood

- Confidence in context. the extent to which the political and operational contexts are understood and can be influenced

IDS \& USAID 2015, Valters et al. 2016

- Problem-related complexity, one with multiple elements, variability in the environmental and sociodemographic characteristics of the area, spread and scale of the problem, level of unpredictability

- Policy/response related complexity, multiple components, multiple stakeholders, degree of flexibility or tailoring during implementation, spread and scale of the response, competing or interacting policies

- Impact-related complexity, multiple expected outcomes, unexpected impacts, interactions between policy components, difficulty in causal attribution, time scales over which impacts might occur, availability of information relating to impacts

Centre for the Evaluation of Complexity Across the Nexus (Sheate et al. 2016)

Fig. 1 Different characterisations of complexity, as applied to development

methodological challenges themselves. We also acknowledge and briefly discuss these situations in the final section.

\section{Distinguishing the Hard-to-Measure Aspects of Development: Four Dimensions}

Each hard-to-measure dimension corresponds to the what, where, how, why, and who of implementation and measurement. Each dimension faces distinct threats to reliability and internal validity, the foundational elements of any measurement 
exercise: whether repeated investigation would yield the same findings, and the credibility of the results, whether the investigation measures what it intends to measure.

Internal validity can be compromised by a number of factors, including history effects, events that occur in the external environment between measurement time points; maturation, processes within the individual operating as a function of the passage of time, not related to particular events (i.e. ageing); testing, effects of the measurement exercise itself; instrumentation, when measurement tools or processes vary; selection, when individuals choose to take part in an intervention or are identified in non-systematic ways; and attrition, when people leave the programme before it is completed (Campbell and Stanley 1963). More robust study and instrument designs can minimise these threats, and so may be particularly warranted for specific hard-to-measure dimensions.

Table 1 presents each dimension with an example and the primary measurement challenges and risk associated with it. After examining each in turn, we discuss interactions and commonalities among the four dimensions, including additional biases which affect measurement and implications for external validity.

Table 1 Hard-to-measure dimensions

\begin{tabular}{|c|c|c|}
\hline Dimension & Explanation and example & $\begin{array}{l}\text { Measurement challenge and } \\
\text { risk }\end{array}$ \\
\hline $\begin{array}{l}\text { Abstract, multi-dimen- } \\
\text { sional concepts, pro- } \\
\text { cesses, and issues (what) }\end{array}$ & $\begin{array}{l}\text { Intangible, often unobservable } \\
\text { concepts for which proxy indica- } \\
\text { tors must be used: development, } \\
\text { social inclusion, empowerment, } \\
\text { strengthened partnerships, and } \\
\text { institutions }\end{array}$ & $\begin{array}{l}\text { - Construct validity-does the } \\
\text { indicator represent the concept } \\
\text { it's trying to measure? } \\
\text { Risk of measuring the wrong } \\
\text { thing }\end{array}$ \\
\hline $\begin{array}{l}\text { Challenging settings } \\
\text { (where) }\end{array}$ & $\begin{array}{l}\text { Unpredictable, sudden, and/or fre- } \\
\text { quent shifts in the implementing } \\
\text { environment }\end{array}$ & $\begin{array}{l}\text { - Lack of data } \\
\text { - Reliability } \\
\text { - Instrumentation threat to } \\
\text { validity } \\
\text { - Higher attrition, changes in } \\
\text { the profile of participants/ } \\
\text { sample } \\
\text { - Higher likelihood of history } \\
\text { effects } \\
\text { Risk of measuring different } \\
\text { things and/or in different ways }\end{array}$ \\
\hline $\begin{array}{l}\text { Multiple, uncertain } \\
\text { pathways of change } \\
\text { (how and why) }\end{array}$ & $\begin{array}{l}\text { Multiple, interacting, and/or } \\
\text { unforeseen trajectories of change } \\
\text { leading to multiple, unforeseen } \\
\text { outcomes }\end{array}$ & $\begin{array}{l}\text { - Causal attribution, given } \\
\text { equifinality and multifinality } \\
\text { - Omitted variable bias } \\
\text { Risk of misattribution, } \\
\text { neglecting key independent or } \\
\text { dependent variables }\end{array}$ \\
\hline $\begin{array}{l}\text { Multi-layer } \\
\text { implementing structures } \\
\text { (who) }\end{array}$ & $\begin{array}{l}\text { Multi-organisation, multi-site, } \\
\text { multi-layered structures: cross- } \\
\text { sector, cross-department, regional/ } \\
\text { national/subnational initiatives }\end{array}$ & $\begin{array}{l}\text { - Unit of analysis } \\
\text { Risk of over-aggregation, } \\
\text { conflating delivery mechanism } \\
\text { with the intervention }\end{array}$ \\
\hline
\end{tabular}




\subsection{Abstract, Multi-Dimensional Concepts, Processes, and Issues}

The first hard-to-measure dimension relates to abstract, multi-dimensional concepts, processes, and issues-what precisely is being measured. This relates to Jones' complexity feature of goal divergence, when actors have different perceptions of the problem. The very concept of development exemplifies this dimension. What exactly does sustainable development entail? What types of inequality are most problematic? Concepts like social inclusion, empowerment, accountability, and strengthened partnerships or institutions reflect intangible concepts that may be conceived of and interpreted differently. Therefore, unlike a child's weight, household assets, or agricultural yields, they require the use of proxy indicators to assess their presence, absence, or strength. These proxies themselves may be difficult to observe and so may be more heavily reliant on perceptions rather than measured directly.

For example, Sustainable Development Goal 5, which aims to achieve gender equality and empower all women and girls, uses 14 indicators to measure these concepts, including legal frameworks to enforce non-discrimination, prevalence of intimate partner violence, early marriage, female genital mutilation, unpaid domestic and care work, seats held in national and local government, women in managerial positions, access to information about and decisions regarding sexual and reproductive health and rights, agricultural land ownership, mobile phone ownership, and presence of systems to track and make public allocations for gender equality and women's empowerment (UN-DESA n.d.). The OECD operationalises "better life" as housing, income, jobs, community, education, environment, civic engagement, health, life satisfaction, safety, and work-life balance.

Development programmes often aim to improve a mix of issues that are straightforward and more difficult to measure: increased household income and forest coverage as well as more participatory and inclusive decision-making in natural resource management committees and stronger cross-sector partnerships. The key measurement challenge with abstract, multi-dimensional concepts and issues is construct validity: to what extent does the indicator(s) accurately reflect the underlying theoretical construct or concept? Simply stated, poor construct validity risks measuring the wrong thing.

This measurement challenge can be mitigated by providing clear operational definitions; for example, explicitly stating "by gender equality, this programme is referring to changes in the proportion of women elected to and serving on district councils". For programmes involving many stakeholders, it may require bringing these groups together (i.e. researchers across disciplines, local government officials, programme staff, community members) to discuss their interpretation of the concept. As illustrated above, multi-dimensional concepts are also addressed by using multiple indicators or composite indices to capture different elements of a broader concept. The use of multiple indicators tailored to a particular context may increase construct validity in that study. At the same time, the use of different indicators 
across programmes or locations limits comparisons and precludes quantitative aggregation like meta-analyses so the broader field may have a less-consolidated evidence base.

\subsection{Challenging Settings}

The second dimension refers to where development policies, programmes, and their measurement are taking place. The economic, political, and/or physical environment may be unpredictable and highly unstable. In some settings, instability may be more predictable in the sense that these shocks may be anticipated but they are frequent and interrupt both programming and measurement. Or, destabilising events may be infrequent and predicted but with rapid onset, such as natural disasters, which leave little time to change activities if contingency plans have not already been established. These settings reflect volatility, the likelihood that important contextual or causal conditions may change quickly (Booth et al. 2016) and are one example of context complexity. This may include shocks as a result of an economic crisis, the intensity and manifestation of which may vary by sector and locale. It could be geographical pockets where migration flows significantly affect the local context, or agricultural areas that are more prone to natural disasters.

Unpredictable, frequent, and/or rapid shifts in the environment affect measurement reliability, whether repeated assessment would find the same results. Rather than measuring the wrong thing, as is the risk with multi-dimensional concepts, challenging settings risk measuring different things and/or in different ways.

If environmental or security concerns prevent access to certain areas or groups, the timing of data collection may be delayed. In some cases, it may not be possible to take multiple measures over time. If these shocks prompt population movement, attrition may be higher than average. The profile of participants or the population sample from which the measures are taken may differ over time. The use of alternative approaches, like remote monitoring techniques, may increase threats to internal validity as a result of instrumentation; that is, observed changes may be a result of the different way data was gathered at different points in time: direct measurement and then remote monitoring. Attempts to minimise these measurement challenges may involve taking more frequent measurements, increasing initial sample sizes, investing more in the follow-up to find displaced participants, and using multiple instruments or assessment measures; for example, using both remote and direct monitoring when access is not limited in the event that it is later restricted.

Measurement within shifting contexts is more likely to suffer from history effects, changes over time in the external context that contribute to or explain the observed outcomes rather than the intervention itself. And, the unique nature of the context may make it difficult to identify suitable comparison groups, which could help to account for history effects.

Other challenges may not be able to be addressed and therefore must be taken into account in the analysis and interpretation. Information may have been destroyed, or 
access to documents and/or people may be tightly controlled. Even if it is possible to access specific population groups, refugees, for example, they may be reluctant to disclose information (Jones and Pellini 2009; Cramer and Goodhand 2011).

There have been extensive discussions of some of these challenges in the humanitarian sector, which offer important lessons for other contexts facing environmental, political, or economic instability (Waldman 2014; Bush and Duggan 2015; ALNAP 2016).

\subsection{Multiple Uncertain Pathways of Change}

How and why changes take place-particularly when multiple, interacting, and/or unknown trajectories of change may lead to multiple and unforeseen outcomes-is the dimension discussed most frequently in the literature. Many of the categorisations of complexity relate to this dimension: Woolcock's four aspects of causal density, IDS and USAID causal complexity, and two of Jones' three features of complex programmes: uncertainty about how to achieve desired outcomes and goal divergence regarding how best to address them.

Where a variable is situated along the pathway of change may be uncertain or contested. For example, strengthened partnerships across actors in different sectors may be an intended outcome of a programme and/or it may be seen instrumentally as a way to enable economic and social outcomes for rural farmers.

The key measurement challenge here is causal attribution, given equifinality (multiple pathways) and multifinality (multiple outcomes). With a large number of potential variables and configurations, omitted variable bias may be a concern-the possibility that changes are influenced by factors that are not being measured. Thus, misattribution and oversight of key independent and/or dependent variables are the primary risks.

Different methods attempt to account for multiple independent variables and the interactions between them and improve causal inference. Multivariate regression can include interaction effects. Process tracing systematically investigates alternative explanations for change (Collier 2011). Qualitative comparative analysis tries to identify necessary and sufficient conditions associated with a particular outcome (Befani 2016). Realist evaluation examines context-mechanism-outcome configurations (Westhorp 2014). The relative merits of different methods have been discussed extensively elsewhere (Stern et al. 2012; Stame 2010; White 2010; Chambers et al. 2009); however, there are still relatively few examples of these latter approaches being applied in development.

\subsection{Multi-Layer Implementing Structures}

The final hard-to-measure dimension is more complicated than complex: multiorganisational, multi-site, multi-layer, often multi-sector implementing structures. 
It refers to who or what unit(s) are being measured. ${ }^{1}$ In this case, it reflects who is delivering the policy or programme and, correspondingly, the unit(s) of data collection, analysis, and reporting. Multi-layer implementing structures reflect Jones' category of distributed capacities, when skills, resources, and actions are dispersed across many actors, institutions, and geographies, whose combined efforts are (thought to be) required to address a problem.

Multi-unit implementing structures appear to be becoming more common. These include cross-sector initiatives and those operating at regional, national, and subnational levels. They could include public-private partnerships or consortium arrangements where multiple organisations work together to deliver a joint EU-funded development project, and multi-project programmes where multiple consortia or projects are grouped together under a wider programme umbrella around a common theme and funding source (Buffardi and Hearn 2016). Numerous programmes may then be nested within broader ministry portfolios or workplans. Other more complicated implementing structures, relative to a single organization or department delivering a single site project, also include networks and coalitions (Hearn and Mendizabal 2011) and regional NGO associations (Davies 2016).

In these types of initiatives, the measurement challenge relates directly to the structure: determining the appropriate unit of collection and analysis. The risk with multi-layer initiatives is over-aggregation, conflating dissimilar units and presenting findings together rather than according to more cohesive and logically or operationally bounded subgroups (Bowman et al. 2013). A large diverse agriculture portfolio with scores or sometimes even hundreds of projects can look broadly at spend rates, the reach and profile of individuals with whom the projects have interacted, and identify particular cases to illustrate different elements of the portfolio and the extent to which those projects contribute to specific outcomes. However, assessing the entire portfolio or a large multi-project programme in aggregate may not be appropriate.

The risk of over-aggregation can be addressed by gathering, analysing, and presenting data according to its multiple nested layers. Clarifying common elements or the purpose of more aggregate structures can help determine the extent to which it is appropriate to use standardised approaches and combine data. Although there has been increasing recognition of the importance of disaggregating data, relative to the other three dimensions, the implications of multi-layer implementing structures are discussed much less often in the development and evaluation literatures.

In our recent experience, challenges related to this dimension have been more prominent than the other three in practice, in part perhaps because measurement challenges are confronted at the outset of implementation when programmes attempt to design a common measurement framework rather than at later phases of the programme when causal pathways are being tested. When development policies and programmes are led by a single government ministry, this dimension is less of an

\footnotetext{
${ }^{1}$ It is also fundamental for accurate measurement to determine the correct unit of analysis at a project level—whether to gather data on individuals or households, for example.
} 
issue. However, it becomes more salient as more stakeholder groups become involved: multiple departments and agencies at regional, national, and subnational levels, private sector, nongovernmental organisations, farmer associations, and community groups.

\subsection{Commonalities and Intersections Among Hard-to-Measure Dimensions}

The particular threats to internal validity and reliability highlighted above represent those that are most problematic for each dimension. Measurement efforts associated with all four dimensions may also be affected by other factors, including recall, interviewer, testing, social desirability, and confirmation biases. Incomplete and inconsistent data collection, which is not uncommon with routine monitoring data from development programmes, may produce biased, non-representative findings.

In addition to the threats to internal validity, these four dimensions all have implications for external validity, limiting the extent to which findings can be generalised to other populations and settings. For instance, how abstract, multidimensional concepts are interpreted is likely to vary across districts, countries, and population groups. Challenging settings are more likely to affect the delivery of development programmes and directly influence outcomes so findings may be generally relevant to settings that share similar characteristics (i.e. frequent flooding, a weak decentralised government) but it is unlikely that they will be directly applicable. Similarly, the interactions of specific actors and configurations of them may influence delivery and outcomes so findings may differ when programmes are led by a single department or organisation or by different implementing structures and different sets of actors within them. When multiple interacting pathways of change and many outcomes are possible, some pathways and outcomes may be particularly relevant for certain populations and contexts more than others. By their very nature, elements of development programmes that are truly complex (rather than very complicated) are unknowable (Peersman et al. 2016) so specific findings cannot be directly transferred to other situations. However, there may be lessons about processes and adaptation that are more broadly relevant.

Across the four dimensions there may also be areas of overlap and interdependency. Uncertain pathways of change, in particular, may be affected by the other three hard-to-measure areas. Concepts and issues that are less well defined may have more potential trajectories of change, which may also be poorly specified. The roles of individuals, subgroups, and larger umbrella group structures may complicate causal attribution. In addition, history effects that are more likely in challenging settings raise alternative explanations for change that must be taken into account when attempting to assess causality. 


\section{Discussion and Conclusions}

In the last two decades, attention to the measurement and results of government programmes and development initiatives has heightened significantly. There have been lively debates in the field about the relative merits of different methodological approaches and extensive discussions about complexity. At the beginning of the Sustainable Development Goal (SDG) era, we know considerably more about development than we did when the first UN Human Development Report was launched in 1990.

At the same time, formidable challenges remain-both in terms of measurement and, more fundamentally, how to advance the multi-dimensional, sustainable, system-wide changes that development aims to achieve. Identifying what is hard to measure can help specify threats to internal and external validity and reliability so they can be minimised and accounted for in study design, analysis, and interpretation. There is cause for both optimism and vigilance-measurement can be improved to enhance understanding of hard-to-measure areas but researchers must continually question and advance their approaches in order to keep pace with the world we are investigating.

\subsection{The Feasibility of More?}

We acknowledge that attempts to address the measurement challenges in each hardto-measure dimension all involve doing more of something: using multiple measures to capture a broad concept, gathering data more frequently, with multiple instruments and on larger samples to anticipate shifts in the context, restricted access and higher attrition, gathering and analysing information at each of the multiple layers of complicated implementing structures, and testing many potential pathways of change. The extent to which more monitoring and more comprehensive evaluation is feasible in government and development programmes whose primary aim is implementation may limit the degree to which these challenges can be addressed. For selected conceptual areas, settings, pathways of change, and implementing structures, approaching these challenges through more in-depth substantive research may be more viable than through a relatively small monitoring and evaluation component of a large development initiative.

\subsection{Relational and Political Factors Affecting Measurement}

Furthermore, although this chapter has focused on measurement challenges, it is just as important to recognise relational and political factors that influence the design, implementation, and evaluation of development programmes. As noted in the 
introductory chapter, development is far from being solely a "technical" problem. One drawback of the heightened attention to measurement issues has been an overemphasis on technical elements and relative lack of attention to these relational factors. These difficulties often arise as a result of a mismatch between expectations and what is plausible and feasible to observe in a particular time frame-essentially, trying to measure and attribute too much too soon. Pressures to demonstrate "success" and value for money can exacerbate these unrealistic expectations.

Some pathways and outcomes may not necessarily be complicated or complex but may take time before they can be observed. Assessing sustainability, for example, asks to what extent programmes and benefits continued after the programme ended. This question is not inherently difficult but by definition it cannot be assessed until after the programme period.

In addition to pressures to measure sustainability or impacts before they can be observed are situations where programmes attempt to measure too much. Laundry lists of questions and indicators often reflect efforts to be inclusive and covering multiple perspectives and dimensions. However, attempts to answer too many questions result in none being measured in a credible, robust way. Issues of attribution present another challenge - claiming rather than attempting to measure too much. It is rare that a single programme or actor is the only one trying to address a particular issue or working with a group of people.

Relational and political factors are present even in small, relatively straightforward projects but may be intensified in programmes with hard-to-measure elements and manifested in different ways across the four dimensions. By definition, multilayer implementing structures involve many diverse actors, with different levels of authority and power, who may have different priorities. They may see one another as competitors rather than collaborators and so may be reluctant to share information. Prioritising some questions over others, or using one operational definition of an abstract, multi-dimensional concept rather than another, is an inherently political process. In effect, it validates or elevates certain conceptions and minimises or ignores alternative interpretations. Resolving contested understandings of women's empowerment requires transparent processes of deliberation, not necessarily more or a different type of information.

Similarly, choosing which indicators are included and which are excluded in a national development index involves trade-offs. This is also the case for multiple, uncertain pathways when a long list of potential mediating and outcome variables will need to be bounded. The need to make quick decisions in response to a rapidly shifting environment precludes extensive, inclusive, deliberative processes.

Guidance and evaluation tools exist to help structure processes of stakeholder discussion and prioritisation processes (Peersman et al. 2015; Hearn and Buffardi 2016). However, deciding how development programmes should be judged and resources allocated are potentially contentious processes and there is not a technical fix that can be applied. At the heart of measuring and claiming too much too soon are questions about accountability. Who is responsible to whom, for what and when?

Distinguishing relational political challenges from technical methodological ones and clarifying among specific hard-to-measure dimensions are important because 
they require different responses to address the underlying problem. They pose distinct threats to measurement validity, reliability, feasibility, and use of evidence that need to be accounted for and minimised to the extent possible. Credible evidence is a foundational component of understanding and improving development-and is indeed a necessary but insufficient condition for evidence-informed decision-making.

\section{References}

ALNAP. (2016). Evaluation of humanitarian action guide: Active Learning Network for Accountability and Performance (ALNAP) in humanitarian action. London: ALNAP/ODI.

Befani, B. (2016). Pathways to change: Evaluating development interventions with Qualitative Comparative Analysis (QCA). Stockholm: EBA.

Booth, D., Harris, D., \& Wild, L. (2016). From political economy analysis to doing development differently: A learning experience. London: ODI.

Bossuyt, J., Shaxson, L., \& Datta, A. (2014). Assessing the uptake of strategic evaluations in EU development cooperation. http://ec.europa.eu/europeaid/how/evaluation/evaluation_reports/doc uments/2014/1331_uptake_strategic_evaluation_annexes_en.pdf

Bowman, K., Buffardi, A. L., \& Freeman, S. (2013). Who interacts with whom, about what and when? Evaluation and learning in multi-issue global networks. Paper presented at the American Evaluation Association, Washington, DC.

Buffardi, A. L. (2016). When theory meets reality: Assumptions, feasibility and implications of a complexity-informed approach (A Methods Lab publication). London: Overseas Development Institute.

Buffardi, A. L., \& Hearn, S. (2016). Multi-project programmes: Functions, forms and implications for evaluation and learning. A Methods Lab publication. London: ODI.

Bush, K., \& Duggan, C. (2015). Evaluation in the extreme: Research, impact and politics in violently divided societies. New Delhi: SAGE.

Campbell, D. T., \& Stanley, J. C. (1963). Experimental and quasi-experimental designs for research. Chicago: Rand McNally.

Chambers, R., Karlan, D., Ravallion, M., \& Rogers, P. (2009). Designing impact evaluations: Different perspectives. International Initiative for Impact Evaluation Working Paper 4. New Delhi: 3ie.

Collier, P. (2011). Understanding process tracing. Political Sciences and Politics, 44(4), 823-830.

Copestake, J. (2014). Credible impact evaluation in complex contexts: Confirmatory and exploratory approaches. Evaluation, 20(4), 412-427.

Cramer, C., \& Goodhand, J. (2011). Hard science or waffly crap? Evidence-based policy versus policy-based evidence in the field of violent conflict. In K. Bayliss, B. Fine, \& E. Van Waeyenberge (Eds.), The political economy of development: The World Bank, neoliberalism and development research. London: Pluto Press.

Davies, R. (2016). Evaluating the impact of flexible development interventions using a "loose" theory of change. A Methods Lab publication. London: ODI.

Eoyang, G. H., \& Berkas, T. (1998). Evaluation in a complex adaptive system: Managing complexity in organizations. Westport, CT: Quorum Books.

European Commission Directorate-General for International Cooperation and Development (DG DEVCO). (2017). Mission statement. Retrieved September 4, 2017, from https://ec. europa.eu/europeaid/mission-statement_en 
Glouberman, S., \& Zimmerman, B. (2002). Complicated and complex systems: What would successful reform of Medicare look like? Toronto: Commission on the Future of Health Care in Canada.

Hall, A., \& Clark, N. (2010). What do complex adaptive systems look like and what are the implications for innovation policy? Journal of International Development, 22(3), 308-324.

Hearn, S., \& Buffardi, A. L. (2016). What is impact? A Methods Lab publication. London: ODI.

Hearn, S., \& Mendizabal, E. (2011). Not everything that connects is a network. London: ODI.

Hummelbrunner, R., \& Jones, H. (2013a). A guide for planning and strategy development in the face of complexity. ODI Background Note. London: ODI.

Hummelbrunner, R., \& Jones, H. (2013b). A guide to managing in the face of complexity. ODI Working Paper. London: ODI.

Institute of Development Studies (IDS) and USAID Learning Lab. (2015). Learning to adapt: Exploring knowledge, information and data for adaptive programmes and policies. Workshop Report. Brighton: IDS.

Jones, H. (2011). Taking responsibility for complexity. London: ODI.

Jones, N., \& Pellini, A. (2009). Evidence-informed policy in post-conflict contexts: Nepal, Peru and Serbia. London: ODI.

Jones, H., Jones, N. A., Shaxson, L., \& Walker, D. (2012). Knowledge, policy and power in international development: A practical guide. Bristol: Policy Press.

Kurz, C., \& Snowden, D. (2003). The new dynamics of strategy: Sensemaking in a complex world. IBM Systems Journal, 42(3), 462-483.

Matthews, M. (2016). How better methods for coping with uncertainty and ambiguity can strengthen government - Civil society collaboration. In G. Carey, K. Landvogt, \& J. Barraket (Eds.), Designing and implementing public policy: Cross-sectoral debates. London: Routledge.

Mowles, C. (2014). Complex, but not quite complex enough: The turn to the complexity sciences in evaluation scholarship. Evaluation, 20(2), 160-175.

Mowles, C., Stacey, R., \& Griffin, D. (2008). What contribution can insights from the complexity sciences make to the thinking and practice of development management? Journal of International Development, 20(6), 804-820.

Peersman, G., Guijt, I., \& Pasanen, T. (2015). Evaluability assessment for impact evaluation: Guidance, checklists and decision support. A Methods Lab publication. London: ODI.

Peersman, G., Rogers, P., Guijt, I., Hearn, S., Pasanen, T., \& Buffardi, A. L. (2016). When and how to develop an impact-oriented monitoring and evaluation system. A Methods Lab publication. London: ODI.

Punton, M. (2016). Building Capacity for the Uptake of Research Evidence (BCURE) literature review: How can capacity development promote evidence-informed policymaking? Brighton: ITAD.

Ramalingam, B., Jones, H., Reba, T., \& Young, J. (2008). Exploring the science of complexity: Ideas and implications for development and humanitarian efforts. ODI Working Paper 285. London: ODI.

Rogers, P. J. (2011). Implications of complicated and complex characteristics for key tasks in evaluation. In K. Forss, M. Marra, \& R. Schwartz (Eds.), Evaluating the complex: Attribution, contribution, and beyond (Comparative Policy Evaluation series) (Vol. 18, pp. 33-52). New Brunswick, NJ: Transaction.

Root, H., Jones, H., \& Wild, L. (2015). Managing complexity and uncertainty in development policy and practice. London: ODI.

Sheate, W.R., Twigger-Ross, C., Papadopoulou, L., Sadauskis, R., White, O., Orr, P., Phillips, P., \& Eales, R. (2016) Learning lessons for evaluating complexity at the nexus: A meta-evaluation of CEP projects. Final Report to CECAN. https://doi.org/10.13140/RG.2.2.21468.18565.

Stame, N. (2010). What doesn't work? Three failures, many answers. Evaluation, 16(4), 371-387.

Stern, E., Stame, N., Mayne, J., Forss, K., Davies, R., \& Befani, B. (2012). Broadening the range of designs and methods for impact evaluations. Report of a study commissioned by the Department for International Development. DFID Working Paper 38. (Vol. DFID), London. 
UN-DESA and Sustainable Development Goal 5. Retrieved from http://www.un.org/ sustainabledevelopment/gender-equality/

Valters, C., Cummings, C., \& Nixon, H. (2016). Putting learning at the centre: Adaptive development programming in practice. London: ODI.

Waldman, T. (2014). The use of statebuilding research in fragile contexts: Evidence from British policymaking in Afghanistan, Nepal and Sierra Leone. Journal of Intervention and Statebuilding, 8, 149-172.

Westhorp, G. (2014). Realist impact evaluation: An introduction. A Methods Lab publication. London: ODI.

White, H. (2010). A contribution to current debates in impact evaluation. Evaluation, 16(2), 153-164.

Woolcock, M. (2013). Using case studies to explore the external validity of "complex" development interventions. Evaluation, 19(3), 229-248.

Yin, R. K. (2013). Validity and generalization in future case study evaluations. Evaluation, 19(3), 321-332.

Open Access This chapter is licensed under the terms of the Creative Commons Attribution 4.0 International License (http://creativecommons.org/licenses/by/4.0/), which permits use, sharing, adaptation, distribution and reproduction in any medium or format, as long as you give appropriate credit to the original author(s) and the source, provide a link to the Creative Commons licence and indicate if changes were made.

The images or other third party material in this chapter are included in the chapter's Creative Commons licence, unless indicated otherwise in a credit line to the material. If material is not included in the chapter's Creative Commons licence and your intended use is not permitted by statutory regulation or exceeds the permitted use, you will need to obtain permission directly from the copyright holder. 


\title{
Get It Right This Time? Leaving the Periphery of the European Economic Development
}

\author{
Cristian Păun and Florina Pînzaru
}

\section{Introduction}

Since 1990, Central and Eastern Europe countries have undergone a complex process of transition from planned to market economy. Such a process had never taken place before and it brought about a series of challenges and incertitude. There was no precedent, there was no optimum solution for the transition, and the expertise required for such an ample process was non-existent. Each country in the region approached transition in its own way, considering both its specificity and its available resources. Almost three decades later, the Central and East European countries display a different picture of their economic and social achievements.

Looking at the GDP in 1990, the states referred to were very close: at that time, Romania's GDP was 59.1\% of Poland's, about double Bulgaria's and like that of the Czech Republic. Poland's GDP represented $49 \%$ of the aggregate GDPs of Hungary, Romania, the Czech Republic, and Bulgaria. A quarter of a century later, in 2015, all the above-mentioned countries could boast upward-evolving GDPs. For instance, during 1990-2015, Romania's GDP grew 4.56 times, and Poland's 7.23 times. In 2015 Poland was in pole position, at an over 7-time increase. Poland had become, in 2015, the absolute champion of the area, irrefutably leaving the platoon behind:

This chapter has been prepared with financial support granted in the project "State of the Nation. Designing an innovative instrument for evidence-based policy-making" (SIPOCA 11, MySMIS 118305), which is co-financed by the European Social Fund through the Operational Programme Administrative Capacity 2014-2020.

\section{Păun $(\bowtie)$}

Bucharest University of Economic Studies, Bucharest, Romania

e-mail: cristian.paun@rei.ase.ro

F. Pînzaru $(\bowtie)$

National University of Political Studies and Public Administration, Bucharest, Romania e-mail: florina.pinzaru@facultateademanagement.ro 
in 2015, Poland's GDP represented $89 \%$ of the cumulated GDPs of the Czech Republic, Hungary, Romania, and Bulgaria for the same year, compared to the $49 \%$ in 1990. In other words, Poland had become the driving engine of the area (World Bank Database 2017).

In its evolution, Romania's GDP experienced three major crises: the crisis that followed the change of the economic system (1990-1992), the liquidity crisis in 1998-1999 when Romania's peak reimbursement of the foreign debt to Japan overlapped with a regional crisis (Russia in 1998) and a global one (South America in 1999), and, finally, the global crisis of 2008-2009, subsequently extended into the sovereign debt crisis at the level of the European Union, which made it more difficult for all the countries in the Economic Community to recover. The impact of economic collapse caused by the change of the economic system was $35 \%$, the recession generated by the liquidity crisis $14 \%$, and that caused by the global crisis $19 \%$ (World Bank Database 2017).

Romania's economic growth was only sustained after 2000. This could be explained by Romania's acceptance as a candidate to join the EU, which opened a series of opportunities, and the sustained program of market liberalization and privatization. Unfortunately, the European integration brought about growth of the GDP that was more supported before rather than after the effective joining, which caused increasing contagion risks, also noticeable in the way the GDP evolved after 2007 (highly frequent growths followed by abrupt falls). Claims that the economic growth has not turned into development are increasing; one could rather talk about stagnation and of placing Romania, in many respects, at the periphery of the Central and Eastern Europe member states. In what follows, we shall look at why this is happening and how such a situation can be changed.

\section{At the Periphery of the European Development: Romania's Economic Growth, With the Parking Brake Pulled Up}

The lack of vision and the stereotypical approach of the various economic ideas led to a situation where, almost three decades after the fall of communism, in 2017, Romania is the "tiger of Europe" in economic growth, scoring a 5.7\% GDP raise, compared to the $2.3 \%$ EU average (European Commission 2017), without this explicitly reflecting in welfare. In 2017 Romania ranks among the last in the European Union in GDP per capita (8607 euro/capita, followed only by Bulgaria at 6752 euro/capita (Eurostat 2017). Moreover, Romania has issues of high inequality: in 2015, the richest $20 \%$ of the population had incomes eight times higher than the poorest $20 \%$ - a significantly larger ratio than the $4.9 \%$ scored by Poland or the $4.3 \%$ by Hungary (Eurostat 2017).

Romania's economic evolution is meandrous and attributed to the lack of structural reforms, displaying, at times, an erroneous understanding of the ideas of economic development. For instance, when consumption underlies economic growth, such 
growth does not necessarily lead to subsequent development if the respective consumption feeds import instead production (Anghel et al. 2014a, b). Between 1990-2000, when direct foreign investments in Romania were very low, modern technology production overcapacities, conceived to cope with extended economic boom periods, were created by the investments made by foreign companies in the countries around, and they are producing there, not in Romania. Today, the main objective of these investments is to find outlet and not production locations (Anghel et al. 2014a, b). With better know-how than Romanian entrepreneurs and managers, the foreign companies have managed to conquer important market shares in Romania - a country ranking second in the region after Poland in size and inhabitants, hence an ideal market for the sale of products manufactured in Central and Eastern Europe countries. According to Eurostat, GDP dependence on consumption in Romania has not changed significantly during the past two decades: final consumption expenses were $79.2 \%$ in 1990 only to drop to $77.6 \%$ in 2013 . The governments in the last decades associated, to a notable extent, economic growth to stimulating consumption. Still, local production could not keep the pace with this consumption increase. Economic growth in Romania has been continually accompanied by an ever bigger external trade deficit (i.e. imports have always increased faster than exports) during these years of transition. Which means that almost always, sooner or later, economic growth in Romania filled the pockets of the inhabitants of the countries in the region that managed to deal with domestic consumption better than the Romanian producers. Maybe this explains why the 2008-2009 crisis affected the Romanian market the most among the countries in the area (in the same period, Poland, for example, had no economic crash).

The positive element that has allowed Romanian business to evolve for the past two decades, is, in fact, the joining of the European Union, although the lag behind the EU average has not considerably diminished; we may even say that it has slightly increased. The absence of a clear vision on development and of a list of priorities of where to constantly allocate resources explains this status quo. Romania failed to maintain its position in the region during 1990-2000, but joining the European Union gave it the opportunity to become a gear in the European production mechanism as a producer of sub-assemblies and components or as a collateral service outsourcing target (Anghel et al. 2014a, b). Nevertheless, this course of market evolvement has inherent limitations in the constraints the outsourcing suppliers in a global context are facing: lower added value, high dependence on the external factors, volatility generated by very high competition. About two-thirds of the Romanian exports are generated by companies active in Romania that have benefited from direct foreign investments (idem), i.e. companies with international level know-how that have chosen to invest in Romania to benefit from the cheaper labor and the currency stability through controlled flotation by the national bank.

Starting in 2007, when it joined the European Union, Romania has followed, to an ever-greater extent, the European model of public spending allocation. It has shrunk allocations for defense and economic activities in favour of those for social security, environment and the public health care system. However, despite the higher budget allocations towards the latter sectors, Romania has not caught up either with 
the EU average or with the other Central and Eastern European countries. Thus, Romanian hospital endowments, although on the rise, remain lacking, e.g. one CAT scanner per 100,000 inhabitants compared to three in Bulgaria (Eurostat 2017). About innovation, Romania ranks 42nd at the global level, behind many East European states-like Slovenia in 32nd place, Latvia in 33rd place and Bulgaria in 36th place (Global Innovation Index 2017). Romania has the lowest share allocated for education in the EU, almost two times lower than the European average, at $2.75 \%$ of the GDP in 2014, compared to Bulgaria's $4.22 \%$ and Poland's $4.91 \%$ (Eurostat 2017).

What exactly has driven Romania to the periphery of economic development such as it is experiencing now, never managing to overtake the last or last-but-one place in the countries of the region platoon? There are three explanations that can lead to possible solutions: (1) for various reasons (a more uncertain political environment, lack of important investments in infrastructure, especially in transport, deindustrialization, etc.), Romania did not benefit as much as the surrounding countries from the wave of investments that followed the fall of communism; (2) it favoured the services, especially trade, which feeds not only domestic economic growth but also that of the other countries in the region that have important production capacities; (3) there was a shortage of domestic capital and limited foreign investments to support development, while, at the same time, funding of short-term profit-generating activities, at the expense of high -added value and knock-on-effect activities, was favoured.

\section{In Search of the Appropriate Strategy of Economic Development}

Romania's economic growth suffers from inconsistency in time, as the economic growth periods have been constantly succeeded by serious crises that have significantly adjusted the GDP downwards, and wherefrom recovery has been difficult. After the fall of communism, Romania took 8 years to reach the 1990 level of the GDP in real terms. Except for the liquidity crisis in 1998-1999, Romania grew continually until 2007 (the year of joining the EU). This period also witnessed deep structural changes, like lowering the agriculture share in the GDP make-up, deindustrialization and the steady growth of services and trade. After joining, while the economic crisis of 2008-2009 was happening, the Romanian economy meandered, experiencing multiple highs and lows in a short lapse of time. Such a volatility indicates an increasing vulnerability in development and explains, to a certain extent, the slow pace of economic growth felt at the level of the individual, and the lag in catching up with the average of the EU countries with more sustainable growth. This volatility points to a lack of strategic vision and a high vulnerability.

Some of the causes that led to this meandrous evolution lie in the modified Romanian economy branch structure: In 2015 the industry share in the GDP had dropped from $49.9 \%$ in 1980 to just $23.3 \%$ while the share of agriculture decreased 
from $12.6 \%$ to just $4.3 \%$ (Eurostat 2017). The civil engineering sector remained relatively steady throughout this long period of time while trade (services in general) was the only sector showing an upwards trend. The engines of development continually decreased their speed.

The process of deindustrialization was very visible right after the fall of communism and it continued after Romania joined the European Union. At the same time, this process was accompanied by a long-term trend of a steady drop in added value in the Romanian industry (with slight recovery spurts after the economic boom periods). Yet, even if not spectacular, the trend is to rise for most of the countries in the region, which means that Romania continues to use many resources with rather modest results, justifiable by the low level of research-innovation and the industry targeting the production of sub-assemblies and parts. Specifically, "out of a 30,000-euro BMW car, just 1000-euro worth is made in Romania: the steering wheel, the belt drives, the mirrors, etc." (Hostiuc 2017).

With 1.39 million employees (INS-National Institute of Statistics 2017), industry is the largest employment sector in the Romanian economy, i.e. approximately one in three employed persons in Romania works in industry (a close level to that is only to be found in the service sector, with 1.33 million employees in 2016). Although industry has the highest added value in the Romanian economy, even with the above-mentioned limitations, its gross productivity per employee stands below that recorded for services and trade (INS 2017). Still, industry or infrastructure investments (in 2017 Romania is the country with the lowest number of kilometres in the European Union and it has no high-speed railway whatsoever) can provide a knock-on effect for the development of other economic sectors and hence the premises for long-term development, beyond short-term profitability. In other words, Romania desperately needs infrastructure and complex industry to overcome the vulnerability generated by its position either at the end of the production chain, as an assembler, or, in the case of agriculture, as a provider of raw materials that are processed abroad and imported as end-products, or somewhere in an intermediate position in the production chain, as a sub-assembly producer that only gets a small part of the added value and is much more vulnerable as it is foreign-dependent. Yet such desideratum cannot be reached unless two fundamental problems, funding and research-innovation, are overcome.

Having opted for encouraging sectors of modest added value will have consequences for a long time. Romania faces a dire future to a large extent because of the ease with which it has given up its advanced expertise in many domains, only to set to roughly processing raw materials or assembling industrial components using cheap local labour. Unfortunately, Romania preferred a peripheral position in this division of work, convenient and of low risk, where everything came from abroad on a plate: raw materials, technology, know-how. Such a mentality, still perpetuated also in the IT and the automotive industries, is very hard to overcome.

Any complex production process involves several distinct stages: one stage where the production process is organized as capital investments in equipment, production and auxiliary facilities, infrastructure, etc.; another stage where such production means are effectively put to work in the various operations intended to 
produce goods and services meant for the market; and, finally, a third stage where the manufactured goods are sold to the final consumers (or intermediate, as the case may be). This process is enabled by specific mechanisms (the market, the price system, etc.). Every stage of the process has a well-defined role. Production cannot be achieved without the initial investment, which involves capital existence. Still, most often equity is not enough to support production processes, which are complex, very innovative and of high added value. In its turn, the added value in the production process depends on the production stages that the entrepreneurs can afford. The more entrepreneurs understand and embrace innovation and the better the available capital is targeted towards investments in production processes of high added value, the more sustainable the economic activity is. Sadly, Romanian industry capitalization stands, at present, below that of the civil engineering sector. The Romanian capital targets civil engineering rather than industry or agriculture, which affects the economic development.

Development funding can be achieved from public or private sources. If public funding belongs rather to the Keynesian economic thinking, with its inherent limitations, private funding is generally specific to entrepreneurship and can be covered from sources such as equity, borrowings or direct foreign investments. At present, the investment project complexity is such that it makes it almost impossible to develop a business only with internal resources, consisting only of reinvested profit or equity owned by the project initiators. To cope with competition in a globalized world, entrepreneurs must cooperate with the other capital holders and be intensely connected to the global financial system. Yet, capital imports, vital for emerging economies where domestic capital shortage is noticeable, involves losing economic independence to some extent, putting additional pressure on the current account deficit and increasing vulnerability to greater contagion from crises and external factors.

The added value in an economy involves developing complex production processes that include as many production stages as possible. Along the manufacturing stages, the need for capital increases as the advanced stages become capital-goods (equipment, technology, etc.) intensive. In other words, a nation's capacity to add economic value strongly depends on the volume of capital. At the same time, we cannot fail to notice that capital inflow is correlated to a specific personal behaviour: saving. Any blip in the relationship added value — capital—saving clearly disrupts development. Nations save in different ways, they allocate capital in different ways, make their own mistakes, and finally get to having different development levels, even if, apparently, their initial resources were similar.

The rate of saving in Romania increased steadily, especially before its joining the European Union and before the 2008-2009 economic crisis (after a significant drop that lasted until 2004-2005). Still, Romania falls short of the region average, displaying insufficient advances compared to countries like Hungary, Slovenia, Slovakia, and the Czech Republic, all with smaller populations. This raises the need to find other funding sources. They can be either efficient public investments, especially from European funds, or sustainable foreign investments that are not speculative.

A funding alternative to saving is represented by the European funds, all the more so as an important part of them have an investment component, partly meant for the 
private business environment. Unfortunately, Romania's economic development and the post-crisis recovery have been negatively affected by the fund's slow rate of absorption. Thus, for the period 2007-2013, from the total allocated funds, the average monthly rate of absorption was just $1.06 \%$, only reaching a maximum of 3.6\% in January 2016 (Romanian Ministry of European Funds 2018). At such an average absorption rhythm, Romania needed about 100 months to achieve the absorption equal to that of a European budgetary cycle of 60 months (almost double the absorption time). Additionally, a very high volatility of the absorption rate can be noticed from one month to the next, pointing to the authorities' lack of a steady effort to ensure the proper carrying out of the local recipient projects.

For a country like Romania, where saving is not enough to support the development process and where European fund absorption is questionable, foreign investments are vital and make up for the shortages associated with development funding. Attracting direct foreign investments is a successful development funding recipe provided it is done with vision and attention. For instance, starting in 1997, South Korea's reform to attract such investments has been an example of best practice for all OECD countries, proving not only the importance of targeting investments towards priority sectors of the economy but also to be a high quality approach to investment-attracting authorities, which, in this case, can be summarized as follows: pre-announcing the reforms; planning the reforms (as a rule for 5-year periods); continuing the realistic and credible planning of announced reforms; functional forums for public dialogue, also with the foreign investors; including the process of investment attraction in a wider reform framework (Nicolas et al. 2013). In South Korea there was a vision, with a clear path where to and how to allocate the capital resources.

The level of foreign investments in Romania had a positive course yet they did not make a steady contribution to the economic growth and development. In 2016, the foreign investment contribution to Romania was like that of 1995-1996, which means that, unlike other countries in the region, no significant steps towards connecting Romania to the international capital markets were made. Moreover, a rather high speculative feature is present in these foreign investments (high volatility) and, during the crisis, their withdrawal from Romania was spectacular. It is unfortunate that, because of the lack of trust in the Romanian economy and of the perceived apparent instability, attracting foreign direct investments back in postcrisis periods is hard to achieve. This explains the low resilience of the Romanian economy and can also raise serious doubts as to the sustainability of the entire process of economic growth and development in medium and long terms.

\section{Economic Development Driven by Exports: A Mandatory Challenge for Emerging Romania}

Romania is a country where the formation of GDP was constantly based more on the exporting capacity: in 1995 the dependence of GDP from exports was only $25.5 \%$ and in 2017 this dependence had increased to $41.4 \%$ (Eurostat 2017). This increased 
capacity is due to the openness of the economy to the international capital and the international markets (especially from the European Union-Single Market).

Despite this increasing exporting capacity, the internal market and internal consumption remain the most important problems for Romania. The dependence of GDP on households' final consumption had not significantly changed over the same period: in 1995, the final consumption of households to the GDP was $81.4 \%$ and slightly decreased to $77.7 \%$ in 2017 , after a maximum of $86.2 \%$ in 2005 (Eurostat 2017). This constant significant dependence of GDP on local consumption should be correlated with the constantly increasing dependence on imports: in 1995, the weight of imports to Romania's GDP was 30.5\% and increased to $43.6 \%$ in 2017 (idem). This dependence of Romanian GDP on imports has always been higher than its dependence on exports. Moreover, the international trade deficit has always been a problem for Romania: this deficit is negative, starting from 1990 until today. This negative trade balance kept the local currency under pressure and it constantly lost purchasing power compared with foreign currencies. Romania and Poland are the countries in the region that have had a negative international trade balance for almost three decades. This high dependence on internal consumption and the increased importance of imports (higher than exports; international trade deficit not surplus) in the Romanian economy prove that local producers have a limited capacity to produce and sell for the local market. Before focusing on external markets, Romanian producers should focus more on the internal market and internal consumption. Romanian exporters should give, at least, the same importance to the local market as the external ones.

To enhance export-led economic growth, a country must develop its internal specialization by considering the possible comparative and competitive advantages, by stimulating capital allocation in the most efficient and competitive sectors and by benefiting from increased economies of scales (Jaunky and Lundmark 2016; Popa et al. 2016). Therefore, a more agile entrepreneurial activity, with a real added value to the local production, is a mandatory first step to decrease dependence on imports and to create the framework for a healthy export strategy. The value added by Romanian industry (dominated by manufactured goods such as food and beverages and vehicles, which account for $75 \%$ of the total industrial production) decreased from $38.4 \%$ in 1995 to $34.9 \%$ in 2015 (Eurostat 2017). This is due to insufficient capital investments in the economy: the gross capital formation to Romanian GDP slightly increased from $21.4 \%$ in 1995 to $22.6 \%$ in 2017 (idem).

The data on the Romanian international trade balance reveals not only the fact that in the boom phase the deficit is significantly higher but that any attempt to increase the Romanian exports is doubled by an increase in the level of imports (the dynamic of exports is highly correlated with the dynamic of imports). This situation is explained by the fact that local production is significantly dependent on the import of raw materials and spare parts (in the case of vehicles produced and exported by Romania, the engines and major components are imported from other countries). The import of technology is the second explanation: the import of machineries and tools increases every time a Romanian producer wants to increase its production and exporting capacity. 
Romanian international trade data (Eurostat 2017) reveals other important issues that are undermining a possible export-led growth strategy: an increasing dependence on Romania's exports by the European Union (which was only 37\% in 1990 and increased to $75.8 \%$ in 2017 ; this dependence is the same today in the case of imports) and a limited diversification of Romanian exports. The leading exports in 1991 were machinery and electric tools $(16 \%)$, basic products manufactured from common metals (15\%) and minerals (15\%). The leading exports in 2000 were textiles (20\%), basic products manufactured from common metals (18\%) and machinery and electric tools (8\%). The leading exports in 2017 were machinery and electric tools $(28 \%)$, vehicles $(18 \%)$ and basic products manufactured from common metals (9\%). These structural changes in Romanian exports over time reveal a constant high dependence on a very limited number of products and explain the limitations in terms of value added and the manufacturing capacity of the Romanian economy. In the last decades, Romania has continued to export basic products and raw materials and has replaced a less sophisticated lohn production (textiles and machineries/electric tools) with a more sophisticated lohn (vehicles and machineries/electric tools) that are strongly dependent on the imports of components produced elsewhere.

Therefore, an export-led growth strategy for Romania can be a successful one, but only with some changes: reducing the dependency on Romanian exports by the EU by searching for new markets for exports outside the EU; reducing the dependency of Romanian exports on the mentioned limited number of products; increasing the manufacturing level for Romanian exports by adding more production stages to basic products exported today; increasing the participation of local producers (especially Romanian SMEs) to the manufacturing and exporting activities; and stimulating the investments in the exporting capacities and continuing the efforts to promote the local products among the local consumers (to reduce the international trade deficit).

\section{Instead of Conclusions: About the Power to Restart}

The economic theory on drivers of development has continuously evolved. In the beginning, the factors considered were natural resource endowment, money accumulation and protectionism, which were soon replaced by market liberalization, capital accumulation, the theory of comparative and/or competitive advantages in the mutual exchanges, the demographic factor, industrialization, the technological factor, education, innovation, entrepreneurship and creativity, and the quality of the institutions. And then, maybe the most debated on, the state as an initiator of knockon-effect public investments. Economic development is not possible without adequate transport and telecommunication infrastructures. Among the investment priorities of the nations interested in sustainable development we should find such projects as intensifying economic activities, sustaining the addition of more production stages, getting consumers and suppliers closer to one another in the territory, and 
improving and enhancing market mechanisms. Any other kinds of investments will only turn into simple consumption and, in time, become a burden to a nation's development.

Romania finds itself in an unbalanced situation: although there is economic growth, this comes after a history of meandrous progress and does not translate, to the same extent, into welfare. Romania's population was, in 2016, 19.71 million inhabitants compared to 23.2 million in 1990 (World Bank Database 2017) due to emigration and a negative demographic growth. Thus, if in the past the country was facing problems related to employment and the development policies had to focus mostly on creating more jobs, at present the situation is no longer so black and white. To go beyond the periphery level, within which it may advance yet without catching up with the rest, the country needs investments-maybe public and very likely foreign - that are of high quality, non-speculative, and targeted towards activities with medium and long-term knock-on effects: infrastructure, cutting edge industryand not just assembling or making sub-assemblies or raw material processing. Certainly nothing is possible in the absence of real results from research-development. Innovation, a key element in development, greatly depends on the quality of the system of education and its capacity to relate to the real needs of the economy. Technology advance is not achievable or effective unless it relates constantly to the needs of the market, while innovation and research-development carried out away from the market wear out resources rather than include them in a sustainable development process. With the lowest GDP share in education spending in the EU, Romania is far from being able to step on this development pedal.

Economic growth is important for economic development but it should not be achieved at any cost or sacrifice. When economic growth is not confirmed in the general improvement of the living standard or when it widens the gaps among regions, communities or individuals even more, we cannot say that it produces economic development nor that it will last long enough without being overtaken by its downside-recession. That is why periods of economic growth that are not accompanied by higher welfare, as in the case of Romania, are only half-good news and, sadly, are not a safeguard for development.

Regardless of the way a country develops, accessible funding is needed for activities aimed at economic development. Lacking capital, no economic process, as complex as they are nowadays, can be initiated, while the failure to allocate the existing capital to economic priorities essential for the nation will confine economic development. Financial market globalization helped emerging economies as they accepted opening up to foreign capital imports (external credits, direct foreign or portfolio investments) that cover shortages in domestic capital accumulations, but, at the same time, they make such countries more vulnerable to external shocks. Romania needs a vision on development while it attracts capital for the support thereof, starting from saving stimulation to foreign investments targeted towards activities that have a knock-on effect in the economy. At the same time, it needs to enhance the quality of the public investments and to attract and use European funds more efficiently. 
There is no unique recipe for development or an optimum combination of factors that inexorably leads nations to prosperity. Each nation must uncover what suits it best according to its specificity in competitive or comparative advantages. What is certain in this case is that opening up to external markets can help tremendously in more rapidly identifying such elements and in their subsequent turning into welfare for one's own nation and not only-yet with an eye on limiting the negative effects of such opening up. And, finally, words like "policy" or "vision" need to be concretized and ensured continuity - this being, perhaps, the first condition for Romania to be able to finally move on from its peripheral position in European development.

Economic growth cannot turn into development without a clear and assumed vision to back it up. This vision needs to be made starting from understanding the context, then moving on to identifying the development drivers indicated by the various schools of thought as the most adequate for the targeted economy and which propose resource allocation towards such priorities that serve best their capitalization. Development must not be tackled chaotically; the approach needs steadiness over time and to be generally assumed by all the political forces so that no change of vision occurs every new election cycle.

\section{References}

Anghel, L., Pînzaru, F., \& Dinu, M. (2014a). Aspects of price competitiveness in the context of preparing for accession to the euro zone: New challenges for entrepreneurs. Romania's case. Management Dynamics in the Knowledge Economy, 2(3), 525-536.

Anghel, L., Pînzaru, F., \& Dinu, M. (2014b). Aspects regarding the evolution of nominal and real convergence before and after adhesion to the euro zone. In A. Roman \& S. G. Anton (Eds.), Monetary, banking and financial issues in central and eastern EU member countries: How can central and eastern EU members overcome the current economic crisis? (Vol. II, pp. 40-48). Iaşi: Editura Universității Alexandru Ioan Cuza.

European Commission. (2017). Retrieved May 12, 2017, from http://ec.europa.eu/europe2020/pdf/ csr2016/cr2016_romania_en.pdf

Global Innovation Index. (2017). Retrieved January 21, 2018, from https://www.globalinnovationindex. org/gii-2017-report

Hostiuc, C. (2017). Retrieved March 16, 2018, from http://www.zf.ro/opinii/ce-este-interesulnational-care-este-pretul-lui-si-cum-au-ajuns-supermarketurile-straine-sa-faca-politica-monetaraa-bnr-16338759

Jaunky, V. C., \& Lundmark, R. (2016). Forest products exports and economic growth: Evidence from rich countries. Journal of Developing Areas, Tennessee State University, College of Business. 50(4), 443-458.

Nicolas, F., Thomsen, S., \& Bang, M. H. (2013). Lessons from investment policy reform in Korea. Retrieved from https://www.oecd.org/daf/inv/investment-policy/WP-2013_2.pdf

Popa, I., Tudor, C., Belu, M., \& Paraschiv, D. (2016). On the role of exports for economic growth at a global level through an LMM approach. Economic Computation and Economic Cybernetics Studies and Research, 50(4), 5-24. 


\section{Online Sources}

Eurostat. (2017). Retrieved November 10, 2017, from https://ec.europa.eu/eurostat/data/database INS - National Institute of Statistics. (2017). Retrieved November 11, 2017, from http://statistici. insse.ro:8077/tempo-online/\#/pages/tables/insse-table

Romanian Ministry of European Funds. (2018). Retrieved April 21, 2018, from http://www. fonduri-ue.ro/

World Bank Database. (2017). Retrieved November 22, 2017, from https://data.worldbank.org/

Open Access This chapter is licensed under the terms of the Creative Commons Attribution 4.0 International License (http://creativecommons.org/licenses/by/4.0/), which permits use, sharing, adaptation, distribution and reproduction in any medium or format, as long as you give appropriate credit to the original author(s) and the source, provide a link to the Creative Commons licence and indicate if changes were made.

The images or other third party material in this chapter are included in the chapter's Creative Commons licence, unless indicated otherwise in a credit line to the material. If material is not included in the chapter's Creative Commons licence and your intended use is not permitted by statutory regulation or exceeds the permitted use, you will need to obtain permission directly from the copyright holder. 


\title{
"Nous Choisissons L'Europe": EU's Economic Development and Current Challenges
}

\author{
Clara Volintiru and Gabriela Drăgan
}

\section{Introduction}

Undoubtedly, the EU is at a new crossroads. Although reform is inevitable, the way to be chosen is still under scrutiny. The Union's reform scenarios, advanced by the European Commission in March 2017, indicate the existence of at least five possible directions of evolution by 2015: maintain the current situation (scenario 1: Carrying on); returning to a previous integration stage (scenario 2: Nothing but the single market); improve the current situation and deepen the integration process (scenario 5: Doing much more together); or initiate radical changes in the functioning of the EU (scenario 3: Those who want more do more and scenario 4: Doing less more efficiently). Each of these five scenarios emphasizes the need for urgent reform of the EU institutions and policies and the inevitable impact of reforms (and Brexit) on the next EU budget. ${ }^{1}$

Whatever EU institution and policy reform solutions are chosen, the urgency to reform the EU as a whole has left the European economy with little room to

Bruno Le Maire, French Minister of Economics, public interview 05.10.2017, http://www. parismatch.com/Actu/Politique/Bruno-Le-maire-Nous-choisissons-1-Europe-contre-la-Chineet-les-Etats-Unis-1363628, last accessed 27.01.2018.

${ }^{1}$ European Commission, White Paper on the future of Europe. Reflections and scenarios for the EU27 by 2025, available on https://ec.europa.eu/commission/sites/beta-political/files/white_paper_ on_the_future_of_europe_en.pdf, last accessed 31.01.18.

C. Volintiru ( $\square)$

Bucharest University of Economic Studies, Bucharest, Romania

e-mail: clara.volintiru@ rei.ase.ro

G. Drăgan $(\bowtie)$

Bucharest University of Economic Studies, Bucharest, Romania

European Institute of Romania, Bucharest, Romania

e-mail: gabriela.dragan@ier.gov.ro 
manoeuvre. Although, according to the Autumn 2017 Economic Forecast, the EU economic recovery, supported by resilient private consumption, stronger global growth and falling unemployment recorded the fastest pace in the last decade (2.3\% in the EU and $2.2 \%$ in euro area) and predicted trends are also favourable (a trend that is expected to continue in the next years in both the euro area and the EU (2.1\% in 2018 and $1.9 \%$ in 2019)), internal and external risks could affect the pace of EU economic growth in the short and medium-term. Primarily, internal risks are related to the outcome of the Brexit negotiations, the evolution of public finance and populist movements in different EU member states, while the main external risks are linked to the new geopolitical tensions (from the Middle East to North Korea), the extension of protectionist measures (see, among others, some of Donald Trump's latest declarations) and, last but not least, significant economic adjustments in China.

In fact, on the global market, the EU position appears to be increasingly fragile and exposed to multiple risks. Thus, the EU's share in the global GDP is rapidly shrinking, from 31.4\% in 2004 to $23.8 \%$ in 2014, while the Unites States has moved from $28.1 \%$ to $22.2 \%$. Meanwhile, the Chinese share of world GDP has risen very rapidly: from $4.5 \%$ to $13.4 \%$, moving ahead of Japan $(5.9 \%$ in 2014$) .^{2}$ The same evolutions are evident in terms of international trade, where China's share in global exports has risen from $3.1 \%$ in 2000 to $13.6 \%$ in $2016 .{ }^{3}$ Moreover, as Glenn and Sweeney noticed, China's share in global exports is "the highest share any country has enjoyed since the United States in 1968", 4 a success that contradicts the "widespread predictions that rising costs for Chinese labour and a currency that has increased nearly $20 \%$ against the dollar in the last decade would cause China to lose market share to cheaper competitors". The Economist (2017), analysing China's position on international competition, notices that though this country is not the first in the process of industrialisation, "none has ever made the leap so rapidly and on such a monumental scale". While a "decade ago Chinese boom towns churned out zips, socks and cigarette lighters (...), today the country is at the global frontier of new technology in everything from mobile payments to driverless cars". 5

Since China's rapid growth has changed both the global rules of the game and recalibrated the position of developed and developing countries on the international market, and internally the economic crisis has profoundly affected the EU growth engines, the only realistic option for the EU is to rethink its model of development

\footnotetext{
${ }^{2}$ Eurostat, The EU in the world: economy and finance, http://ec.europa.eu/eurostat/statisticsexplained/index.php/The_EU_in_the_world_-_economy_and_finance, last accessed 31.01.18.

${ }^{3}$ World Trade Organisation (WTO), Annual Report, 2001, p. 20, https://www.wto.org/english/res_ e/booksp_e/anrep_e/wto_anrep01_e.pdf, World Trade Organisation (WTO), Annual Report, 2017, https://www.wto.org/english/res_e/booksp_e/anrep_e/anrep17_e.pdf, last accessed 31.01.18.

${ }^{4}$ Elias Glenn, Pete Sweeney, China seizes biggest share of global exports in almost 50 years, Reuters, Business News, April 22, 2016, https://www.reuters.com/article/us-china-exports/chinaseizes-biggest-share-of-global-exports-in-almost-50-years-idUSKCNOXJ097, last accessed 31.01.18. ${ }^{5}$ The Economist, How China is battling ever more intensely in world markets. But does it play fair?, 23 September 2017, https://www.economist.com/news/leaders/21729430-does-it-play-fair-howchina-battling-ever-more-intensely-world-markets, last accessed 31.01.18.
} 
and reform its policies and institutions by deepening the interdependencies among member states. The EU 4.0 revolution is not only a possible option but a mandatory choice.

\section{Economic Survival Strategies for EUROPE 4.0}

\subsection{Crisis Hits: First Aid Kit}

The economic crisis that started at the end of 2007 in the USA and the beginning of 2008 in the EU had by all accounts a different impact on the two regions. This can be easily explained by the different governing structure. The US government was able to take political action swiftly to deal with the aftermath of the financial bubble, while the hybrid political ecosystem of the EU had to deal with numerous tensions between the diverging interests of the member states. While periphery states such as Greece, Italy and Portugal preferred to manage the economic crisis from a social economic model targeting record high unemployment, the wealthy core of the Eurozone (e.g. Germany, the UK) opted for austerity measures as the prescribed solution to curb governmental debt. In contrast, the United States opted for "quantitative easing" measures that essentially meant printing more money, but they also helped the housing market to recover ${ }^{6}$ as well as keeping unemployment at bay. The deficit problems may be solved by the Eurozone's approach to the crisis but the longterm damage of extremely high youth unemployment (up to $50 \%$ in some periphery countries) and growing inequalities ${ }^{7}$ is not being addressed. In this context, the positive effects of economic growth might no longer be distributed to all European citizens.

A European Central Bank assessment after the financial crisis warned that "the global economy continues to be exposed to the risk of a creeping return of trade protectionism", and as Georgiadis and Gräb found, countries "pursue more traderestrictive policies when they experience recessions and/or when their competitiveness deteriorates" (2016, p. 1). Knetter and Prusa (2003), Bown (2008) and Bown and Crowley (2013) all point to the negative correlation between losses in competitiveness or economic decline and the likelihood of a country adopting anti-dumping measures.

Most evaluations of losses in competitiveness or economic slowdown take into consideration the real exchange rates. This is a useful methodological approach for large $\mathrm{N}$ datasets but we can equally assess the decline of competitiveness at case

\footnotetext{
${ }^{6}$ Mark Weisbrot, Why has Europe's economy done worse that the US?, 16 January 2014, https://www.theguardian.com/commentisfree/2014/jan/16/why-the-european-economy-is-worse, last accessed 10.02.2018.

${ }^{7}$ European Commission. Competitiveness in low-income and low-growth regions: The lagging regions report. 10 April 2017. http://ec.europa.eu/regional_policy/sources/docgener/studies/pdf/ lagging_regions\%20report_en.pdf, last accessed 10.02.2018.
} 
study level through various changes in the performance of economic agents. As the global financial crisis swept across the Western world, companies saw their profits diminish while governments resorted to austerity measures. Some authors have strongly critiqued the capacity of the austerity measures to reignite a growth tendency in the economy, amongst whom the strongest has been Mark Blyth (2013). Even in the absence of austerity measure, the European Union has made a clear emphasis on downsizing inward protectionism such as state subsidies and state aid. In this context, we can see how large-scale producers in Europe are facing the double constraint of a declining consumption capacity in the domestic market and less state intervention in their favour.

The European Union was built on what was initially called the European Coal and Steel Community (ECSC), which was established upon the proposition of the French foreign minister Robert Schuman in 1951. Looking back on the industries that lay at the foundation of the EU, the context could not be more different. The Third Report on the State of the Energy Union ${ }^{8}$ stated clearly that the days of the coal industry are numbered as closure aids are granted to member states in the fast-paced transition process towards a clean energy economy. In contrast, the downturn of the steel industry is not yet a foregone conclusion.

According to official trade statistics, the top importers of iron and steel worldwide are Germany with $\$ 23$ bil., United States of America with $\$ 22$ bil., China with $\$ 17$ bil., Italy with $\$ 14$ bil., and South Korea with $\$ 14$ bil. Similarly, the top exporters of iron and steel worldwide are China with $\$ 43$ bil., Japan with $\$ 24$ mil., Germany with \$21 mil., South Korea with \$19 mil. and Russia with \$14 mil. Together, the EU market represents almost $40 \%$ of the worldwide imports or exports of iron and steel.

The steel industry is relevant on many accounts to the European economy. International trade revenues are only part of the story. Equally important is the scale of employment in this sector. Currently there are approximately 300,000 people in direct employment in steel refineries across member states, and one could expect a matching figure for those in dependent or indirect employment. It is true that the number of employees in this sector is significantly lower than a decade or two ago. The decrease of the number of employees however is not only related to a decrease in domestic consumption and delocalisation processes. Technological advances are one of the driving factors in the lowering levels of labour intensity in many industrial sectors, not just steel. Finally, the steel industry is relevant to the European economy not by itself but also because of its contribution to two of the most competitive sectors in the EU: the automotive and construction industries. Very early on, given the increased economic integration driven by WTO negotiations, the European Union placed its global competitiveness aspirations on the back of highervalue products and services, where it could retain an advantage in the face of emerging markets with larger economies of scale than its own. ${ }^{9}$

\footnotetext{
${ }^{8}$ European Commission (2017) Third Report on the State of the Energy Union, available at: https:// ec.europa.eu/commission/publications/third-report-state-energy-union_en, last accessed 22.01.18.

${ }^{9}$ European Commission (2006) Global Europe: Competing in the World, A Contribution to the EU's Growth and Jobs Strategy. http://trade.ec.europa.eu/doclib/docs/2006/october/tradoc_130376.pdf
} 
Protectionist measures nowadays take many forms so as to escape the commonly agreed upon liberalization framework. One form of defensive protectionist measures is the anti-dumping regulation aimed at addressing the unjust imbalances in the world trade. As such, the European Union and the United States have throughout 2017 seen a sustained campaign against the steel imports from China that many believe are sold at dumping prices. It is not hard to imagine that in the regulatory context in which the Chinese economic actors operate, the state-owned enterprises (SOEs) that are active in this sector benefit from state support in the form of subsidies or preferential interest loans. On this ground, the EU has imposed antidumping measures in this sector while the US is challenging the market economy status of China at WTO. These actions are consequential not only in terms of protecting a strategic economic sector but also in terms of the larger cooperation in trade liberalisation at the global level.

The multilateral system of cooperation that saw the inclusion of China in 2001 and Russia in 2012 in WTO seems to be counterbalanced by regional and bilateral approaches nowadays. In the aftermath of the financial crisis, the European Union has been much more successful in pushing through bilateral trade and investment partnerships with neighbours (e.g. Eastern Partnership countries-Ukraine, Georgia and the Republic of Moldova) and historical partners (e.g. Canada) than multilateral rounds of negotiations within the WTO format.

\subsection{Lagging Behind in Consumption}

The decline of the single market's capacity is not solely based on economic cycles and recessions. Throughout the past decades, the population in the European Union member states has been recording a steady downward trend. For some countries, especially in Southern, Central and Eastern Europe, an important factor in the demographic decline is emigration. Eurostat data (2017) shows the migration patterns within the European Union begin from the crisis-affected countries in the South or the poorer regions in the East and head mainly towards Germany, which has been additionally targeted heavily by outside migrants. Still, across Europe, low birth rates are the primary causal factor of the population decline. Increases in lifeexpectancy have also increased the median age of the population, leading to what is frequently referred to as the "greying Europe".

The "demography crisis" with the well-known ageing of the population is not only relevant from the perspective of the burden it applies on social security expenditures and, more specifically, pension funds (Vasile et al. 2012), it also has a profound impact on the relative positioning of the European economy as a whole from the perspective of the downsizing consumer market. In a recent study on this topic, a Romanian economist looks at the car sales data across the world as a proxy for middle-class purchasing capacity (Silva 2017). Based on the International Organization of Motor Vehicle Manufacturers (OICA) reports, the European Union has levelled at a total purchasing of approximately 15 mil. personal cars yearly-this has 
been relatively constant across the past decade, with a slight decrease after the financial crisis of 2008. Similarly, the United States recorded approximately 11 mil. personal car sales in the past decade. In contrast, Asia reached approximately 40 mil. personal car sales, out of which approximately 25 mil. are sold only in China-recording a five-fold increase since 2005.

The sharp difference between the Western powers and Asian economies in the volume and historical trends of consumption is a sombre reminder that the economic growth of the European Union member states can only be achieved through innovative development strategies. According to the latest Global Competitiveness Report (2017-2018), EU economies have improved their innovation capacity over the past decade (especially Germany, Netherlands and Sweden), but as a whole still trails behind the United States, Japan and Israel.

For the European Union, consumption is an ambivalent point of reference. On one hand, much like in many developed economies across the world, household consumption represents an important driver of economic growth measured in gross domestic product (GDP) increases. In the EU, household consumption represents roughly $60 \%$ of GDP (almost three times higher than governmental consumption). Still, in the context of an cumulative effort of approx. 5 bil. EUR for the current financing period devoted to the transition to a clean and sustainable economy, we see consumption patterns coming under the scrutiny of these new environmental goals. ${ }^{10}$

\subsection{Economic Drivers}

A quarter of the European Union's trade with outside partners is realised by Germany alone (see Fig. 1). It has a positive trade balance, meaning that it exports more than it imports. It has seen a slight decrease over the past years, from a total exports annual value of $\$ 1.4$ bil. in 2012 to $\$ 1.3$ bil. in 2016 . This however follows the overall trend of the main trade powers in the European Union: France, Italy, Netherlands, the United Kingdom and Belgium. All top traders in the European Union have been colonial powers, with the exception of Germany, which, incidentally or not, outperforms them by far. The status of former colonial powers is important even within the context of the European Union because the preferential trade relations with the former colonies (e.g. favourable tariffs on imported goods) were granted since the Treaty of Rome under French pressure and Belgium's and the Netherland's support (Dinan 1999).

One of the main elements of the trade performance of Germany is its own market. As we can see from the two graphs showed above, while lower than its exports

\footnotetext{
${ }^{10}$ European Commission (2011) 571 final, Roadmap to a Resource Efficient Europe http://ec. europa.eu/environment/resource_efficiency/about/roadmap/index_en.htm; A /RES/66/28 (2012) UN General Assembly resolution 66/288, The future we want. http://www.un.org/en/develop ment/desa/population/migration/generalassembly/docs/globalcompact/A_RES_66_288.pdf
} 
EU Exports by country of origin, mil. \$

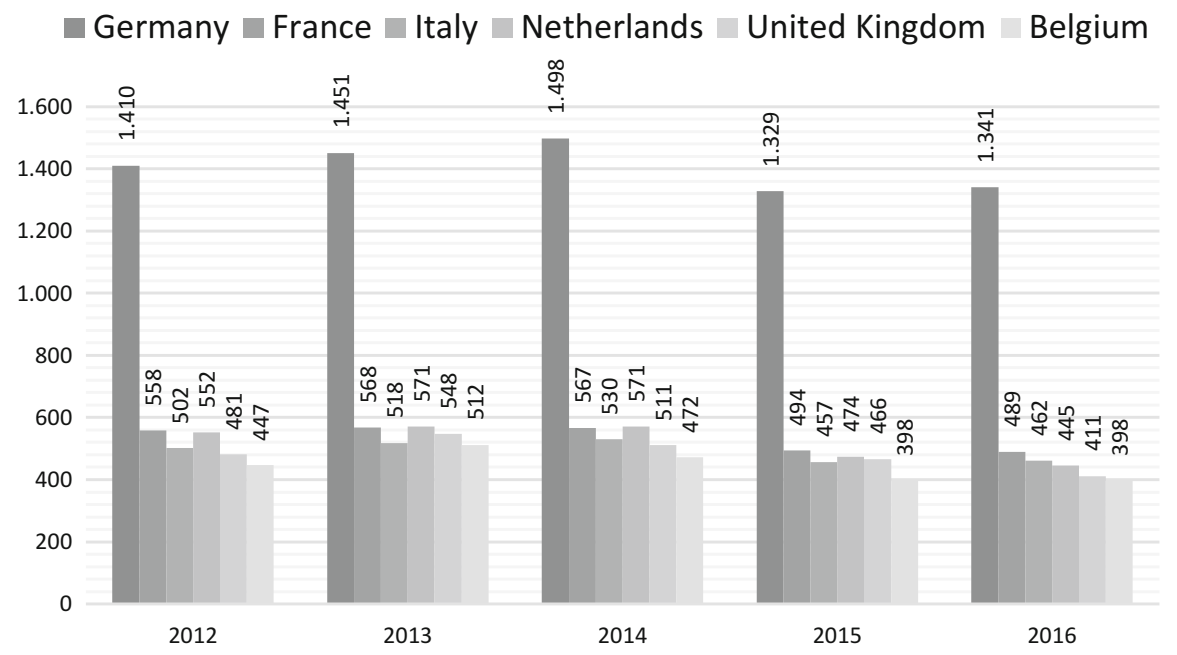

Fig. 1 EU exports by country of origin. Source: Adapted by the authors based on data from trademap.org

levels, German imports are still almost double the value of French imports, the second-ranked importer in the European Union (see Fig. 2). The relatively high purchasing power of private sector and household consumers in Germany is granted by a well-balanced developmental model, labelled as "social-market capitalism" (Gilpin 2001) or soziale Marktwirtschaft, that combines the free market principles with economic policies designed to support the general development of the economy (e.g. monetary, trade or fiscal). As a result, we can see that the German economy meets both social indicators that portray the general welfare of the population as well as competitiveness landmarks. It has some of the largest multinational companies in the world while also having a large and dynamic SMEs sector. Sustained economic growth in Germany is also maintained through technological innovation, having substantial public and private funding allocated in this direction, and high valueadded products as a result.

The main economic products with which Germany dominates global markets are: vehicles other than railway or tramway rolling stock, and parts and accessories thereof $-18 \%$ of world exports, largest exporter globally; machinery, mechanical appliances, nuclear reactors, boilers-12\%, ranked second-largest exporter globally, pharmaceutical products-16\% of world exports, largest exporter of this product globally, and other technological intensive products such as aircraft and electrical machinery.

Despite the current snapshot, the European top exporters are losing ground in sectors that are growing at global level. This is mostly due to the increasing competitiveness of multinational companies in emerging markets. As such, a series 
EU Imports by country of destination, mil. \$

\section{$\square$ Germany $\square$ United Kingdom $\square$ France $\square$ Italy $₫$ Netherlands $₫$ Belgium}

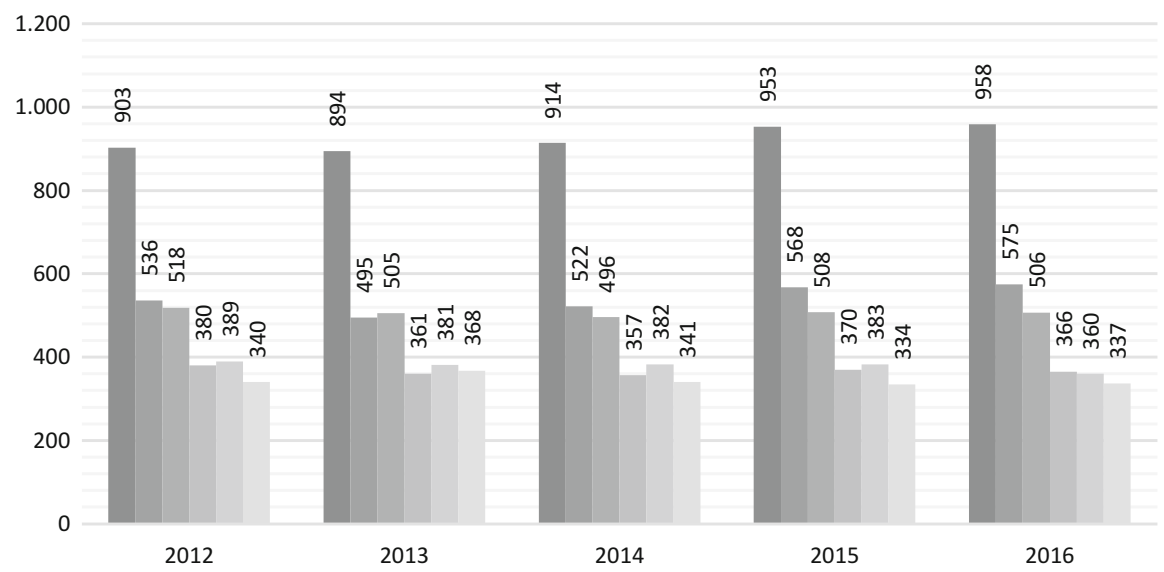

Fig. 2 EU imports by country of destination. Source: Adapted by the authors based on data from trademap.org

of reactions have been recorded recently in Western Europe. France, Germany and Italy presented a public letter in 2017 amid concerns over the size of Chinese investments in European state-owned enterprises (SOEs). They claimed that "a growing number of non-EU investors were buying up European technologies for the strategic interest of their home country" ${ }^{11}$ The large Chinese investment through its state-owned COSCO company in the Piraeus port of Greece last year is only part of a larger-scale investment plan across the EU and it Balkan periphery. In response, a series of mergers, acquisitions and "alliances" have been launched amongst Western European states to consolidate their European position. Saint-Nazaire has teamed up with the Italian Group Fincantieri and Alstom, the state-controlled producer of TGVs, has teamed up with the German company Siemens and they are reportedly on track to introducing autonomous trains on the market. The stated goal of this latter fusion is to "create a new European champion that is big enough to take over the world leader CRRC of China". ${ }^{12}$ As state participation in French companies is currently valued at over $\$ 100$ bil., we might expect future consolidation moves amongst the founding members of the European Union in the near future.

\footnotetext{
${ }^{11}$ Le Guernigou, Yann; Thomas, Leigh. France, Germany, Italy urge rethink of foreign investment in EU. 14 February 2017, Reuters, https://www.reuters.com/article/uk-eu-trade-france/france-ger many-italy-urge-rethink-of-foreign-investment-in-eu-idUKKBN15T1ND?il=0, last accessed 27.01. 2018.

${ }^{12}$ EU signals big asset sales to greenlight Alstom-Siemens tie-up, Financial Times, 27 November 2018, https://www.ft.com/content/a0383fae-f18f-11e8-9623-d7f9881e729f, last accessed 27.11.18.
} 
As we can see from the comparative figures on export competitiveness and relative growth, Eastern Europe and Central Asia are in a marked downturn compared to world export growth. In contrast, East Asia is performing above global growth trends (see Fig. 3). As the European Union is highly integrated through a common trade policy, the slowdown in parts of it can have widespread repercussions. The poor trade competitiveness of Eastern European markets as well as the Eastern Partnership countries with which it recently established Deep and Comprehensive Free Trade Areas (DCFTAs) (i.e. Moldova, Ukraine, Georgia) can be a significant challenge for sustainable growth. The EU's engagement in increasingly bilateral trade relations with close historical or neighbouring partners (e.g. CETA-with Canada, TTIP — with the USA, DCFTA — with Eastern Partnership (EaP) countries) can be seen as a clear disengagement from multilateral trade integration efforts. Given the economic figures of export competitiveness compiled by the World
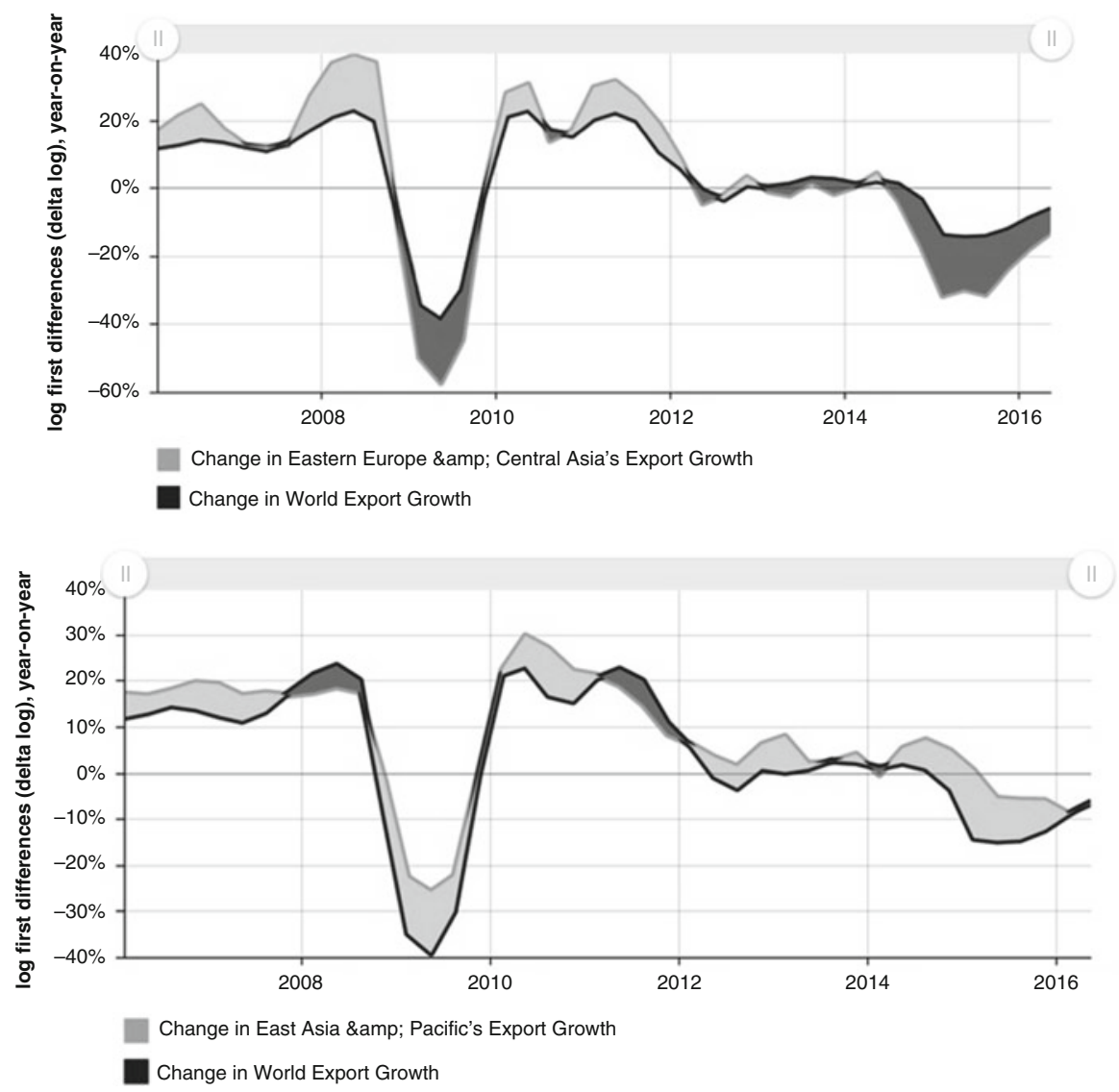

Fig. 3 World exports and change in export market share (region growth minus global growth). Source: World Bank, https://mec.worldbank.org/export-growth/ECA 
Bank, the EU's detachment from other markets that are experiencing strong growth trends might be a vulnerability for the European economy in the long term.

Approximately 30 mil. persons are employed throughout the European Union in the manufacturing sector, which makes it responsible for $15 \%$ of total employment in the EU, and approximately EUR 1700 bil. of value added annually. Nevertheless, in the majority of manufacturing sectors in which Europe is export- competitive the value-added is greater than the employment levels (e.g. manufacture of machinery and equipment, manufacture of motor vehicles, manufacture of electrical equipment, manufacture of chemicals and chemical products). Part of the downturn of Eastern European markets in export competitiveness can be explained by their lowering production in these higher value-added manufacturing sectors. Out of the top 10 European manufacturing companies, 8 are German-3 are in the automotive industry, 2 in engineering, 1 in chemicals and 1 in aerospace and defense. While employment levels are high in such areas as the manufacture of textiles and furniture, their value added is much lower.

\subsection{Trade Relations with Historical Partners: Implications for Brexit}

The European Union is increasingly represented as a single unit, from statistical repositories (almost all relevant databases have a EU 28 category) to international trade deals. In recent transatlantic negotiations, such as the CETA and TTIP, the European Union was the counterpart given the exclusive competencies of the trade policy, but national and local interests differed significantly. The unitary approach of the EU in international economic affairs is not an easy feat. The subnational differences reflect the well-known challenges of multi-level governance (Hooghe and Marks 2001), the significant divides across European regions, as well as the political posturing that creates tensions in multi-level game diplomatic efforts (Putnam 1988). Amongst all of these structural challenges, we currently find the additional element of unsteadiness: the potential exit of Britain (i.e. Brexit) from the European Union.

As seen in the previous section of this contribution, the status of colonial powers and the worldwide coverage this implied correlates with modern-day economic trade performances. What is important beyond current economic ties is also the process through which the former metropoles have become detached from their periphery and embedded their power aspirations in the European Union. Some authors point to the sobering effect the Suez crisis had on the relative self-projections of European powers (Hansen 2002) as it was in this context that France really became committed to the European Community negotiations and the Treaty of Rome (Young 1996; Anderson 1997). Nevertheless, no European Empire was more focused on trade and economic relations between the centre and the periphery than the British Empire. 
Before and after the Referendum in Britain on the question of its EU membership, the Commonwealth was largely referred to in public discourse as a substitute for the EU market. Called by many analysts the Empire 2.0 strategy, at the end of a dedicated Summit in 2017 on the trade relations between Britain and its former colonies, Patricia Scotland, the Commonwealth Secretary, stated: "Because we share common law, common language, common institutions and common parliamentary structures, that has given us a de facto advantage". ${ }^{13}$

Over half of the United Kingdom's imports came from the European Union over the past decade, but less than half of its exports go to the European Union in return. In contrast, less than a tenth of its trade is engaged with the 49 Commonwealth markets that do not belong to the European Union (i.e. Cyprus and Malta). Overall, the value of the trade between the United Kingdom and its former colonies represents only $16 \%$ of the value of the trade between the United Kingdom and other member states. One of the reasons the trade potential with the Commonwealth states is so overrated is that there are some very large markets in this set of countries judging by population level. If we look at only the top 8 countries by population in the Commonwealth, ${ }^{14}$ we find a total of approximately 2 billion persons. In contrast, the entire European Union has only half a million people. Still, even though we can count Canada and Australia amongst the most developed nations, and some of the most dynamic emerging markets such as India and Singapore, the Commonwealth is largely comprised of small, poor states. The geographical distance between UK and them is an additional impediment for trade (Fig. 4).

Out of the total $\$ 1.3$ trillion global market, a fifth of worldwide exports of vehicles other than railway or tramway rolling stock, and parts and accessories thereof is done by Germany, followed by non-European economies such as Japan, the United States of America, Mexico, Canada and South Korea. Germany exported a total value of $\$ 235$ bil. worth of vehicles worldwide in 2016, out of which it exports between $\$ 62$ and 66 bil. annual value of this product to the United Kingdom alone.

\section{Perspectives}

European member states can no longer be relevant international actors by themselves. Their strength and developmental perspectives are intrinsically linked to each other. As the political turmoil spreads from one country to another, taking various shapes and arguements, the economic reasoning behind the existence of the European Union is clearer than ever. Evidently, when we analyse trade data we can

\footnotetext{
${ }^{13}$ Roberts, Dan. Drive to replace UK-EU trade links with closer ties to Commonwealth. 10 March 2017, The Guardian https://www.theguardian.com/global-development/2017/mar/10/drive-toreplace-eu-trade-links-with-closer-ties-to-commonwealth-economies, last accessed 27.01. 2018.

${ }^{14}$ India, Pakistan, Nigeria, Bangladesh, South Africa, Canada, Ghana and Australia.
} 


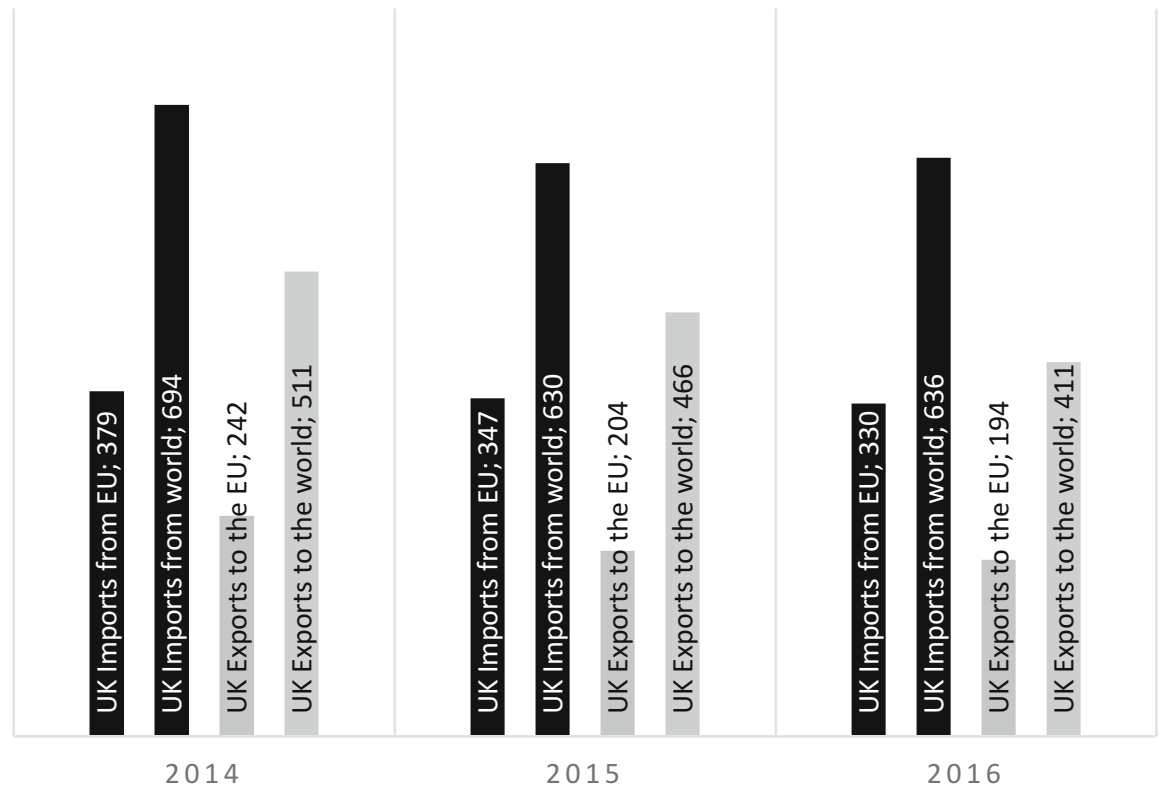

Fig. 4 UK trade balance

clearly see that the sum of the parts is not the same as the single market itself. The existence of a large "internal market" constitutes a significant advantage, even to a large market like Germany. However, it is clear that not even Germany, the "trade champion" of the European Union, can afford to rely solely on the internal market consumption. Asian markets are growing at a much faster pace than European ones, driven primarily by the larger consumption patterns based on population figures. With a sharply declining population in many European member states, the gains of the single market in trade will become smaller and smaller.

As this chapter points out, there are no value-similar alternatives to the European Union for Western powers. At the beginning of the integration process, the historical peripheries of the colonial power still played a somewhat important role in their trade and development, which is why preferential relations were established from the very beginning with these states. However, as the globalization process progressed and the single market developed, the value of intra-EU trade relations and extra-EU trade relations is incomparable. Taking the Brexit context as a test case, we compared the United Kingdom's trade relations with EU member states and Commonwealth partners. Despite public rhetoric and political discourse, the evidence is clear: the latter is less than a fifth of the first. As such, any decision to cut away or distance itself in any way from the EU core would only involve a significant risk to the economic growth of any European country. 


\section{References}

Anderson, P. (1997). Under the sign of the interim. In P. Gowan \& P. Anderson (Eds.), The question of Europe (pp. 51-76). London: Verso.

Blyth, M. (2013). Austerity: The history of a dangerous idea. New York: Oxford University Press.

Bown, C. P. (2008). The WTO and antidumping in developing countries. Economics and Politics, 20(2), 255-288.

Bown, C. P., \& Crowley, M. A. (2013). Import protection, business cycles, and exchange rates: Evidence from the great recession. Journal of International Economics, 90(1), 50-64.

Dinan, D. (1999). Ever closer union: An introduction to European integration (2nd ed.). Basingstoke: Macmillan.

European Commission. (2006). Global Europe: Competing in the world - A contribution to the EU's growth and jobs strategy. COM/2006/567/FINAL.

European Commission. (2011). Roadmap to a resource efficient Europe. COM/2011/0571 final.

Georgiadis, G., \& Gräb, J. (2016). Growth, real exchange rates and trade protectionism since the financial crisis. Review of International Economics, 24(5), 1050-1080.

Gilpin, R. (2001). Global political economy: Understanding the international economic order. Princeton, NJ: Princeton University Press.

Hansen, P. (2002). European integration, European identity and the colonial connection. European Journal of Social Theory, 5(4), 483-498.

Hooghe, L., \& Marks, G. (2001). Multi-level governance and European integration. Lanham, MD: Rowman \& Littlefield.

Knetter, M. M., \& Prusa, T. J. (2003). Macroeconomic factors and antidumping filings: Evidence from four countries. Journal of International Economics, 61(1), 1-17.

Putnam, R. D. (1988). Diplomacy and domestic politics: The logic of two-level games. International Organization, 42(3), 427-460.

Silva, D. (2017). Das book: On growth and development. Romania: Cluj-Napoca. http://dansilva. ro/wp-content/uploads/DasBook_FINAL.pdf

Vasile, V., Tache, I., Tudor, C., \& Volintiru, C. (2012). The analysis of the evolution of EU social policies in the last three years - Supplementary/private pensions and the impact of an ageing population (No. 2011, 4). Bucharest: European Institute of Romania, Strategy and Policy Studies (SPOS).

Young, J. (1996). Cold war Europe 1945-1991: A political history (2nd ed.). London: Arnold.

Open Access This chapter is licensed under the terms of the Creative Commons Attribution 4.0 International License (http://creativecommons.org/licenses/by/4.0/), which permits use, sharing, adaptation, distribution and reproduction in any medium or format, as long as you give appropriate credit to the original author(s) and the source, provide a link to the Creative Commons licence and indicate if changes were made.

The images or other third party material in this chapter are included in the chapter's Creative Commons licence, unless indicated otherwise in a credit line to the material. If material is not included in the chapter's Creative Commons licence and your intended use is not permitted by statutory regulation or exceeds the permitted use, you will need to obtain permission directly from the copyright holder.

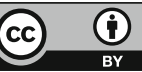




\title{
European Imbalances: The Sound and the Fury
}

\author{
Jérôme Creel
}

\section{Introduction}

The European crisis has gathered much attention. The double-dip recession and then the slow recovery process have shaken the European process of economic and monetary integration and even raised doubts on the survival of the Euro, the single currency of 19 out of 28 member states of the European Union (EU). The Brexit decision taken by the British citizens and their government in 2016 followed by the Catalan crisis in Spain in 2017 are the visible political parts of the iceberg that hit the EU. Threats to the European process, via relatively bad economic performance, have generated many explanations, some exclusive, some interrelated.

The first objective of this chapter is to review these explanations in a critical manner. The second objective is to draw a comprehensive view about European economic difficulties - I will call them European imbalances-and discuss different policy strategies to fix them.

Two forewords are important at this stage. First, the chapter will deal explicitly neither with political issues - they are implicitly involved in the different explanations-nor with the political feasibility of reforms. Consequently, some of the reforms I will evoke here can be thought as directions for reforms rather than reforms per se. Second, the directions for reforms presented here are the outcome of a larger

This contribution draws on the keynote speech I prepared for the conference Strategica organized by the Faculty of Management from the National University of Political Studies and Public Administration (SNSPA) and the Romanian Academic Society of Management (SAMRO) with the support of the National Bank of Romania, in Bucharest in September 2017. I thank the participants and an anonymous referee for their remarks and George Papaconstantinou for his insightful comments.

J. Creel $(\bowtie)$

Observatoire français des conjonctures économiques (OFCE, Sciences Po), Paris, France

e-mail: jerome.creel@ sciencespo.fr 
project, the independent Annual Growth Survey (iAGS), to which I will refer in due course.

The title, in reference to the novel by William Faulkner, The sound and the fury (Jonathan Cape and Harrison Smith Publisher, 1929), may seem weird in a volume of economics and statistics. Nevertheless, the different narratives of the European crisis mirror the different levels of consciousness of the narrators in the novel. In it, we read the story of the Compson family and its fall through the eyes of the three brothers: Benjy, the disabled, Quentin, the intelligent, and Jason, the cynical; before a neutral and external narrator takes the lead and focuses on Dilsey, the servant. Thus, there are four different views in the book: a flawed one by Benjy, a disastrous one by Quentin, a cynical one by Jason, and an omniscient view by an external narrator. The latest view is the most comprehensive as it depicts the Compson family's story without embracing an intimate feeling.

The following will draw on these four views. The first part will deal with the flawed view according to which imbalances in public finances generated the European crisis. Although it has not been stated that bluntly, the recommendations which followed the European crisis are consistent with this view. The second part will relate the European crisis to a balance-of-payment crisis, a disastrous view. The third part will discuss labor market issues and nominal and real divergence across the Eurozone member states. I label this view a cynical view. The fourth part will adopt a comprehensive view: fiscal and current account imbalances are related and feed divergence. Finally, fixing these imbalances requires a comprehensive agenda for reforms on the fiscal side, but not only. Against this backdrop, I will discuss the recent reform proposals. Moreover, I will briefly argue that symmetric cooperation should prove important in delivering an optimal Eurozone.

Before presenting these views, let me briefly sketch the imbalances. Under a macroeconomic perspective, there are at least three main imbalances in the Eurozone. The first one is certainly the unemployment situation and, with it, the growth situation. In 2016, the unemployment rate reached $10 \%$ of the labor force in the Eurozone, and $9.4 \%$ in the EU. Though it has decreased after peaking at, respectively, 12 and $11 \%$ in 2013 in the Eurozone and the EU, the unemployment rate remains high-it is still, respectively, 2.5 and $1.5 \%$ points above its lowest in 2008 - and it fuels income, social, and geographical inequalities across regions and countries. The second imbalance relates to public finances. Since 2007, the ratio of public debt to GDP has increased by $25 \%$ points in the Eurozone following the large deficits that governments accumulated to dampen the global financial crisis (GFC). The third imbalance is the large current account surplus of the Eurozone vis-à-vis the rest of the world. In 2015, the Eurozone had a current account surplus of $3 \%$ of its GDP.

Against the backdrop of these imbalances, the economic performance of the EU and the Eurozone remains subdued. Figure 1 shows the evolution of the GDP growth rate since the birth of the euro in 1999. It is striking that the average between 1999 and 2007 is still higher than the recent data (2015 and 2016) despite the sharp recession of 2009 and the recession of 2012-2013. This is evidence of a slow recovery. 


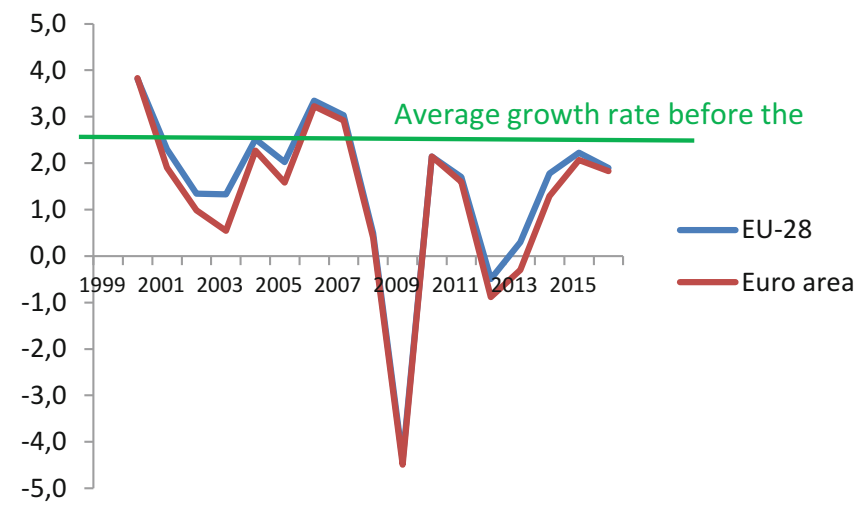

Fig. 1 Eurozone and EU GDP growth rate (in \%). Source: Eurostat https://ec.europa.eu/eurostat/fr/ home, date of access 20 September 2017

Another piece of evidence is the inflation rate. Although the European Central Bank has been implementing an expansionary monetary policy since March 2015 through massive purchases of public sector bonds, the consumer price index (including the prices of volatile materials like oil) has been almost continuously moving below the target of close to $2 \%$. In September 2017, the inflation rate lay at $1.5 \%$. Last, the slowdown in labor productivity has been quite substantial in the Eurozone and in the EU, from an average growth rate of $1.3 \%$ and $1.8 \%$ for the Eurozone and the EU, respectively, between 1999 and 2007 to an average of $0.8 \%$ for both since 2008 (source: OECD).

\section{The Flawed View}

The European sequel of the GFC has been frequently labelled a "European sovereign debt crisis". Checking on Google Scholar gives almost 300,000 results. The paper by P. Lane (2012) published under this title has been cited more than 700 times since 2012.

P. Lane does not attribute the European crisis explicitly to public debt issues and he argues for comprehensive EU reforms beyond fiscal policy, like the endorsement of a banking union. That said, the very choice of the label, "sovereign debt crisis", gives a clear idea of the culprit: governments.

There have been three phases in the evolution of public debt since 1999. First, before the GFC, debts were not high on average but there were substantial differences between Germany, France, and Spain, on the one hand, and Greece, Italy, and Portugal on the other hand. These differences fueled idiosyncratic fiscal risks in the Eurozone, between a core with stable or declining debt-to-GDP ratios and a periphery with growing debts. The onset of the crisis led to sharp increases in public debt in all Eurozone countries, giving way to the second phase. It also led to a break in the 
fulfilment of the European fiscal rules, the so-called Stability and Growth Pact (SGP). Ireland and Greece showed public deficits well above the threshold at 3\% of GDP in 2009, respectively, at $13 \%$ and $15 \%$ of GDP, and the Irish deficit was at $32 \%$ of GDP in 2010 after accounting for the nationalization of banks. The surge of public debts and deficits after the GFC would have precipitated Eurozone countries into a new crisis for two reasons: first, it highlighted that the economic governance of the Eurozone was flawed since the very beginning because national fiscal policies shared a heavier burden for stabilization in the absence of a fiscal union to complement the monetary union (Wyplosz 1997); second, fiscal policies which produced high deficits and debts were not effective at stabilizing the economy. Under what was only an assumption-fiscal policy is not effective at stabilizing the economythe cure to the so-called "sovereign debt crisis" was easy to find: fiscal austerity. Large public deficits hence initiated a third phase of radical change in fiscal policy with the implementation of consolidation measures and fiscal austerity.

More than a flaw of economic governance-it could have been overturned by the coordination of fiscal policies under some discretion (Creel and Sterdyniak 1998) the view according to which the European crisis is related to "sovereign debts" reveals a long-lasting reluctance for the use of fiscal policy. This is clearly visible in the economic governance which has settled: a dominant independent central bank that sets the common interest rate and national governments facing fiscal limitations. The central banker is supposed to steer the Eurozone economy into a steady state and is protected from the negative spillovers of supposedly lax fiscal policies.

Where did this view on fiscal policy originate? The answer is quite certainly in the fallacy that fiscal contraction proves expansionary (Giavazzi and Pagano 1990, called it a "tale" but were very influential at using it to be critical of active fiscal policies) ${ }^{1}$ and also in the application of "rational expectations" in general equilibrium macro models. In a world without frictions, like price and wage rigidities, and under "rational expectations", tax and fiscal discretion mainly add noise and biases to the economy. They destabilize rather than stabilize it. The optimal policy is thus characterized by a stable and easily expected policy, hence the fiscal rules.

In a different framework, with frictions and in the presence of demand-driven unemployment, tax and fiscal policies have very different outcomes. ${ }^{2}$ The choice of fiscal policy is therefore a matter of economic conditions, and so is its real effectiveness. It is not a minor paradox that the economist who restored the "fiscal multiplier effect" is the same economist who acted as the IMF chief economist during the so-called sovereign debt crisis. Indeed, O. Blanchard, with R. Perotti, renewed interest in fiscal policy in 2002 with the publication of a paper that concluded that the fiscal multiplier, i.e. the impact of a change in fiscal policy on real output, had been positive and slightly above unity in the US since the early 1950s. This work has been applied to many other countries by many other economists (e.g. Creel et al. 2007, on

\footnotetext{
${ }^{1}$ The expansionary fiscal contraction literature has been much criticized, recently by Guajardo et al. (2014) and Jorda and Taylor (2015).

${ }^{2}$ Or in the behavioural model by Gabaix (2016), with myopia in households' expectations.
} 
French data) and reached the same conclusion: fiscal policy has had positive real effects. The same O. Blanchard published a paper, with D. Leigh, in 2013 in which he acknowledged that "stronger planned fiscal consolidation has been associated with lower growth than expected" because "fiscal multipliers were substantially higher than implicitly assumed". The "implicit" assumption was striking in that it was totally opposite to the results found in the macro literature since the early 2000 s, even before mentioning papers by Creel et al. (2011) and DeLong and Summers (2012), who discussed the non-linear empirical properties of the fiscal multiplier effect relative to the output gap. ${ }^{3}$

Clearly, the academic literature has not had the expected impact: The views of policymakers on fiscal policy have overemphasized the risks of insolvency while under-emphasizing the real effects, in sharp contrast with the literature that had clearly pointed out the risks of fiscal austerity (e.g. Ilzetzki et al. 2013; Brinca et al. 2016). Finally, the idea that under an incomplete monetary union (i.e. without a federal budget) domestic fiscal policies would face the bulk of stabilization requirements while proving ineffective at achieving stabilization was not only contradictory but also wrong. Unfortunately, it spurred the wrong policies. In this respect, the focus on public finances was ill-designed.

\section{The Disastrous View}

Another explanation behind the European imbalances relates to the sudden stop of net capital inflows in the Eurozone periphery, which would have triggered balanceof-payment crises (see e.g. Cesaratto 2013; Baldwin and Giavazzi 2015).

With the advent of the euro in 1999 and free mobility of capital since 1990, crossborder capital flows have increased substantially. Initially, it was perceived as an improvement in macro stability and consistent with the idea that the Eurozone was becoming endogenously optimal. Lagging countries-countries with low investment ratios-accumulated current account deficits that they funded out of increasing credits and capital inflows from leading Eurozone economies. These countries accumulated in return current account surpluses, hence they pursued mercantilist policies. Meanwhile, they found attractive financial opportunities in the least-capitalized economies in the southern and eastern parts of the Eurozone where yields were high due to capital scarcity. High returns were not perceived as risky since, by definition, the exchange-rate risk had vanished. Convergence was therefore expected. However, and finally, a crisis erupted in the peripheral countries. According to the disastrous view, the roots of the crisis had to be found in the malfunctioning of financial markets, i.e. their inability to price risk correctly, which sparked a lack of confidence and outward capital flows, which then provoked a balance-of-payment crisis.

\footnotetext{
${ }^{3}$ The more negative the output gap, the larger the fiscal multiplier.
} 
There are at least two shortcomings of this disastrous view. The first is its "onesize-fits-all" characteristic. It seems to take for granted that all peripheral countries are alike. However, Greece, Portugal, Spain, and Italy did not share the same growth regimes before and after the crisis (see Hein et al. 2016, for a comprehensive comparative analysis). Before the crisis, Greece and Spain could be described as debt-led private-demand boom countries, the former undergoing a boom in private consumption and twin (public and current account) deficits whereas the latter suffered from a housing price bubble. Both countries had high real GDP growth rates, a declining savings ratio and increasing private and public (for Greece) debts. Alternatively, Italy and Portugal could be described as domestic demand-led countries, showing low real growth rates and growing indebtedness but neither a sharp deterioration in their current account balance nor a bubble on the real estate or financial markets. After the crisis, Italy, Portugal, and Spain shifted to an export-led mercantilist growth model, but not Greece. In light of these different characteristics, it is hardly possible that a single explanation for these four countries can emerge. The different sizes of their current account imbalances implied different sensitivities to a sharp reversal of capital flows. Moreover, the balance-of-payment crisis argument neglects the fact that real GDP growth also remained subdued in countries with a current account surplus.

The second shortcoming relates to the timing and structure of the external funding of the peripheral countries: neither characteristic lends much support to the balanceof-payment crisis. Concerning the timing, Fig. 2 shows that foreign private investment in Greece and Portugal increased after the advent of the crisis and decreased only very late. In contrast, the drop was sharp and timely in France. . . although this country did not undergo a so-called balance-of-payment crisis. A timely drop in external funding for Greece is clearly apparent in Fig. 3, however, where "other investments" of the balance of payment are concerned. These "other investments" mostly come from foreign bank credit. Hence the drop looks like a confidence crisis from foreign banks or a crisis of financialization rather than a balance-of-payment crisis per se. Alternatively, it can be viewed as a confidence crisis stemming from the absence of a purchaser of last resort (see e.g. Lavoie 2015), which has contagious effects on the credit supply of private banks.

\section{The Cynical View}

The next explanation behind the surge of macro imbalances in peripheral countries is intrinsically related to the former view as it focuses on the trade imbalances in these countries. In contrast with the disastrous view, however, it does not draw on capital movements but on labor market deficiencies. The cynical view states that peripheral countries ran into the crisis because of a lack of competitiveness (see e.g. Sinn 2014). The adoption of the euro was followed by an increase in nominal wages well above the growth of labor productivity, hence by large increases in unit labor costs (ULC), which deteriorated competitiveness and the trade balance. While ULC decreased in 

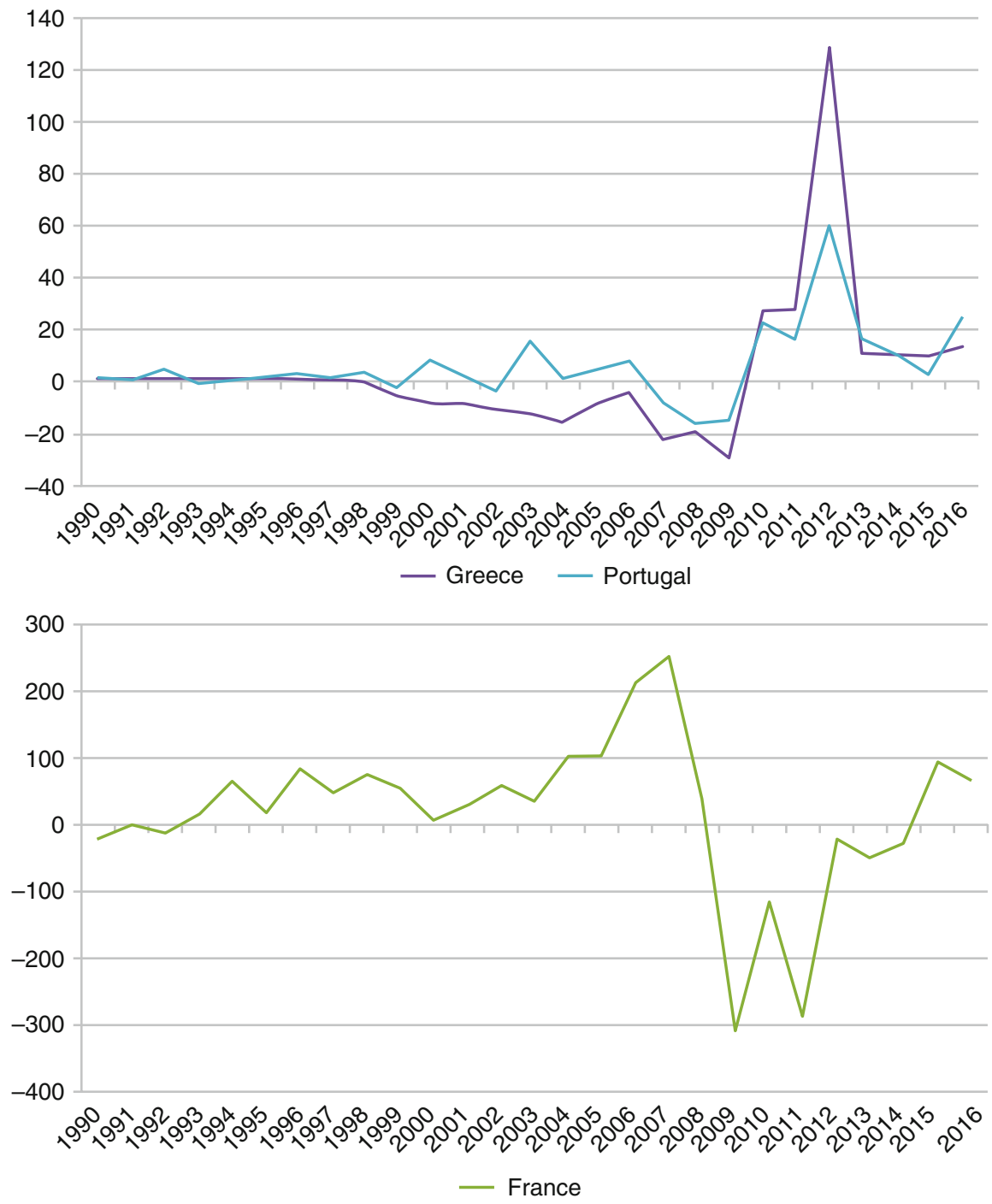

Fig. 2 Net portfolio and foreign direct investments, \$bn. Source: World Bank https://data. worldbank.org/, date of access 20 September 2017

Germany, they increased everywhere else and quite substantially in Ireland, Greece, Italy, Portugal, and Spain. Although it is undeniable that a gap in ULC between Germany, on the one hand, and most other Eurozone countries, on the other hand, occurred after the adoption of the euro, does that mean that the evolution of nominal wages lies at the heart of the crisis in the peripheral countries? We can doubt that for many reasons. 


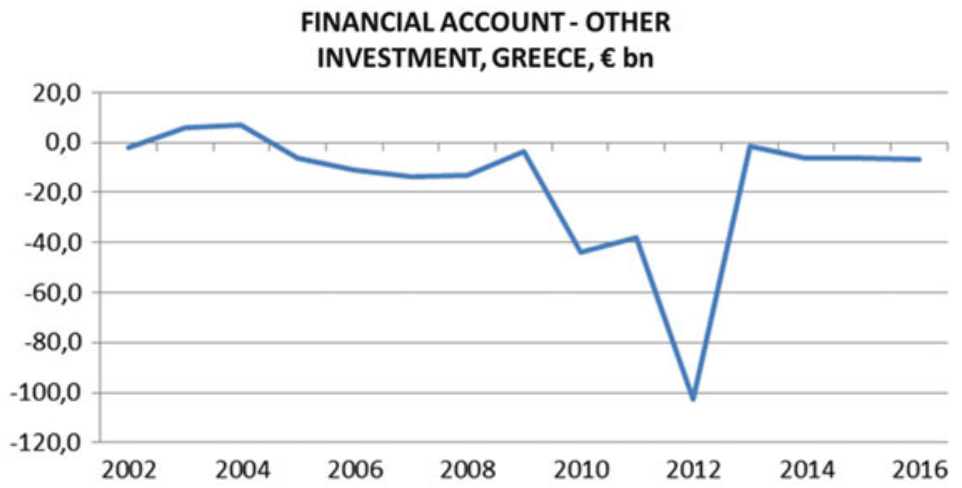

Fig. 3 Financial account, other investment, balance of payment of Greece, €bn. Source: Bank of Greece, https://www.bankofgreece.gr/pages/en/statistics/default.aspx, date of access 20 September 2017

First, trade balance does not depend solely on competitiveness; external and internal demands also matter. Second, nominal wages are not the single determinant of competitiveness. The latter can be divided into two parts: price and non-price competitiveness. While nominal wages have no direct impact on non-price competitiveness, they have an impact on price competitiveness but only jointly with productivity, markups, and labor taxes. Consequently, the influence of nominal wages on price competitiveness, all else being equal, is limited. Third, turning to real, not nominal, ULC gives interesting insights. Since the adoption of the euro, real ULC have been steady in core countries whereas they declined in peripheral countries (Villemot 2017). This is a striking result that proves that wages did not grow excessively in the periphery. On the contrary, part of the value added has shifted from wages to profits. Finally, "competitiveness is not a policy variable" (Gros 2012): in a market economy, supranational institutions and governments do not govern private wages; they can only set or influence public wages. It is clear from the management of the European crisis that the obsession with competitiveness led to policy recommendations to curb nominal wages in order to improve trade balances. The effectiveness of these recommendations is questionable in light of the limited impact of nominal wages. It is even more questionable if only public wages have declined.

Nevertheless, promoters of the cynical view may praise themselves for having fixed the crisis: trade imbalances have receded in the periphery since 2011. Drawing on the former arguments, being sure that these improvements stem from the application of policy recommendations is still an open issue. Turning to the data gives some interesting results. The separation of the respective contributions of exports and imports to the change in the trade balance offers a rough estimate of the impact of competitiveness. Assuming that different countries are highly integrated, hence face similar growth conditions, if the contribution of exports is high, and higher than that of imports, the 


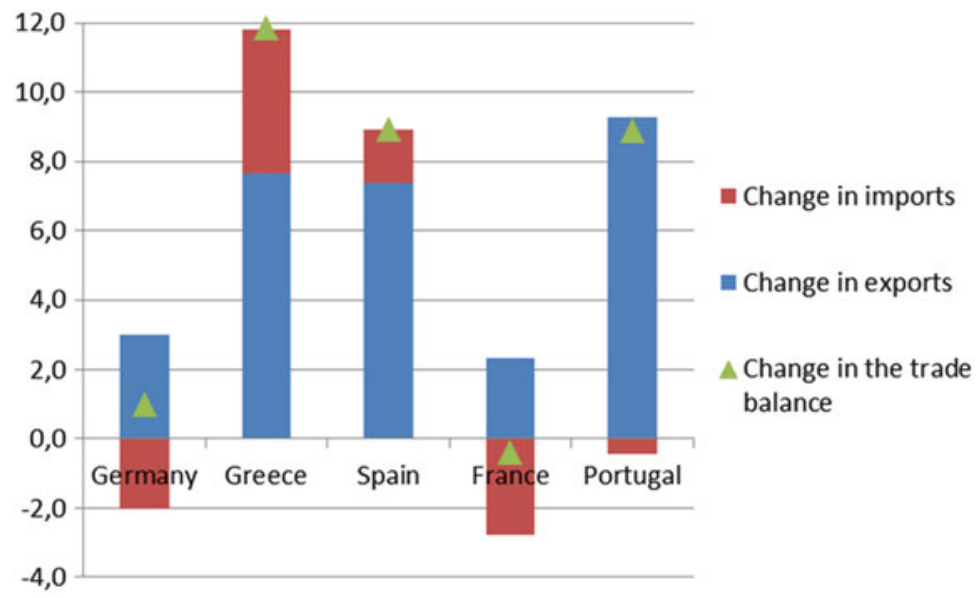

Fig. 4 Change in the trade balance, 2007-2016, in per cent of GDP. Sources: Ameco (https://ec. europa.eu/info/business-economy-euro/indicators-statistics/economic-databases/macro-economicdatabase-ameco/ameco-database_en) and own calculations, date of access 20 September 2017

impact of competitiveness may be strong. Figure 4 shows the contributions to the change in the trade balance for five European countries over a decade. The core countries show quite different patterns: Germany had an improvement in its trade balance due to a higher increase in its exports than imports and France had the complete opposite. The peripheral countries had sharp improvements in their trade balance but also different patterns. All the improvement in Portugal comes from the export side and most of the improvement in Spain comes from the export side whereas only two-thirds of the improvement in Greece comes from the export side while the remaining third comes from the import side. The competitiveness effect seems to have been higher in Portugal than in Spain, and higher in Spain than in Greece.

Now, notwithstanding the roughness of the evaluation-the countries neither face similar growth nor share the same geographical trade structure- the sensitivity towards competitiveness induces some threats that economic prospects pose on future trade balances. The resumption of economic growth in peripheral countries will impinge on imports: In a country like Greece, it may produce a quite substantial deterioration in the trade balance, hence a new headwind on a recovering economy. More importantly, for countries that have gained price competitiveness over the recent years, the prospect of an appreciating euro (notably because of the large current account surplus of the Eurozone vis-à-vis the rest of the world) is definitely unfavorable.

This cynical view, were it true, would thus jeopardize the Eurozone recovery. Remedies to a lasting crisis need to be found outside its boundaries. 


\section{The Comprehensive View}

A comprehensive view of the roots of the European crises can be found in a mix of the former three views. A common drawback of these views is their respective focus on a single determinant and their undervaluation of the impact of the global financial and economic crisis. Against its backdrop, the steep rise in public debts and external debts stemming from large public and current account deficits certainly weakened the peripheral countries more than the core countries. As a matter of fact, the latter countries had either public finances and current accounts in order (e.g. Germany) or limited current account imbalances (e.g. France) before the global crisis. In contrast, other countries had high public deficits and debts before the crisis (e.g. Greece) while some had large current account deficits (e.g. Spain). The emergence of the global financial crisis thus intensified European imbalances, paving the way for a crisis of confidence, a sovereign debt crisis and a competitiveness crisis, with flawed EU governance institutions reluctant to share risks.

In contrast with the three former views, however, the comprehensive view also questions the relevance of policies in the surplus countries. As a matter of fact, the comprehensive narrative involves three interconnected determinants that triggered the European sequel of the global crisis: public finances, current account imbalances, and the output gap, which are not limited to deficits. Indeed, the absence of, for example, a fiscal stimulus in surplus countries may have slowed recovery down domestically but it may also have proved detrimental to deficit countries (Blanchard et al. 2017). It was difficult to reduce the output gap and the current account deficit in the latter countries while they were facing low external demand.

These three interconnected determinants are certainly also essential for dampening the crisis. This view is at the center of Blot et al.'s (2017) and the IMF's (2017) analyses about measuring current account imbalances and how to fix them.

Blot et al. (2017) compute the gap between the structural trade balance (STB) and the trade balance that stabilizes the net international investment position (NIIP) at a desired level expressed as a \% of GDP. ${ }^{4}$ The structural trade balance of a country depends on the output gap of the economy: a negative output gap signals a weak internal demand that diminishes imports. Closing the output gap worsens the trade balance. The structural trade balance also depends on the output gaps of trade partners: if they face a negative output gap, they import less from the country. Closing their output gap then improves the trade balance of the country. Results show that some countries, first and foremost Greece, need to strongly increase their STBs to reach the target. Finland, France, Italy, Portugal, and Spain are also concerned but to a

\footnotetext{
${ }^{4}$ The desired level is given by the threshold, at $-35 \%$ of GDP, of NIIP in the Macro Imbalance Procedure (MIP). The MIP aims to monitor, prevent, and correct the emergence of potentially harmful macroeconomic imbalances that could adversely affect economic stability in a member state. The legal bases of MIP are regulations (EU) 1176/2011 and 1174/2011.
} 
lesser extent. Conversely, Germany and the Netherlands, which already have the highest NIIPs, should reduce their STBs since the current ones imply growing NIIPs.

The IMF (2017) uses the external balance assessment (EBA) model to estimate the relationship between the current account, some fundamental variables (e.g. mediumterm growth potential), and policy variables (e.g. the fiscal stance). Then, the estimated impact of changes in terms of trade and the output gap enables the construction of a cyclically-adjusted measure of the current account balance. Finally, based on desired levels attributed to policy variables, current account norms and current account gaps vis-à-vis the cyclically-adjusted current accounts are calculated. France, Italy, and Spain report weaker gaps than the previous year whereas Germany shows a substantially stronger gap. Moreover, the analysis shows that some countries, e.g. France and Spain, with a negative current account gap (they should improve competitiveness) also have a negative fiscal gap (they should consolidate their budget) while the reverse is true for Germany. Meanwhile, it also shows that the first group of countries, including Italy, has a negative output gap whereas Germany has a positive one.

Both analyses thus point to the symmetry in the current account imbalances between deficit and surplus countries and to the interconnections between fiscal policy, competitiveness, and the output gap. Consequently, symmetry in the management of imbalances through policy coordination would help dampen them. Blot et al. (2017) show that the Eurozone governance is plagued with internal inconsistencies. First, fiscal sustainability requirements mainly rest on fiscal consolidation though the latter produces falls in output, which may in turn reduce trade balances to below (structural) targets. Second, reducing macroeconomic imbalances can be achieved through an improvement in price competitiveness although low inflation makes it harder to curb debt via the Fisherian effect. ${ }^{5}$ Blot et al. argue for cooperation between deficit and surplus countries to stabilize the economy (and reach a zero output gap), reduce imbalances symmetrically, and achieve the targets embedded in the European fiscal rules. They show that non-cooperative solutions are inconsistent with official Eurozone long-term policy targets. Under an asymmetric management of imbalances - only countries with a public or a current account deficit implement policies to curb them while surplus countries neither use fiscal space nor implement reflation policies-simulations with the iAGS model ${ }^{6}$ show that public debts in surplus countries are substantially below $60 \%$ of GDP while the Eurozone inflation rate is well below the $2 \%$ target at a 20 -year horizon. In contrast, simulations of cooperative solutions, i.e. symmetric fiscal and competitiveness adjustments across deficit and surplus countries, are consistent with official long-term policy targets, including the Fiscal Compact. ${ }^{7}$

\footnotetext{
${ }^{5}$ When debt is issued at a fixed interest rate, higher inflation reduces real interest payments and the real value of debt.

${ }^{6}$ See Blot et al. (2014) for a presentation.

${ }^{7}$ Eurozone countries achieve on average a cyclically-adjusted deficit of $0.5 \%$ of GDP.
} 


\section{A Conclusion About Recent Reforms and Proposals}

The story of European macroeconomic imbalances has had many facets that a highly-focused analysis fails to report. In this respect, a comprehensive view that relates the different analyses certainly fits the history of facts and events better.

In light of this comprehensive view, it is possible to discuss the different recent reforms and proposals dealing with future Eurozone economic governance. Here, I focus on two reforms: the Eurozone fiscal stance and the creation of domestic productivity boards; and three proposals: better coordination of economic policies, better risk management in the Eurozone and the adoption of a Eurozone budget.

Since 2016, the European Commission has been computing an aggregate annual fiscal stance for the Eurozone. This reform stems from the adoption of the 2-Pack and was endorsed by the Council in mid-2016. It relates economic stabilization to sustainability issues. Stabilization and sustainability requirements are computed per country, transformed into domestic fiscal stances, and finally aggregated into a Eurozone fiscal stance. Acknowledging the trade-off between output stabilization and public finance sustainability is welcome: Had this trade-off been introduced earlier, fiscal austerity would not have been frontloaded. The real costs stemming from this strategy would have been limited.

The Council recommended the establishment of national productivity boards in September 2016. They analyze developments and policies that can affect productivity and competitiveness at the domestic level, provide independent analyses, and should reinforce policy dialogue. Nevertheless, as they stand, national productivity boards will not ease the symmetric adjustment of prices in the Eurozone because in all likelihood a one-size-fits-all policy will be implemented. Drawing on some kind of "common wisdom" that so-called structural reforms are conducive to higher productivity, all national productivity boards may finally end up promoting the same policies. If they do, the adoption of a mercantilist stand in all countries alike will increase the current account surplus of the Eurozone vis-à-vis the rest of the world. This will make the Eurozone more vulnerable to external shocks and lead to the appreciation of the euro.

In light of the comprehensive view, separate reforms dedicated either to budget issues or to structural divergences will not help achieve the much-desired two-tier coordination long advocated in the iAGS reports (e.g. OFCE-ECLM-IMK-AK 2016): fiscal coordination with backloading policies and coordination on symmetric structural reforms. Fiscal coordination should aim to use the flexibility of the SGP to minimize the social cost of fiscal consolidation. Symmetric structural reforms, via more or less generous reforms depending on the sign and size of current account imbalances, should help stabilize divergence across the member states and limit the suboptimality of the euro. Despite its Pareto-improving property, ${ }^{8}$ this path of reform is absent from the political agenda.

\footnotetext{
${ }^{8}$ The two-tier coordination can be viewed as a Pareto-improving equilibrium. As a matter of fact, the less cooperation on one-tier, the more stimulus required on the other to counterbalance the social cost and/or the lack of inflation, and the higher the spillovers on partner countries.
} 
Recently, two proposals have emerged in the political agenda. The first path of reform, embodied by former German minister W. Schäuble in his testimony to the Council, is based on two principles. The first requires the enforcement of rules. To achieve this, one needs to simplify the system of rules and focus on the nominal deficit rule and on the rule of return of the public debt to GDP ratio to its $60 \%$ threshold. Moreover, the application of rules should be monitored by the European Stability Mechanism without going through a political process in the Council. By doing so, the rules would be applied more rigorously. The second principle relates to financial risks that threaten cohesion between member states. Given the ECB's large purchases of public debts and the zero risk assigned to them by banks, in line with prudential regulation, the risk of holding an Italian public debt, for example, is artificially made similar to that of holding a German debt. The perverse effect underlying this (possible) undervaluation of risk is to encourage postponing public debt reduction. To bring this situation to an end, market discipline is invoked: the government whose default risk is perceived to be higher should suffer an increase in its risk premium. This would encourage governments to actually reduce their debts.

This path of reform has at least two imperfections. The first is to see a state emerge as a reference for the market. This country will issue by default the only safe asset of the Eurozone. This will increase the divergence of credit costs within the zone, with the referring state borrowing at a lower interest rate than the others. Resorting to market discipline also imposes a strong dependence of states and banks on financial volatility. Ten years after the beginning of a crisis that saw markets unable to properly assess risks, this is an amazing argument.

The second path of reform focuses on the management of economic crises. This management would involve political coordination in sharp contrast with market discipline. The recent situation has shown that the Eurozone does not have an automatic mechanism to boost the economy after a crisis. The French president, in September 2017 at the Sorbonne, defended the adoption of a Eurozone budget to provide investment, emergency financial assistance, and crisis absorption capacity, to be placed under the responsibility of a minister of economy and finance. Other proposals, such as that of the Italian government, advocate that the Eurozone's ministry of economy and finance provide European public goods; for example, transnational public investments or spending on ecological transition. While this path of reform gives some substance to a better management of the interactions between fiscal policy and the output gap, it is silent on current account imbalances.

On 6 December 2017, the Commission set out its proposals of reform with a balanced focus on market discipline and budget integration. The Commission requires the integration of the fiscal rule on the cyclically adjusted deficit (stemming from the Fiscal Compact of 2012) into EU legal framework. This initiative would unfetter the Commission from the intergovernmental dimension of the Fiscal Compact and permit it to resume control over all the budgetary rules. It also shows its attachment to the rules and their stricter application, although it does not demonstrate that these rules have been effective so far. The Commission is also proposing the transformation of the ESM into a European Monetary Fund (EMF), no doubt also to 
avoid an intergovernmental mechanism-the ESM-which reduces its power of initiative and control. The EMF would make adopting a preventive component of budget crises possible.

The Commission proposes the adoption of a stabilization fiscal capacity within the framework of the European budget. The latter would thus share a new function, macroeconomic stability, with the current ones: sustainable growth, competitiveness, cohesion and security. This fiscal capacity would involve a support for public investment in the event of a crisis.

This proposal raises two remarks. On the one hand, in its current form, the EU budget is balanced and therefore irreconcilable with macroeconomic stabilization (which it was not responsible for until then). To be effective, fiscal capacity should be associated with a debt capacity, which has not been mentioned so far. On the other hand, the size of the EU budget is limited. If this limit persists, and given that the UK contribution will vanish after Brexit, a new budget function will question the spending allocation: which ones will decrease to give room to maneuver in the new budgetary capacity?

What might be the implications of these reform proposals on the development of the Eurozone and the EU? In light of the recent contribution by Benigno and Fornaro (2018), the interactions between economic fluctuations, long-run growth, and stabilization policies require a common theoretical framework to offer guidance to policymakers. Clearly, a Keynesian framework, with subdued aggregate demand and unemployment, associated with subdued investment in innovations, can offer this type of guidance. In this framework, innovations can foster productivity growth, hence they can sustain aggregate demand. Moreover, high demand can generate investment, hence higher productivity growth. Consequently, supply-side and demand-side are complementary to enhance a sustainable growth environment where fluctuations are dampened and long-run growth is stimulated.

The current agenda of reforms in the Eurozone ${ }^{9}$ may have a limited impact in this respect, for at least four reasons. First, it is not comprehensive enough. Steps to manage macro imbalances symmetrically are absent from mainstream reform agendas. Second, the outcome of these projects is not for tomorrow as the horizon to reach an agreement on the various aspects of reforms (Eurozone budget, EMF, domestic fiscal rules) could extend to 2025. Unfortunately for the Eurozone, the status quo could last and macro imbalances and economic fluctuations could remain. This may lead policymakers to continue keeping an eye on the short term rather than on the long term. Third, the margins for maneuver embedded in a Eurozone budget (if it were adopted) would remain limited and ill-designed for the required sharp and positive public impetus for investment that would extract the Eurozone from a stagnation trap à la Benigno and Fornaro. Fourth, while the EU has enriched the

\footnotetext{
${ }^{9}$ I do not have sufficient space to develop the position of the 14 Franco-German economists (see Bénassy-Quéré et al. 2018) who focus on the financial and fiscal stability of the Eurozone. They borrow from (or inspire) both paths of reforms that I referred to previously. Their long-term view of the Eurozone is limited to the resilience of the area, i.e. its ability to cope with future macroeconomic and financial shocks.
} 
set of convergence indicators to social ones with the adoption of the European Pillar of Social Rights, there remains a contradiction between the growing number of EU objectives in the European Semester and the constant number of tools and financial means to fulfil them. The achievement of a more equal Eurozone requires more than the multiplicity of "productivity boards" without clear cooperation tools and a vision of structural reforms that continues to aim for flexibility and competition, even though both have already reached high levels in Europe. To promote growth that cares for the future, the EU should turn away from the recipes of the past (an accounting approach of fiscal policy and market-oriented structural reforms), which have not been helpful for fixing the European crisis. In contrast, EU governments should invest in the future and incentivize innovations via tax and fiscal policies.

\section{References}

Baldwin, R., \& Giavazzi, F. (2015, September 7), Towards a consensus on the causes of the EZ crisis. Voxeu.org, https://voxeu.org/article/towards-consensus-causes-ez-crisis

Bénassy-Quéré, A. et al. (2018). Reconciling risk sharing with market discipline: A constructive approach to euro area reform. CEPR Policy Insight, 91.

Benigno, G., \& Fornaro, L. (2018). Stagnation traps. Review of Economic Studies, 85(3), $1425-1470$.

Blanchard, O., \& Leigh, D. (2013). Growth forecast errors and fiscal multipliers. American Economic Review, 103(3), 117-120.

Blanchard, O., \& Perotti, R. (2002). An empirical characterization of the dynamic effects of changes in government spending and taxes on output. Quarterly Journal of Economics, 117(4), $1329-1368$.

Blanchard, O., Erceg, C. J., \& Lindé, J. (2017). Jump-starting the Eurozone recovery: Would a rise in core fiscal spending help the periphery. In M. Eichenbaum \& J. A. Parker (Eds.), NBER macroeconomics annual 2016 (Vol. 31, pp. 103-182).

Blot, C., Cochard, M., Creel, J., Ducoudré, B., Schweisguth, D., \& Timbeau, X. (2014). Fiscal consolidation, public debt and output dynamics in the Eurozone: Lessons from a simple model with time-varying fiscal multipliers. Revue d'économie politique, 124(6), 953-989.

Blot, C., Creel, J., Ducoudré, B., Timbeau, X., \& Villemot, S. (2017). Dealing with external imbalances and public debt objectives in the Eurozone: A dilemma? Presented at Workshop "External imbalances: causes, consequences and rebalancing", October 14, University of Lille1, http://ermees.fr/wp-content/uploads/2017/02/21_anuscript_Blot.pdf

Brinca, P., Holter, H. A., Krusell, P., \& Malafry, L. (2016). Fiscal multipliers in the 21st century. Journal of Monetary Economics, 77, 53-69.

Cesaratto, S. (2013). The implications of TARGET2 in the European balance of payments crisis and beyond. European Journal of Economics and Economic Policy: Intervention, 10(3), 359-382.

Creel, J., \& Sterdyniak, H. (1998). Du bon usage des politiques monétaire et budgétaire en Europe. Revue d'économie financière, 45, 167-196.

Creel, J., Monperrus-Veroni, P., \& Saraceno, F. (2007). Politique budgétaire discrétionnaire en France. Les effets à court et à long terme. Revue économique, 58(5), 1035-1053.

Creel, J., Heyer, É., \& Plane, M. (2011). Petit précis de politique budgétaire par tous les temps. Les multiplicateurs budgétaires au cours du cycle. Revue de l'OFCE, $0(1), 61-88$.

DeLong, J. B., \& Summers, L. H. (2012). Fiscal policy in a depressed economy. Brookings Papers on Economic Activity, 43(1), 233-297. 
Gabaix, X. (2016, December). A behavioral new Keynesian model (NBER working paper no. 22954).

Giavazzi, F., \& Pagano, M. (1990). Can severe fiscal contractions be expansionary? Tales of two small European countries. In O. Blanchard \& S. Fischer (Eds.), NBER macroeconomics annual (pp. 75-111). Cambridge, MA: MIT Press.

Gros, D. (2012, April). Macroeconomic imbalances in the Eurozone: Symptom or cause of the crisis? CEPS Policy Brief, 266.

Guajardo, J., Leigh, D., \& Pescatori, A. (2014). Expansionary austerity? International evidence. Journal of the European Economic Association, 12(4), 949-968.

Hein, E., Detzer, D., \& Dodig, N. (Eds.). (2016). Financialisation and the financial and economic crises. Cheltenham: Edward Elgar.

Ilzetzki, E., Mendoza, E. G., \& Vegh, C. A. (2013). How big (small?) are fiscal multipliers? Journal of Monetary Economics, 60(2), 239-254.

IMF. (2017, July). 2017 external sector report. IMF Policy Paper.

Jorda, O., \& Taylor, A. M. (2015). The time for austerity: Estimating the average treatment effect of fiscal policy. Economic Journal, 126(590), 219-255.

Lane, P. R. (2012). The European sovereign debt crisis. Journal of Economic Perspectives, 26(3), $49-67$.

Lavoie, M. (2015). The Eurozone crisis: A balance-of-payments problem or a crisis due to a flawed monetary design? A reply to Sergio Cesaratto. International Journal of Political Economy, 44(2), 157-160.

OFCE-ECLM-IMK-AK. (2016, November). The elusive recovery. iAGS 2017, independent Annual Growth Survey report.

Sinn, H.-W. (2014). Austerity, growth and inflation: Remarks on the Eurozone's unresolved competitiveness problem. World Economics, 37(1), 1-13.

Villemot, S. (2017). Les déséquilibres des balances courantes dans la zone Euro: comment les résorber?, in OFCE, L'économie Européenne 2017, Repères, Paris: La Découverte.

Wyplosz, C. (1997). EMU: Why and how it might happen. Journal of Economic Perspectives, 11(4), 3-22.

Open Access This chapter is licensed under the terms of the Creative Commons Attribution 4.0 International License (http://creativecommons.org/licenses/by/4.0/), which permits use, sharing, adaptation, distribution and reproduction in any medium or format, as long as you give appropriate credit to the original author(s) and the source, provide a link to the Creative Commons licence and indicate if changes were made.

The images or other third party material in this chapter are included in the chapter's Creative Commons licence, unless indicated otherwise in a credit line to the material. If material is not included in the chapter's Creative Commons licence and your intended use is not permitted by statutory regulation or exceeds the permitted use, you will need to obtain permission directly from the copyright holder.

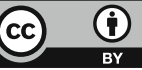




\title{
Unable to Stop Inequality from Rising: Evidence from Romania
}

\author{
Paul Dobrescu and Flavia Durach
}

\section{Introduction}

In today's world, there are no fundamental issues, from development to social mobility, from migration to social inclusion, separate from the process of growing inequality. The process is not stagnant; the economic crisis in 2008-2009 deepened inequalities instead of mitigating them. In recent years, inequality surfaced in the shape of social unrest, protest movements and unpredictable voting behaviour. In this respect, the year 2016 was a turning point. Brexit, Trump's election as president, the ascent of populism - all these events were the indirect result of public discontent, exacerbated by inequality. Economic inequality needs to be correlated with its social consequences, thus pushing the issue onto the political agenda. In this vein, the editors of the volume After Piketty, The Agenda for Economics and Inequality note that when Piketty's ground-breaking work was published in 2014, its predictions were questioned: "maybe, but also maybe not" (DeLong et al. 2017, p. 2). Three years have passed, and during this time, facts piled up to support the French author's view. "And so, Piketty's analytical political economic case looks to us to have been greatly strengthened by Trump's presidential election victory" (DeLong et al. 2017, p. 2). The conclusion is unequivocal: "If Piketty s book was distastefully radical before, now it looks vitally necessary" (DeLong et al. 2017, p. 4).

The World Economic Forum 2018, in Davos, discussed international stability as a recurrent theme. When a forum of such magnitude expresses concerns regarding the

This chapter has been prepared with financial support granted in the project "State of the Nation. Designing an innovative instrument for evidence-based policy-making" (SIPOCA 11, MySMIS 118305), which is co-financed by the European Social Fund through the Operational Programme Administrative Capacity 2014-2020.

P. Dobrescu $(\bowtie) \cdot$ F. Durach $(\varangle)$

National University of Political Studies and Public Administration, Bucharest, Romania e-mail: paul.dobrescu@comunicare.ro; flavia.durach@comunicare.ro 
stability of today's world, it implies that great threats are emerging. What are those threats, to be more precise? Branco Milanovic (2016) provides an explanation. The author shows that global inequality between nations has a similar evolution to the inequality within nations.

By relating to the aforementioned ways of understanding inequality, this chapter investigates the different faces of inequality within Romania, with an emphasis on regional disparities. Furthermore, we aim to pinpoint the country's ranking in its geographic region (Central and Eastern Europe) as reflected by some key indicators of development. A secondary focus of our study will be on the Romanian citizens' perceptions of inequality, using data from a representative public opinion survey conducted in the project The State of the nation. The development of an innovative instrument for grounding the development of public policies in Romania.

\section{Towards a Second "Gilded Age": Trends in National and Global Inequality}

Thomas Piketty's highly acclaimed work Capital in the 21st Century (2014) provides a historical analysis of the evolution of income and wealth dating back to the eighteenth century. His empirical findings are troubling: The turn of the century witnessed a return to the high levels of inequality experienced in darker, earlier times in human history. The author shows that cyclicity is an intrinsic feature of inequality, defined as the gap between capital's share and labour's share of the national income. More precisely, capital's share ranged between $35-40 \%$ between the late 18th through the 19th centuries, falling to $25-30 \%$ in the mid-twentieth century and increasing again to $25-30 \%$ in the late twentieth and early twenty-first centuries (Piketty 2014, p. 200).

Inequality tends to increase or decrease according to the variations of the economy. Capital in the twenty-first Century postulates that when the return on capital is greater than national growth, it tends to accumulate faster, make inherited wealth more relevant, and exacerbate inequalities. As we are currently witnessing a period of reduced growth (in economic and demographic terms), capital gains significant momentum to the detriment of labour (Piketty 2014, p. 166). In other words, we are living in an age when capital is making its comeback. We are heading to a second "gilded age", dominated by wealth (especially inherited wealth) to the detriment of income, an age in which the owners of capital will have the power to shape the course of economy and politics while skyrocketing differences in income will lead to a growing divergence between social groups.

Inequality within nations (described above) is only one side of the coin; to flip the coin means looking at inequalities between countries. In this vein, Milanovic (2016, p. 20) argues that the winners of globalisation are the "global middle class located mostly in China and other countries from resurgent Asia, whereas the main losers are the lower middle classes of the rich world". To justify his bold statement, the author 
measures the relative gain in real household per capita income between 1988 and 2008 at different points of the global income distribution, noting that real income gains were greatest among people around the 50th percentile of the global income distribution (most of them coming from emerging Asian economies), and among the richest $1 \%$. The lowest gains came for the 80th percentile globally, meaning the lower middle class of the rich world (Milanovic 2016, p. 11). Inequality within countries is likely to intensify:

The great middle-class squeeze, driven by the forces of automation and globalization, is not at an end. This squeeze will in turn further polarize western societies into two groups: a very successful and rich class at the top, and a much larger group of people whose jobs will entail servicing the rich class in occupations where human labour cannot be replaced by robots. (Milanovic 2016, pp. 214-215)

\section{The Economic and Social Consequences of Inequality}

There is broad debate in the literature whether inequality is good or bad. That depends on what we have in mind. There is a normal, positive inequality, which stimulates growth by enforcing a merits-based hierarchy of success. However, in this chapter we focus on negative, destabilizing or malign levels of inequality. The comments of IMF director Christine Lagarde are a perfect illustration of our point:

Our research shows that, if you lift the income share of the poor and middle class by $1 \%$ point, then GDP growth increases by as much as $0.38 \%$ points in a country over five years. By contrast, if you lift the income share of the rich by $1 \%$ point, then GDP growth decreases by $0.08 \%$ points. One possible explanation is that the rich spend a lower fraction of their incomes, which could reduce aggregate demand and undermine growth. In other words, our findings suggest that - contrary to conventional wisdom - the benefits of higher income are trickling up, not down. This, of course, shows that the poor and the middle class are the main engines of growth. Unfortunately, these engines have been stalling. (Lagarde 2015)

Inequality has broad social consequences, resulting in a higher or lower public tolerance of this phenomenon. In social contexts where citizens have a real possibility to advance through personal merit and hard work, tolerance towards inequality is higher, whereas in societies or social groups where opportunities for social mobility are fewer, the tolerance is significantly lower.

Scholars link inequality to intergenerational mobility and social mobility (Ermisch et al. 2012; Krueger 2012; Jerrim and Macmillan 2015). Furthermore, inequality threatens equal opportunities, and increases the importance of inherited fortune (Piketty 2014). According to the Great Gatsby Curve (Krueger 2012), unequal states have less economic mobility than their counterparts. In such states, the poorest tend to limit their life aspirations since their efforts prove to be in vein in the absence of inherited wealth (Dalton et al. 2015).

The figures are mirrored by the public perception of inequality. The US, for instance, where inequality is on the rise, is witnessing, for the first time in history, the demise of the American dream. The recent work of Graham (2017) questioned Americans on their perceptions of the future and on how hard work could help them 
advance on the social ladder. Results suggest that Americans are no longer tolerant towards inequality. This striking result is the consequence of a lack of faith in the American dream-achieving success through a combination of hard work, vision and good luck. In 2016, only 38\% of Americans thought their children would be better off than they are. This change is especially valid for poor citizens, whereas the rich continue to believe that hard work and education will allow them to prosper more than previous generations.

We are experiencing a time when excessive inequality surfaces in the shape of social turmoil. Few realize that people's confidence in the concept of upward mobility, based on hard work and high performance of talent (going "from rags to riches", the quintessence of the American dream) fuels capitalism. Excessive inequality limits upward mobility while consolidating the dominance of the select few, based on inherited wealth instead of merit. Inequality makes social structures more rigid and directly affects the legitimacy of the establishment. "That's the problem with increased inequality-it diminishes upward mobility. It makes the top and bottom rungs of the ladder "stickier"- harder to move up and harder to lose your place at the top" (Obama 2016).

During the International Conference Centesimus annus pro Pontifice Foundation, Pope Francis stated that "an economy of exclusion and inequality" produces an evergrowing number of "the disenfranchised and those discarded as unproductive and useless". By emphasizing the need to change this reality, the pontiff called for "new models of economic progress" which are "more clearly directed to the universal common good, inclusion and integral development, the creation of labour and investment in human resources" (Pope Francis 2016).

\section{Inequality in Romania}

The second half of this chapter is dedicated to analyzing inequality in Romania and its impact on the country's development. By means of secondary data analysis, we use institutional sources (such as Eurostat, the National Institute of Statistics in Romania, and the National Bank) to assess the level of economic inequality from multiple perspectives and identify the main drivers of inequality. Lastly, we discuss the consequences of severe inequality on the inclusive, long-term development of Romania. Following T. Piketty's approach, we discuss inequality, among others, through the ratio between the capital share and the labor share of the national income. We explore the consequences at a societal level by analyzing the distribution and redistribution processes. Lastly, we address soft issues related to the public perception of inequality.

The period of analysis is between 1990 (following the fall of the communist regime in Romania) and 2017 (depending on the data availability at the time of writing this chapter). Where feasible and relevant for our argument, we favor a comparative approach to other countries in Central and Eastern Europe as well as to the EU average. We define Romania's peer group as consisting of Hungary, Bulgaria 
and Poland based on geographical proximity (Hungary, Bulgaria), a similar level of development (Bulgaria) and similarity in size (Poland).

The analysis of inequality in Romania in the last three decades must take into consideration the country's transition to a democracy and the market economy, a transition challenged by the global competition and circulation of foreign capital, as core features of globalization. The scale of Romania's transformation led not only to positive change but also to contradictions and tension. Rising inequality distinguishes itself as a serious issue given the complexity of its causes and the magnitude of its consequences.

Before debating the distribution of income, we must discuss economic performance in terms of GDP and national income. What matters here is the size of the "pie"-is the shared wealth large enough to satisfy both capital owners and workers? We will depict Romania's evolution in terms of GDP and national income, followed by a comparison with other countries in its peer group. From this point of view, the process of distribution and redistribution of the newly created value in an economy has strategic importance.

Data show that Romania's GDP had many fluctuations in the last 30 years. The country experienced two sharp economic declines in this recent history: the first after the fall of the communist regime in 1989, when the economy contracted by $40 \%$ in only 3 years (from 42.105 billion US dollars in 1989 to 25.122 billion US dollars in 1992). It took almost a decade to reach the GDP from 1989 again. The second crash took place after the 2008-2009 crisis, when the GDP decreased by $19 \%$ in just 1 year, from 208.192 billion US\$ in 2008 to 167.423 billion US\$. Once again, recovery was slow and hard: it took 6 years to reach a similar GDP level (US $\$ 199.493$ billion in 2014), only to experience another steep decrease the following year (World Bank Database, accessed 2017, GDP in current US\$). The lengthy recovery periods suggest a lack of robustness of Romania's economy and a low resilience to economic shocks.

Many things can be said about Romania's transition to a market economy; what is of the greatest importance is that during those years, everybody talked about reform and modernization while the country's economy plummeted. While development cannot be reduced to economic growth, development cannot happen in its absence either. Thirty years later, one can see that the mantra of reform and modernization failed to ensure sustainable and inclusive progress as the gaps between Romania and other countries in Western, Central and Eastern Europe widened.

When turning to Eurostat data, we see that in 1989, Romania's GDP was US $\$ 38.995$ billion and Poland's was US\$65.978 billion (World Bank Database, GDP in current US\$). Hence, Romania's GDP was approximately two-thirds of Poland's GDP while having half its population. Later, in 2000, Romania's GDP was approximately the same as in 1990 (US $\$ 37.439$ billion) while the Polish one had grown 2.6 times (US $\$ 171.886$ billion). During that decade, Romania had failed to grow as an economic power while Poland had amplified its economy 2.6 times. After the year 2000, Poland managed to sustain its growth. Between 2000 and 2016, its GDP rose 2.7 times, reaching the impressive amount of US $\$ 471.364$ billion (7.1 times greater than in 1990). During the same interval of 1990-2016, Romania's GDP rose only 
4.8 times. Furthermore, Poland managed to strive despite the economic crisis, thus proving its capacity for reform instead of de-industrialization (in the same vein, also see Zamfir 2017).

A decade of EU membership has failed to close the gaps between Romania and other countries. According to the latest Eurostat data, Romania's real GDP/capita in 2016 was EUR 7700 compared to EUR 27,000 (EU28 average). Romania's GDP/capita is significantly lower than its peers in CEE: 11,200 EU in Poland and 11,300 in Hungary. Bulgaria is the only EU member state with a lower GDP/capita than Romania (Eurostat, tsdec100).

The GDP is not the only indicator of a nation's economic prosperity. One must analyze the national income as well, meaning the sum of all income available to the residents of a given country in a given year regardless of the legal classification of that income (Piketty 2014). The national income differs from the GDP in two ways. Firstly, to calculate the national income, the depreciation of capital must be subtracted from the GDP. Secondly, one must add net income received from abroad and subtract net income paid to foreigners, depending on each country's situation (Piketty 2014). In Romania's case, the net national income is significantly lower than its GDP. In 2014, Romania had a GDP of EUR 150,357 million and a net national income of EUR 121,452 million, a modest improvement since EU accession (when the net national income was EUR 100,925 million) (Eurostat, tsdec230 and nama_10_gdp).

As suggested by the data above, Romania has a modest national wealth to distribute between capital and labor. Since this chapter is devoted to the topic of inequality and ways to reduce it, we must emphasize Romania's handicap of having a smaller "pie" to share than other countries in the region. This disadvantage must be taken into consideration and, where possible, corrected through distribution between capital and labor. Is the distribution process conceived and implemented in order to correct, or at least ameliorate this economic handicap of Romania? We would say the contrary, as Table 1 shows.

In 2016, the labor share was as low as $41.6 \%$. In the last 17 years, the labor share in Romania was the greatest in 2001 (52.5\%) and the lowest in 39.9\% (in 2013). That means that the main cost of the economic crisis was paid by labor. The labor-capital share ratio lays the conditions for the perfect storm. For example, in 2016, 38.8\% of Romania's population is at risk of poverty (Eurostat, t2020_50). Bulgaria is the only EU member to have a larger share of its population at risk of social exclusion. The EU average is of $23.5 \%$. We would also like to draw attention to the fact that in 2016, the richest 20\% of Romanian citizens had an income 7.2 times greater than the poorest 20\%; a ratio higher than in other CEE countries such as Poland (4.8) and Hungary (4.3) (Eurostat, ilc_di11).

The third category of factors influencing social inequality is related to economic redistribution (e.g. government expenditure for education, health, public infrastructure, etc.). Given the economic context in Romania (low GDP, unequal distribution between capital and labor), public investments in the aforementioned areas can only be deficient. In the logic of our argument, let us imagine a hypothetical situation in which the wages of two individuals or groups are sensibly different. In the public 
Table 1 Labor share in the net national income

\begin{tabular}{l|l|l|l|l|l}
\hline \multicolumn{2}{l}{ Labor share in the national income } \\
\hline & USA (\%) & Germany (\%) & France $(\%)$ & UK $(\%)$ & Romania (\%) \\
\hline 2000 & 66 & 64 & 58 & 60 & 50 \\
\hline 2007 & 64 & 56 & 59 & 60 & 46 \\
\hline 2008 & 65 & 58 & 60 & 60 & 48 \\
\hline 2009 & 64 & 60 & 62 & 62 & 47 \\
\hline 2010 & 63 & 59 & 62 & 60 & 44 \\
\hline 2011 & 62 & 58 & 61 & 58 & 41 \\
\hline 2012 & 61 & 60 & 62 & 59 & 41 \\
\hline 2014 & 61 & 60 & 63 & 60 & 40 \\
\hline 2016 & 63.8 & 60.1 & 62.5 & 59.7 & 39.7 \\
\hline
\end{tabular}

Source: Georgescu, F., First Deputy Governor, National Bank of Romania (2017). Retrieved from: http://www.bnr.ro/Prezentari-si-interviuri\%2D\%2D1332.aspx?fld_issue_year=2017, accessed November 11th, 2017

system of education, the state delivers a free adequate education for everyone, irrespective of income. From this perspective, the education system not only channels the young generation's full potential but also enforces equal opportunities for all members of society. A similar logic of state intervention can be applied to infrastructure and health services as well.

Instead of reducing inequality and stimulating inclusive development, the current low levels of government expenditure aggravate gaps and threaten Romania's development. As far as public spending is concerned, Romania is last in its region as well as in the EU (Fig. 1).

Government expenditure includes the current spending and investment by central government and local authorities, directed towards providing social goods and services and serving the needs of the community. In 2016, total government expenditure in Romania rose to $34.7 \%$ of the GDP whereas the EU average was $46.6 \%$ (12 pp. higher). Romania's peer group performed better, with Hungary leading the way $(47.5 \%)$, followed by Poland $(41.3 \%)$ and Bulgaria $(35.5 \%)$.

Data are particularly worrying since the state is the main provider of basic services and investments in vital sectors such as health, education and infrastructure. Via redistribution, the state has the ability to tackle inequality and foster development. The public health and education systems, which should guarantee high-quality services for all, suffer equally from insufficient funding. In Romania, the health sector receives the least financial resources compared to the EU average and the peer group. In 2015, the Romanian government allocated $4.2 \%$ to health compared to 7.2\% the EU average, 5.5\% in Bulgaria, 5.3\% in Hungary, and 4.7\% in Poland. As far as education is concerned, Romanian government spending is significantly lower $(3.1 \%)$ than the EU average (4.9\%). It is worth mentioning that in the peer group, Poland and Hungary make education a top national priority by investing more than the EU average in this area (5.2\% in both cases). 


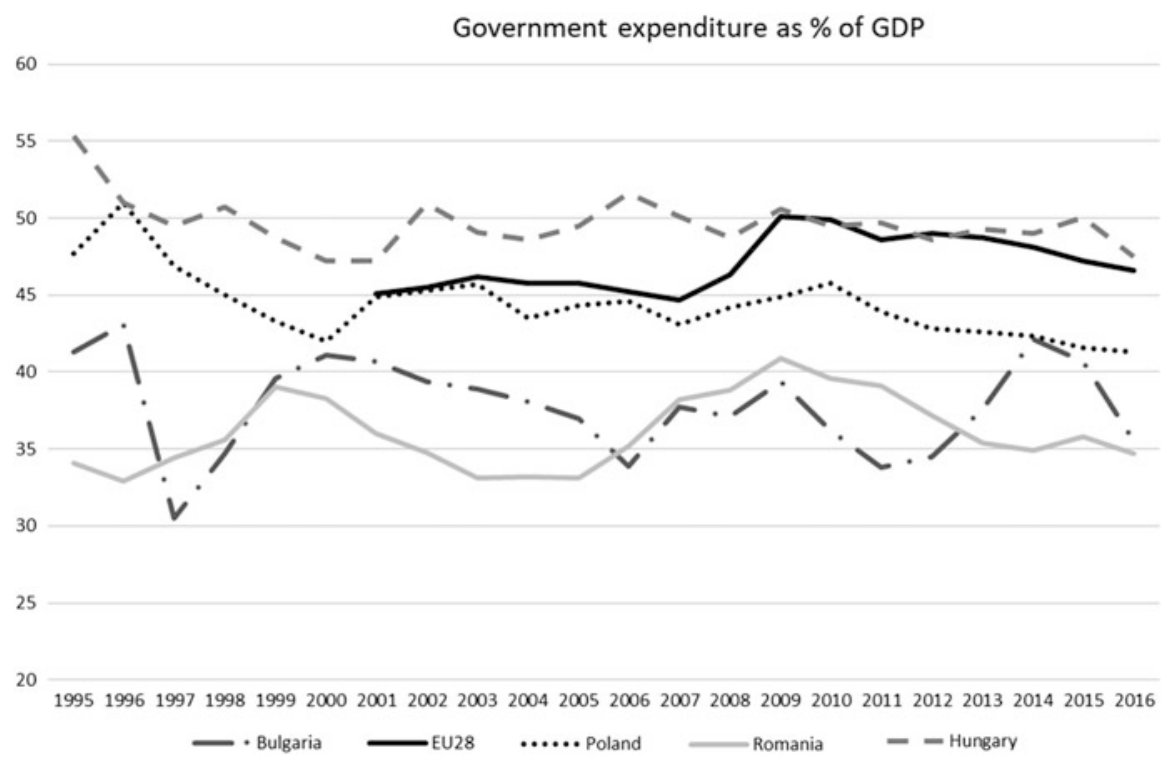

Fig. 1 Government expenditure as \% of the GDP. Source: Eurostat, Government revenue, expenditure and main aggregates (gov_10a_main), retrieved from: http://appsso.eurostat.ec.europa.eu/ nui/show.do?dataset=gov_10a_main\&lang=en, accessed November 15th, 2017

To have a broader perspective on the financing mechanisms, we must add that governmental revenues do not result directly from the size of the GDP; they are dependent on taxation. Romania's tax revenues are $15 \mathrm{pp}$. lower than the EU average (Eurostat, gov_10a_main). On average, tax revenues in the EU added up to $44.9 \%$ of the GDP in 2016 while in Romania, they equal $31.7 \%$ of the GDP. Our country collects the smallest tax revenues in its peer group (Hungary $46.2 \%$, Poland $39.1 \%$, Bulgaria 34.1\%).

In Romania, high inequality negatively affects cohesion and solidarity, especially when regional differences are considered. Since the 1990s, when Romania transitioned to a market economy, the difference between its wealthiest and poorest region increased constantly. In 1995, Bucuresti-Ilfov (the richest region) had a GDP 1.6 times higher than the poorest region (South-West Oltenia). In 2007, when Romania became an EU member, the difference was 3. In 2014, Bucuresti-Ilfov had a GDP 3.7 higher than South-West Oltenia, suggesting the failure of the cohesion policies (National Institute of Statistics in Romania, Regional gross domestic product (RGDP)—current prices calculated according CANE Rev.1 (1995-2008) \& CANE Rev.2-ESA 2010 (2000-2014).

Romania's regions contribute to the national GDP in an unbalanced manner. In 2000, Bucuresti-Ilfov accounted for 23\% of the GDP whereas the other regions accounted for from 9 to $12 \%$ (Fig. 2). Following the economic crisis, the contribution of each region to the GDP stalled, decreased or rose very slightly. The notable 


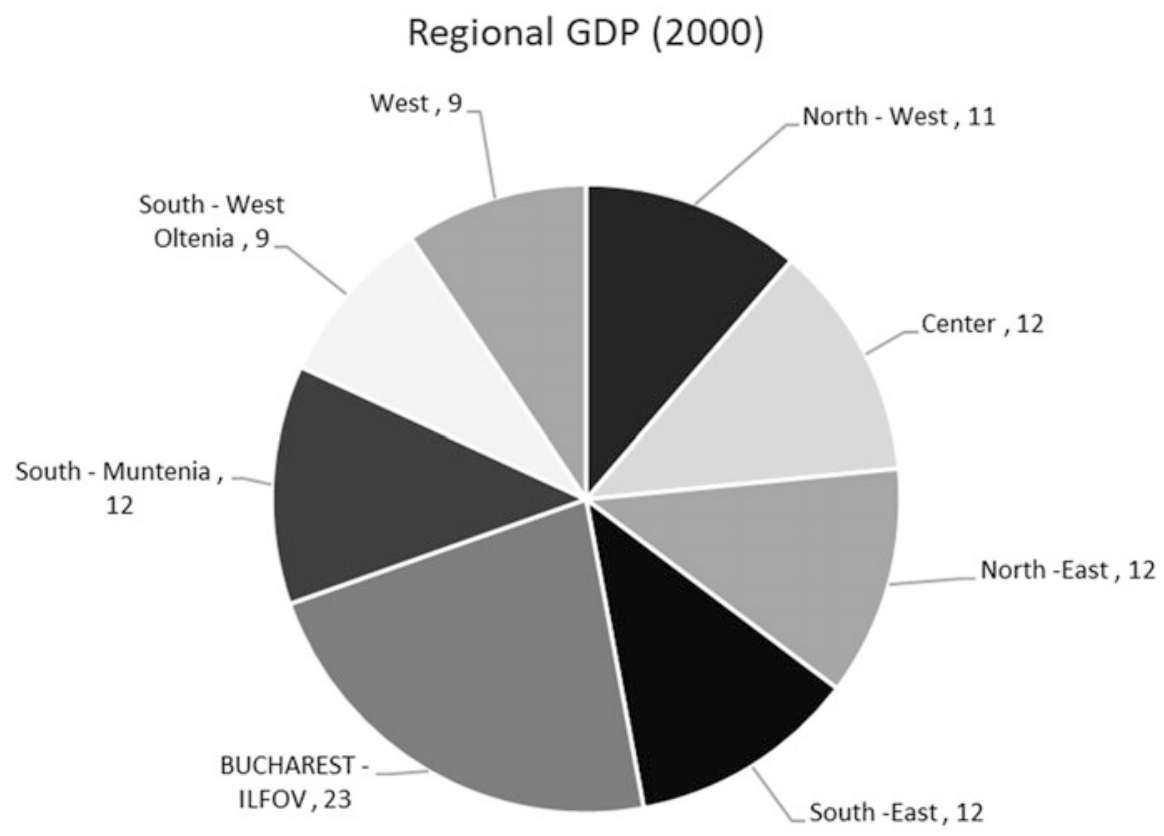

Fig. 2 The contribution of the NUTS2 regions to the national GDP (\%)-Year 2000. Source: National Institutite of Statistics (Regional gross domestic product (RGDP)—current prices, calculated according CANE Rev.2-ESA 2010, authors' calculations. Retrieved from: statistici.insse.ro, accessed November 15th, 2017

exception is the region Bucureşti-Ilfov, whose contribution to the GDP rose by 4 pp., now accounting for from $23 \%$ to $27 \%$ of the national GDP (Fig. 3).

The hallmark of development should be closing the gaps in terms of economic performances between Romania's regions. Cohesion and even development form the backbone of any given national community. The gaps in economic development lead to a troubling accumulation of distrust and discontent.

Another persistent gap is the one between urban and rural areas. The GDP/capita of the rural areas is significantly lower. In 2007, the urban area had a GDP/capita 3.2 times higher than the rural area (EUR13,000 versus EUR4000). In 2014, we find the gap unchanged (EUR16,000 versus 5000) (Source: Eurostat, urt_10r_3gdp). The intermediate (small urban) segment shows more similarities to the rural area than to the urban one. Figures prove that the economic vitality is concentrated in and around Romania's large cities whereas the rest of the country remains significantly poorer.

With the aid of statistical data, we painted a portrait of inequality in Romania; however, public perceptions are equally important. How do regular citizens feel about inequality? Do they perceive Romania's development gaps? Some insights can be found in a recent survey contracted within the EU-funded project The State of the Nation. The development of an innovative instrument for grounding the development of public policies in Romania. The survey was conducted in September 2017 


\section{Regional GDP (2014)}

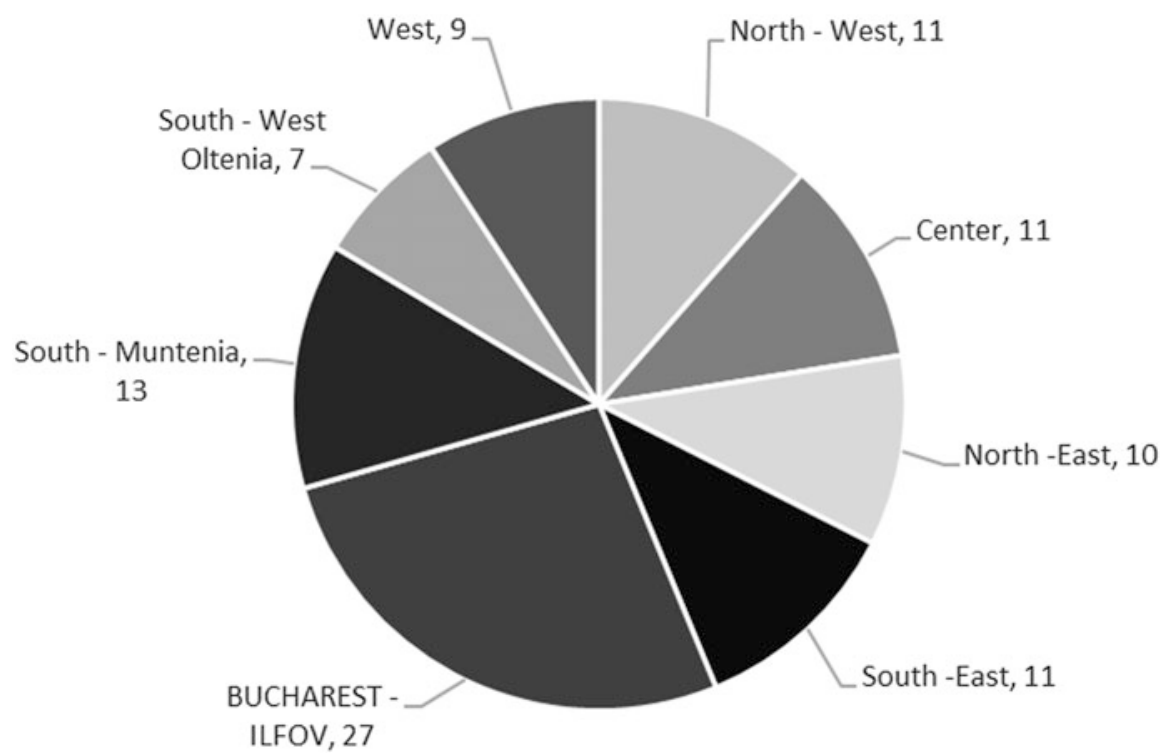

Fig. 3 National Institute of Statistics, The contribution of the NUTS2 regions to the national GDP (\%)—Year 2014. Source: INS (Regional gross domestic product (RGDP)—current prices, calculated according to CANE Rev.2-ESA 2010, authors' calculations. Retrieved from: statistici.insse.ro, accessed November 15th, 2017

on a representative sample of 1107 respondents. The majority of Romanians perceive strong inequalities between their country and others. The respondents feel their standard of living is worse than the standard of living of citizens from the developed EU countries $(82.2 \%)$ as well as other CEE countries $(76.9 \%)$. There are more Romanians who feel that EU membership improved Romania's economic situation to a small extent (47.9\%) than Romanians who believe that Romania's economy performs better after accession (44.3\%). These results mirror to some extent the actual data given that Romania's GDP decreased sharply shortly after accession (under the impact of the economic crisis) and recovered very slowly. Despite constant access to cohesion funds before and after the accession, the development gaps in Romania persist and citizens seem to be well aware of this, especially at the individual level. While $40.2 \%$ of respondents believe they have a better standard of living than the average person, $31.7 \%$ feel they are worse. The percentages remain almost unchanged when asked to think how EU membership impacted their standard of living (42.8\% "better" and 37.5\% "worse"). Lastly, we find it striking that Romanians lost hope as far as upward social mobility is concerned: $88.9 \%$ of respondents think it is difficult or extremely difficult for a person to achieve a higher social status today. 


\section{Inequality and Development in Romania: Worrying Trends}

As illustrated in the previous section, many scholars and public figures consider inequality bad for development. The former USA president Barack Obama (2016) emphasized that inequality makes vertical social mobility very difficult. Piketty (2014) warned us of the risk of the present devouring the future, and democracy losing its control over capitalism. Mervyn King (2016) wrote about "the paradox of policy - where policy measures that are desirable in the short term are diametrically opposite to those needed in the long term".

The evolution of inequality in Romania illustrates a similar truth: not only is there a risk of the present devouring the future, the mere idea of preparing for a better future has been blatantly ignored. During the last three decades, Romania's path for development has been hesitant and subjected to frequent shifts. Romania has become a country of contrasts and cleavages, in need of a vision for the future.

The issue at hand is not necessarily the complete lack of vision but building upon the wrong vision. The result? A regrettable delay of Romania's progress. One manifestation of this wrong vision is the belief that a country's evolution does not need to follow a centralizing strategy to ensure the macro balance. A recent report by the Research Institute for the Quality of Life in Romania (Zamfir 2017) emphasizes one fundamental weakness in the last 30 years: the false belief that social well-being is the result of economic growth. There was little understanding and little emphasis on the importance of going beyond the GDP. We agree that quality of life, as well as inclusive development, rely on economic performance; nevertheless, the best results can be achieved only with sustainable, reasonable and well thought-out public policies that draw on a country's priorities for development. Without these policies, life in Romania remains unsatisfactory despite its promising economic growth.

In the last 30 years, Romania has experienced moderate economic growth and, unfortunately, little development. By "development", we envisage a harmonizing process that brings social and economic issues together and provides a clear and unique vision of the economic and social life of a nation. We envisage a process that carefully considers Romania's potential for consumption, and adjusts its production to prevent unbalances in this fundamental economic relation. We will provide the reader with a few examples. Between 2007 and 2016, the GDP increased to 36\% while the number of individuals at risk of poverty and social exclusion decreased to only $18 \%$. Furthermore, the percentage of people in this situation is rose from $37.4 \%$ in 2015 to $38.8 \%$ in 2016 (Georgescu 2017). Another example shows that Romania exports unprocessed goods (in this case, cereals) and imports highly processed ones (in this case, meat) (National Institute of Statistics, EXP102D and EXP101E). This economic behavior is commonly seen in underdeveloped economies. Lastly, Romania undertook a massive deindustrialization only to make efforts to restart its industrial activity later; the new production units produce goods with small added value. Romania is falling deeper and deeper into what is called in the literature the 
medium income trap. The country is paving the road in the medium development range instead of aiming towards becoming a highly developed country.

A coherent and inclusive vision is a state attribute; only the state can act on behalf of the whole. We consider a state should be entrepreneurial and intelligent. Consequently, we believe the state should rethink its role and responsibilities. "The relationship between states and economic activity is constitutive not incidental" (Calhoon 2015, 219). The state should act in the realm of strategic thinking.

In its quest for development, Romania is pressured by its demographic evolution. The total fertility rate (average of 1.6 children per woman in 2015) is significantly lower than the minimum need for a preserving its population (2.2 children) (Eurostat, demo_frate). Furthermore, Romania has the highest number of migrants in Europe. In 2016, 207,578 people left the country (National Institute of Statistics, accessed 2018, POP320A), contributing to the three million migrants that fled Romania in the last 30 years. We can anticipate scarcity in the labor force, especially in some regions; this situation will affect labor productivity and development.

Other factors can be considered as well. As far as education is concerned, Romania experienced a decrease, to approximately $91 \%$, in enrolment rates for primary, lower secondary and upper secondary levels of education (UNESCO, Gross enrolment rates by level of education) and the highest rate of early school leavers in the EU (18.6\% in 2016-Eurostat, edat_lfse_30). Coupled with a low healthy life expectancy at the age of 65 (Eurostat, hlth_hlye_h and hlth_hlye), we see that Romania is facing a demographic crisis.

What seemed to be a temporary solution for some (working abroad for a while then returning home) became a more permanent one (leaving without wanting to return). The demographic crisis will soon happen, and when it does, it will affect the functioning of society in its entirety. Is the process of severe inequality reversible? We would like to respond in Mervyn King's words (2016): Maybe, with the audacity of pessimism.

\section{References}

Calhoon, C. (2015). Care sunt în prezent amenințările la adresa capitalismului. In I. Wallerstein, R. Collins, M. Mann, G. Derlugian, \& C. Calhoon (Eds.), Are capitalismul un viitor? Bucharest: Comunicare.ro Publishing House.

Dalton, P. S., Ghosal, S., \& Mani, A. (2015). Poverty and aspirations failure. The Economic Journal, 126(590), 165-188.

DeLong, B., Boushey, H., \& Steinbaum, M. (2017). Introduction. Capital in the twenty-first century, three years later. In H. Boushey, J. DeLong, \& M. Steinbaum (Eds.), After Piketty: The agenda for economics and inequality. London: Harvard University Press.

Ermisch, J., Markus, J., Smeeding, T., \& Wilson, J. (2012). Advantage in comparative perspective. In J. Ermisch, M. Jäntti, \& T. Smeeding (Eds.), From parents to children (pp. 3-31). New York: Russell Sage.

Georgescu, F. (2017). Creșterea economică, dezvoltarea României și reducerea sărăciei [Economic growth, Romania's development and reducing poverty]. Accessed November 11, 2017, from http://www.bnr.ro/Prezentari-si-interviuri\%2D\%2D1332.aspx?fld_issue_year=2017 
Graham, C. (2017). Happiness for all? Unequal hopes and lives in pursuit of the American dream. Princeton, NJ: Princeton University Press.

Jerrim, J., \& Macmillan, L. (2015). Income inequality, intergenerational mobility, and the Great Gatsby Curve: Is education the key? Social Forces, 94(2), 505-533.

King, M. (2016). The end of alchemy, money, banking and the future of the global economy. London: Little, Brown.

Krueger, A. (2012). The rise and consequences of inequality in the United States. Remarks for the Center for American Progress. Accessed March 12, 2018, from http://www.whitehouse.gov/ sites/default/files/krueger_cap_speech_final_remarks.pdf

Lagarde, C. (2015). Lifting the small boats. Address at Grandes Conferences Catholiques, June 17, 2015. Accessed March 26, 2018, from https://www.imf.org/en/News/Articles/2015/09/28/ $04 / 53 / \mathrm{sp} 061715$

Milanovic, B. (2016). Global inequality: A new approach for the age of globalisation. Cambridge: Belknap Press of Harvard University Press.

Obama, B. (2016). The way ahead. The Economist, October 8th, 2016. Accessed April 18, 2018, from https://www.economist.com/news/briefing/21708216-americas-president-writes-usabout-four-crucial-areas-unfinished-business-economic

Piketty, T. (2014). Capital in the twenty-first century. Transl. Arthur Goldhammer. Cambridge: The Belknap Press of Harvard University Press.

Pope Francis. (2016). An economy of exclusion and inequality, May 13, 2016. Accessed March 15, 2018, from http://www.osservatoreromano.va/en/news/economy-exclusion-and-inequality

Zamfir, C (Ed.). (2017). Starea socială a României. Calitatea vieții: situația actuală şi perspective pentru 2038. Special Report of the Research Institute for the Quality of Life in Romania.

\section{Online Sources}

The State of the nation. The development of an innovative instrument for grounding the development of public policies in Romania. Accessed April 12, 2018, from http://starea-natiunii.ro/ index.php/en/

Open Access This chapter is licensed under the terms of the Creative Commons Attribution 4.0 International License (http://creativecommons.org/licenses/by/4.0/), which permits use, sharing, adaptation, distribution and reproduction in any medium or format, as long as you give appropriate credit to the original author(s) and the source, provide a link to the Creative Commons licence and indicate if changes were made.

The images or other third party material in this chapter are included in the chapter's Creative Commons licence, unless indicated otherwise in a credit line to the material. If material is not included in the chapter's Creative Commons licence and your intended use is not permitted by statutory regulation or exceeds the permitted use, you will need to obtain permission directly from the copyright holder.

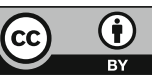




\section{Part II}

Challenges and Opportunities for Development in the Post-Crisis Period 


\title{
The East-West Divide in the European Union: A Development Divide Reframed as a Political One
}

\author{
Alina Bârgăoanu, Raluca Buturoiu, and Flavia Durach
}

\section{A World in Flux}

This chapter focuses on the return of the East-West divide in the European Union, which is fuelled by persistent differences in the level of development of the Old (Western) Member States (OMS), and the New (CEE) Member States (NMS), and fuels the major geopolitical shifts shaking the current world order.

The world we live in is "a world in flux", as Verbeke (2017) aptly describes it, and the European Union does not appear to be in a position to evade this esprit du temps. Events of the past decade, such as the discussion about Grexit in the context of the Greek bailouts, the calls for burden sharing inside NATO, the Brexit referendum and its aftermath, the interruption of TTIP negotiations, the new foreign policy of the Trump administration and its drive towards bilateralism at the expense of multilateralism have signalled deep changes in the transatlantic world and the liberal order it embodies, with a major impact on the EU as one of the biggest beneficiaries of the post-WWII order.

What makes the European Union vulnerable to these contemporary developments (especially "America first" and the drive towards multilateralism) is, among other things, its increasing lack of cohesion and convergence. The euro crisis that started in 2007 brought about a pan-European desolidarisation and fragmentation both across and within member states. At first, the fault lines symbolically separated the

This chapter has been prepared with financial support granted in the project "State of the Nation. Designing an innovative instrument for evidence-based policy-making" (SIPOCA 11, MySMIS 118305), which is co-financed by the European Social Fund through the Operational Programme Administrative Capacity 2014-2020.

\footnotetext{
A. Bârgăoanu $(\varangle) \cdot$ R. Buturoiu $(\varangle) \cdot$ F. Durach $(\bowtie)$

flavia.durach@comunicare.ro

National University of Political Studies and Public Administration, Bucharest, Romania

e-mail: alina.bargaoanu@comunicare.ro; raluca.buturoiu@comunicare.ro; 
highly-performing, expert-oriented, fiscally disciplined North and the indebted, import-oriented and fiscally "exuberant" South. Over time, more and more divides have surfaced, such as elites vs citizens, euro vs non-euro, Schengen vs non-Schengen, arrival vs destination countries and Great Britain vs everybody else.

The refugee crisis and Brexit have brought about a new divide, which builds on the existing ones and amplifies them in a dramatic manner-the East-West divide. In our opinion, it is the most dramatic divide inside the European Union for several reasons. As we said, it builds on the previous divides and escalates them; it has acquired political overtones ("liberal" vs "illiberal"); it is "underwritten" by real development gaps, which can be overcome only in the long term; and it has a special geopolitical significance since it is a divide emerging at the Eastern frontier of the $\mathrm{EU}$, traditionally a crossroads of geopolitical interests. What appeared as a financial divide brought about by different fiscal policies is now morphing into a geopolitical crisis of the EU.

\section{The Eastward Enlargement: A Transition from One International Regime to Another}

The eastward enlargement meant the largest expansion of the EU in terms of territory, number of states and population. Apart from the initial enthusiasm and the obsessive, highly ideological discourse focused on the "export of Western norms and values to the former communist countries", what created the greatest challenge was the attempt to close the economic/development gaps between the Western and the Eastern part of the EU. Around the time of accession of the new Eastern members, some scholars warned against a greater heterogeneity of the EU, making room for conflicts over diverging different national policy objectives, economic structures and potentials, financial constraints and societal preferences (Ahrens et al. 2005; Krätke 2002).

Enlargement was described as following an "imperial pattern" (Zielonka 2006, 2008). Instead of replicating the traditional Westphalian nation-state model on a larger scale, Zielonka (2006, 2008) argues that the EU acts as a neo-medieval empire, with a meta-governor (the central EU institutions) and accommodates changing borders and diversity. In a sense, Eastern Europe experienced a transition not from authoritarian communist regimes to democracy but from one international regime to another (Janos 2001). The new order entrenched in the enlargement policy reflected the interests and identity of the new hegemon: security in the Eastern vicinity, a need to pre-empt political chaos, the need to demonstrate the universal relevance of liberal projects (Janos 2001).

The discussion about the patterns of EU integration in CEE countries is further confounded by the fact that there are persistent asymmetries in the relations between the Western and Eastern parts of the European Union (Epstein and Jacoby 2014). The less-than-favourable attitudes of Western Europe towards CEE states precede 
the moment of enlargement, the fall of communism and even the Cold War. "In some sense, the forsaking of ECE following World War II came naturally for West European and American leaders, many of whom viewed the East as politically, economically and culturally distinct-and importantly, inferior" (Epstein and Jacoby 2014, p. 3).

These patterns are painfully obvious in the recent conflict between Brussels and Poland (the "poster child of EU integration" until not long ago). It is the particular choice of words that reveals the East-West divide: innuendos on Poland's unwillingness to solve the issue by means of dialogue (Austrian Federal Minister Gernot Blümel); a power-asymmetry implied when Poland is expected to "provide explanations" (Commission vice-president Frans Timmermans), like a scolded child; the Swedish minister arguing that the issue of rule of law is about the credibility of the entire EU. Poland alludes to discrimination: "We would like member states to approach the Polish evaluation of justice reforms with the same attention, trust and impartiality" (head of Polish diplomacy, Konrad Szymański). Thirteen or ten years, respectively, after the historic reunification of Europe through EU enlargement (2004, 2007), the sources of discontent between the newcomers and the established members are neither few nor easy to solve.

Why was it so easy for the East-West divide to return? In our view, the main reason is that the two halves of the EU function in rather different socio-economic realities, leading, in turn, to different expectations regarding European integration. For the remainder of this chapter, we will analyse the East-West divide from the perspective of development gaps, arguing that while this divide has political, historical and even perceptual overtones, its main driver is developmental, being socio-economic in nature.

It is beyond doubt that NMS were able to take advantage of the many benefits created by EU enlargement: securing high volumes of foreign investment (FDI), access to markets, GDP increase, greater prosperity, modernisation of the service sector, improvements in human capital, and modernisation of part of their infrastructure. At the same time, this new openness to liberal/Western capital has brought about new challenges: vulnerability to external economic shocks (Medve-Bálint 2014), diminished capacity for autonomous innovation and efficiency of the domestic firms (Epstein 2014) and a huge displacement of the working population to the richer parts of the EU (as experienced especially by Romania and Poland).

Despite undisputable economic progress-for example, catching-up in terms of GDP per capita, as noted by Goedemé and Collado (2016)_NMS have been lagging behind in social issues such as minimum wage, expenditures on social protection, life satisfaction, poverty, deprivation, income inequality, unemployment, and mortality (Aidukaite 2011). Furthermore, the NMS of CEE and Baltic countries have the highest levels of aggregate risk of chronic relative material deprivation while Northern and Continental European countries have the lowest levels (Gábos and Goedemé 2016).

Another limitation worth discussing in relation to CEE membership to the EU is that the supranational organism is poor in its provision for distribution of wealth and 
prosperity - both across the EU and within member states. With respect to convergence between member states, macroeconomic data suggest that, while the EU's "convergence machine" turned many low-income and middle-income countries into high-income economies, the 2009 economic crisis turned convergence into divergence. Income differences between the EU-15 and the NMS remain substantial. The national median income of many EU-15 countries is relatively close to the EU-wide median income, whereas the median income in the NMS is generally substantially lower than the EU-wide median income (Goedemé and Collado 2016). As far as intra-national convergence is concerned, while many regions in CEE countries are likely to slowly catch up with their Western neighbours, they leave others behind in relative poverty in the process (Bosker 2009).

\section{The East-West Divide in Data}

Our research investigates the return of the East-West divide in the EU from the perspective of development and progress. Our research is premised on the idea that the main driver of this divide is the socio-economic one and it seeks to show that CEE membership to the EU has left largely untouched development indicators such as the urban-rural ratio, level of capitalisation and savings, entrepreneurship and innovation, integration in global/European production, technology, R\&D chains, the minimum wage, social expenditures, poverty, deprivation, income inequality, unemployment, and mortality.

Our research will underline the morphology of the East-West "development divide" by focusing on its socio-economic determinants. We will use institutional data sources such as Eurostat, the World Bank, and the United Nations and we will apply secondary data analysis to compare and discuss the development patterns in OMS and NMS. Specifically, our objective is to identify the differences in development based on the following interconnected (a) economic indicators: real GDP per capita, GDP per capita in Purchasing Power Standards (PPS), final consumption expenditure as a percentage of GDP, net national income, minimum wages, foreign direct investments, and (b) social indicators: migration by country of origin, life expectancy at birth, healthy life years at birth, healthy life years at the age of 65, human development index, and the world happiness report. This part of the research will seek to clarify that, in NMS and elsewhere, economic growth is not an interchangeable word for development, which is simultaneously an economic, social, political, and cultural phenomenon (Goldin 2016).

The timeframe for this empirical research is 1990-2018, covering several milestones: the fall of the communist regime in Central and Eastern European countries, the completion of the eastward enlargement, the euro crisis, the Ukraine crisis, the refugee crisis, and Brexit. The timeframe also depends on data availability at the time of writing this chapter. Throughout our chapter, we define the OMS as the founding members, plus the countries from the first, second and third enlargement waves, plus two Mediterranean countries which joined the EU in 2004 (i.e., Germany, France, 
Italy, Luxembourg, The Netherlands, Belgium, Denmark, the UK, Ireland, Greece, Spain, Portugal, Austria, Finland, Sweden, Cyprus, and Malta); all also referred to as the EU's Western part. By contrast, the NMS are referred to as the countries that joined the EU in 2004, 2007 and 2013 - predominantly former communist countries from the EU's Eastern periphery (i.e., the Czech Republic, Estonia, Hungary, Latvia, Lithuania, Poland, Slovakia Slovenia, Romania, Bulgaria, and Croatia). We chose to create these two clusters because they reflect, both pragmatically and symbolically, the East-West divide that is the focus of this research.

\subsection{Economic Development Patterns}

One indicator revealing how well off a country is, and thus explaining a country's level of development, is real GDP per capita. The indicator is calculated as the ratio of real GDP to the average population of a specific year, meaning that it measures the average real income specific to a country. Figure 1 shows the average of real GDP per capita by comparatively analysing the trends of real GDP averages in NMS and OMS.

Data reveal that there is an obvious economic development gap between the NMS and the OMS. The difference in the average of real GDP per capita between NMS and OMS is consistent over time, despite European integration. In 2016, the average value of GDP per capita in NMS (12,136 €/capita) was around third times lower than that in OMS $(34,835 € /$ capita). Ironically enough, the economic benefits of $\mathrm{EU}$ membership seem to be rather meagre. Although the EU structural and cohesion funds were highly available starting from 2007, and the NMS succeeded in contracting them (for an overview, see the KPMG report 2016), the economic performance of these countries did not seem to significantly improve over time.

In order to get a better image about cross-country economic performances, one should look at the volume index of GDP per capita in PPS. The indicator is expressed in relation to the European Union (EU28) average set to equal 100. If the index of a country is higher than 100, that country's level of GDP per capita is higher than the EU

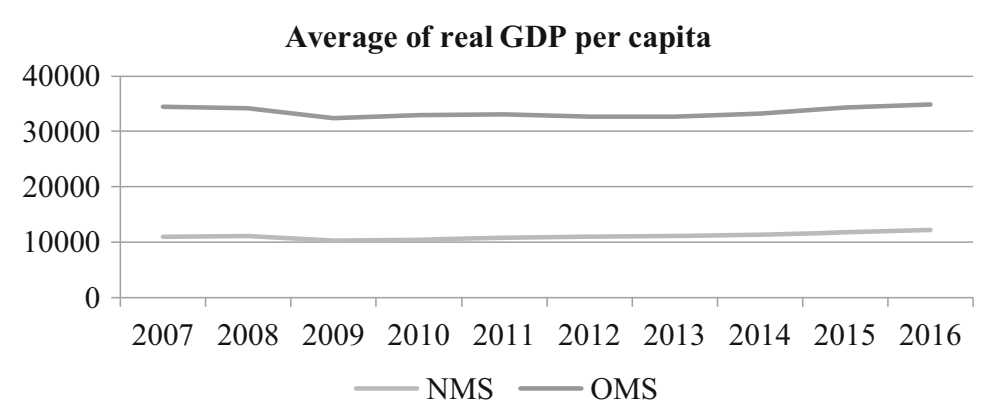

Fig. 1 Average of real GDP per capita in NMS and OMS. Source: Eurostat, variable tsdec100. Retrieved from: https://ec.europa.eu/eurostat/web/products-datasets/-/tsdec100, accessed April 10th, 2018 
average and vice versa. Data for 2016 show that there is a clear divide between OMS and NMS in terms of GDP per capita in PPS (Eurostat, variable tec00114, accessed 2018). OMS register values significantly higher than the EU28 average (100), while NMS register lower values. Broadly, the top part of the ranking consists of OMS while the bottom part is dominated by NMS. Specifically, the top five EU countries in terms of GDP per capita in PPS are Luxembourg (258), Ireland (183), The Netherlands (128), Austria (128), and Denmark (124), whereas the last ranked five countries are Bulgaria (49), Romania (58), Croatia (60), Latvia (65), and Hungary (67). We can notice that there is a huge difference of performance across countries-Bulgaria has an index of GDP per capita in PPS five times lower than Luxembourg's.

At first glance, a consumption boom can be considered a measure of well-being and progress for the CEE member states. What we find worrying is that consumption levels in the NMS are similar to those in the advanced economies while income levels are significantly lower. Citizens in NMS make efforts to improve their way of living to meet Western standards by collecting debt or by cutting down on savings. To analyse this trend, we turned to the indicator "final consumption expenditure as percentage of GDP" (Eurostat, variable nama_10_gdp, accessed 2018). Final consumption expenditure is expenditure by resident institutional units-including households and enterprises whose main economic centre of interest is in that economic territory-on goods or services that are used for the direct satisfaction of individual needs or wants or the collective needs of members of the community. In 2016, consumption levels in NMS were similar to those in OMS while having significantly lower income levels. For example, the top five NMS in terms of final consumption expenditure as percentage of GDP-Lithuania (81.5\%), Latvia (79.5\%), Croatia (77\%), Romania (76.9\%) and Bulgaria (76.55\%)—have consumption levels similar to OMS whose net national incomes and GDP levels are considerably higher-for example, Italy $(79.6 \%)$ and Finland $(79.1 \%)$ (Eurostat, variables tsdec230 and nama_10_gdp, accessed 2018). This pattern in consumption expenditure is a measure suggestive of the centre-periphery relations in which the latter tries to mimic the standard of living, level of progress and innovation of the centre without actually managing to catch up in terms of economic performances.

Another important indicator of economic development is the monthly minimum wages $^{1}$ in PPS and in euro (Eurostat, variable earn_mw_cur, accessed 2018). Figure 2 shows the average of minimum wages, as of 1 January 2018, in PPs and in euro, by comparing NMS with OMS.

Data show a significant gap between the average value of minimum wages in NMS and OMS. Bulgaria registers the lowest value of minimum wage as of 1 January 2018 (261 €), followed by nine other NMS, also located in Central and Eastern part of the EU, which register minimum wage values between $400 €$ and $500 €$. On the other side, there are the old EU countries where the value of the minimum wage is much higher. For example, in Luxembourg, Ireland, The

\footnotetext{
${ }^{1}$ Twenty-two out of the 28 Member States of the European Union have national minimum wages. Only Denmark, Italy, Cyprus, Austria, Finland, and Sweden do not.
} 
Average of minimum wages - as of 1 January 2018, in PPS and in euro

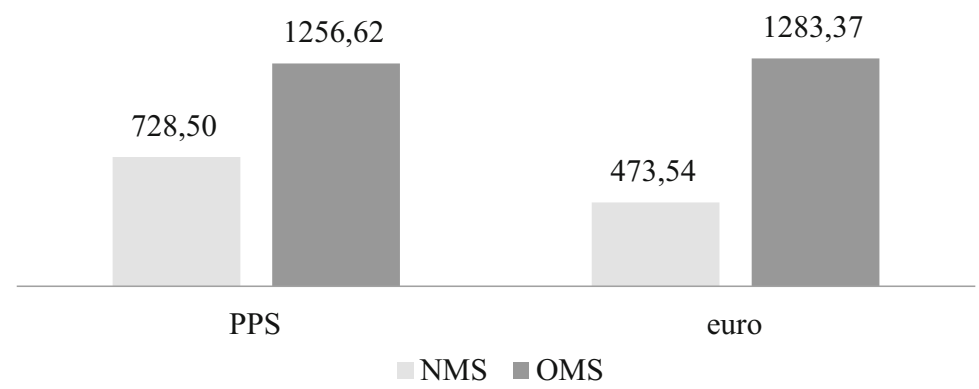

Fig. 2 Average of minimum wages, as of 1 January 2018, in PPS and in euro in NMS and OMS. Source: Eurostat, variable earn_mw_cur. Retrieved from: http://appsso.eurostat.ec.europa.eu/nui/ show.do?dataset=earn_mw_cur\&lang=en, accessed February 15th, 2018

Netherlands, and Belgium, the minimum wage values vary between $1500 €$ and $2000 €$. Therefore, we can notice major disparities between the NMS and OMS; the average value of minimum wages is around $500 €$ in NMS and almost three times higher in OMS (1300 €). The situation is more dramatic if we take into consideration that the lowest minimum wage (Bulgaria, $261 €$ ) is almost eight times lower than the highest (Luxembourg, $1999 €$ ). When price level differences are eliminated, the divide seems to be attenuated - the average value of minimum wages in PPS is almost two times lower in NMS than in OMS (729 PPS in NMS and 1257 PPS in OMS). By eliminating price differences, minimum wages range from 546 PPS per month in Bulgaria to 1597 PPS in Luxembourg, meaning that the highest minimum wage is almost three times higher than the lowest; thus revealing a smaller gap.

The minimum wage, whose purpose is to protect employees from excessively low pay, is one way to ensure a more equitable share of the revenues and a means to overcome poverty and inequality. The aforementioned differences in minimum wages between OMS and NMS are a sign of divergence. As data suggest, while the minimum wage enforces a minimal standard of remuneration, its value largely depends on where in the EU the worker is based. This reinforces the East-West discrepancies, especially for vulnerable socio-demographic categories such as manual labourers and low-skilled workers living on minimum wages and is, in turn, linked to the economic migration fluxes from Eastern to Western countries.

In order to get a thorough understanding of the economic development gap between NMS and OMS, we will discuss foreign direct investments (FDI). If in other indicators, such as real GDP per capita and minimum wages, there is a clear divide between OMS and NMS in terms of achievements, FDI results suggest the attractiveness of CEE states for foreign investors. NMS manage to outperform some OMS as far as FDIs are concerned, as we will elaborate below. Data from 2016 show that some OMS (Luxembourg-45.81\%, Ireland-25.97\%, Malta-22.17\%, The Netherlands-19.81\%, Cyprus-13.01\%, and United Kingdom-11.07\%) register 
significantly higher values of foreign direct investment as a percentage of GDP than NMS (foreign direct investment, net inflows (\% of GDP), World Bank, variable BX. KLT.DINV.WD.GD.ZS, accessed 2018). According to the 2017 World Investment Report, the UK and The Netherlands are among the top five host economies in the world (together with the United States, Canada and Australia) in terms of FDI flows. In general, top countries attracting foreign investment are mainly situated in the OMS cluster. We notice as an exception the situation of Hungary, ranking first in 2016 in terms of highest foreign direct investment (54.6\%), mainly due to the support of the Hungarian Investment Promotion Agency (HIPA) ${ }^{2}$. Generally, NMS register values between $2.2 \%$ and $4 \%$, thus outweighing OMS such as Denmark (2.09\%), Greece $(1.59 \%)$, Germany $(1.51 \%)$, France $(1.43 \%)$, Italy $(0.99 \%)$, Finland $\left(-4 \%{ }^{3}\right)$ and Austria $(-7.66 \%)$ in terms of foreign direct investment in 2016.

Nevertheless, high levels of foreign direct investment in NMS countries do not seem to have led to indirect long-term benefits. While direct effects-upgrades in receiving foreign capital - are visible for NMS, indirect effects-including increasing competitiveness and the development of nationally-based companies that could compete with foreign-owned ones-are still flimsy. As Epstein (2014, p. 25) argues, "Indirect effects are arguably more important for the question of backwardness, since they affect a recipient country's capacity to develop autonomous innovation". In more general terms, the overall benefits did not transpose into higher levels of social equity and hence did not really contribute to lower levels of inequality; overall performances registered by NMS are still modest in comparison with those from OMS. Furthermore, as shown in previous sections, local firms are unable to compete with multi-national ones since they did not build the pathways for research and development, innovation, and human capital improvement. Excessive reliance on foreign capital damages a country's development by maintaining a dependency on an external "centre".

Data stemming from the economic development indicators we considered confirm the sources of what Janos (2000) called the "economic backwardness" of CEE. Here, multiple issues overlap, from the inability to take full advantage of foreign investments to lagging behind in terms of GDP or in the capacity of the economy to support a certain level of minimum wage without increasing unemployment or bankruptcies.

Furthermore, there is a subtler hierarchy (or development gap) inside NMS as well, a multi-tier pattern which is becoming more evident as one travels from Western Europe to the Czech Republic and Poland, and then further east and south. In other words, the development divide is not only between the OMS and

\footnotetext{
${ }^{2}$ For more details, see Hungarian Investment Promotion Agency (2017). Retrieved from: https:// hipa.hu/foreign-investors-continue-to-trust-in-hungary, accessed February 27, 2018.

${ }^{3}$ According to Eurostat, 2017, negative FDI values indicate where outflows of investment exceed inflows. This may indicate, for example, disinvestment, or reinvestment outside the country, discharges of liabilities, advance and redemption of inter-company loans, short-term credit movements, company dividends exceeding recorded income over a given period, or company operations being at a loss.
} 
NMS but also within the NMS cluster. For example, in 2016, Slovenia (18,500 €/ capita) and the Czech Republic (16,500 €/capita) had a real GDP per capita almost three times higher than Bulgaria (6000 €/capita) and over two times higher than Romania (7700 €/capita). In terms of minimum wages in euros on 1 January 2018, we can notice that in Slovenia ( $843 €$ ) the minimum wage is the highest among the NMS, this value being over three times higher than that in Bulgaria (261 €) and around two times higher than that in Lithuania (400€), Romania (408€) and Latvia (430 €). One explanation for this intra-NMS divide could be that the proximity to the core of Northwest Europe facilitated the accession and use of technological innovation and, therefore, reduced the vulnerabilities of backwardness experienced by South-Eastern European countries (Epstein 2014). Our view is also supported by the findings of the project The State of the Nation. The development of an innovative instrument for grounding the development of public policies in Romania, which relies on evidence-based comparisons within Romania's peer group (other CEE countries) in order to signal regional similarities and certain development patterns as a result of EU membership. ${ }^{4}$

\subsection{Social Development Patterns}

This section of our contribution is dedicated to social development indicators. By far, one of the most significant indicators explaining the development gap between OMS and NMS is the number of migrants. Figure 3 shows the total number of migrants by countries of origin by comparatively analysing migration stock across EU countries.

It is observable from the chart that soon after the fall of the communist regimes in Eastern Europe (1990), the European migratory routes were mainly from OMS to other OMS. Not surprisingly, migrants chose to establish in other OMS in order to feel at home in a place similar to their own in terms of economic development. In 1990, there was insignificant migration from OMS to NMS and between countries in the CEE cluster. Fifteen years later, after the successive waves of eastward enlargement, the patterns are completely different. The number of people moving from OMS to similar countries from OMS decreased to around 2 million (from 9,826,714 in 1990 to 7,667,937 in 2015). Instead, citizens from NMS prefer to move to OMS; in 2015, almost 9 million people from NMS moved to OMS (six times more than in 1990). The freedom of movement and residence for persons in the EU, which is the cornerstone of Union citizenship, established by the Treaty of Maastricht in 1992, made it possible for citizens from CEE to move to the more attractive EU-15 states (OMS).

\footnotetext{
${ }^{4}$ For further details, see the official webpage of the Project The State of the Nation. The development of an innovative instrument for grounding the development of public policies in Romania: http:// starea-natiunii.ro/en/, accessed March 8th, 2017.
} 
Total number of migrants by countries of origin comparison 1990-2015

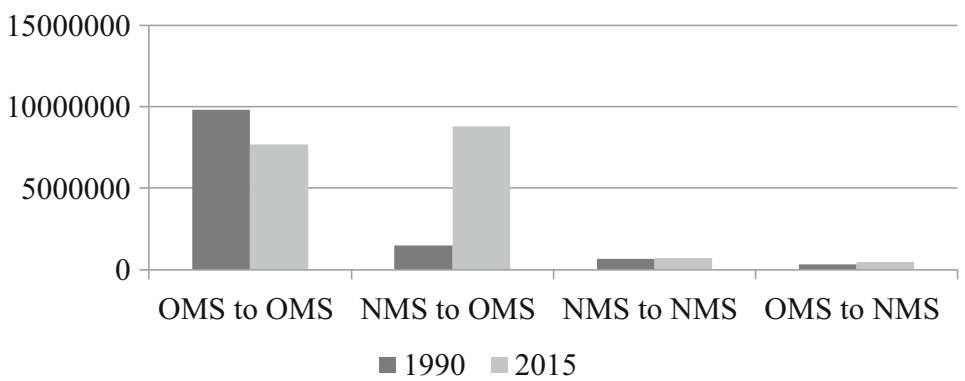

Fig. 3 Total number of migrants by countries of origin-comparison 1990-2015. Source: United Nations, Department of Economic and Social Affairs (2015). Trends in International Migrant Stock: Migrants by Destination and Origin (United Nations database, POP/DB/MIG/Stock/Rev.2015). Retrieved from: http://www.un.org/en/development/desa/population/migration/data/estimates2/esti mates15.shtml, accessed March 8th, 2018

Data show that, in general, NMS are not a favourite destination for people living in NMS or for those living in OMS. One explanation is income disparity, one of the main factors contributing to socio-economic inequality-for an overview, see the data explained above on minimum wages. Another explanation is that people are seeking stable, prosperous economies to work and live in (with high rates of GDP per capita and low unemployment rates). Hence, OMS seem the best choice.

The data are worrying, mainly because the movement of these high numbers of people from NMS to OMS entails long-term effects. Pensions, which take up about half of social spending in Eastern European countries, are the biggest worry. An article in The Economist (2017) reveals that in 2013, Latvia had 3.3 working-age adults for each person older than 65-a similar number to Britain and France. By 2030 that number is estimated to fall to just over two, a level that the UK and France will not reach until 2060.

NMS are not only lagging behind in economic terms but also concerning health and life expectancy. Life expectancy at birth represents the mean number of years that a person can expect to live if subjected to current mortality conditions throughout the rest of his or her life. Healthy life years (also called disability-free life expectancy) measure the number of remaining years that a person of a certain age should live without disability. It is a solid indicator to monitor health as a productivity/economic factor, being used to distinguish between years of life free of any activity limitation and years with at least one activity limitation. The emphasis is not exclusively on the length of life, as is the case for life expectancy, but also on the quality of life.

In general, data show that indicators related to life expectancy at birth have been on the increase during the past decade. For example, life expectancy at birth in the EU-28 increased by 2.9 years, from 77.7 to 80.6 years; the increase was 2.4 years for women and 3.4 years for men (Eurostat, variable demo_mlexpec, accessed 2018). 
This increase is due to a number of factors, including a reduction in infant mortality, rising living standards, improved lifestyles, and better education as well as advances in healthcare and medicine. However, data on healthy life years at birth (Eurostat, variable hlth_hlye, accessed 2018) are not so optimistic. Rather, the countries where healthy life years at birth increased during the last decade are exceptions. Therefore, we notice that even though life expectancy at birth increased, the number of years a person lives in good health remained similar or, even worse, decreased. Figure 4 shows a comparison between OMS and NMS in terms of life expectancy at birth and healthy life years at birth according to gender.

Data reveal that in OMS both life expectancy at birth and healthy life years at birth register higher values than in NMS. Life expectancy at birth for females is 3.5 years higher in OMS than in NMS, and for males it is 6.4 years higher in OMS than in NMS. While registering significantly lower values, healthy life years at birth registers similar differences (in years) when comparing OMS with NMS. These data, coupled with projection data on retirement age ${ }^{5}$ showing that the average age of retirement will be around $68-70$ years by 2050 , are worrying. These projections take into account the increase in life expectancy at birth and the old-age dependency while ignoring data on healthy life years at birth. In several cases, the retirement age is significantly higher than the average value of healthy life years at birth, especially for men. Even more alarming is the data on healthy life years at the age of 65 (Eurostat, variable hlth_hlye, accessed 2018). While people from OMS expect to live around ten more years in good health after the age of 65, those from NMS expect to live only around six more years.

\section{Life expectancy at birth vs. Healthy life years in absolute value at birth - data for 2015}

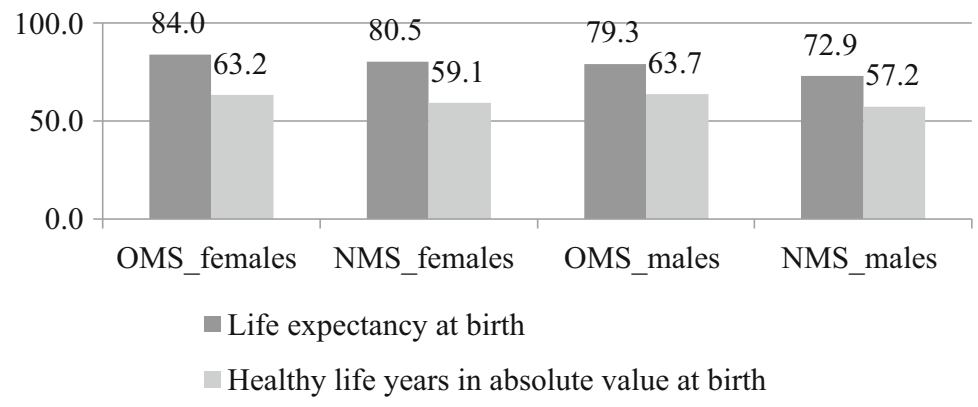

Fig. 4 Average of life expectancy at birth vs. Healthy life years in absolute value at birth according to gender-data for 2015. Source: Eurostat, variables demo_mlexpec and hlth_hlye. Retrieved from: http://appsso.eurostat.ec.europa.eu/nui/show.do?dataset=demo_mlexpec\&lang=en, and http://appsso.eurostat.ec.europa.eu/nui/show.do?dataset=hlth_hlye\&lang=en, accessed March 8th, 2018

\footnotetext{
${ }^{5}$ For details, see Finnish Center for Pensions https://www.etk.fi/en/the-pension-system-2/the-pen sion-system/international-comparison/retirement-ages/, accessed February 28th, 2018.
} 
These data could be linked to other interesting statistics on the human development index, particularly created to emphasise that people and their capabilities should be the ultimate criteria for assessing the development of a country rather than economic growth alone. The human development index (HDI) is a summary measure of average achievement in key dimensions of human development: a long and healthy life, being knowledgeable, and having a decent standard of living. In terms of HDI, 1990-2015, accessed 2018), data show that there were no significant differences between the average values of HDI in OMS and in NMS. However, data for 2015 reveal that four countries from the old EU member states are in the top ten highest ranked on HDI (very high human development): Germany (4), Denmark (5), The Netherlands (7), and Ireland (8). All the other EU countries, except Bulgaria (which ranks high on human development), are ranked as having very high human development. Despite this ranking, the divide between OMS and NMS on the other key indicators of human development is starkly visible.

\section{The East-West Divide: Consequences for the Future of the EU}

While eastward enlargement was framed as a great victory for the EU's model of development, it actually failed to reduce the disparities between OMS and NMS. More than 10 years after accession, the socio-economic differences between the Western and the Eastern states of the EU are problematic, enduring realities.

The re-emergence of the East-West divide in the EU, in even starker terms than those at the height of the Cold War, is a worrisome phenomenon. Our research was premised on the idea that the major driver of the East-West divide is that of development and sought to draw attention to the socio-economic development indicators that have been left untouched, in some situations even aggravated, by the process of European integration. We consider that a sober, critical, evidencebased acknowledgement of the European Union's failure to make significant contributions to close this development divide is worth our attention. In our view, the success or failure of the project of European integration needs to be discussed in economic terms since prosperity — shared prosperity — was the foundational value of the EU: peace and prosperity, peace as a result of prosperity to be more specific. Given its developmental, socio-economic nature, this divide is difficult to overcome since the results of major developmental, transformative projects are difficult to achieve in the short term. Besides, the EU appears to have had no such large pan-European transformative projects in hindsight.

To further confound the problem, this development divide is reframed as a political divide ("liberal" vs. "illiberal") or a civilisational one (the "cultural backwardness" of the East vs. the "moral superiority" of the West), a fact that obliterates its root causes. Besides, we are dealing with a geopolitically sensitive area, a crossroads of major geopolitical interests and trends, and the consequences of this 
socio-economic development divide, reframed as a political or even a civilisational divide, are felt in the geopolitical strategic field.

The temptation to reframe this development gap in political, cultural, or even civilisational terms is big; just as equally big appears to be the temptation to leave CEE behind and consider the eastward enlargement a geopolitical blunder. No matter how alluring this scenario might be for some short-sighted leaders, leaving CEE behind, in practical as well as in symbolic terms, may well create the greatest vulnerability for the EU and the international liberal order in the following years.

\section{References}

Ahrens, J., Hoen, H. W., \& Ohr, R. (2005). Deepening integration in an enlarged EU: A clubtheoretical perspective. Journal of European Integration, 27(4), 417-439.

Aidukaite, J. (2011). Welfare reforms and socio-economic trends in the 10 new EU member states of Central and Eastern Europe. Communist and Post-Communist Studies, 44(3), 211-219.

Bosker, M. (2009). The spatial evolution of regional GDP disparities in the "old" and the "new" Europe. Papers in Regional Science, 88(1), 3-27.

The Economist. (2017). Eastern Europe's workers are emigrating, but its pensioners are staying. Retrieved February 27, 2018, from https://www.economist.com/news/europe/21714999-eusnewest-members-face-economic-decline-unless-they-woo-back-workers-or-recruit-immigrants

Epstein, R. A. (2014). Overcoming 'Economic Backwardness' in the European Union. Journal of Common Market Studies, 52(1), 17-34.

Epstein, R. A., \& Jacoby, W. (2014). Eastern enlargement ten years on: Transcending the EastWest divide? Journal of Common Market Studies, 52(1), 1-16.

Finnish Center for Pensions. Retrieved February 28, 2018., from https://www.etk.fi/en/the-pensionsystem-2/the-pension-system/international-comparison/retirement-ages/

Goedemé, T., \& Collado, D. (2016). The EU convergence machine at work. To the benefit of the EU's poorest citizens? Journal of Common Market Studies, 54(5), 1142-1158.

Goldin, I. (2016). The pursuit of development: Economic growth, social change, and ideas. Oxford: Oxford University Press.

Gábos, A., \& Goedemé, T. (2016). The Europe 2020 Social Inclusion Indicators: Main conclusions of the ImPRovE project on validity, methodological robustness and interrelationships (No. 16/13). Herman Deleeck Centre for Social Policy, University of Antwerp.

Hungarian Investment Promotion Agency. (2017). Foreign investors continue to trust in Hungary. Retrieved February 27, 2018, from https://hipa.hu/foreign-investors-continue-to-trust-inhungary

Janos, A. C. (2000). East Central Europe in the modern world: The politics of the borderlands from pre- to postcommunism. Stanford, CA: Stanford University Press.

Janos, A. C. (2001). From Eastern empire to Western hegemony: East Central Europe under two international regimes. East European Politics and Societies, 15(2), 221-249.

KPMG Report. (2016). EU funds in Central and Eastern Europe. Progress Report 2007-2015. Retrieved February 27, 2018, from https://assets.kpmg.com/content/dam/kpmg/pdf/2016/06/ EU-Funds-in-Central-and-Eastern-Europe.pdf

Krätke, S. (2002). The regional impact of EU Eastern enlargement: A view from Germany. European Planning Studies, 10(5), 651-664.

Medve-Bálint, G. (2014). The role of the EU in shaping FDI flows to East Central Europe. Journal of Common Market Studies, 52(1), 35-51.

United Nations World Investment Report. (2017). Investment and the digital economy. Retrieved February 28, 2018, from http://unctad.org/en/PublicationsLibrary/wir2017_en.pdf 
Verbeke, J. (2017). A world in flux. EGMONT Royal Institute for International Relation. Security Policy Brief, No 02, November 2017. Retrieved February 28, 2018, from http://www. egmontinstitute.be/content/uploads/2017/11/SPB92-Verbeke.pdf?type $=$ pdf

Zielonka, J. (2006). Europe as empire: The nature of the enlarged European Union. Oxford: Oxford University Press.

Zielonka, J. (2008). Europe as a global actor: Empire by example? International Affairs, 84(3), 471-484.

Open Access This chapter is licensed under the terms of the Creative Commons Attribution 4.0 International License (http://creativecommons.org/licenses/by/4.0/), which permits use, sharing, adaptation, distribution and reproduction in any medium or format, as long as you give appropriate credit to the original author(s) and the source, provide a link to the Creative Commons licence and indicate if changes were made.

The images or other third party material in this chapter are included in the chapter's Creative Commons licence, unless indicated otherwise in a credit line to the material. If material is not included in the chapter's Creative Commons licence and your intended use is not permitted by statutory regulation or exceeds the permitted use, you will need to obtain permission directly from the copyright holder. 


\title{
New Frontiers in Sovereign Wealth Fund Capitalization
}

\author{
Juergen Braunstein and Asim Ali
}

\section{Introduction}

This contribution takes its place alongside a small but growing literature that identifies new funding streams for the creation of SWFs (e.g. see, Schena et al. 2018; Gamlen et al. 2016; Braunstein and Caoili 2016; Braunstein et al. 2016; Atkinson and Hamilton 2016). While in the past it was primarily commodity wealth or current account surpluses that funded the creation of SWFs, policy makers are increasingly looking at non-traditional sources, such as taxes, immigrant investor programs and intellectual property rents (see Clarke 2016). Reflecting this change in potential funding sources, the actors involved in the debate are becoming more diverse. While in the past it was primarily the Ministry of Finance or Central Bank that was involved in the debate, other government departments and ministries, such as innovation departments, migration ministries, state-owned enterprise (SOE) ministries, and economic and development ministries, are increasingly getting involved. The objective of this chapter is to systematize existing research and identify promising but overlooked funding sources for future SWFs.

SWFs are large state investment funds that have become important actors in the international finance arena. SWFs have traditionally been established to recycle oil/gas, budget current account surpluses, and address a number of macroeconomic issues; for example, smoothing fiscal revenues, mitigating the Dutch disease or saving for future generations, protecting against capital supply shocks, stabilizing budgets, saving for future generations, and developing financial markets (Braunstein 2018). Mirroring these objectives, SWFs have tended to invest primarily into foreign

J. Braunstein (ه)

Harvard Kennedy School's Belfer Center, Cambridge, MA, USA

e-mail: juergen_braunstein@hks.harvard.edu

A. Ali $(\bowtie)$

The Fletcher Network for Sovereign Wealth and Global Capital, The Fletcher School of Law and Diplomacy, Tufts University, Medford, MA, USA 
assets. Following years of exponential growth, the number and size of new SWFs are uncertain, mainly because the key traditional drivers of SWF growth-notably oil price and current account surpluses-have slowed down.

SWFs are emerging in an international environment, and changes in this environment are reflected in the seemingly changing form and function of various SWFs (Clark and Monk 2010). The first generation of SWFs was strongly related to petrodollar flows, with the recycling of oil surpluses into the international financial system and intermediation thereafter of these financial flows via western financial institutions. The emergence of the SWF-mirrored international environment of liberalization of capital accounts and trade and industrialization provided further windfalls from the oil boom. The second generation of SWFs was strongly associated with emerging economies such as BRICS when countries with large trade surpluses started translating sizeable foreign reserves by investing in international equities and alternative financial instruments for attractive financial returns on their investments. The third generation of SWFs, this contribution suggests, are no longer being funded by the proceeds of hydrocarbon exports or export surpluses. Instead, with a focus on socio-economic and development objectives-when economic nationalism is surging and migration, trade, and foreign investment are increasingly becoming contested political issues-developing countries are finding innovative and alternative ways to mobilize foreign capital/aid flows and international financial markets. For example, while Turkey is following the footsteps of earlier examples such as Temask (Singapore) and Kazannah (Malaysia) but with new elements (raising significant amounts of capital on the international market), Bangladesh is trying something quite new, namely, the use of remittances. The possibility of using remittances as a source of funding would bring a number of hitherto non-mentioned countries, such as Armenia, into the SWF debate. However, a more nuanced picture has to be drawn in this emerging category of SWFs to account for varying political, economic, and institutional constraints. The paper is structured as follows: it provides a brief empirical overview on SWFs that were created with non-traditional sources of funding. Then it looks at remittances as a potential funding and revenue stream for creating new SWFs. Thereby it looks at Bangladesh, which discussed in early 2017 the creation of a remittance-funded SWF, and contrasts it with Armenia - a country which is even more dependent on remittance flows. It reveals important nuances that have to be taken into account when creating such a fund. Finally it looks at Turkey's and Indonesia's announced SWFs, which follow the footsteps of a number of well-established older SWFs but have interesting new elements.

\section{Overview}

A recent and increasingly prominent phenomenon in the SWF world relates to the creation of SWFs with development and strategic investment mandates that are designed to leverage and channel foreign direct investments into the domestic 
Table 1 Sovereign development funds

\begin{tabular}{l|l|l|l}
\hline Date est. & SWF name & Country & AUM in bn US\$ \\
\hline 1974 & Temasek & Singapore & 180 \\
\hline 1984 & IPIC & UAE & 58 \\
\hline 1993 & Khazanah Nasional & Malaysia & 34.9 \\
\hline 2002 & Mubadala & UAE & 63.43 \\
\hline \multirow{2}{*}{2006} & Invest. Corp of Dubai & UAE & 196 \\
\cline { 2 - 4 } & Mumtalakat & Bahrain & 11.1 \\
\cline { 2 - 4 } & State Capital Investment Corporation & Vietnam & 1.4 \\
\hline 2007 & CIC & China & 813.76 \\
\hline 2008 & Samruk Kazyna & Kahzakhstan & 49.9 \\
\hline 2017 & Turkish Wealth Fund & Turkey & 200 \\
\hline
\end{tabular}

Source: Sovereign Wealth Center (2017)

economy (Schena and Ali 2016; see Table 1). Some of the most recent examples include the Fondo Strategico Italiano, the Russian Direct Investment Fund, and the Ireland Strategic Investment Fund but the idea of creating such funds is also increasingly gaining momentum in low and lower middle-income countries. Private equity capital seems particularly attractive for countries with underdeveloped public equity markets and shallow debt markets. Sovereign private equity seed funds serve as state-sponsored private equity entities (e.g. Senegal's FONSIS). In 2011 Morocco created Ithmar Capital as a strategic investment fund with the purpose of mobilizing national and international investment into the tourism sector. Financed by the government, Ithmar Captial co-invests in Moroccan projects with other SWFs, and partners with international financial institutions such as the World Bank (Schena and Ali 2016).

Countries with no macroeconomic justifications, such as Senegal or Italy, have already created SWFs. Others, such as Lebanon and Indonesia, are planning to create SWFs. Some of these countries have used government seed funding in the form of capital injections from other government departments or loans to create SWFs (e.g. Senegal, Italy, Panama, France). Others have used asset transfers, such as state enterprise reconfigurations, and merging of existing state investment firms/ funds (e.g. Singapore, Vietnam, Bahrain, Palestine). A number of countries, such as Panama and Luxembourg, have introduced or increased taxes, which then served as a revenue stream for their SWFs. Some countries that could not use the tax instruments for mobilizing funds leveraged their diaspora population for funding, which could then be channeled into a sovereign development fund (e.g., Rwanda). Interestingly, a few economies borrowed funds from the international capital market and re-channeled it into SWFs, which in turn invest in domestic projects (e.g. Ras-al Khaimah, UAE) (Reuters 2017). A thus-far unexplored territory is the study of remittances in the creation of SWFs as a possible funding channel to meet development finance objectives. 


\section{New Sources of Funding and Revenue Streams}

The absence of commodity wealth or current account surpluses is driving many governments away from traditional paths of SWF creation and towards new ways. Such new ways (see Table 2) include leveraging immigrant investor programs,

Table 2 Potential funding and revenue streams

\begin{tabular}{|c|c|c|c|c|}
\hline $\begin{array}{l}\text { New funding and } \\
\text { revenue streams }\end{array}$ & Drivers & Countries & SWFs & $\begin{array}{l}\text { AUM in } \\
\text { bn US\$ }\end{array}$ \\
\hline \multirow[t]{2}{*}{$\begin{array}{l}\text { Intellectual } \\
\text { property rents }\end{array}$} & $\begin{array}{l}\text { Technology, } \\
\text { innovation }\end{array}$ & Japan & IP bridge & $0.1-0.5$ \\
\hline & & France & Brevets & $0.1-0.5$ \\
\hline \multirow[t]{2}{*}{$\begin{array}{l}\text { Government seed } \\
\text { funding }\end{array}$} & $\begin{array}{l}\text { Intergovernmental } \\
\text { transfers }\end{array}$ & Senegal & FONSIS & 1 \\
\hline & & Panama & Fondoahorropanama & 1.39 \\
\hline $\begin{array}{l}\text { Government } \\
\text { borrows on the inter- } \\
\text { national } \\
\text { capital market }\end{array}$ & Low interest rates & UAE & $\begin{array}{l}\text { Ras-al Khaimah } \\
\text { Investment } \\
\text { Authority }\end{array}$ & 1.2 \\
\hline $\begin{array}{l}\text { State asset transfer/ } \\
\text { restructuration }\end{array}$ & & Turkey & $\begin{array}{l}\text { Turkish Wealth } \\
\text { Fund }\end{array}$ & $200^{\mathrm{b}}$ \\
\hline Diaspora funds & Donations & Rwanda & $\begin{array}{l}\text { Agarico } \\
\text { Development Fund }\end{array}$ & 0.039 \\
\hline Remittances & $\begin{array}{l}\text { Migration with } \\
\text { strong linkages to } \\
\text { home countries }\end{array}$ & Bangladesh & Bangladesh SWF & 10 \\
\hline \multirow[t]{2}{*}{$\begin{array}{l}\text { Exchange of } \\
\text { citizenship }\end{array}$} & Migration & Malta & $\begin{array}{l}\text { National } \\
\text { Development and } \\
\text { Social Fund }\end{array}$ & n.a. \\
\hline & & Canada & $\begin{array}{l}\text { Immigrant } \\
\text { Investment Fund }\end{array}$ & n.a. \\
\hline \multirow[t]{2}{*}{ Rare earths } & $\begin{array}{l}\text { Technology, } \\
\text { innovation }^{\mathrm{a}}\end{array}$ & China & n.a. & n.a. \\
\hline & & Russia & n.a. & n.a. \\
\hline Shale gas & Policy and oil price & UK & n.a. & n.a. \\
\hline Commodity tax (coal) & $\begin{array}{l}\text { Policy, } \\
\text { environment }\end{array}$ & India & $\begin{array}{l}\text { National Clean } \\
\text { Environment Fund }\end{array}$ & n.a. \\
\hline \multirow[t]{2}{*}{ Tax revenues } & Electronic VAT & Luxembourg & $\begin{array}{l}\text { Fonds souverain } \\
\text { intergénérationnel } \\
\text { du Luxembourg }\end{array}$ & $1^{\mathrm{b}}$ \\
\hline & $\begin{array}{l}\text { Toll fee (Panama } \\
\text { canal) }\end{array}$ & Panama & Fondoahorropanama & 1.39 \\
\hline
\end{tabular}

Sources: Clarke (2016); Gamlen et al. (2016); Braunstein and Caoili (2016); Braunstein et al. (2016); Atkinson and Hamilton (2016); ClimateChangeNews (2016); Agarico (2018); FONSIS (homepage); Fondoahorropanama (homepage); The Financial Times (07.02.2017); Bloomberg (02.08.2016; 07.02.2017); Ho and Y-Sing (2015); SWFInstitute (2017); Sovereign Wealth Center (2017)

${ }^{a}$ E.g. energy storage technology and high-tech equipment require rare earths

${ }^{\mathrm{b}}$ Projected 
borrowing from international finance institutions, and using the proceeds from special taxes/levies. With regard to the latter, Luxembourg aims to gather at least EUR 50mn per year from e-commerce VAT and a residual part from excise duties, and to reach EUR 1bn over a 20-year period for the 2015-created "wealth fund for intergenerational generations" (Braunstein et al. 2016). This fund was created in order to cover a part of future pension liabilities.

In a similar fashion, the Indian government created the National Clean Environment Fund with revenues from an increase in the coal tax (Climate Change News 2016). In order to increase confidence in the non-fossil fuel sector, the Modi government doubled the carbon tax on coal. The revenue flows into the National Clean Environment Fund, which then invests in clean energy projects (Climate Change News 2016). A consortium consisting of Turkey, Indonesia, and Saudi Arabia, backed by the Jeddah-based Islamic Development Bank, plans to raise financing and underwriting loans for the creation of the Islamic Infrastructure Investment Bank (Vizcaino 2015). In discussing the importance of intellectual property for national development, Clarke (2016) explores the creation of Sovereign Patent Funds (SPFs), which are new applications of SWFs in the global patent market. Once these SPFs are established, governments can support and protect their national champions in terms of litigation and gain additional revenue streams from patent rights. These so-called intellectual rents then become more important in smart societies. Thus far such funds have been mainly created in highly industrialized countries, such as Japan and France, with seed funding from other national finance vehicles (e.g. France's Sovereign Patent Fund was funded by the Caisse de Depot) (Clarke 2016). Similarly, the idea has arisen of leveraging immigrant investor programs (IIPs) - programs that involve the sale of national membership privileges to wealthy foreigners - and using finance capital that was exchanged for residency or citizenship rights to create immigrant investment funds. Structured like SWFs, such funds might be useful tools to invest in critical refugee and migrant infrastructure (Gamlen et al. 2016). An interesting but little-noticed move by a low-income country was made by Rwanda in 2012 when the president launched the Agaciro Development Fund (Agarico 2018). Its funding source also included voluntary donations from Rwanda's diaspora.

Other sources of SWF funding relate to large state enterprises and commodities, such as rare earth or shale gas. Inspired by the well-established oil-funded Norwegian SWF, Atkinson and Hamilton (2016) proposed the creation of a UK SWF, which could be funded by the proceeds from the export of shale gas. According to Atkinson and Hamilton (2016), the UK could have accumulated about GBP 280 billion by 2010 if they had created such a commodity fund in 1975 when they discovered oil in the North Sea. Likewise, the idea of using SWFs as vehicles to transform large SOE sectors is not novel (Kumar 1992). It reaches back to the 1970s when Singapore's government aimed to decrease the SOEs' dependence on the government budget. Singapore's government transferred the stakes of the Ministry of Finance Incorporation into Temasek-Singapore's SWF created in 1974 (Braunstein 2017). It created Temasek as a state-holding company. Whilst improving the fiscal situation, this was also intended to increase efficiency and 
eliminate redundancies through better coordination among SOEs. It could then even raise money on behalf of its companies via the market via issuance of bonds.

The idea of transforming SOEs into large state finance holding companies/SWFs experienced a revival in 2016, when Indonesia's government announced the creation of a US\$320bn SWF which will replace Indonesia's SOE Ministry.

Out of these 13 potential sources, two sources attracted significant attention in 2016 and 2017: SWF capitalization via remittances and SWF creation via stateowned enterprise restructuration. In order to get some more detailed information, the following part explores SWF capitalization via remittances in the pilot cases of Bangladesh and Armenia. Section 4 concludes with an overview of the most recent announcements of SOE restructuring and SWF creation in Turkey and Indonesia.

\section{Remittance Inflows: Challenges and Opportunities}

Migration and global diaspora resources are an integral part of the development process in many developing countries and an important lever of socio-economic development. Remittances refer to personal funding flows from expatriates to their friends and families back home. According to the World Bank Migration and Remittances Factbook 2016, global remittance flows are estimated to have exceeded US $\$ 601 \mathrm{bn}$, of which developing countries are estimated to receive over US $\$ 441 \mathrm{bn}$. Remittances have been a relatively stable source of external financing - more stable than foreign investment or development aid (Worldbank 2003). Around 247 million people, or $3.4 \%$ of the world population, according to the latest World Bank figures, live in a different country from that of their birth.

Interesting patterns of remittance growth can be observed across countries at different income levels. The rise in remittance flows reflects the steady increase in annual labor migration. While average remittance inflows in low-income countries remained low between 2000-2015, upper middle-income countries experienced on average a remittance inflow of US\$3bn in 2015 , up from US $\$ 500 \mathrm{mn}$ in 2000 (calculated with World Bank data 2016). Interestingly, the most dynamic growth in remittance inflows occurred in lower middle-income countries. On average, lower middle-income countries experienced a remittance inflow of more than US\$5trn in 2015, up from approximately US $\$ 700 \mathrm{mn}$ in 2000 (calculated with World Bank data 2016). Many of the lower-middle-income countries, such as Bangladesh, have experienced a dynamic growth in population. At the same time, most of these countries are lacking in social and economic infrastructure.

In many countries at different income levels, remittances constitute a critical part of their respective GDPs. Remittances are often critically important to bolstering foreign exchange reserves and meeting current spending needs. The rationale behind channeling a portion of remittance flows into a sovereign development fund is to insure more efficient management and investment in critical infrastructure (Schena 
and Ali 2016). A key objective or function of such a fund-e.g. FONSIS — would be to catalyze DFI by global investors so as to amplify the impact of local capital.

Remittances as sources of foreign exchange are particularly important for small open economies. For some low-income countries, for example, Nepal and the Comoros, remittances represent more than $25 \%$ of GDP (calculated with World Bank data 2016). For many developing countries, remittances constitute a large part of their FEX inflows and national income. In Tajikistan, for example, remittances represented around 50\% of the GDP in 2013 (calculated with World Bank data 2016). Interestingly, in upper middle-income countries, such as Lebanon, Albania and Bosnia, remittance flows have experienced a continuous decline between 2000 and 2015. In Bosnia and Herzegovina, for example, remittances represented around $10 \%$ of GDP in 2015, down from around 30\% in 2000 (calculated with World Bank data 2016).

Bangladesh and Armenia, too, rely on remittances as part of their budgetary needs but serve as examples of countries with similar remittance levels but with different implications for SWF creation.

\section{Bangladesh}

Bangladesh is a lower middle-income country. Given the myriad of economic challenges, Bangladesh will continue to record budget deficits between the fiscal years 2016/2017 and 2020/2021. The government is facing numerous challenges, ranging from the need to invest in power and water infrastructure to the necessity of raising spending on education and healthcare and reducing poverty to meet the targets of the Sustainable Development Goals (SDGs). The tax collection base remains low and thus the government will continue to struggle with funding, increasing fiscal deficits. For 2016/2017, according to Economic Intelligence Unit (EIU); the government forecasts that progress on widening the tax base will remain slow, weighing on revenue inflows and resulting in a budget deficit of $5.3 \%$ of GDP in that year. The fiscal shortfall will narrow to $4.6 \%$ of GDP by $2020 / 2021$ as the tax base expands, although revenue as a proportion of GDP will average $10.6 \%$ in 2016/2017-2020/2021, one of the lowest levels in Asia (calculated with World Bank data 2016). However, there is hope, in addition to preferential market access to the EU and US markets, that a continuous growth in inflows of worker remittances will compensate for the persistent deficits in the trade, services and primary income accounts, enabling the current account to remain in surplus in 2017-2021.

SWFs were established with one or more objectives, whether to insulate the budget and the economy from excess volatility in revenues; help monetary authorities sterilize unwanted liquidity; build up savings for future generations; or for economic and social development. Bangladesh is one such example of a developing state that is considering deploying a fund for economic and domestic infrastructure development; herein are some ideas for other developing countries, with similar 
socio-economic profiles, that are trying to balance competing budgetary priorities. India, too, just launched an SWF- the National Investment and Infrastructure Fund (NIIF) - with the idea of a national development fund with a focus on natural resource/energy and infrastructural development sectors (Livemint 2016). In the Middle East, countries like Qatar and Kuwait, which suffer from arid land, for example, are strategically deploying their respective SWFs to acquire biotechnology and bio-agricultural technology from European states to manage water and food scarcities. Bahrain is using its fund to harness domestic human capital through a focus on engineering, education, and management sectors.

\section{Purpose of a Bangladeshi SWF: Remittances as a Funding Channel}

In 2015, Bangladesh's central bank chief, Atur Rahman, disclosed that the government is planning to establish an SWF through excess foreign exchange reserves to focus on national infrastructural development projects. In early 2017, the Bangladesh government announced the establishment of a possible \$10bn SWF that would be used for "any purposes in the public interest" (Asia Nikkei 2015). The fund is being floated via sequestering part of the FEX reserves, which had exceeded $\$ 30 \mathrm{bn}$ due primarily to the inflow of steady remittances (Xinhuanet 2017).

Bangladesh is correct to consider innovative options to meet its financial and development needs. With its steady flow of remittances, which in 2016 accounted for $65 \%$ of the country's foreign exchange reserve, Bangladesh is right to invest its reserves for long-term development objectives instead of borrowing or issuing sovereign bonds. According to the central bank of Bangladesh, the remittance inflow for the year 2014-2015 was US $\$ 15.31 \mathrm{bn}$, while the remittance inflow in 2013-2014 was US\$14.23bn—a steady jump from the approx. US\$7.9bn inflow in 2007-2008 (calculated with World Bank data 2016). By contrast, FDI (net inflows) was US \$3.38bn and US\$2.5bn in 2014 and 2013, respectively, according to World Bank data (calculated with World Bank data 2016). The steadily increasing inflow of remittance has to do with the central bank's efforts to facilitate the inflows through formal banking channels. As the structure and mandate of the Bangladeshi SWF are formalized, the creation of an SWF based on excess reserves derived principally via remittance inflows would be a novel idea and one that offers some stylistic lessons for other developing countries. 


\section{Economic and Political Rationale for a Bangladeshi SWF}

A Bangladeshi sovereign development fund capitalized via remittances would be a preferable alternative to foreign aid dependency or favorable trade access to leading markets (subject to the vagaries of the host country's political economic compulsions). Assuming a clearly defined financial-legal and political-economic mandate undergirding such a development fund, a remittance-based SWF provides the necessary funding sources for infrastructural development in a developing country like Bangladesh.

In the case of Bangladesh, an impoverished country with a large migratory labour force working in the Gulf Cooperation Council countries and other parts of the world, remittances are the bread and butter of most Bangladeshi families back home. As indicated earlier, international remittances in Bangladesh in 2015 stood at around $\$ 15 \mathrm{bn}$, covering almost $65 \%$ of the country's foreign exchange reserve for this period (calculated with World Bank data 2016). However, the success of a remittance-based SWF will be contingent upon the government-as the central bank of Bangladesh has been debating - creating a fund that can be sequestered for the broader development of the economy.

Once a remittance-based SWF fund is established, Bangladesh could develop an institutional mechanism to smartly co-invest the proceeds from inflows in national development projects and become less exposed, over time, to the vagaries of international capital and financial markets. Bangladesh is ideally positioned to leverage its strong development cooperation with non-traditional donors such as China, India, Iran, Kuwait, Malaysia, Saudi Arabia, Turkey, and the UAEincidentally, all southern states with SWFs of their own-and deepen its SouthSouth financial-economic engagement. It will also help mitigate sovereign and exchange rate risk as Bangladesh would be channeling its remittance-based SWF into tangible and long-term projects that would yield meaningful socio-economic and financial returns.

\section{Armenia}

Remittances have been the single-most critical external source of capital in Armenia in relative GDP terms, even larger than Bangladesh. Between 2008 and 2015, remittance inflows into Armenia were considerably higher than FDI inflows. As of 2015, about US\$1.6bn in remittances (around 15\% of Armenia's GDP) were sent to Armenia from other countries (calculated with World Bank data 2016). As of 2015, remittances were about the size of Armenia's total export revenues, almost nine times as high as FDI inflows and more than twice as high as portfolio investment inflows. In 2014, remittances were even significantly higher than Armenia's total 
export revenues. With an emigrant remittance stock of 785,740 as of 2015, approximately one-third of Armenia's population works abroad (World Bank, database 2016). On an annual average, each of the emigrants sends about US $\$ 2000$ back to Armenia. This is a considerable amount given the average monthly income in Armenia of US\$350 average in 2015 (Armstat 2017).

Yet the structural features in Armenia show that it is not only the size of remittances that matter for the creation of an SWF but also economic factors. If some remittances are formally allocated to a separate legal structure and invested in long-term projects, they will not qualify as FEX reserves under the IMF's definition. Armenia is extremely exposed to the political and economic vagaries of a single economy-Russia. The generation of remittances is out of the hands of the country, making it particularly vulnerable to sudden stops or decreases in remittance flows. As of 2015, about $60 \%$ of remittance flows to Armenia came from Russia (calculated with World Bank data 2016) so any economic downturn in Russia translates into reduced remittance inflows or remittance supply shocks in Armenia, leading to a decline in FEX reserves. This would leave the central bank and the Armenian currency vulnerable and encourage raiding the fund to backfill reserves (e.g., similar to what happened in Azerbaijan). Hence, Armenia's economy is closely linked to the business cycles of the Russian economy, which is a major reason why remittancerelated reserves are kept in the central bank.

Another promising route for SWF creation among many countries relates to the restructuration process of state-owned enterprise sectors. Countries with large SOE sectors, in particular, which do not want to privatize their SOEs, might choose the SWF route. This follows earlier models of state-holding companies-where governments try to separate ownership and management functions in order to permit the companies greater operational freedom from the state - combined with modern elements of attracting foreign capital via the issuance of bonds or for co-investments (Kumar 1992, Wall Street Journal, 17.02.2017).

\section{Capitalizing a Fund Through Restructuring State-Owned Enterprises (SOEs): Cases of Indonesia and Turkey}

Indonesia's announcement that it was creating an SWF in May 2016 was followed in February 2017 by Turkey's statement that it was creating a Turkish Wealth Fund. Turkey and Indonesia are following in Singapore's footsteps. It was in the early 1970s when the government of Singapore made the first move by transferring the stakes of the Ministry of Finance Incorporation into Temasek Holding-Singapore's SWF created in 1974. Singapore's other ministries followed suit by transferring their assets into similar holdings, such as the Sheng-Li Holding (defense-related industries) and the Ministry of National Development Holding (housing development and land corporations). Then, in the early 1980s, most of the assets were merged into Temasek's portfolio (Braunstein 2017). 
Indonesia's new SWF will be modeled after Malaysia's Khazannah Nasional and will reportedly control US\$320bn worth of assets by 2019 (Bloomberg, 17 May 2016). To accelerate the process, the government plans to create four sector-specific sub-holdings, starting with the energy sector (Braunstein and Caoili 2016) The new SWF will replace Indonesia's SOE ministry and act as the parent for 199 of the largest SOEs. In a similar fashion, the Turkish government announced the transfer of government stakes in a number of high-profile companies, such as Turkish Airlines, a Turkish oil company, Halkbank, and Turk Telekom, into an SWF (The Financial Times, 07.02.2017). The size of a Turkish SWF could reach US\$200bn (Bloomberg, 07.02.2017).

The creation of the Turkish Wealth Fund and the announcement of an Indonesian SWF reflect the latest developments in the evolution of SWFs created with the proceeds of large-scale state-owned enterprise restructuration. The rationale behind divesting state assets and putting the proceeds into an SWF is driven-partly at least-by the consideration to leverage national assets to raise money on the international capital market. Unlike earlier SWFs, notably Temasek, which issue bonds to get a rating and increase transparency, Turkey aims to raise money via its SWF on the international market for a number of high-profile infrastructure projects (The Financial Times, 07.02.2017). In the case of Indonesia, the aim of restructuring the SOE sector via the creation of an SWF is to decrease the SOEs' dependence on the government budget. While improving the fiscal situation, this should also increase efficiency and eliminate redundancies through better coordination among SOEs (Braunstein and Caoili 2016). In an age of increasing budget deficits and the need to reform large SOE sectors, other potential candidates for SWFs might also follow suit, including Pakistan and Iran.

\section{Conclusion}

The recent proliferation of SWFs among countries with no macroeconomic justification should not be surprising given their pledge of supporting national development agendas.

SWFs increasingly serve as an important dimension of the domestic political imperatives and economic policy considerations (i.e., economic diversification, economic development, macroeconomic stability) in the sponsoring states. This is reflected in their mandates, which have grown beyond their initial functions of stabilizing budgets and saving for future generations-via international portfolio investments - to include objectives related to domestic development purposes. These funds are increasingly integrated into the overall economic development strategy of the countries and can help generate long-term economic value and sustainability.

This contribution highlights - through four representative examples (Bangladesh, Armenia, Indonesia, and Turkey) - the need for more in-depth research into new frontiers in sovereign wealth fund capitalization in order to understand novel forms 
of state-driven financial engineering. Academics and policy makers are confronted with a new set of questions: What do these innovations mean for long and wellestablished SWFs, as well as their underlying theories? Recent examples of SWF formation show that the creation of such new SWFs not only depends on the availability of budget-, commodity-, and FEX surpluses. New capitalization channels are identified for creating SWFs, allowing governments without surpluses to create SWFs in order to leverage international capital for domestic policy purposes. What is the role of emulation and policy learning in the adaptation of these new forms of investment institutions? Does financial engineering in the SWF area occur on a continuum from less disruptive to radical innovation of institutions? If yes, what are the implications and unintended consequences?

For practitioners and scholars, financial engineering in the SWF arena offers the opportunity to identify creative ways of leveraging national assets and linking them to domestic and regional development agendas. Given the myriad socio-economic challenges facing these developing countries (water, electricity, population bulge, dilapidated infrastructure), sequestering a portion of revenues-derived via remittances or FDIs or exports-in a financial vehicle that could be deployed strategically for national economic development projects should be a national priority. However, this would tie significant amounts of FEX into long-term projects, which could become a problem in countries that have high exposure to single markets that are highly volatile.

A combination of increasing budgetary constraints and increasing domestic demand for basic services/infrastructure put increasing pressure on governments with large SOE sectors towards financial innovation. Here, financial engineering is about finding organizational formats that allow the leverage of existing national assets for the purpose of financing public goods and basic infrastructure services. SWFs will play an increasingly prominent role and as such they are expected to continue growing. However, establishing a depoliticized institutional mechanism for the management of such a fund would be a monumental task - as seen when the rentier proclivities of the ruling elite drained Nigerian and Libyan funds-for developing countries like Bangladesh. Many other countries with such fundsfrom liberal democracies (Norway Oil Fund) to the Gulf States (Qatar, Kuwait, UAE) to Southeast Asian countries (Malaysia, South Korea, China) to countries in Africa (Ghana) - among others - offer some successful lessons in how to deploy a national wealth fund.

\section{References}

Agarico. (2018). Overview. Accessed January 1, 2018, from http://www.agaciro.rw/index.php? $\mathrm{id}=34$

Armstat. (2017). Armenia statistics [homepage]. Accessed May 2, 2017, from http://www.armstat. $\mathrm{am} / \mathrm{en} / \mathrm{nid}=126 \& \mathrm{id}=0800>1$ 
Asia Nikkei. (2015, August 3). Bangladesh to launch sovereign wealth fund. Accessed September 3, 2016, from http://asia.nikkei.com/Politics-Economy/Economy/Bangladesh-to-launch-sover eign-wealth-fund-central-bank-chief

Atkinson, G., \& Hamilton, K. (2016). Asset accounting, fiscal policy and the UK's oil and gas resources, past and future (Working paper no. 250). Grantham Research Institute on Climate Change and the Environment, pp. 1-27.

Braunstein, J. (2017). The domestic drivers of state finance institutions: Evidence from sovereign wealth funds. Review of International Political Economy, 24(6), 980-1003.

Braunstein, J. (2018). Domestic sources of twenty-first-century geopolitics: Domestic politics and sovereign wealth funds in GCC economies. New Political Economy, 1-21.

Braunstein, J., \& Caoili A. (2016). Indonesia: The vanguard of a new wave of sovereign wealth funds? LSE government blog. Accessed September 2, 2017, from http://blogs.lse.ac.uk/govern ment/2016/08/30/indonesia-the-vanguard-of-a-new-wave-of-sovereign-wealth-funds/

Braunstein, J., Laboure, M., \& Sen, J. (2016). Windfall revenues in Europe: What's next? LSE euro crisis in the press blog. Accessed May 2, 2017, from http://blogs.lse.ac.uk/eurocrisispress/2016/ 12/16/windfall-revenues-in-europe-whats-next/

Clark, G., \& Monk, A. (2010). Sovereign wealth funds: Form and function in the 21 st century (Working paper).

Clarke, W. (2016). Sovereign patent funds: Sovereign wealth funds 2.0? Global Policy, 7(4), 577-583.

Climate Change News. (2016). Will doubling indias coal tax boos the clean energy sector? Accessed April 1, 2016, from http://www.climatechangenews.com/2016/04/01/will-doublingindias-coal-tax-boost-the-clean-energy-sector/

Gamlen, A., Kutarna, C., \& Monk, A. H. B. (2016). Re-thinking immigrant investment funds (Working paper no. 128). Oxford: University of Oxford.

Ho, Y., \& Y-Sing, L. (2015). Indonesia seeks stature by hosting islamic development bank unit. Bloomberg. Accessed April 15, 2015, from https://www.bloomberg.com/news/articles/201504-15/indonesia-seeks-stature-by-hosting-islamic-development-bank-unit

Kumar, A. (1992). The state holding company: Issues and options (pp. 1-67). World Bank WDP187.

Livemint. (2016, July 15). India's sovereign wealth fund identifies first eight projects for investments. Accessed March 2, 2017, from http://www.livemint.com/Companies/ II3QqngchIvMdQ4skDqijN/Indias-sovereign-wealth-fund-identifies-first-eight-project.html

Reuters. (2017, February 9). Emirate of Ras Al Khaimah in talks with banks for dollar bond. Accessed February 10, 2017, from http://www.reuters.com/article/ras-al-khaimah-bondidUSL5N1FU3YI

Schena, P., \& Ali, A. (2016). Sovereign wealth fund investment in economic transformation: Toward an institutional framework (Working paper). Investment Funds for Development, Community of Practice World Bank.

Schena, P. J., Braunstein, J., \& Ali, A. (2018). The case for economic development through sovereign investment: A paradox of scarcity? Global Policy, 9(3), 365-376.

Sovereign Wealth Center. (2017). SWF rankings (homepage). Accessed December 15, 2017, from http://www.sovereignwealthcenter.com/

SWFInstitute. (2017). SWF ranking (homepage). Accessed September 1, 2017, from https://www. swfinstitute.org/

Vizcaino, B. (2015). Saudi Arabia to join Turkey, Indonesia in infrastructure Islamic Bank. Reuters. Accessed May 23, 2016, from http://www.reuters.com/article/us-islamic-financesaudi-idUSKCNOYEOU1

World Bank. (2003). Workers' remittances: An important and stable source of external development finance. Accessed May 2, 2016, from http://siteresources.worldbank.org/INTRGDF/ Resources/GDF2003-Chapter7.pdf 
Xinhuanet. (2017). Bangladesh cabinet approves proposal to set up sovereign wealth fund. Accessed February 6, 2016, from http://news.xinhuanet.com/english/2017-02/06/c _ 136035956.htm

Open Access This chapter is licensed under the terms of the Creative Commons Attribution 4.0 International License (http://creativecommons.org/licenses/by/4.0/), which permits use, sharing, adaptation, distribution and reproduction in any medium or format, as long as you give appropriate credit to the original author(s) and the source, provide a link to the Creative Commons licence and indicate if changes were made.

The images or other third party material in this chapter are included in the chapter's Creative Commons licence, unless indicated otherwise in a credit line to the material. If material is not included in the chapter's Creative Commons licence and your intended use is not permitted by statutory regulation or exceeds the permitted use, you will need to obtain permission directly from the copyright holder. 


\title{
The Impact of Macroeconomic Factors on FDI Attractiveness: Romania, Slovakia and Greece in Comparison
}

\author{
Kalliopi Kasapi, Andriana Lampou, George Economakis, \\ George Androulakis, and Ioannis Zisimopoulos
}

\section{Introduction}

The aim of this contribution is to investigate the key macroeconomic factors that may affect inward FDI in rather small European economies, such as Romania, Slovakia and Greece, which are all at a different level in their process of European integration. Romania and Slovakia are both economies in transition. Romania is a member of the EU but still not a member of the EMU while Slovakia and Greece are both members of the EU and the EMU.

The main macroeconomic factors evaluated are inward FDI, GDP growth, real unit labor costs (ULC), trade balance, exchange rate, sectoral distribution of exports, and economic complexity.

\section{Theoretical Frameword}

FDI can contribute to an economy's growth through being a source of capital formation and through technology transfer, "externalities" or "spillover effects" (Fan and Dickie 2000, p. 314) and GDP growth deriving from the improvement of the host country's trade balance. This contribution focuses on the latter.

\footnotetext{
K. Kasapi $(\bowtie) \cdot$ A. Lampou $(\bowtie) \cdot$ G. Economakis $(\bowtie) \cdot$ G. Androulakis $(\bowtie) \cdot$

I. Zisimopoulos $(\square)$

University of Patras, Patras, Greece

e-mail: economak@upatras.gr; gandroul@upatras.gr 


\subsection{Main FDI Categories}

The following FDI categories can be distinguished according to their effect on the host country's trade balance.

1. FDI for producing goods for the domestic market that could operate either as a substitute for investors' exports or equivalently for the host country's imports ("market-seeking” FDI) (Iammarino and Pitelis 1999, pp. 4-5; Lim 2001, pp. 11-12).

This FDI category includes "market-oriented theories for FDI" (Busch 1992, pp. 201-208). It is argued that market-seeking FDI could replace the imports of products of the host country (Iammarino and Pitelis 1999, p. 4; Busch 1992, p. 204; Lim 2001, p. 11) and therefore, ceteris paribus, an improvement of its trade balance is expected. The main incentives of this FDI category are related to the reduction of costs necessary for supplying the domestic market (and thus to increased capital profitability); these costs come from the imposition of duties on the imported goods (Lim 2001, p. 11), national currency devaluation (Busch 1992, pp. 204-205), or from transport costs (Busch 1992, p. 202; Lim 2001, p. 11). Economic growth, as it is expressed by GDP growth, is an indicator of an augmenting domestic market and may explain the increase of marketseeking FDI.

2. FDI for producing goods for the global market (Giannitsis 1983, pp. 300-355; Milios and Ioakeimoglou 1990, pp. 158-159; Iammarino and Pitelis 1999, pp. 4-5; Lim 2001, pp. 11-12; Economakis et al. 2005).

This FDI category includes the "cost-oriented theories for FDI" or the "theories of mobility/allocation of production for cost reasons" (Busch 1992, pp. 201-208). FDI is connected to the "decentralization of stages of production" (Iammarino and Pitelis 1999, p. 4) and the "relocation of the chain in a low-cost location" (Lim 2001, p. 11). The main incentives of this FDI category are related to the reduction of production costs for supplying the global market, such as the reduction of labor costs and the costs of raw materials as well as the opportunity to access to certain "externalities" (e.g. "cluster of FDI in one location", which is referred as "agglomeration") (Lim 2001, p. 11). The transport costs and the proximity of the markets to which the investor's products are exported should be taken under consideration (Economakis et al. 2005) while the market size of the host country does not seem to play a key role (Lim 2001, pp. 11-12). This FDI category is, ceteris paribus, positively related to the improvement of the host country's trade balance since FDI tends to increase the host country exports.

It must be noted that FDI of the first category could be interconnected with the FDI of the second category as inputs that reinforce the export-oriented FDI.

However, the increasing FDI of both categories may cause an increase of imports due to the export orientation of foreign industries in the supply of intermediate inputs, especially if the sectors in which foreign investment activity is concentrated are weakly interconnected with other sectors of the host economy (Giannitsis 1983, p. 353). 
3. FDI that facilitates the foreign investor's imports (Iammarino and Pitelis 1999, pp. 4-5; Lankes and Venables 1996), which is negatively related to the host country's trade balance, or FDI for establishing commercial distribution networks through which domestic products are exported to global markets, which could improve the host country's trade balance.

4. FDI for domestic production in non-tradable goods and services sectors ${ }^{1}$ that are directed to the host country's domestic market (such as the first FDI category). This FDI category does not replace the investor country's exports and it is not directly related to the host country's trade balance.

5. FDI directed to financial intermediation which is not connected directly to the production or to the commercial sphere (Tsantilas 2009, p. 19) but aims to exploit investment opportunities within the host country and has an ambiguous impact on the host country's trade balance.

The following analysis is restricted to the investigation of FDI of the first and second categories.

\subsection{FDI and Economic Complexity}

Economic complexity, which depicts the level of economic development, may influence inward FDI. Economic complexity is "a measure of the knowledge in a society as expressed in the products it makes and is calculated based on the diversity of a country's goods exports and their ubiquity, or the number of the countries able to produce them" and it is measured by the Economic Complexity Index (ECI) (Atlas of Economic Complexity)". "Complex economies are those that can weave vast quantities of relevant knowledge together, across large networks of people, to generate a diverse mix of knowledge-intensive products. Simpler economies, in contrast, have a narrow base of productive knowledge and produce fewer and simpler products which require smaller webs of interaction" (Hausmann et al. 2011). Since "webs of interaction" is another name for "externalities", "complex economies" are, ceteris paribus, attractive destinations for FDI, especially those directed to high-tech sectors.

\section{FDI in the Context of European Integration}

The incentives of the first two FDI categories will be assessed considering their possible positive effect on the host country's trade balance. The imposition of duties, the devaluation of national currency, the geographic position of the country, and

\footnotetext{
${ }^{1}$ Electricity, construction, transportation and storage services, telecommunication services, wholesale and retail trade, and other services (Gibson 2010, p. 340).
} 
GDP growth will be evaluated according to their effect on FDI of the first category. Moreover, the ULC and the proximity of markets will be evaluated according to their effect on FDI of the second category.

\subsection{The Case of Romania}

\subsubsection{Market-Seeking FDI: Tariffs, GDP, and National Currency}

As it can be seen from Fig. 1 Romania's FDI stock as a percentage of the world total (FDI-w.t.percentage) had an upward trend until 2008. In 2008, 1 year after Romania's accession to the EU, the country attracted a record amount of FDI. Between the years 2000 and 2008, large multinational companies invested in the country, while between 2003 and 2005, Romania received the highest rates of FDI inflows in Eastern Europe (Andrei 2014). However, after 2008, the relative position of the country as a receiver of FDI deteriorated significantly, since FDI stock in Romania diminished from $0.42 \%$ of the world total in 2008 to $0.27 \%$ in 2016 (UNCTAD).

Romania embarked on its journey towards EU membership in 1993 with the signing of the Europe Agreement, whose purpose was to prepare the country for accession to the EU (1995-2005). The Agreement was asymmetric in nature, with the EU willing to eliminate its trade barriers for Romanian exports over the first half of the period and Romania doing the same for EU exports over the second half. This concession given by the EU together with the preferential fiscal regime for Romanian exporters brought results in terms of a solid increase in Romanian exports

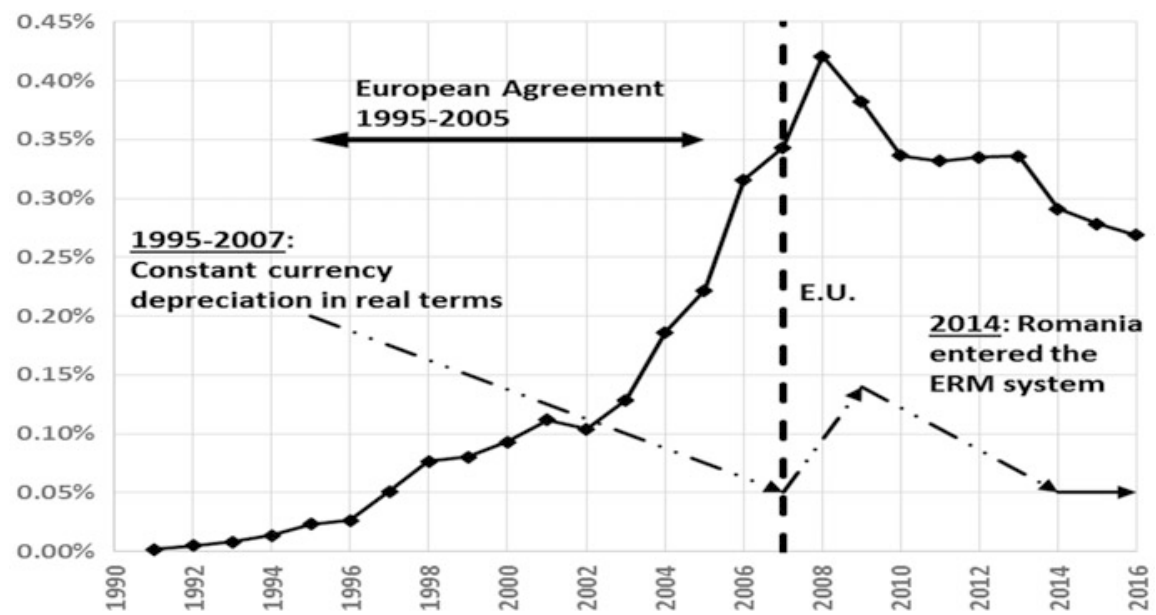

Fig. 1 FDI stock of Romania (\% of total world), 1991-2016. Source: UNCTAD \& IMF 
(Marinescu and Szeles 2010). After 1995 the phasing out of tariffs began, a course necessary before the country's accession to the EU. Taking into account the high dependence on Romania's FDI coming from the EU members (NBR), a negative effect on attracting FDI of the first category would be expected. However, FDI was not affected negatively by the tariffs phasing out, which continued to increase during the same period. The same does not apply after the country accession to the EU in 2007.

Another incentive for attracting market-seeking FDI is the country's national currency exchange rate. Between the years 1995 and 2008, FDI in Romania had an upward trend and the currency showed a trend of devaluation in real terms (IMF). Part of the increase of FDI could be explained by the devaluation of the Romanian national currency, i.e. FDI in order to circumvent the exchange rate protection. Therefore, although the incentive to circumvent tariff protectionism for attracting FDI has faded out, the incentive to circumvent the exchange rate protection remains for foreign firms.

A rising GDP could be another possible incentive for attracting FDI. Romania's FDI-w.t.percentage and GDP increased almost simultaneously between the years 1994 and 2008, decreased between 2008 and 2009, and after 2009 they disconnected (AMECO). The two variables have a weak positive relationship $(\rho=0.44)$ between the years 1994 and 2016. Romania's FDI and GDP common rising trend until 2008 probably indicates that the market size is related to the increased FDI. However, after 2009, FDI and GDP disconnect, indicating that market size changes don't affect market-seeking FDI.

The geographical distance between the investor's country and the host country and the transportation costs don't seem to play a significant role in attracting marketseeking FDI since Romania's main investors (NBR) and trade partners are nearby countries of the EU (UNCTAD).

\subsubsection{Export-Oriented FDI: Wage-Productivity Relationship and Geographic Proximity}

Romania's ULC constantly decreased between the years 1990 and 2016 (AMECO). This downward trend could explain, to some extent, the increase of FDI inflows over the same period. However, the same factor does not seem to be strong enough to reverse the decline of FDI in the Romanian economy after 2008. The strong negative correlation of FDI-w.t.percentage and ULC between the years 1990 and 2016 ( $\rho=-0.76)$ means that the level of ULC may influence the level of export-oriented FDI attracted by Romania.

The geographic proximity of Romania with the other EU counties, which are its main investors, could also be an incentive for export-oriented FDI. 


\subsubsection{FDI and Trade Balance of Romania}

Figure 2 depicts Romania's FDI-w.t.percentage as well as the rate of coverage of imports (M) by exports (X) of goods (exports/imports).

Between the years 1994 and 2008, Romanian FDI constantly increased while the trade balance deteriorated. On the contrary, after 2009, the Romanian trade balance improved despite the downturn of FDI, which indicates that FDI is strongly negatively related to external trade. FDI-w.t.percentage and X/M have a strong negative relationship between the years 1994 and $2016(\rho=-0.96)$, indicating a disconnection between FDI and external trade.

In an attempt for further analysis, exports and FDI-w.t.percentage have a strong positive correlation $(\rho=0.77)$ between the years 1994 and 2016, which could indicate the presence of export-oriented FDI. Imports and FDI-w.t.percentage have a strong positive correlation $(\rho=0.87)$ for the same period. Romanian FDI inflows don't seem to have significantly replaced imports. Nevertheless, the increase of imports could be partly explained as a result of FDI inflows in Romania since FDI can create import-demands necessary for the production process. The trade balance improved after 2009, which could be related to the current account crisis of the Romanian economy and the implementation of restrictive policy measures that led to an import decrease and an improved trade balance (Economakis et al. 2016).

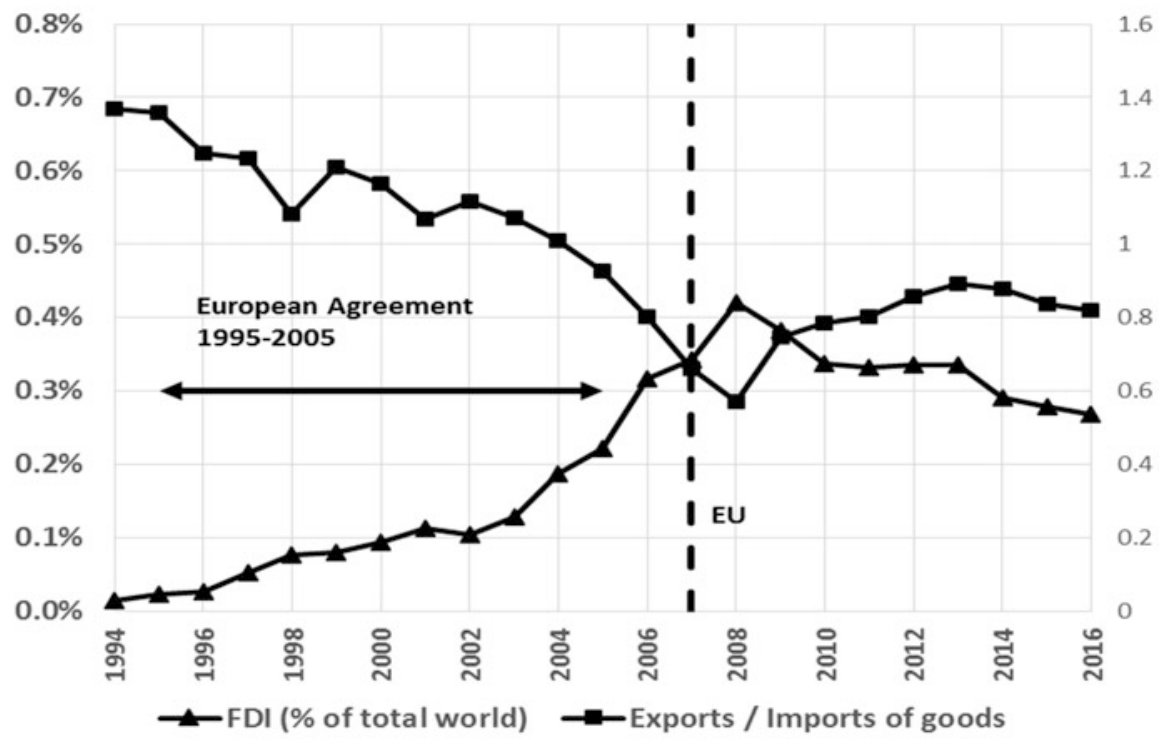

Fig. 2 FDI stock (\% total world) and exports/imports of goods of Romania (1994-2016). Source: UNCTAD \& AMECO 
Summarizing, the received FDI of the first and second category were not strong enough to significantly affect the trade balance, throughout the period examined, despite the presence of FDI of the second category. FDI in Romania is mostly attracted by non-tradable sectors or sectors that are not connected to external trade. In 2004 the service sector was absorbing $46 \%$ and the industry sector $54 \%$ of the total FDI received by Romania while in 2016 the service sector absorbed $55 \%$ and the industry sector 45\% (NBR, Annual reports 2004-2016). This confirms that an important part of FDI is attracted by non-tradable sectors (trade, telecommunications) or sectors with an unclear impact on trade balance (financial intermediation, real estate). In 2007 financial intermediation absorbed $23 \%$ and trade $14 \%$ of the total FDI received by the country (NBR, Annual reports 2004-2016).

\subsubsection{Romania's FDI Positions by Industry \& Exports and Imports Structure}

Figure 3 depicts the distribution of Romanian FDI by industry between 2004 and 2016 (NBR, Annual reports 2004-2016). By comparing the distribution of Romanian FDI by industry with the distribution of the country's imports and exports some conclusions can be derived about the FDI category received. The composition of Romanian exports has changed over time. Textiles and clothing represented the major export products (about one-fourth of all exports) but they lost their top spot after 2003. More specifically, the exports of the industry decreased from $27 \%$ of

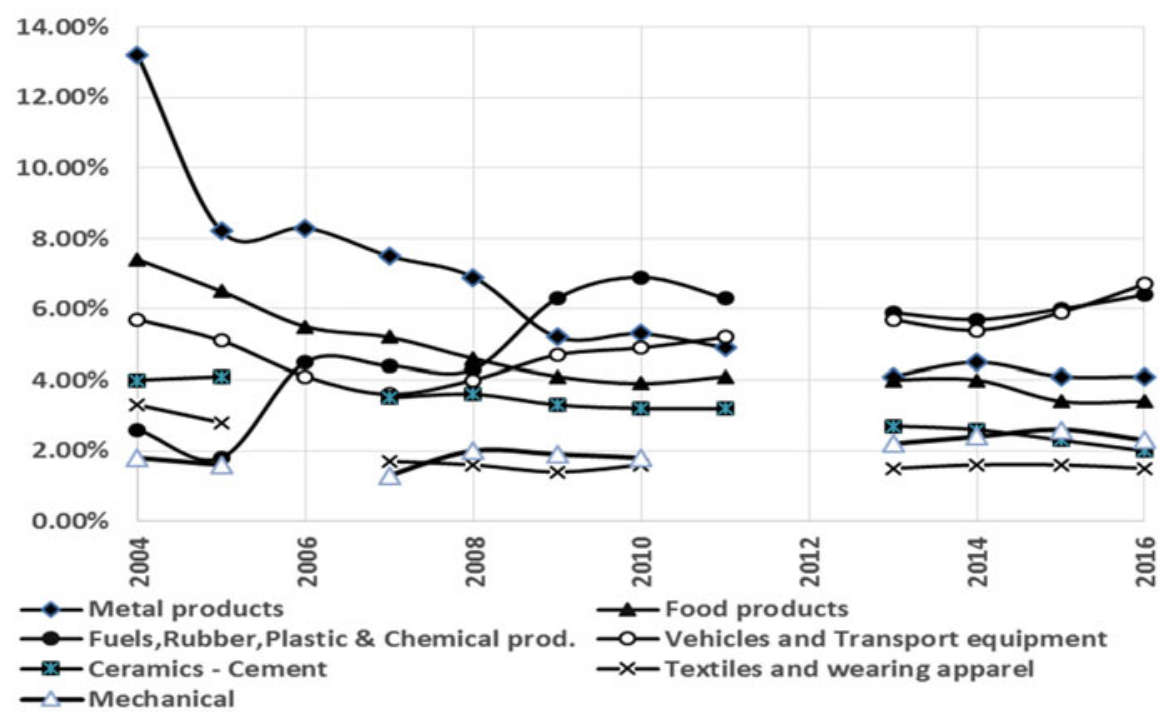

Fig. 3 FDI distribution by industry (2004-2016), (\% of total FDI positions of Romania). Source: NBR 
the total Romanian exports in 2007 to $7 \%$ in 2016, while the industry's imports decreased to $7 \%$ of the total imports in 2016 from 19\% in 1997 (UNCTAD). The textile industry has also experienced a decline in FDI, which suggests that the industry is generally unattractive; it also indicates disinvestment. Since there is a major decline in the exports, imports, and FDI of textile products, there is evidence that the FDI attracted could be of the second category.

There is also a significant increase in the Romanian export of vehicles and transport equipment, which seems to be directly related to the FDI attracted in this sector, especially after Renault acquired the Romanian automaker Dacia in 1999 and Ford Motor Co. made major investments in Romania in 2008 (Marinescu and Szeles 2010). Moreover, the industry's export increased from 5\% of the total exports in 1999 to $17 \%$ in 2016 (UNCTAD). FDI also increased, reaching $6.7 \%$ of the total FDI in 2016 (NBR, Annual reports 2004-2016), indicating that the FDI attracted is mainly of the second category.

There is also a major development of exports of mechanical products, mainly triggered by automotive parts and components. Romania's strong presence in the automotive industry is illustrated by the fact that "there is virtually no car producer in Europe that does not use spare parts produced in Romania, in other words, the assembly lines in Europe are supported by exports of Romania" (Dobreanu 2014). The exports of mechanical products increased from 9\% of the total exports in 1995 to $29 \%$ in 2016, while the imports of the industry also increased from $21 \%$ in 1991 to $27 \%$ in 2016 (UNCTAD). Thus, there is evidence that the increasing exports came with an increasing import-demand, such as inputs for the production process. Therefore, the FDI attracted by Romania in the sector could be possibly exportdriven (second category).

In the case of the food industry, FDI dropped, exports increased, and imports stayed relatively stable throughout the period examined, indicating that the declining FDI was probably of the first category.

Other sectors in which the FDI in the Romanian economy seem to be of the first category are the fuel industry and the cement-ceramics industry. In both cases, FDI increased while exports and imports decreased.

In the metal products industry, FDI and exports decreased but imports slightly increased. More specifically, the exports of metal products decreased from $15 \%$ of total Romanian exports in 1995 to $6 \%$ in 2016 while the imports of these products increased from 5\% in 1995 to $7 \%$ in 2016 of the total imports (UNCTAD). This could mean that these products were export-oriented and the FDI attracted was of the second category. Therefore, a downtrend in FDI led to a decrease of exports. Additionally, metal products could be significant inflows for other industries, such as mechanical products and vehicles, whose exports increased, and some of the FDI could be an intermediate category of FDI between the first and the second.

Therefore, Romanian FDI in the manufacturing industry between the years 2004 and 2016 is both market-seeking (first category) and export-oriented (second category). 


\subsection{The Case of Slovakia}

\subsubsection{Market-Seeking FDI: Tariffs, GDP, And National Currency}

As it can be seen from Fig. 4, Slovakia's FDI-w.t.percentage had an upward trend until 2008. After Slovakia's accession to the EU in 2004 and until 2008, FDI stock increased but at a decreasing pace. After 2008, 1 year before the country's accession to the EMU, Slovakia's FDI stock started to decrease. The relative position of the country as a receiver of FDI deteriorated since FDI stock in Slovakia diminished from $0.33 \%$ of the world total in 2008 to $0.16 \%$ in 2016 (UNCTAD).

In 1994, the application of high tariffs on imports (WTO 1995) was an incentive for attracting FDI of the first category in order to overcome the costs that resulted from the imposition of duties on the imported goods. The country started to phase out tariffs in 1995, a course necessary before the country's accession to the EU (Slovak Republic.org n.d.). This process was carried out by a number of agreements (EEFTA, EFTA, EEA). In 2004 Slovakia continued its course to a free market economy by accessing the EU, which did not negatively affect FDI attraction. Taking into account the high dependence on Slovakia's FDI coming from the EU members (OECD), a negative effect on attracting FDI of the first category would be expected. However, this fact did not influence the FDI attracted, which continued to increase.

Between 1993 and 2009, Slovakia's national currency depreciated in real terms (IMF), which was an incentive for attracting FDI of the first category in order to bypass exchange rate barriers and may explain, to some extent, the increased FDI.

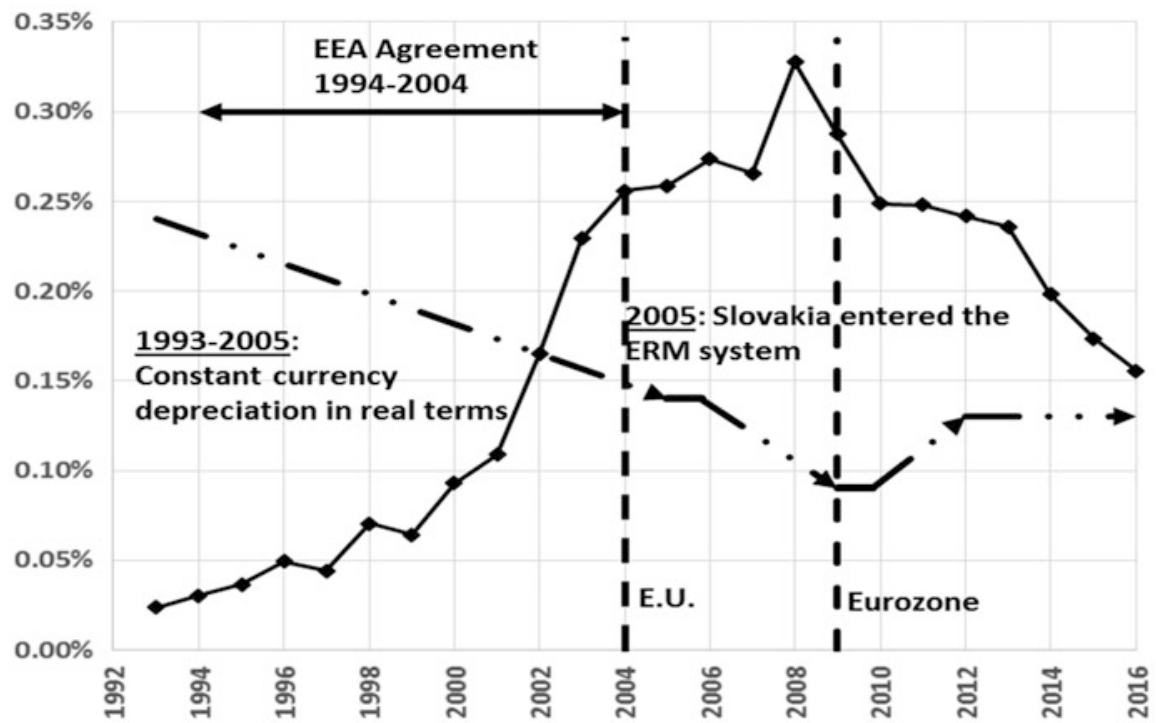

Fig. 4 FDI stock of Slovakia (\% of total world), 1993-2016. Source: UNCTAD \& IMF 
Therefore, although the incentive to circumvent tariff protectionism for attracting FDI had faded, the incentive to circumvent the exchange rate protection remained for foreign firms until 2009. After 2009, Slovakia accessed the EMU and there is no national currency under which FDI inflows can be explained, while FDI decreased considerably.

The geographical distance between the investor's country and the host country, as well as the transportation costs, don't seem to benefit the FDI of the first category since Slovakia's main investors (OECD) and trade partners (UNCTAD) are nearby countries of the EU.

Moreover, both GDP and FDI-w.t.percentage increased between the years 1994 and 2008 (AMECO). The two variables have a strong positive relationship ( $\rho=0.82$ ) between 1994 and 2016, which indicates that the growth of the Slovakian economy is positively related to market-seeking FDI. However, this is confirmed until 2009 since after that year the two variables seemed to disconnect.

\subsubsection{Export-Oriented FDI: Wage-Productivity Relationship and Geographic Proximity}

There was a decrease in Slovakia's ULC between the years 1997 and 2008 (AMECO), which could theoretically explain, to some extent, the increase of FDI. However, between the years 2008 and 2016, ULC increased. The weak negative correlation $(\rho=-0.52)$ between FDI-w.t.percentage and the ULC for the period 1995-2016 means that the cost competitiveness of Slovakia's economy has a weak relationship with the attraction of FDI.

An advantage of Slovakia, as a host country of FDI of the second category, is its geographical location. According to the three major car industries invested in the country, Slovakia was selected mostly because of its geographical location, great infrastructure, proximity to EU member states and growing economy in comparison with another member of V4 (Bratscht 2012, pp. 10-16).

\subsubsection{FDI and Trade Balance of Slovakia}

As can be seen from Fig. 5, Slovakian trade balance improves with some fluctuations after 1998. Slovakia's FDI-w.t.percentage has an upward trend until 2008 and the country's trade balance improves simultaneously. After 2008, Slovakia's trade balance continuous to improve while FDI-w.t.percentage starts to decrease. In particular, Slovakia has a trade surplus after 2009, while FDI falls significantly. FDI-w.t.percentage and X/M have a weak positive relationship $(\rho=0.56)$ between the years 1994 and 2016, which means that FDI is connected only to some extent to the external trade.

Moreover, Slovakia's trade balance continuous to improve after the country's accession to both the EU and the EMU. Nevertheless, after the country's accession to the EMU, X/M and FDI follow opposite directions. 


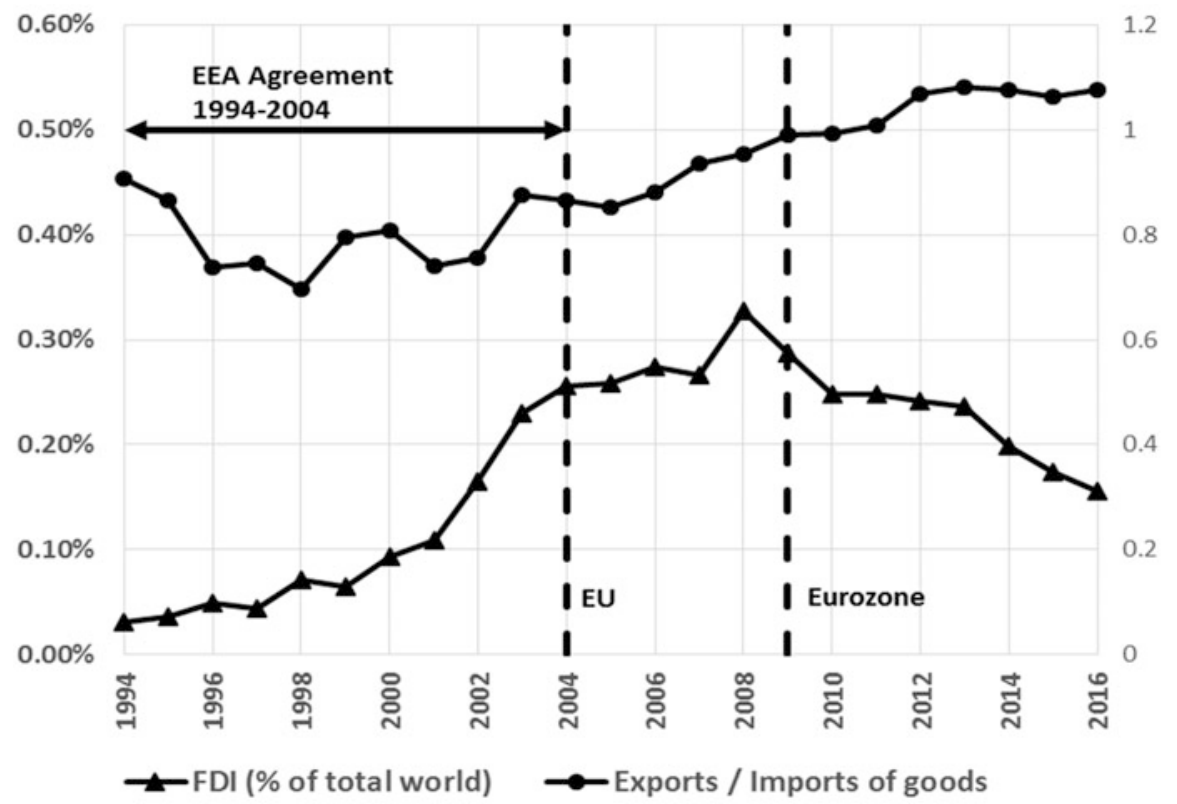

Fig. 5 FDI stock (\% total world) and exports/imports of goods of Slovakia (1994-2016). Source: UNCTAD \& AMECO

The relationship between exports and FDI-w.t.percentage has a positive correlation $(\rho=0.64)$ between 1994-2016, indicating the probable presence of FDI of the second category. The relationship between imports and FDI-w.t.percentage was strong and positive $(\rho=0.70)$ between the years 1994 and 2016. As in the case of Romania, the increase of Slovakian imports could be partly explained as a result of import-demands necessary for the production process created by increased FDI. In any case, Slovakia's FDI (like Romania's) doesn't seem to have significantly substituted imports.

Given the above, the trade surplus after 2009 cannot be attributed to the rising FDI of the first or second category, despite the evidence about the presence of FDI of the second category for the whole period examined. Between the years 1998 and 2003, FDI attracted by the service sector is higher than FDI attracted by the industrial sector absorbing about 55\% and 36\% of FDI, respectively. After 2004 and until 2007, FDI in the industrial sector accounted for almost $50 \%$ of the Slovakian FDI, more than the service sector, while during the same period Slovakia's trade balance was improving (OECD). The high increase of FDI-w.t.percentage between 2002 and 2004 is related with the establishment of the two car industries, Peugeot and KIA (Bratscht 2012, pp. 10-16). However, after 2009, FDI inflows in Slovakia are again mostly attracted by service sector, which absorbed approximately the $50 \%$ of Slovakia's FDI and in particular by non-tradable sectors or sectors that are not directly connected to external trade and have unknown impact to the trade balance. 
Thus, to the extent of any influence of FDI on trade balance, the improved trade balance, despite the decline of FDI after 2008, could only be due to the positive effect of earlier FDI, especially the one of the second category.

\subsubsection{Slovakia's FDI Positions by Industry \& Exports and Imports Structure}

As it can be seen from Fig. 6, the automotive industry is a leading sector of FDI attracted by Slovakia. In particular, three major car industries invested in the country: Volkswagen Slovakia, KIA Motors and PSA Peugeot Citroen (Bratscht 2012, pp. 10-16). Volkswagen Slovakia was founded in 1991, while the other two companies invested in Slovakia shortly before its accession to the EU. It should be noted that these two investments had a determining role in the rapid rise of the FDI of this sector, while FDI significantly increased from almost $0 \%$ in 2002 to $9 \%$ in 2006 and finally reached approximately $6 \%$ in 2016 . There is a major increase in exports of vehicles and transport equipment accounting 29\% of the Slovakian exports in 2016 (UNCTAD) which were related to FDI that has taken place. It can be concluded that FDI attracted is mainly directed to the world market (second category).

In the food products sector there is a decrease in FDI from $8.8 \%$ in 1998 to $2 \%$ in 2016, while exports and imports remained relatively stable, constituting approximately $5 \%$ of the Slovakian imports and exports respectively (UNCTAD). This could mean that FDI of this sector has an unclear orientation (first or second category).

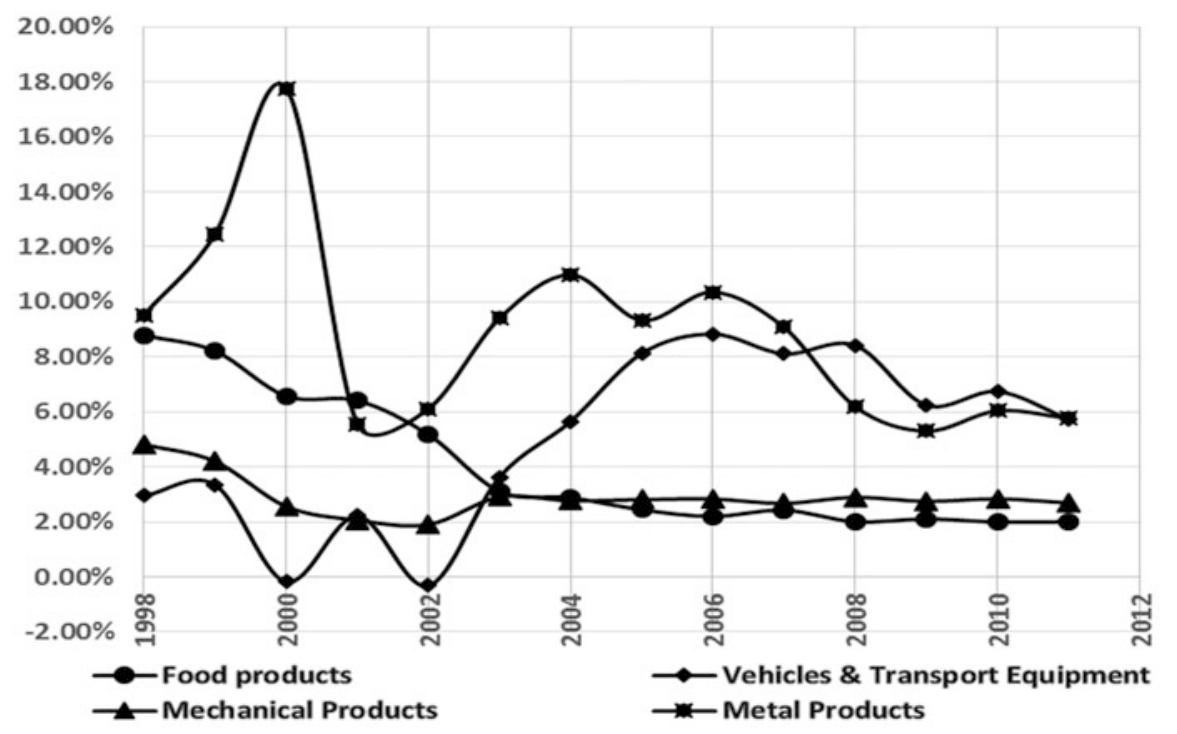

Fig. 6 FDI distribution by industry (1998-2011), (\% of total FDI positions of Slovakia). Source: OECD 
In mechanical products industry there was a major increase in both exports and imports for the whole period (UNCTAD) occupying almost the 33\% of Slovakian exports and imports respectively in 2016, while FDI remained stable at about $3 \%$ of the total Slovakian FDI. This probably means that FDI attracted is directed to both domestic and world market (first and second category). Moreover, a part of this sector may constitute inflows for other industries, such as Vehicles and Transport Equipment, whose exports also increase (first category).

Another major sector is the one of metal products. FDI had an upward trend until 2000 but diminished from $17.8 \%$ in 2000 to $5.8 \%$ in 2016 of the total FDI received, while exports and imports remained stable constituting approximately $10 \%$ of the Slovakian imports and exports respectively (UNCTAD). This could mean that part of this FDI is export-oriented (second category). Moreover, FDI of the sector of metal products could be significant inflows for other industries, such as mechanical products and vehicles, whose exports also increase (first category).

Slovakia's FDI, between the years 1998 and 2011, is mainly export-oriented (second category) while market-seeking FDI, apart from covering domestic needs, also consists important inflows for production for other industries.

\subsection{The Case of Greece}

\subsubsection{Market-Seeking FDI: Tariffs, GDP and National Currency}

As it can be seen from Fig. 7 Greece's FDI-w.t.percentage has an overall downfall trend while some fluctuations over some sub-periods can be noted. The FDI's downfall starts after 1984, i.e. 3 years after the country's accession to the European Economic Community (EEC). During the 1990's FDI continues to decline. The relative position of the country as a receiver of FDI deteriorated since FDI-w.t. percentage diminished from $0.84 \%$ of the world total in 1984 to $0.31 \%$ in 1995 , 2 years after Greek accession to the Single Market and even more to $0.18 \%$ in 2000 , finally reaching $0.10 \%$ of the world total in 2016 (UNCTAD). Therefore, it seems that the accession to the EU and the EMU has negatively affected FDI inflows. Moreover, FDI's course confirms the view that Greece is not an attractive country for FDI in the global economic environment.

After 1981, Greece had to accept the abolition of tariffs and capital control up to 1985, while the whole process was completed in 1993. Since Greece's main trading partners are EU countries (UNCTAD), the incentive of bypassing trade barriers for attracting market-seeking FDI does not seem to apply.

Moreover, the drachma's general appreciation in real terms during the 1990s (AMECO) ("pre-euro" era) could, to some extent, explain the non-attracting FDI. After 2001, the year that Greece accessed to the EMU, FDI stock remains on a low level and since Greece's main investors are EU countries FDI for exchange rate protection could not exist. 


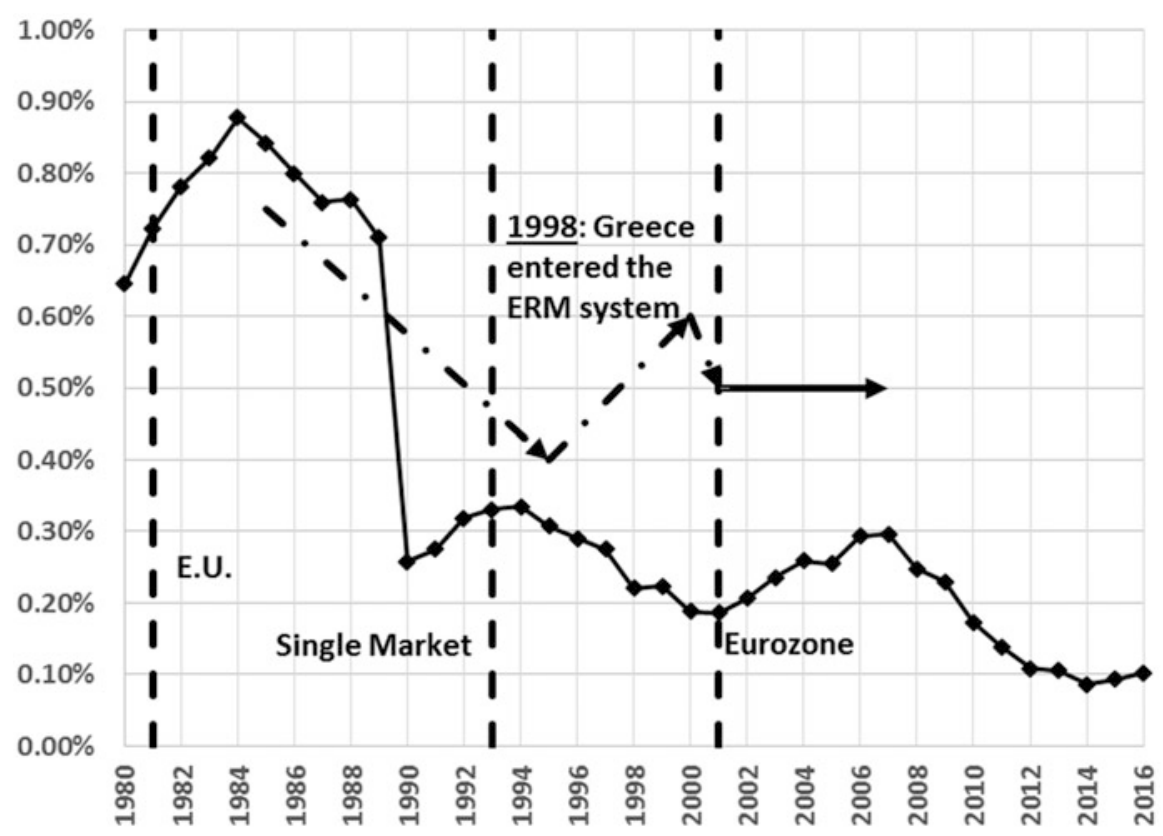

Fig. 7 FDI stock of Greece (\% of total world), 1980-2016. Source: UNCTAD \& IMF

Greece's geographical position like Romania's and Slovakia's, is not an incentive for attracting market-seeking FDI, taking into account that Greece's main investors (OECD) and trade partners are nearby countries of the EU (UNCTAD).

Greece's GDP and FDI-w.t.percentage have different directions until 2007 (AMECO). The correlation of the two variables is $\rho=0.12$ between the years 1994 and 2016, indicating that GDP changes are not an incentive for attracting market-seeking FDI. It must be noted that the continuous decline of GDP after 2008 is related to the global economic crisis and the austerity measures undertaken by the Greek government (Economakis et al. 2016).

\subsubsection{Export-Oriented FDI: Wage-Productivity Relationship and Geographic Proximity}

There is a sharp decrease in the Greece's ULC during the period 1983-1996 and for the years to follow, despite some fluctuations, it remains on low level. The correlation between FDI-w.t.percentage and ULC for the period 1981-2016 is strong and positive $(\rho=0.70)$, indicating that the improving cost competitiveness does not influence the level of FDI attracted by Greece.

Like Romania and Slovakia, the geographic proximity of Greece with the other EU countries, which are its main countries investors, could be an incentive for 
export-oriented FDI. However, this incentive is not activated in the case of Greece given the collapse of FDI.

\subsubsection{FDI and Trade Balance of Greece}

As it can be seen from Fig. 8, Greece's trade balance deteriorates, especially between the years 2002 and 2003, after the country's accession to the EMU. Greece's FDI-w. t.percentage had a downfall trend after 1984 with the only exception between the years 2002 and 2007 that had a small upward trend, which coincides for the years 2003-2005 with the trade balance amelioration. FDI-w.t.percentage and X/M have a strong negative relationship $(\rho=-0.74$ ), for the period 1994-2016 which means that FDI is not connected to the external trade. After 2008, Greece's trade balance improves as a result of the economic crisis and the restrictive measures which led to decreasing imports (Economakis et al. 2016) and FDI and trade balance are completely disconnected.

The FDI-w.t.percentage and exports have a strong negative correlation ( $\rho=-0.74$ ) between the years 1994 and 1016 indicating that FDI does not connect with exports. The relationship between imports and FDI-w.t.percentage is insignificant $(\rho=-0.08)$ between the years 1994 and 1016.

FDI in Greece is mostly attracted by non-tradable sectors or sectors that are not connected to the external trade. It is worth mentioning that in 2001 the service sector was absorbing the $60 \%$ and the industry sector the $35 \%$ of the total FDI received by

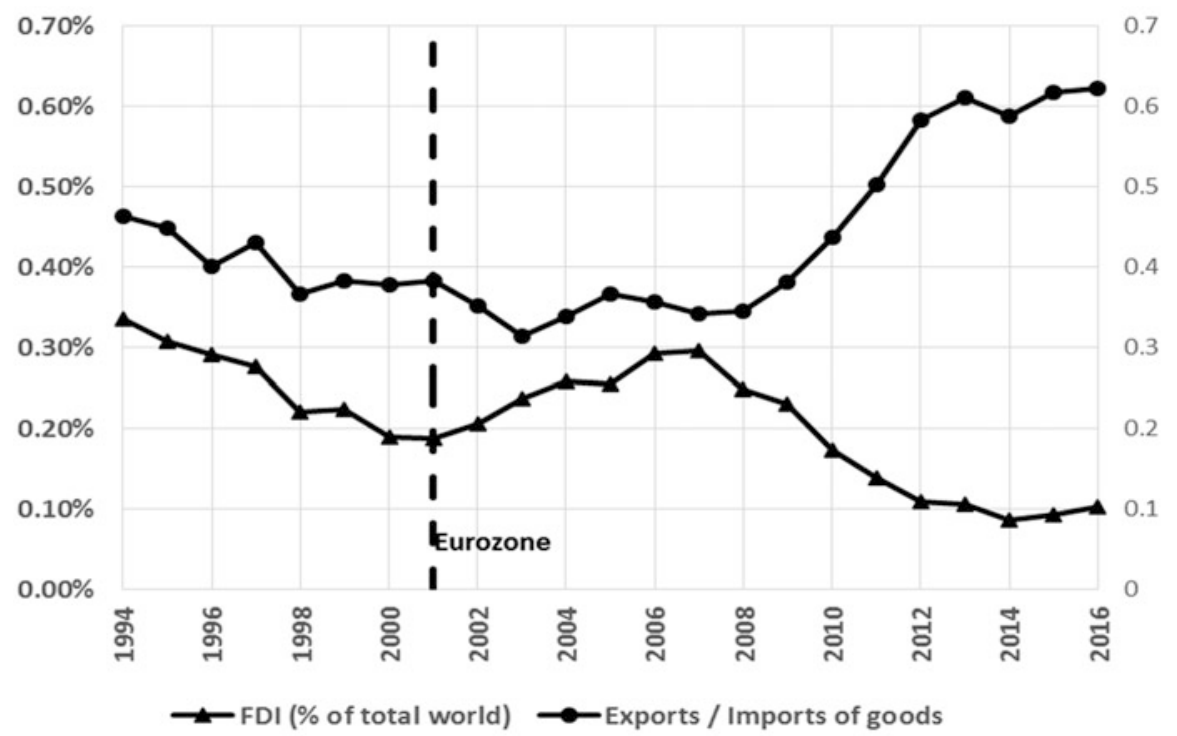

Fig. 8 FDI stock (\% total world) and exports/imports of goods of Greece (1994-2016). Source: UNCTAD \& AMECO 
Greece and in 2011 these percentages were almost the same (OECD), a fact that explains the trade balance deficit.

\subsubsection{Greece's FDI Positions by Industry \& Exports and Imports Structure}

As it can be seen from Fig. 9 FDI attracted by the Greece's manufacturing sector is lower than $40 \%$ of the total FDI received between the years 2001 and 2011 (OECD).

FDI attracted by the food products sector has a decrease from $19 \%$ in 2005 to $13.7 \%$ in 2016 (OECD). Moreover, the exports of the sector diminished from $30 \%$ in 1995 to $17.4 \%$ in 2014 , and finally reached $22.7 \%$ in 2016 , while imports seem to have remained relatively stable constituting $13 \%$ of the Greek imports during the years examined (UNCTAD). Therefore, FDI in this sector has an unclear orientation (first or/and second category).

As far as the pharmaceutical products are concerned, FDI also has an unclear orientation.

FDI of the fuel industry had fluctuations, absorbing $10.7 \%$ in 2005 and $6.3 \%$ in 2016 of the total FDI attracted (UNCTAD). Moreover, fuel imports could, by their nature, consist of inputs for other industries. Greece's fuel imports and exports also increased by approximately 30\% between the years 1995 and 2013, which means that this industry's products are both export-oriented and for domestic use as well.

Given the above, FDI in Greece's manufacturing sector remained low during the period 2001-2011.

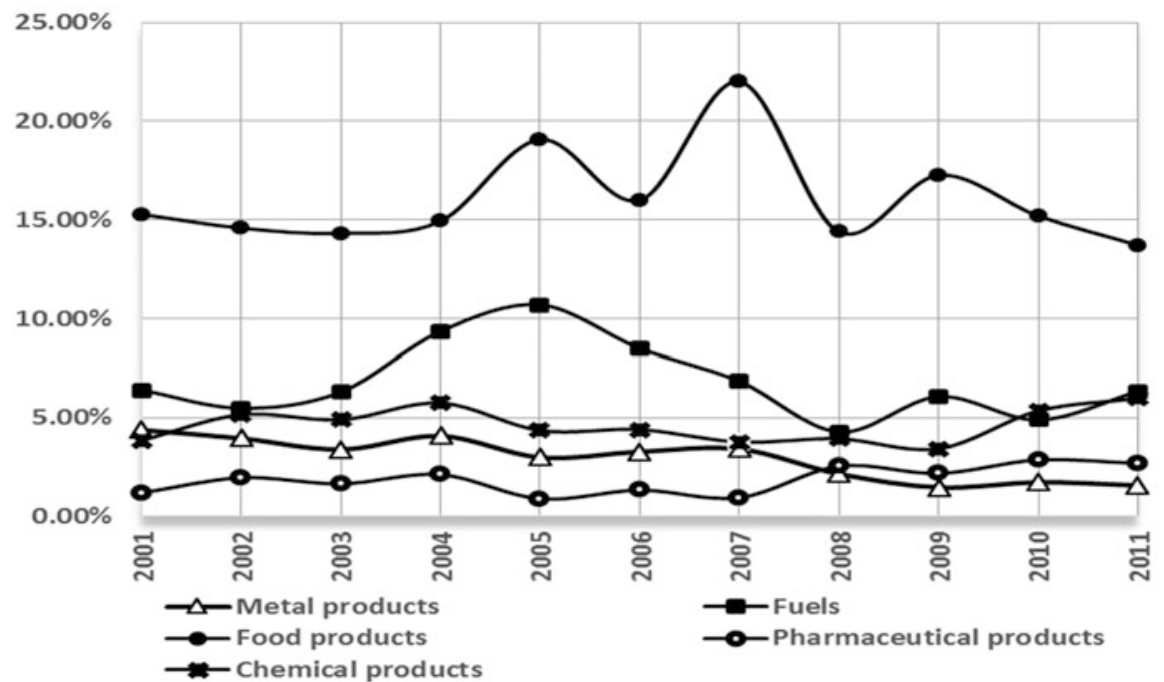

Fig. 9 FDI distribution by industry (2001-2011), (\% of total FDI positions of Greece). Source: OECD 


\section{Complexity}

Figure 10 presents the ECI of the three countries examined and also ECI of Germany as a benchmark, since "Germany is the second-most complex economy in the world after Japan and it is the second most diversified country after Italy" (Felipe and Kumar 2011, p. 10).

For Slovakia, ECI remains high throughout the period examined compared to the other two countries. Romania's ECI presents a clear upward trend during the recent years. Greece has a lower ECI compared to both Slovakia and Romania, and after 2010, i.e. during the ongoing Greek economic crisis, ECI turned negative.

From the definition of "economic complexity", Slovakia's export product mix is expected to be dominated by more "complex products", i.e. products of a higher technological level, while Greece's negative index indicates exports of low-tech products (OECD; Di Mauro et al. 2010).

Although primary and low technology products are Romania's main export products (UNCTAD), the downturn of exports of low technology products and the significant increase of exports of medium technology products since the mid-1990s (UNCTAD) can explain the upward trend of ECI during the recent years. Romania's FDI has followed the same trend. In particular, vehicles and transport equipment, which is a leading sector attracting Romanian FDI in recent years, is classified as sector of medium-high technological level, which indicates that ECI could be related, to some extent, to Romanian FDI.

Medium-tech products have dominated Slovakian exports since the mid-1990s while primary and low-tech export products have declined (UNCTAD), which

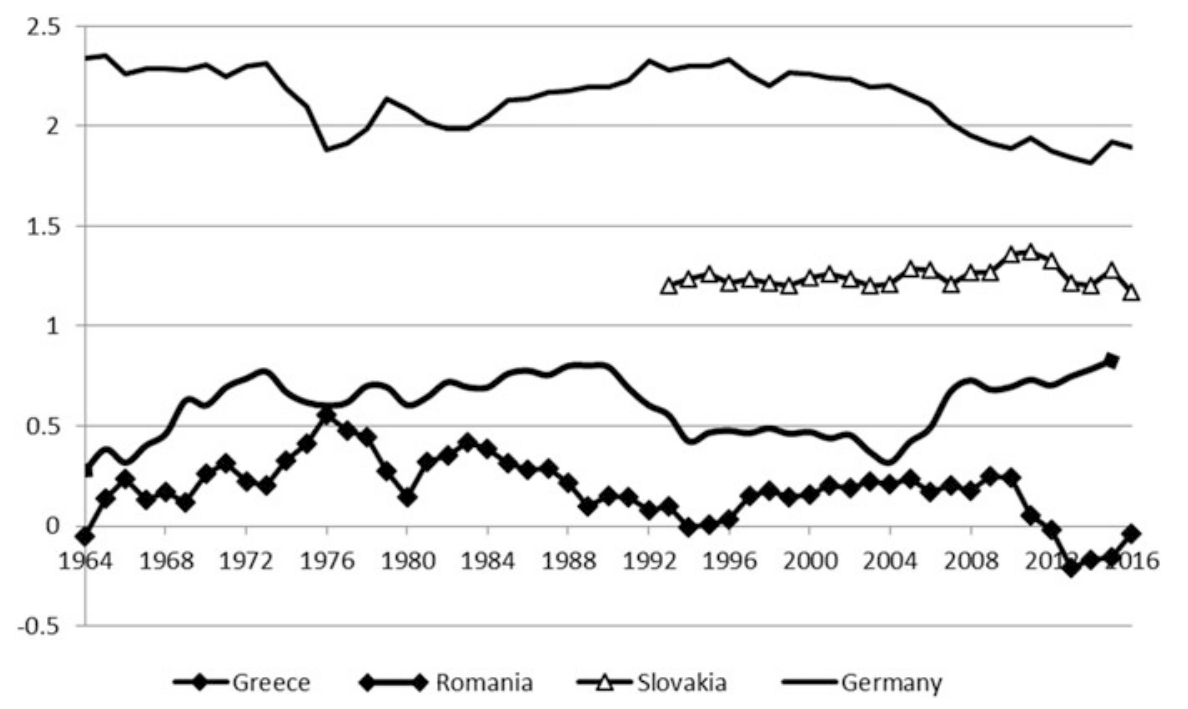

Fig. 10 Economic Complexity Intex (ECI) of Germany, Greece, Romania, Slovakia (1964-2016). Source: Atlas of Economic Complexity 
explains Slovakia's higher ECI. Given that the technological level of exports is positively related to the income elasticity of demand for exports and the latter is positively related to the amelioration of the trade of balance (Thirlwall 1991), Slovakian trade balance amelioration since 1998 is connected to the improving technological level of its exports. Moreover, there has been a significant increase of FDI in the sector of vehicles and transport equipment (medium-high technology level) but a decrease in the sectors of food products and metal products (low technology and low-medium technology, respectively). Consequently, Slovakia's relatively high economic complexity attracts specific FDI categories, especially the ones with a relatively higher level of economic complexity.

Finally, in the case of Greece, after the mid-1990s, the overwhelming dominance of primary product exports (UNCTAD) is linked to the low ECI of the country. The dominance of FDI in low-tech food products indicates that the country is classified as a simpler economy and therefore the economic complexity is not an incentive for attracting FDI.

\section{Conclusions}

Summarizing, the process of European integration does not seem to have had the same effect on the FDI attracted by Romania, Slovakia and Greece; however, it seems to be connected with a general downgrading of all countries as receivers of FDI. In the case of Romania and Greece, this deterioration is connected to the accession of the countries to the EU while in the case of Slovakia to the accession of the country to the EMU.

The effect of FDI on the trade balance for all countries examined in the context of European integration is rather vague. Throughout the period examined, FDI is either weakly connected (Slovakia) or disconnected (Romania and Greece) to the external trade. This indicates the limited impact of FDI of the first and second category on the total FDI in these countries despite the evidence of presence of FDI of the second category for Romania and Slovakia. It is worth noting that for Romania and Slovakia, FDI and trade balance followed opposite directions after the accession to the EU and the EMU, respectively. Greece's trade balance deteriorated or ameliorated independently of FDI after the country's accession to the EEC/EU.

For both Romania and Slovakia, although the incentive to circumvent tariff protectionism for attracting FDI has faded, the incentive to circumvent the exchange rate protection remains for foreign firms. In the case of Greece, the phasing out of tariffs and the exchange rate have had an effect on FDI attractiveness.

The size of the market has a positive relationship with FDI in the case of Romania and Slovakia but has no relationship with FDI in the case of Greece. Moreover, the low ULC seemed to attract FDI in the case of Romania and Slovakia but played no role in the case of Greece.

Greece's, Romania's, and Slovakia's geographical positions is not an incentive for attracting market-seeking FDI, taking into account that their main investors and 
trade partners are nearby countries of the EU. However, the geographic proximity of the three countries could be an incentive for export-oriented FDI.

Finally, economic complexity seems to explain, to some extent, the relative attractiveness of FDI of the three countries examined, and especially of FDI directed to more advanced technological sectors.

\section{References}

Andrei, D. M. (2014). Foreign direct investment (FDI) in Romania. Empirical evidence using restricted and unrestricted ECM models. Internal Auditing \& Risk Management, 2(34), 1-12.

Bratscht, Z. P. (2012). Effects of Slovakia's entry to EU (including adoption of euro) on Slovakia's car industry (pp. 1-21). Ypsilanti, MI: Eastern Michigan University.

Busch, K. (1992). Europe after 1992: Economic, ecological and social prospects of the single internal market. Athens: Kritiki [in Greek].

Di Mauro, F., Forster, K., \& Lima, A. (2010). The global downturn and its impact on euro area exports and competitiveness. Occasional Paper Series, ECB, 119.

Dobreanu, C. (2014). The German model. Forbes Magazine, 125(13 June), 86.

Economakis, G., Anastassopoulos, G., Koteas, A., \& Leonidas, M. (2005, October 13-15). Foreign direct investments: An inquiry into the Bulgarian case. Paper presented at the International Conference Managing Global Trends and Challenges in a Turbulent Economy, organized by the Department of Business Administration, University of Aegean, Chios.

Economakis, G., Frunzaru, V., \& Zisimopoulos, I. (2016). The economic crisis and industrial relations: Greece and Romania in comparison. East-West: Journal of Economics and Business, $X I X(1), 51-77$.

Fan, X., \& Dickie, P. M. (2000). The contribution of foreign direct investment to growth and stability: A post-crisis ASEAN-5 review. ASEAN Economic Bulletin, 17(3), 312-323.

Felipe, J., \& Kumar, U. (2011). Unit labor costs in the Eurozone: The competitiveness debate again (Working Paper 651). Levy Economics Institute of Bard College.

Giannitsis, S. (1983). The Greek industry: Growth and crisis. Athens: Gutenberg [in Greek].

Gibson, H. D. (2010). Development of the Greek economy by sector (1995-2003). In G. Economou, I. Sampathai, \& G. Simigiannis (Eds.), Current account of Greece: Causes of imbalances and policy proposals (pp. 335-364). Athens: Report of Bank of Greece [in Greek].

Hausmann, R., Hidalgo, C. A., Bustos, S., Coscia, M., Simoes, A., \& Yildirim, M. A. (2011). The Atlas of economic complexity. In Center for international development at Harvard University. Cambridge, MA: Puritan Press.

Iammarino, S., \& Pitelis, C. (1999, August). Foreign direct investment and less favoured regions: Greek FDI in Bulgaria and Romania. Paper presented at the ERSA Conference Paper.

International Monetary Fund (IMF). Accessed September 10, 2017, from http://data.imf.org/site_ moved.html

Lankes, H. P., \& Venables, A. J. (1996). Foreign direct investment in economic transition: The changing pattern of investments. The Economics of Transition, 4(2), 331-347.

Lim, E.-G. (2001). Determinants of, and the relation between, foreign direct investment and growth: A summary of the recent literature (IMF Working Paper). Accessed September 10, 2017, from http://www.imf.org/external/pubs/ft/wp/2001/wp01175.pdf

Marinescu, N., \& Szeles, M. R. (2010). Real convergence in the CEECs, euro area accession and the role of Romania. The European Journal of Comparative Economics, 7(1), 181-202.

Milios, J., \& Ioakeimoglou, I. (1990). The internationalization of Greek capitalism and the balance of payments. Athens: Exsantas [in Greek]. 
National Bank of Romania (NBR). (2004-2016). Foreign investment in Romania. Annual Reports. Accessed September 11, 2017, from http://www.bnr.ro/PublicationDocuments.aspx? icid $=14364$

Thirlwall, A. P. (1991). Krugman's 45-degree rule. Journal of Post Keynesian Economics, 14(1), 23-28.

Tsantilas, F. (2009). Greek investments in the Balkans (Diploma Thesis). University of Macedonia, Economic and Social Sciences, MSc. in Business Administration, Thessaloniki [in Greek]. Accessed September 10, 2017, from http://dspace.lib.uom.gr/bitstream/2159/13499/1/ TsantilasMsc2009.pdf

World Trade Organization (WTO). (1995, November). Slovakia. Accessed September 10, 2017, from https://www.wto.org/english/tratop_e/tpr_e/tp019_e.htm

\section{Online Sources}

AMECO. Accessed September 10, 2017, from http://ec.europa.eu/economy_finance/ameco/user/ serie/SelectSerie.cfm

Atlas of Economic Complexity - Center for International Development at Harvard University. Accessed September 10, 2017, from http://atlas.cid.harvard.edu/

OECD. Stat. Accessed September 10, 2017, from http://stats.oecd.org/

Slovak Republic.org. (n.d). European Union. Accessed September 13, 2017, from http://www. slovak-republic.org/eu/

UNCTAD. Accessed September 10, 2017, from http://www.unctad.org

Open Access This chapter is licensed under the terms of the Creative Commons Attribution 4.0 International License (http://creativecommons.org/licenses/by/4.0/), which permits use, sharing, adaptation, distribution and reproduction in any medium or format, as long as you give appropriate credit to the original author(s) and the source, provide a link to the Creative Commons licence and indicate if changes were made.

The images or other third party material in this chapter are included in the chapter's Creative Commons licence, unless indicated otherwise in a credit line to the material. If material is not included in the chapter's Creative Commons licence and your intended use is not permitted by statutory regulation or exceeds the permitted use, you will need to obtain permission directly from the copyright holder. 


\title{
Health Care and Migration: What Data Can Tell Us of the Hard-to-Measure Impact of Migrants on the European Health Systems
}

\author{
Guidi Caterina Francesca and Alessandro Petretto
}

\section{Background Framework}

One of the most fascinating aspects of health as a good is the different perspectives from which it can be studied since it has direct effect in the quality of life of individuals: guaranteeing its coverage and provision is a question of both equity and humanity. According to the consolidate literature of the Public Choice Theory (Samuelson 1954), health is a merit good (Musgrave 1959) with certain characteristics (Arrow 1963) present in both the demand and supply sides-such as externalities, information asymmetry, good experience, doctor-patient relationship, moral hazard, the adverse selection phenomenon (linked to uncertainty), and paternalistic public supply (Petretto 2017). Given these economic characteristics, health should be provided according to individuals' needs, a concept more related to the sphere of equity, rather than their ability or willingness to pay linked to the efficiency dimension. By its own nature, healthcare is an input into a productive process: medical treatment has a consumption effect-individuals feel better when they are healthier-and is an investment - the healthier you are, the more active in the labour market you are (Grossman 1972).

On the supply side, the two magisterial aspects are the provision model and pricesquantity of healthcare treatments available in the market, while on the demand side the three very important characteristics that we aim to investigate are access,

The original version of this chapter was revised. A correction to this chapter is available at https://doi.org/10.1007/978-3-030-11361-2_14.

G. Caterina Francesca $(\bowtie)$

European University Institute, Fisole, Florence, Italy

e-mail: caterina.guidi@eui.eu
A. Petretto $(\bowtie)$
University of Florence, Florence, Italy
e-mail: alessandro.petretto@unifi.it 
utilization, and quality of the outcome. In this chapter, we want to deepen the first two aspects - access and use — and study them according to the European welfare system provision towards migrants, one of the most vulnerable groups in European societies. We concentrate our study on what data and empirical evidence can tell us of the hardto-measure impact of migrants on European health systems.

One of the most compelling challenges is the adaptation of the health systems to migration's and mobility's new needs. Worldwide around 70\% of people still lack social protection coverage (ILO 2014) and about 400 million people do not have access to health services (WHO and WB 2015); among them the most vulnerable are migrants (OECD 2017). The adaptation of health systems to the migration phenomenon implies costs that can generate sustainability problems in the provision of services for nationals.

International migration represents $3.4 \%$ of the global population; considered as a whole, it would constitute the fifth-largest population in the world after China, India, the European Union (EU), and the United States of America (USA) (UNDESA 2017). Nearly two-thirds of all international migrants, around 76 million people, live in Europe (UNDESA 2017), establishing the continent as a recent migration destination. Indeed, between the Age of Discoveries and the mid-twentieth century, some 70 million people left their European homeland for overseas destinations and only in the last three decades has the number of third-country nationals entering the EU been greater than the number of EU citizens leaving for overseas destinations (Münz 2017). Today, almost 57.3 million citizens born outside their country of origin, accounting for $11 \%$ of the total population, equal to approximately 512 million people on 1 January 2017, in turn composed of 36\% intra-EU migrants and 64\% of foreign-born (Eurostat 2017). Around $6 \%$ of the latter group is represented by a growing second generation of migrants who have one or two foreign parents (Münz 2017).

To this we should add the so-called "humanitarian crisis", which has been worsened after the geopolitical imbalance post-9/11 and the Arab Spring uprising (Dustmann et al. 2016). In the years 2014-2016, about 1.8 million people (IOM 2017) entered EU ports in an irregular manner, mainly through the Mediterranean and the Western Balkans. More than 35\% arrived for humanitarian reasons, asking for asylum in various Northern and Western EU countries, creating a pressure never felt before on the European reception system (UNHCR 2017). This extra inflow-in addition to some 2 million first-residency permits issued to third-country nationals yearly - was unprecedented in size. In fact, in the years 2000-2013, the EU countries had only admitted fewer than 4 million asylum seekers and refugees altogether; on average fewer than 300,000 per year (Münz 2017).

The EU MS present different situations in terms of healthcare models, taxation systems, and the integration of foreign nationals. Compared to other countries with longer migration histories, such as Canada and the USA, the differences in access and use of health systems for foreigners are further differentiated according to their legal status-such as asylum seekers, refugees, long-term residents and so on.

In this chapter, we will analyze the health care provision for the European migrant population, underlining the differences between healthcare systems. Migration, indeed, may create more pressure on consolidated services or require new ones and can affect the demand and supply of health goods and care. In the next paragraph, we 
will consider the terms in which economic analysis addresses the complexity of migrant health needs. In the third paragraph, we will present the main themes for adapting the concept of health inequalities to the phenomenon of migration in Europe. The fourth paragraph is devoted to a concise review of the main types of healthcare and welfare systems in Europe. Concluding, the fifth paragraph contains some final considerations. The extensive bibliography we propose provides an idea of how much attention in this historical phase economic and econometric analyses have devoted to the implications of the migration phenomenon.

It is not possible to draw unequivocal and definitive conclusions from this review: The impact of migration on the welfare of industrialized countries is broad and heterogeneous, especially with regards to consolidated public economics and requires more in-depth and innovative theoretical reflections. Migration is a complex human phenomenon that imposes an arduous challenge to all social sciences, and public economics will certainly not come out of this without an inevitable methodological revision.

\section{Complexity of Migrant Health Needs and an Economic Analysis}

The classic Economics of Migration is focused on neoclassical models (Bencivenga and Smith 1997; Harris and Todaro 1970; Todaro 1969) and based on maximizing utility function and the New Labour Economics theories (Stark 1991, 1978). In the mainstream literature, the push and pull factors of migratory processes-such as expected salary, income, investment in human and social capital-have been analyzed in several contributions (Massey et al. 1993; Sjaastad 1962), particularly in Europe (Fouarge and Ester 2007; Hatton and Williamson 2002). The risk diversification in the choice of countries of destination (Simon 1983; Katz and Stark 1986) as the reason for the different investment in capital-cultural, financial, symbolic, and social capital (Bourdieu 1986) — tried to give an exhaustive portrait of migration economics, describing particularly what happens on the demand side of migration. In addition, the recent contributions to behavioural economics (Bertoli et al. 2015; Czaika 2015; Mankiw 1998; Kahneman and Tversky 1979), enrich the theoretical reference framework addressing the migrant perspective. In fact, the individual as the ethnic group beliefs towards destination countries and the functioning of the social networks are studied and considered to define the migratory investment or the aversion for status quo loss.

However, attention to the impact of migrants on destination country welfare systems is still scarce, especially in Europe. Some scholars, most notably Borjas (1994, 1999), argue that the various model of European welfare serves as a magnet for migrants given its average generosity and the high vulnerability suffered by people in transit, who are escaping from poverty, wars, and natural disasters. Brücker et al. (2002) have shown that, although it persists after controlling for migration characteristics, the effects of welfare attraction on migration composition are very moderate, and much more relevant than those exercised by wage levels or the expected unemployment rate in the destination countries (De Giorgi and 
Pellizzari 2009). Boeri (2009) found that less-skilled migrants are over-represented in the countries with more generous welfare and a higher probability to receive non-contributory benefits than natives, such as in Denmark, Finland, Norway, and Sweden, while the opposite happens in countries such as Austria, Germany, Spain, and the United Kingdom. However, this effect was not proven during the current refugee crisis in Europe: referring to a previous study (Pedersen et al. 2008), only a small proportion of asylum seekers declared they had chosen France due to the generosity of its welfare system. The analyses that utilize the level of public social expenditures out of the Gross Domestic Product (GDP) - in particular, public health care expenditure as a proxy for social state attractivity-do not support the magnet hypothesis (Gubert and Senne 2016).

Borjas and Trejo (1991) studied the public reception and assistance system of migrants in the USA and suggested that during the 1970s their increased utilization of assistance services may have been assessed by a change in the composition of cohorts of immigrants in terms of nationalities and time spent in the country. As also affirmed by Borjas and Hilton (1996), immigrants were more likely to be part of the Medicaid program in the 1980s and 1990s than the latest demographic cohorts. Implicitly, therefore, an increase in migration flows would add pressure on health resources (Preston 2014).

Hansen and Lofstrom (2003) looked at the use of the welfare system by migrants in Sweden, concluding that they are more likely to make use of its services than natives, but the effect decreases with the length of stay, as confirmed by Sarvimäki (2011) in Finland. Bratsberg et al. (2010, 2014), on the contrary, found migrants in Norway performed worse in the labour and social security market.

Barrett and McCarthy (2008) summarized most of the existing literature focusing on the nature of welfare systems in the destination countries and the use intensity made by migrants. They found that in Ireland immigrants are less welfare-dependent than natives, while in the United Kingdom they are more likely to use it: this effect, however, depends entirely on the higher dependence of Irish citizens on their welfare system. On the other hand, Dustmann et al. (2010) showed that there is a net benefit for the UK produced by migrants from countries entering the European Union in 2004. In fact, migrants from the $\mathrm{A} 8^{1}$ countries are much younger and then more likely to join the workforce and, therefore, less likely to benefit from social benefits, taking into account the eligibility criteria that non-EU migrants face. Dustmann and Frattini (2014) extended their analysis to immigrants from all countries, demonstrating once again the low levels of receiving benefits and the use of social housing in comparison with natives.

Grönqvist et al. (2012), studying the residential placement of asylum seekers in Sweden, analyzed the causal effects of health ethnic segregation and found that a positive association is observed between ethnic concentration and poor health outcomes-including hospital admissions_-but this disappears when controlling for residence status.

${ }^{1}$ Czech Republic, Estonia, Hungary, Latvia, Lithuania, Poland, Slovakia, Slovenia. 
However, the health of migrants is one of the biggest challenges for public health, causing serious problems of inequality and social exclusion in the destination countries. Understanding variables - founders and co-founders - is a fundamental exercise for studying the determinants of access, use, and quality of health services. Migrant health poses the central issue of public finance emerging from the social inclusion process: defending the sustainability of healthcare systems on the financial side is a prerequisite for tackling and winning this great challenge in Europe.

\section{Migrant Health Status in the Health Care Debate: From the Healthy Migrant Effect to the Exhausted Migrant Effect}

According to their specific framing, countries provide various levels of health coverage for different migratory groups and have different criteria for what is considered as a medical emergency (Stanciole and Huber 2009; Cuadra 2011; FRA 2011). The literature devoted to health, ethnic, and social inequalities is increasingly popular and explores several aspects of this topic, such as the higher risk of certain diseases among ethnic minorities (Hadjar and Backes 2013; Smith Nielsen and Krasnik 2010), the adopted behaviours, and the differences in the organization of health systems (Blom et al. 2016) as in the healthcare consumption for asylum seekers (Essink-Bot et al. 2012) and irregular migrants (Suess et al. 2014).

Historically, the hypothesis of the healthy migrant effect (HME) states that migrants have a better health status than non-migrants in the country of origin (Abraído-Lanza et al. 2000) thanks to a sort of comparative advantage (AcevedoGarcia et al. 2010), confirming that immigrants are not a sample of the population of origin but a positive health-based selection (Giuntella et al. 2016). Migrants from low-income countries have been described as "travellers of time" from the past and therefore have been exposed to fewer health risks, particularly for non-communicable diseases (Razum and Twardella 2002). However, it has recently been shown that being a migrant can be a decisive factor that negatively determines their health (Rechel et al. 2011), from arrival to stay in the destination countries (Marmot 2005; Marmot et al. 2012; Davies et al. 2009; Malmusi 2014; Giuntella and Stella 2017). Concurrent mechanisms such as poverty, discrimination in the labor market, travel, and living conditions in the host countries can influence migrants' opportunities in terms of healthcare received and suffered diseases, affecting the deterioration of their health over time (Acevedo-Garcia et al. 2010; Rechel et al. 2013). This is also known as the exhausted migrant effect, which also affects the health of second-generation migrants (Devillanova and Frattini 2016): a natural regression process towards the average health of the population (Giuntella 2013), an unhealthy assimilation process (Antecol and Bedard 2006; Giuntella and Stella 2017), and more likely to do dangerous work (Orrenius and Zavodny 2013; Giuntella and Mazzonna 2015). Additionally, adversities may be the cause of an 
increased incidence of mental disorders such as schizophrenia (Ingleby et al. 2012), anxiety, and depression (Lindert et al. 2009) among migrants. In some European countries, social exclusion and marginalization, which have also occurred since the second generation, seem to have a devastating effect.

Recently, Moullan and Jusot (2014) found that the differences in the health status of migrants and natives in Europe could be attributed to the large variation in health status of citizens in different European MS and countries. It has also shown that in times of economic crisis-given the high levels of unemployment and retirement uncertainty - migrants prefer to return to their country of origin for the salmon bias effect (Razum 2006). Indeed, the unhealthy re-migration effect is proven: migrants who have decent lives register a lower mortality risk in the host country than those whose migration has been ruinous, returning home even before they become manifestly sick (Razum et al. 2001).

The theory of acculturation - rather than the adoption of norms, values, and behaviours of the host countries - has been used to explain the changes in migrant health behaviours in the United Kingdom (Jayaweera and Quigley 2010) and in the USA (Giuntella 2016). Migrants present higher smoking levels than nationals, lower breastfeeding levels, and more high-fat diets, with a consequent increase in diabetes, cardiovascular disease, and cancer or, as in the case of Germany (Sander 2007), adverse mental health (Brand et al. 2017). If this theory is true, second or third generations of migrants may have similar health habits, like the local population of origin, as proved recently in the USA (Giuntella and Stella 2017) with the acceleration of obesity rates in the most recent migrant cohorts.

While the definition of who is an immigrant is recognized at the international level, it is still not very clear after how many years migrants can be considered part of the local population and their health risks like those of the local population (Grosser et al. 2016). In some countries, the second generation acquires the reception country's citizenship at birth—jus soli—while in others migrants remain "foreign" or "aliens" until the legal age (18 or 16 years old) or after some years of permanent residence-jus sanguinis (WHO 2010).

As stated by Razum (2006), an ideal migrant study should follow individuals before they migrate to the country of destination and, in the event of a return migration, back to the country of origin to better understand the direction of these effects and provide a real measurement.

\section{The Organization of the European Welfare Systems: Some Evidence}

\subsection{The Different European Welfare Systems Typologies}

The depth of health coverage, together with spending patterns and funding targets, are fundamental factors in determining the cost of the protection protection of the health for a country's citizens (Balabanova et al. 2013) as for the most vulnerable 
groups. Although health variability is linked to individual factors, the country of residence determines the quantity and supply of health services: In some European countries, populations are healthier due to the health coverage or levels of commodity of healthcare services (Bambra 2006; Mackenbach 2012; Eikemo et al. 2008a, b). Therefore, the famous distinction between countries based on welfare systems (Esping-Andersen 1990; Ferrera 1996; Petretto 2017) is central and differentiates countries into five groups: Anglo-Saxons, Bismarckian, Eastern, Scandinavian, and Southern, according to the liberal, conservative, post-socialist, or social-democratic policies pursed in the public sector. In Europe, countries are divided as follows:

- Anglo-Saxon: Ireland (IE) and England (UK);

- Bismarckian: Austria (AT), Belgium (BE), France (FR), Germany (DE), Luxemburg (LU), Netherlands (NL), and Switzerland (CH);

- Eastern: Bulgaria (BG), Czech Republic (CZ), Croatia (HR), Estonia (EE), Hungary (HU), Latvia (LV), Lithuania (LT), Poland (PL), Romania (RO), Slovak Republic (SK), and Slovenia (SL);

- Scandinavian: Denmark (DK), Finland (FI), Norway (NO), and Sweden (SE);

- Southern: Cyprus (CY), Greece (EL), Italy (IT), Malta (MT), Portugal (PT), and Spain (ES).

The social-democratic systems try to ensure wealth redistribution through laws and social security institutions, while the conservative systems present a low threshold of finance redistribution and a lower level of social welfare, but they respect the principle of subsidiarity. In contrast, liberal welfare regimes support a free-market economy with occasional interventions by the state and an average level of wellbeing guaranteed by the market while the post-socialist regimes have different mechanisms to produce welfare in their transition economies.

The idea is that the welfare system is central for migrant integration in terms of coverage and resources (Hadjar and Backes 2013). In addition, European healthcare systems differ from one country to another in various aspects such as the type of financial contribution, which influences the medical care provided to citizens and migrants. In summary (Thomson et al. 2009):

- National Health Service (NHS): the health services are mainly financed through taxation as in DK, ES, FI, IE, IT, MT, NO, PT, SE, and the UK;

- Social Health Insurance (SHI): social contributions are the main financial instrument; it is the most popular system in Europe as in AT, BE, CH, CZ, DE, EE, FR, HR, HU, LT, LU, NL, PO, RO, SK, and SL;

- Out-of-pocket payment (OOP): it is based only on private payment and very few European countries present this system as in BG, CY, EL, LV.

Although there is a positive trend in increasing funds for health spending and social protection (Honorati et al. 2015), comparing EU MS with other non-EU countries, some selected health expenditure flows present very high variability, as illustrated in Fig. 1.

Current health expenditure, as a proportion of GDP, has increased over the past decades in most EU countries: for the EU as a whole, it has increased from $7.9 \%$ in 


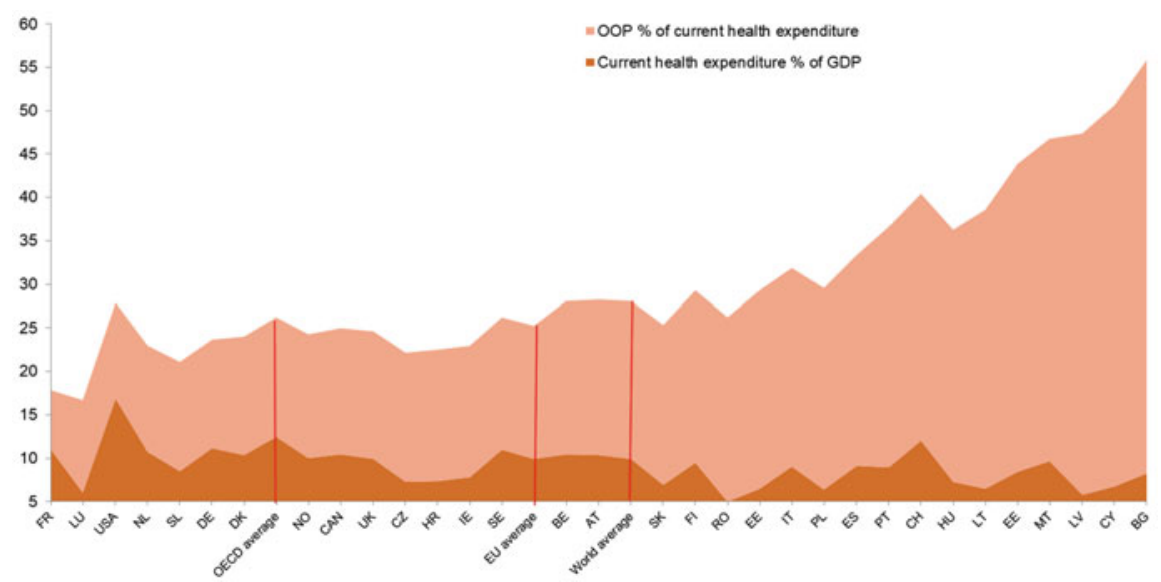

Fig. 1 Trends in current and private healthcare expenditure in EU MS, Canada, Norway, Switzerland, USA-2015. Source: Authors' elaboration based on data provided by World Bank-World Development Indicators (2018)

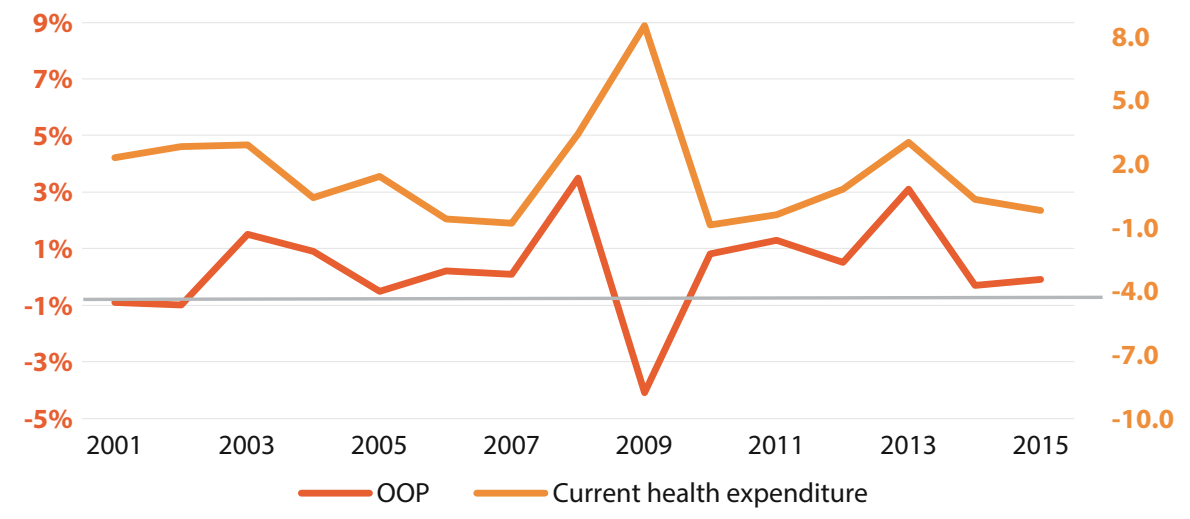

Fig. 2 Growth rates in currentand private health expenditure from 2001 to 2015 in the EU. Source: Authors' elaboration based on data provided by World Bank-World Development Indicators (2018)

2000 to $9.9 \%$ in 2015, while the share of OOP out of THE has substantially decreased in some countries and increased in others. As shown in Fig. 2, from the comparison between total and OOP health expenditure growth rates from 2001 to 2015, it can be noted that a decrease in the first corresponds an increase in the other and the current European trend is a progressive increase of OOP proportion of the private health expenditure (OECD and WB data 2017).

As shown in Fig. 3, assuming 2010 as the worst year in the panel of time crisis, in countries where the proportion of OOP expenditure out of the private health expenditure (PHE) increases, the Gini Index, which measures inequality in income distribution, follows the same path, determining a higher effect of health inequalities. 


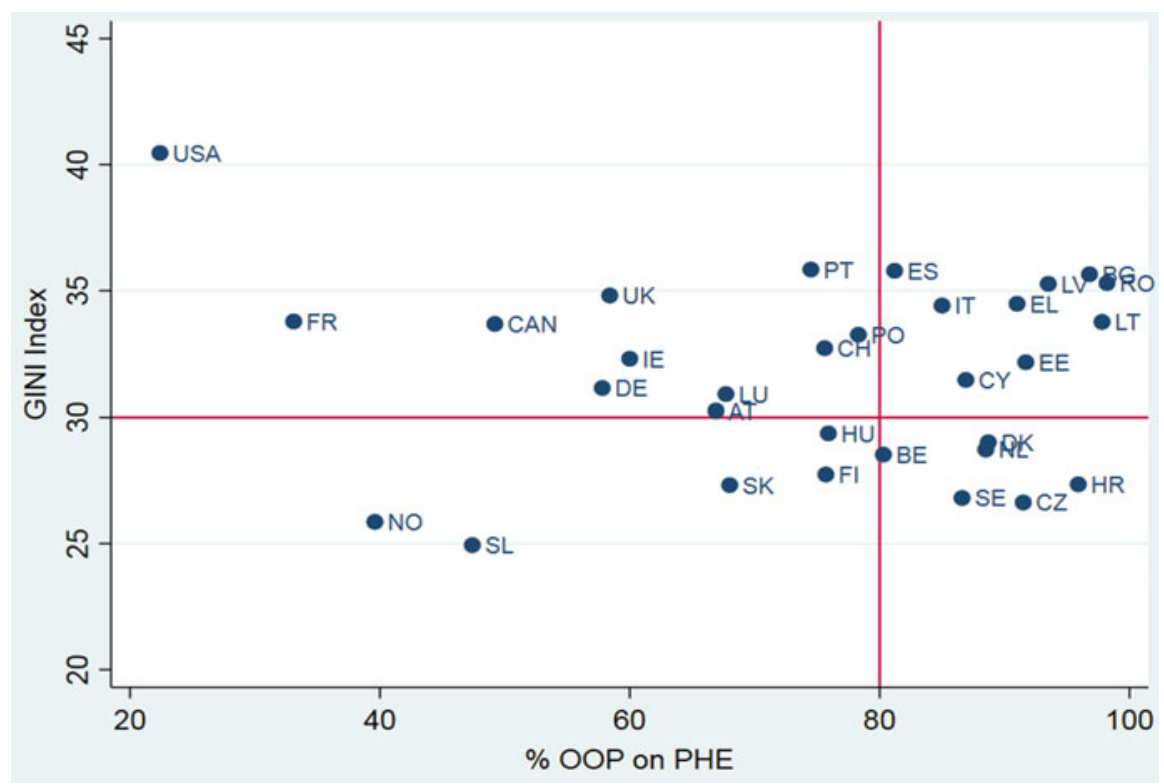

Fig. 3 Health inequality EU MSs, Canada, Norway, Switzerland, USA-2010. Source: Authors' elaboration based on data provided by World Bank-World Development Indicators (2018)

However, it is not easy to determine its final effect on health (European Commission 2013). The proportion of individuals covered by a private insurance varies widely among MS (Thomson et al. 2009): close to zero in CZ, ES, IC, LT, RO, and SV while FR, BE, LU, Sl, and NL present half of the population with access to private insurance, given that it can be complementary, supplementary, or duplicative to their health systems. Indeed, in more than one-third of EU countries, healthcare systems are financed by a mix of taxation and social contributions.

This does not lead to a unique impact on migrants in an EU characterized by deep structural differences and oppressed by a global economic and financial crisis (Dustmann et al. 2016). In addition, the socioeconomic inequalities of mortality and morbidity are no smaller in Scandinavian and SSN welfare countries than in the liberal Anglo-Saxon countries or those characterized by a Southern system or with more family-oriented public policies (Eikemo et al. 2008a, b).

Certainly, the educational gradient plays a central role since countries with the lowest average years of education — such as the Southern and Eastern European countries_-present the largest overall prevalence rates of illness, while the AngloSaxon countries have the lowest ones (Eikemo et al. 2008b). In general, first Scandinavian and then Anglo-Saxon regimes were observed to have better selfassessment $(\mathrm{SAH})$ than Bismarckian, Southern, and Eastern European welfare regimes given that the variety of cultural factors may influence the rational expectations of citizens (Navarro et al. 2003, 2006; Bambra 2006; Borrell et al. 2007; Eikemo et al. 2008a; Bambra and Eikemo 2009; Bergqvist et al. 2013). 


\subsection{Healthcare Expenditure and Reduction of Ethnic Inequalities}

The study of the impact of healthcare expenditure on reducing ethnic inequalities has recently received more attention since it might amplify differences between migrants and natives, especially first-generation immigrants (Blom et al. 2016). Taking for granted the hypothesis of the material deprivation and intersectionality of different disadvantages affecting migrants, it has been proved that language and cultural barriers impede the access and use of services despite the percentage of health expenditure dedicated (Ingleby 2012). Therefore, policies on socioeconomic deprivation may reach the lower quintiles of income but mostly native residents rather than migrants (Palencia 2014); while specific policy measures targeted to migrant health may really reduce these disadvantages (Mladovsky 2011), they may lead to friction between the poor with unforeseeable outcomes.

A further element of difference between the countries is the migrant integration policy model, based on the Migrant Integration Policy Index (MIPEX) scores produced by the Migrant Policy Group (Meuleman and Reeskens 2008). The main categories of countries are as follows:

- Assimilationist: based on the premise that migrants can be socially and culturally absorbed into the societies through a process of adaptation as in $\mathrm{CH}, \mathrm{FR}, \mathrm{DE}, \mathrm{IE}$, and LU;

- Exclusionist: where migrants are incorporated in certain spheres of life and excluded from others as in AT, BG, CY, CZ, DK, EE, EL, HU, LV, LT, MT, $\mathrm{PO}, \mathrm{RO}, \mathrm{SL}$, and SK;

- Multiculturalist: where ethno-cultural groups are given equal rights as the majority population in the different spheres of social life as in BE, ES, FI, IT, NL, PT, SE, and UK.

The number of studies utilizing MIPEX in their analyses to characterize the healthcare provision to different classes of citizens in European countries is considerable. A relationship between MIPEX and depression levels in migrants has been proven (Levecque and Van Rossem 2015), while it has not been found so explicative for comparing the subjective wellbeing of migrants and natives (Hadjar and Backes 2013) Malmusi (2014). Giannoni et al. (2016) demonstrated the impact of the migration policy on migrants' SAH: indeed, unsufficient integration policies worsen socioeconomic and health outcomes. As expected, countries that rely on the OOP system and adopt exclusionist policies also present lower percentages of public health expenditure while the majority of those with the NHS system also present a multicultural policy, asking their citizens lower percentages of out-of-pocket tax contributions.

As expected, countries relying on an OOP healthcare system and exclusionist policies also have lower public health spending, while most countries with SSNs also have a multicultural integration policy, requiring percentages of private personal contribution to lower health care. As empirical evidence shows, minority ethnic groups may have more health problems-higher mortality risk and lower levels of 
wellbeing - in European countries with more severe integration policies (Ikram et al. 2015; Hadjar and Backes 2013). The perceived group discrimination is associated with poor health outcomes in the first generation of migrants in Europe (Levecque and Van Rossem 2015) but not among their descendants, in particular in the assimilationist countries (Borrell et al. 2015). The length of stay, the acquisition of citizenship, and naturalization mitigate health exclusions and then the poor health outcomes after the first generation.

Several authors have demonstrated that health inequalities between migrants and non-migrants decrease or disappear, controlling their socioeconomic position (SEP). However, some authors argue that SEP can in turn be conditioned by ethnic origin and migrant status, and so caused by social exclusion processes (Davies et al. 2009; Malmusi et al. 2010; Rechel et al. 2013). As such, it should be treated as an unlawful inequality component (Mackenbach 2012) that must be overcome, as ethnic differences in the health sector should only be justified if the healthcare received meets the different health needs of all groups (Essink-Bot et al. 2012).

In addition, as shown in Fig. 4, the relationship between MIPEX health and the assessment of the quality of its health system extracted from the Eurobarometer (2014) confirms our intuition. On the vertical axis, the health policies in support of migrants in the EU MS are reported while the percentages of people who replied "Good" to the question "How do you evaluate the overall quality of your healthcare system?" are on the horizontal axis.

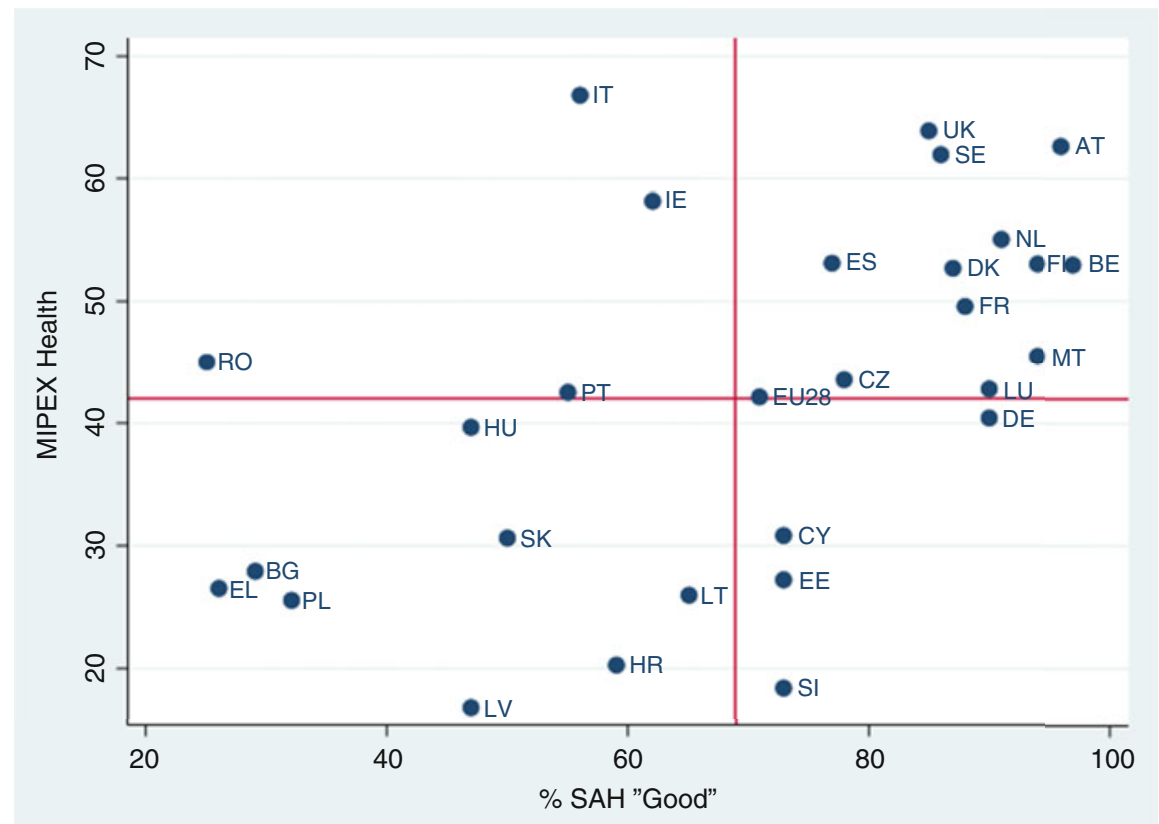

Fig. 4 MIPEX Health and Eurobarometer in EU MSs-2015. Source: Authors' elaboration on Eurobarometer (2014) and MIPEX Health (2015) data 
As can be seen, some country clusters are emerging: Eastern countries adopting exclusionist policies and with SHI or OOP financing systems provide the worse results in terms of migrant health, while Anglo-Saxon and Bismarckian countries, irrespective of the migration policies but presenting an NHS or SHI financing system, register the best performances. Indeed, migrant health seems to be strictly correlated with the overall healthcare system function and citizen satisfaction.

\section{Conclusions}

In this chapter we have analyzed the provision models of health care to migrant population, according to European healthcare systems. Migration, by creating more pressure on consolidated services or requiring new ones, affects the demand and supply of health goods. We first tried to consider the terms on which economic analysis addresses the complexity of migrant health needs, and then considered the adapting of health inequalities to the phenomenon of immigration. Second, we reviewed the main types of healthcare and welfare. There aren't any "one size fits all" conclusions applicable to all countries, proving that immigration is totally beneficial for public finances. There is also empirical evidence that encourages the affirmation that it is not a process that can be avoided in the history of humanity itself, especially in turbulent times: measuring the impact of migration on healthcare systems is an emerging issue for developed as well as developing countries, and contributes to the evaluation of the overall wealth of countries in providing services to their citizens.

We believe that, in the present state of art in public economics, it is not possible to draw unequivocal and definitive conclusions regarding the problem faced in this review: the theme is so broad, complex, and heterogeneous that it requires more in-depth and innovative theoretical reflections. Almost all the fundamental theorems are based on a given population and in absence of mobility, but migration is not just mobility. Migration is a complex human phenomenon that imposes an arduous challenge to all social sciences, and public economics will certainly not come out of this with an inevitable methodological revision.

On the specific issue of the impact on European public finances, there is no evidence that in Europe, legal migrants, especially the highly qualified ones, are net beneficiaries of social transfers by the state even though there is a residual dependence on their non-contributory character and that migrants are more likely to approach countries with more generous welfare systems (Preston 2014; Boeri 2009; Boeri et al. 2002). In several countries migrants have thus largely supported the local public finances and not affected public health sector performances (Alfano et al. 2016; Devillanova and Frattini 2016; Gimeno-Feliu et al. 2016; Giuntella and Mazzonna 2015; Wadsworth et al. 2016; Wadsworth 2013; Dustmann and Frattini 2014; Gee and Giuntella 2011; Steventon and Bardsley 2011).

Closing the doors of the welfare state (Boeri and Brücker 2005) should never be a solution for European countries, particularly in the health sector where it could 
generate pandemic emergencies of preventable diseases and create marginalized and excluded individuals, by definition, from health coverage. As explained by Alesina et al. (2001), Europeans have a greater public welfare state to offer than Americans since they are more likely to pursue redistribution policies, even when in favour of ethnic and racial minorities.

Moreover, according to Preston (2014), the economic and fiscal equilibrium between the different effects depends, inter alia, on the nature of fiscal and expenditure rules, the pressures of selection processes on the composition of migrants, and the stages of the economic cycle.

The problem will soon not be checking the economic and financial constraints and impacts on the welfare systems of the migratory phenomenon but rather equip the welfare systems themselves for a heterogeneous population in terms of average income and wealth levels. In this regard it is worth remembering Rechel et al. (2013) and Davies et al. (2009) who, using European datasets, found that health discrepancies between migrants and non-migrants disappear after control over their socioeconomic positions. In other words, the sustainability of health systems, within the broader welfare systems, will increasingly target the measures to contrast social inequalities rather than help the migratory phenomena as such: and it will concern the whole population, migrants as well as natives.

\section{References}

Abraído-Lanza, A. F., Dohrenwend, B. P., Ng-Mak, D. S., \& Turner, J. B. (2000). The Latino mortality paradox: a test of the "salmon bias" and healthy migrant hypotheses. American Journal of Public Health, 89(10), 1543-1548.

Acevedo-Garcia, D., Bates, L. M., Osypuk, T. L., \& McArdle, N. (2010). The effect of immigrant generation and duration on self-rated health among US adults 2003-2007. Social Science \& Medicine, 71(6), 1161-1172.

Alesina, A., Gaesler, E., \& Sacerdot, B. (2001). Why doesn't the US have a European-style welfare state? (Harvard Institute of Economic Research Working Papers 1933). Cambridge, MA: Harvard University Press.

Alfano, M., Dustmann, C., \& Fasani, F. (2016). Immigration and the UK, Reflections after Brexit (CREAM, Discussion Paper Series CPD 23/16). London.

Antecol, H., \& Bedard, K. (2006). Unhealthy assimilation: Why do immigrants converge to American health status levels? Demography, 43(2), 337-360.

Arrow, K. (1963). Uncertainty and the welfare economics of medical care. American Economic Review, 53(5), 941-973.

Balabanova, D., Mills, A., Conteh, L., Akkazieva, B., Banteyerga, H., Dash, U., Gilson, L., Harmer, A., Ibraimova, A., Islam, Z., Kidanu, A., Koehlmoos, T. P., Limwattananon, S., Muraleedharan, V. R., Murzalieva, G., Palafox, B., Panichkriangkrai, W., Patcharanarumol, W., Penn-Kekana, L., Powell-Jackson, T., Tangcharoensathien, V., \& McKee, M. (2013). Good health at low cost 25 years on: Lessons for the future of health systems strengthening. Lancet, 381(9883), $2118-2133$.

Bambra, C. (2006). Health status and the worlds of welfare. Social Policy and Society, 5, 53-62.

Bambra, C., \& Eikemo, T. A. (2009). Welfare state regimes, unemployment and health: A comparative study of the relationship between unemployment and self-reported health in 23 European countries. Journal of Epidemiological Community Health, 63, 92-98. 
Barrett, A., \& McCarthy, Y. (2008). Immigrants and welfare programmes: Exploring the interaction between immigrants' characteristics, immigrant welfare dependence and welfare policy. Oxford Review of Economic Policy, 24(3), 542-559.

Bencivenga, V., \& Smith, B. D. (1997). Unemployment, migration and growth. Journal of Political Economy, 105(3), 582-608.

Bergqvist, K., Åberg Yngwe, M., \& Lundberg, O. (2013). Understanding the role of welfare state characteristics for health and inequalities: An analytical review. BMC Public Health, 13., 1234, $1-20$.

Bertoli, S., Docquier, F., \& Ruyssen, I. (2015). Networks and migrants' intended destination, Paper presented at the GDRI Workshop on International Migration, CERDI, Clermont-Ferrand, November 2015.

Blom, N., Huijts, T., \& Kraaykamp, G. (2016). Ethnic health inequalities in Europe. The moderating and amplifying role of healthcare system characteristics. Social Science \& Medicine, 158, 43-51.

Boeri, T. (2009). Immigration to the land of redistribution. Economica, 77, 651-687.

Boeri, T., \& Brücker, H. (2005). Why are Europeans so tough on migrants? Economic Policy, (44), 629-704.

Boeri, T., Hanson, G., \& McCormick, B. (Eds.). (2002). Immigration Policy and the Welfare System. Oxford: Oxford University Press.

Borjas, G. (1994). The economics of immigration. Journal of Economic Literature, 32(4), 1667-1717.

Borjas, G. (1999). Immigration and welfare magnets. Journal of Labor Economics, 17(4), 607-637.

Borjas, G., \& Hilton, L. (1996). Immigration and the welfare state: Immigrant participation in means-tested entitlement programs. Quarterly Journal of Economics, 111(2), 575-604.

Borjas, G., \& Trejo, S. (1991). Immigrant participation in the welfare system. Industrial and Labor Relations Review, 44(2), 195-211.

Borrell, C., Espelt, A., Rodriguez-Sanz, M., Navarro, V., \& Kunst, A. E. (2007). Explaining variations between political traditions in the magnitude of socio-economic inequalities in selfperceived health. In Tackling Health Inequalities in Europe: Eurothine. Rotterdam: Erasmus Medical Center.

Borrell, C., Palència, L., Bartoll, X., Ikram, U., \& Malmusi, D. (2015). Perceived discrimination and health among immigrants in Europe according to national integration policies. International Journal of Environmental Research and Public Health, 12, 10687-10699.

Bourdieu, P. (1986). The forms of capital. In J. Richardson (Ed.), Handbook of theory and research for the sociology of education (pp. 241-258). New York: Greenwood.

Brand, T., Samkange-Zeeb, F., et al. (2017). Acculturation and health-related quality of life: Results from the German National Cohort migrant feasibility study. International Journal of Public Health, 62(5), 521-529.

Bratsberg, B., Raaum, O., \& Røed, K. (2010). When minority labor migrants meet the welfare state. Journal of Labor Economics, 28(3), 633-676.

Bratsberg, B., Raaum, O., \& Røed, K. (2014). Immigrants, labour market performance and social insurance. Economic Journal, 124(580), 644-683.

Brücker, H., Epstein, G., McCormick, B., Saint-Paul, G., Venturini, A., \& Zimmermann, K. (2002). Managing migration in the European welfare state. In T. Boeri, G. Hanson, \& B. McCormick (Eds.), Immigration policy and the welfare system: A report for the fondazione rodolfo debenedetti (pp. 1-167). Oxford: Oxford University Press.

Cuadra, C. B. (2011). Right of access to health care for undocumented migrants in EU: A comparative study of national policies. European Journal of Public Health, 22(2), 267-271.

Czaika, M. (2015). Migration and economic prospects. Journal of Ethnic and Migration Studies, 41 (1), 58-82.

Davies, A. A., Basten, A., \& Frattini, C. (2009). Migration: A social determinant of the health of migrants. Geneva: International Organization for Migration. 
De Giorgi, G., \& Pellizzari, M. (2009). Welfare migration in Europe. Labour Economics, 16(4), 353-363.

Devillanova, C., \& Frattini, T. (2016). Inequities in immigrants' access to health care services: Disentangling potential barriers. International Journal of Manpower, 37(7), 1-29.

Dustmann, C., \& Frattini, T. (2014). The fiscal effects of immigration to the UK. The Economic Journal, 124(580), 593-643.

Dustmann, C., Frattini, T., \& Halls, C. (2010). Assessing the fiscal costs and benefits of A8 migration to the UK. Fiscal Studies, 31, 1-41.

Dustmann, C., Fasani F., Frattini T., Minal L., \& Schonberg U. (2016). On the economics and politics of refugee migration (Centro Studi Luca D'Agliano Development Studies Working Papers N. 403). Turin.

Eikemo, T. A., Bambra, C., Judge, K., \& Ringdal, K. (2008a). Welfare state regimes and differences in self-perceived health in Europe: A multilevel analysis. Social Science \& Medicine, 66, 2281-2295.

Eikemo, T. A., Huisman, M., Bambra, C., \& Kunst, A. E. (2008b). Health inequalities according to educational level in different welfare regimes: A comparison of 23 European countries. Sociology of Health \& Illness, 30(4), 565-582.

Esping-Andersen, G. (1990). The three worlds of welfare capitalism. Princeton, NJ: Princeton University Press.

Essink-Bot, M. L., Lamkaddem, M., Jellema, P., Nielsen, S. S., \& Stronks, K. (2012). Interpreting ethnic inequalities in healthcare consumption: A conceptual framework for research. European Journal of Public Health, 23(6), 922-926.

Eurobarometer. (2014). Patient safety and quality of care: Report. Special Eurobarometer n. 41.

European Agency for Fundamental Rights (FRA). (2011). Migrants in an irregular situation: Access to healthcare services in 10 European Union Member States. Vienna: FRA.

European Commission. (2013). Health inequities in the EU: Final report of a consortium. Consortium lead: Sir Michael Marmot.

Eurostat. (2017). Migration and migrant population statistics explained, Brussels. Accessed November 28, 2018.

Ferrera, M. (1996). The "Southern model" of welfare in social Europe. Journal of European Social Policy, 6, 17-37.

Fouarge, D., \& Ester, P. (2007). Factors determining international and regional migration in Europe. European Foundation for the Improvement of Living and Working Conditions (EUROFOUND), Dublin.

Gee, E. R., \& Giuntella, G. O. (2011). Medicaid and ethnic networks. The BE Journal of Economic Analysis \& Policy, 11(1), 1-31.

Giannoni, M., Franzini, L., \& Masiero, G. (2016). Migrant integration policies and health inequalities in Europe. BMC Public Health, 16, 463, 1-14.

Gimeno-Feliu, L. A., Calderón-Larrañaga, A., Diaz, E., Poblador-Plou, B., Macipe-Costa, R., \& Prados-Torres, A. (2016). Global healthcare use by immigrants in Spain according to morbidity burden, area of origin, and length of stay. BMC Public Health, 16(450), 1-12.

Giuntella, O. (2013). Why does the health of immigrants deteriorate? Evidence from birth records (IZA Discussion Paper No. 7588). Bonn.

Giuntella, O. (2016). Assimilation and health: Evidence from linked birth records of second- and third-generation Hispanics. Demography, 53, 1976-2004.

Giuntella, O., \& Mazzonna, F. (2015). Do immigrants improve the health of natives? Journal of Health Economics, 43, 140-153.

Giuntella, O., \& Stella, L. (2017). The acceleration of immigrant unhealthy assimilation. Health Economics, 26, 511-518.

Giuntella, O., Nicodemo, C., \& Vargas Silva, C. (2016). The impact of immigration on health and health care: Evidence from the United Kingdom. In F. Fasani (Ed.), Refugees and economic migrants: Facts, policies and challenges (VoxEU.org Book) (pp. 99-114). London: CEPR Press. 
Grönqvist, H., Johansson, P., \& Niknami, S. (2012). Income inequality and health: Lessons from a Refugee Residential Assignment Program (IZA Discussion Paper No. 6554). Bonn.

Grosser, A., Razum, O., Vrijkotte, T. G. M., Hinz, I.-M., \& Spallek, J. (2016). Inclusion of migrants and ethnic minorities in European birth cohort studies: A scoping review. European Journal of Public Health, 26, 1-6.

Grossman, M. (1972). On the concept of health capital and the demand for health. Journal of Political Economy, 80(2), 223-249.

Gubert, F., \& Senne, J.N. (2016). Is the European Union attractive for potential migrants? An investigation of migration intentions across the world (OECD Social, Employment and Migration Working Papers, No. 188). Paris: OECD.

Hadjar, A., \& Backes, S. (2013). Migration background and subjective well-being: A multilevel analysis based on the European Social Survey. Comparative Sociology, 12, 645-676.

Hansen, J., \& Lofstrom, M. (2003). Immigrant assimilation and welfare participation: Do immigrants assimilate into or out of welfare? Journal of Human Resources, 38(1), 74-98.

Harris, J. R., \& Todaro, M. P. (1970). Migration, unemployment and development: A two-sector analysis. The American Economic Review, 60, 126-142.

Hatton, T.J., \& Williamson, J.G. (2002). What fundamentals drive world migration? (NBER Working Paper No. 9159). National Bureau of Economic Research.

Honorati, M., Gentilini, U., \& Yemtsov, R. (2015). The state of social safety nets 2015. Washington, DC: World Bank Group.

Ikram, U. Z., Snijder, M. B., Fassaert, T. J. L., Schene, A. H., Kunst, A. E., \& Stronks, K. (2015). The contribution of perceived ethnic discrimination to the prevalence of depression. European Journal of Public Health, 25, 243-248.

Ingleby, D. (2012). Ethnicity, migration and the social determinants of health agenda. Psychosocial Intervention, 21, 331-341.

Ingleby, D., Krasnik, A., Lorant, V., \& Razum, O. (Eds.). (2012). Health inequalities and risk factors among migrants and ethnic minorities. Maku, Belgium.

International Labour Organization. (2014). World social protection report 2014-15. Geneva: International Labor Organization.

International Organization for Migration. (2017). Accessed November 28, 2018, from http:// migration.iom.int/europe/

Jayaweera, H., \& Quigley, M. (2010). Health status, health behaviour and healthcare use among migrants in the UK: Evidence from mothers in the Millennium Cohort Study. Social Science \& Medicine, 71, 1002-1010.

Kahneman, D., \& Tversky, A. (1979). Prospect theory: An analysis of decision under risk. Econometrica, 47(2), 263-291.

Katz, E., \& Stark, O. (1986). Labor migration and risk aversion in less developed countries. Journal of Labor Economics, 4(1), 134-149.

Levecque, K., \& Van Rossem, R. (2015). Depression in Europe: Does migrant integration have mental health payoffs? A cross-national comparison of 20 European countries. Ethnic Health, $20,49-65$.

Lindert, J., von Ehrenstein, O. S., Priebe, S., Mielck, A., \& Brahler, E. (2009). Depression and anxiety in labor migrants and refugees - A systematic review and meta-analysis. Social Science \& Medicine, 69, 246-257.

Mackenbach, J. P. (2012). The persistence of health inequalities in modern welfare states: The explanation of a paradox. Social Science \& Medicine, 75(4), 761-769.

Malmusi, D. (2014). Immigrants' health and health inequality by type of integration policies in European countries. European Journal of Public Health, 25(2), 293-299.

Malmusi, D., Borrell, C., \& Benach, J. (2010). Migration-related health inequalities: Showing the complex interactions between gender, social class and place of origin. Social Science \& Medicine, 71(9), 1610-1619.

Mankiw, G. N. (1998). Principles of microeconomics. Stanford: Cenage Learning/South-Western College. 
Marmot, M. G. (2005). Social determinants of health inequalities. Lancet, 365, 1099-1104.

Marmot, M. G., Allen, J., Bell, R., Bloomer, E., \& Goldblatt, P. (2012). WHO European review of social determinants of health and the health divide. Lancet, 380(15), 1011-1029.

Massey, D. S., Arango, J., Hugo, G., Kouaouci, A., Pellegrino, A., \& Taylor, J. E. (1993). Theories of international migration: A review and appraisal. Population and Development Review, 19(3), 431-466.

Meuleman, B., \& Reeskens, T. (2008). The relation between integration policy and majority attitudes toward immigration: An empirical test across European countries. Paper presented at the Dag van de Sociologie, Leuven.

Mladovsky, P. (2011). Migrant health policies in Europe. In B. Rechel, P. Mladovsky, W. Devillé, B. Rijks, R. Petrova-Benedict, \& M. McKee (Eds.), Migration and health in the European Union (pp. 185-202). Maidenhead: Open University Press.

Moullan, Y., \& Jusot, F. (2014). Why is the "healthy migrant effect" different between European countries? European Journal of Public Health, 24(1), 80-86.

Münz, R. (2017). The integration of migrants and refugees: A European synopsis. In R. Bauböck \& M. Tripkovic (Eds.), The integration of migrants and refugees (pp. 7-19). Florence: European University Institute, Robert Schuman Centre for Advanced Studies.

Musgrave, R. A. (1959). The theory of public finance: A study in public economy. New York: McGraw-Hill.

Navarro, V., et al. (2003). The importance of the political and the social in explaining mortality differentials among the countries of the OECD, 1950-1998. International Journal of Health Services Research, 33, 419-494.

Navarro, V., et al. (2006). Politics and health outcomes. Lancet, 368(9540), 1033-1037.

Organization for Economic and Cooperation Development. (2017). Interrelations between public policies, migration and development. Paris: OECD Publishing.

Orrenius, P. M., \& Zavodny, M. (2013). Chapter 11: Immigrants in risky occupations. In A. Constant \& K. F. Zimmermann (Eds.), International Handbook on the Economics of Migration. Cheltenham: Edward Elgar.

Pedersen, P. J., Pytlikova, M., \& Smith, N. (2008). Selection and network effects: Migration flows into OECD countries 1990-2000. European Economic Review, 52(7), 1160-1186.

Petretto, A. (2017). Economics of Institutions and Law. Florence: DISEI.

Preston, I. (2014). The effect of migration on public finances. The Economic Journal, 124, 569-592.

Razum, O. (2006). Commentary: Of salmon and time travelers: Musing on the mystery of migration mortality. International Journal of Epidemiology, 34, 919-921.

Razum, O., \& Twardella, D. (2002). Time travel with Oliver Twist: Towards an explanation for a paradoxically low mortality among recent immigrants. Tropical Medicine and International Health, 7(1), 4-10.

Razum, O., Zeeb, H., \& Rohrmann, S. (2001). The healthy migrant effect: Not merely a fallacy of inaccurate denominator figures. International Journal of Epidemiology, 29, 191-192.

Rechel, B., Mladovsky, P., Devillé, W., Rijks, B., Petrova-Benedict, R., \& McKee, M. (Eds.). (2011). Migration and health in the European Union. Maidenhead: Open University Press.

Rechel, B., Mladovsky, P., Ingleby, D., Mackenbach, J. P., \& McKee, M. (2013, April). Migration and health in an increasingly diverse Europe. Lancet, 381, 1235-1245.

Samuelson, P. (1954). The pure theory of public expenditure. The Review of Economics and Statistics, 3(4), 387-389.

Sander, M. (2007). Return migration and the "healthy immigrant effect" (SOEP papers on Multidisciplinary Panel Data Research N. 60).

Sarvimäki, M. (2011). Assimilation to a welfare state: Labor market performance and use of social benefits by immigrants to Finland. Scandinavian Journal of Economics, 113(3), 665-688.

Simon, H. A. (1983). Reason in human affairs. Stanford: Stanford University Press.

Sjaastad, L. A. (1962). The costs and returns of human migration. Journal of Political Economy, 70 (5), 80-93. 
Smith Nielsen, S., \& Krasnik, A. (2010). Poorer self-perceived health among migrant and ethnic minorities versus the majority population in Europe. International Journal of Public Health, 55, 357-371.

Stanciole, A. E., \& Huber, M. (2009). Access to healthcare for migrants, ethnic minorities and asylum seekers in Europe. In Policy Brief. Vienna: European Centre for Social Welfare and Policy Research.

Stark, O. (1978). Economic-demographic interactions in agricultural development: The case of rural-to-urban migration. Rome: Food and Agriculture Organization.

Stark, O. (1991). The migration of labor. Malden, MA: Basil Blackwell.

Steventon, A., \& Bardsley, M. (2011). Use of secondary care in England by international immigrants. Journal of Health Services Research \& Policy, 16(2), 90-94.

Suess, A., Ruiz Perez, I., Ruiz Azarola, A., \& March Cerdà, J. C. (2014). The right of access to health care for undocumented migrants: A revision of comparative analysis in the European context. European Journal of Public Health, 24(5), 712-720.

Thomson, S., Foubister, T., \& Mossialos, E. (2009). Financing health care in the European Union. Copenhagen: WHO Regional Office for Europe.

Todaro, M. P. (1969). A model of labor migration and urban unemployment in less developed countries. The American Economic Review, 59, 138-148.

United Nations Department of Economic and Social Affairs. (2017). Trends in international migrant stock: The 2017 revision. New York.

United Nations High Commissioner for Refugees. (2017). Accessed November 28, 2018 from http://data.unhcr.org/mediterranean/regional.php

Wadsworth, J. (2013). Mustn't grumble: Immigration, health and health service use in the UK and Germany. Fiscal Studies, 34(1), 55-82.

Wadsworth, J., Dhingra, S., Ottaviano, G., \& Van Reenen, J. (2016). Brexit and the impact of immigration on the UK (Centre for Economic Performance Paper Brexit 05). London School of Economics.

World Health Organization. (2010). How health systems can address health inequities linked to migration and ethnicity. Copenhagen: Regional Office for Europe.

World Health Organization and World Bank. (2015). Tracking universal health coverage: First global monitoring report. Geneva/Washington, DC: World Health Organisation and World Bank Group.

Open Access This chapter is licensed under the terms of the Creative Commons Attribution 4.0 International License (http://creativecommons.org/licenses/by/4.0/), which permits use, sharing, adaptation, distribution and reproduction in any medium or format, as long as you give appropriate credit to the original author(s) and the source, provide a link to the Creative Commons licence and indicate if changes were made.

The images or other third party material in this chapter are included in the chapter's Creative Commons licence, unless indicated otherwise in a credit line to the material. If material is not included in the chapter's Creative Commons licence and your intended use is not permitted by statutory regulation or exceeds the permitted use, you will need to obtain permission directly from the copyright holder.

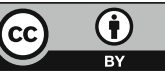




\title{
The Multiple Impact of Education Gaps in Romania
}

\author{
Diana-Maria Cismaru and Nicoleta Corbu
}

\section{Literature Review}

The systemic perspective in education presents two important applications of functional analysis: the ecological approach, from which was derived the concept of sustainable development in education (Dale and Newman 2005), and the perspective focused on the concept of quality, a concept that emphasizes the need to increase the effectiveness and performance of educational systems (Alexander 2000). Reflecting on the differences between the European and United States systems of education, Sallis (2014, p.10) reviewed the principles and indicators in Total Quality Management (a perspective from which emerged a series of instruments and indicators that influenced the educational institutions' management) and observed that in the US, educational institutions, most of them private, have a market-view orientation and are centred more on efficacy and profit. By contrast, in Europe the educational institutions are focused on quality of knowledge and services, relying more on public confidence.

Reviewing over 200 studies on education published in 20 years, Glewwe et al. (2011, pp. 22-25) synthesized the impact factors on three important elements: the infrastructure and educational resources, the characteristics of teachers, and the organization of school; A more recent study (Ganimian and Murnane 2016) identified four "lessons" learnt from more than 50 countries to increase students' achievements, among which was reducing the costs of going to school.

This chapter has been prepared with financial support granted in the project "State of the Nation. Designing an innovative instrument for evidence-based policy-making" (SIPOCA 11, MySMIS 118305), which is co-financed by the European Social Fund through the Operational Programme Administrative Capacity 2014-2020.

D.-M. Cismaru $(\bowtie) \cdot$ N. Corbu $(\bowtie)$

National University of Political Studies and Public Administration, Bucharest, Romania e-mail: diana.cismaru@comunicare.ro; nicoleta.corbu@comunicare.ro 
According to the human capital perspective, education is an investment of current resources (time, effort, money) in exchange for future returns (Harmon et al. 2001, p. 3). Several authors explored the returns of education, associating it with material individual benefits such as a better position on the labour market or increased earnings (Card 1999; Rouse 2007), the improvement of occupational status, and an increased social mobility (Buchmann and Hannum 2001, p. 89). On the other hand, synthesizing studies from over several decades, Wolfe and Haveman (2002, pp. 104-105) presented several non-material outcomes of education: better relationships, better health, longer life, more educated children.

The emphasis on education outcomes raises the issue of gaps, whether they are created between social categories, territorial units (countries, regions) or societies. The issue of education gaps has been considered a strategic problem to be addressed in future policies (Glewwe et al. 2011). Several types of education gaps have been documented in studies: for example, social class and race as sources of gaps since the beginning of school have been demonstrated in the case of American children (Hemphill and Vanneman 2011; Garcia and Weiss 2015); gender inequality was also investigated, considering the influence on economic growth in the long term (Klasen 2002; Breen et al. 2009). Disadvantaged groups and poverty were identified as bases for educational inequality (Duncan et al. 2011) and as priority targets in evidence-based policies for increasing education equity (Ladd 2012). Not only were the factors that influence gaps investigated in studies but also the features of the gaps, such as differences in participation and achievement (Reardon et al. 2014).

While questioning the effectiveness of education systems, several studies explored the variety of factors that shape educational inequality on multiple levels: Buchmann and Hannum (2001) identified four categories of factors: (a) macrostructural forces shaping educational stratification (education policies, funding); (b) the impact of family background on educational attainment and achievement; (c) school factors related to educational outcomes; (d) the impact of education on social mobility in developing regions. The authors also discuss the lack of research on the influence of communities in education outcomes, and the need to initiate cross-country studies.

The overlapping of gaps between developed and less developed societies was one of the issues debated by researchers in education. Glewwe and Muralidharan (2015, pp. 10-11) observed that in the less developed countries, the conversion of the participation rate in outcomes of education (knowledge and skills) is weak. The main challenges identified for increasing quality of results in education in developing countries were improving access to pre- and post-primary education, using technology to improve pedagogy, management and accountability, and developing appropriate policies to support private schools (Kremer et al. 2013, p. 299). Evaluating progress in education by reviewing 115 impact evaluation studies in 33 countries, Murnane and Ganimian (2014, pp. 43-44) discovered several effects of policies: reducing costs of school improves participation but not achievement while providing information about school quality and return of schooling improves achievement, and also daily experience of students' and teachers' incentives improve pupils' achievements. 


\section{Methodology}

In the context exposed in the previous section, we aim at identifying the main aspects of educational inequalities in the case of Romania and their impact on future development. To this purpose, we conducted a secondary data analysis using official data from UNESCO and Eurostat databases. The basis for analysis consists of three key indicators: gross enrolment ratio, the average rate of early leavers from education and training, and tertiary educational attainment. These indicators were selected because they provide integrative insights into the results of educational processes, are subject to educational policies and, at the same time, targets of Europe 2020 strategies. Thus, the gross enrolment ratio shows the proportion of pupils enrolled in a specific level of education, regardless of age, expressed as a percentage of the population in the official age group corresponding to this level of education. The early school leavers are defined as the persons aged 18-24 for whom the highest level of education attained is ISCED 0,1 or 2 . Finally, the tertiary educational attainment indicator is defined as the share of the population aged 30-34 who have successfully completed a tertiary education programme (ISCED 5-6). Additionally, we use a support indicator, the structure of population by level of educational attainment. The research questions guiding the analysis are:

RQ1. What are the particularities of educational inequalities among the Romanian regions of development in terms of level of education attained?

RQ2. In regard to the level of educational attainment, what are the tendencies of evolution in Romania in comparison with the tendencies of evolution in other European countries?

RQ3. What are the changes in the Romanian structure of population in terms of level of educational attainment in the last ten years?

The general objective of this contribution is to identify disparities within regions, and within the Eastern European region (in the context of the European Union as a benchmark), aiming at distinguishing patterns of development in education for Romania, in comparison with other patterns of development, and the potential consequences of this evolution.

\section{Findings}

In Romania, the development of schools, which are mainly public, depends mainly on the level of public financing of education, which was the lowest in Europe (around 2,7\% of GDP in the last years) (Eurostat, 2014, last available data, variable educ_uoe_fine06). The low level of financing is reflected in the decrease of enrolment at all levels and the teachers' lack of motivation, transforming the human resources in education into a persistent problem. In 2015, the average net monthly earning in education was approximately 420 euros, less than the earnings in other 


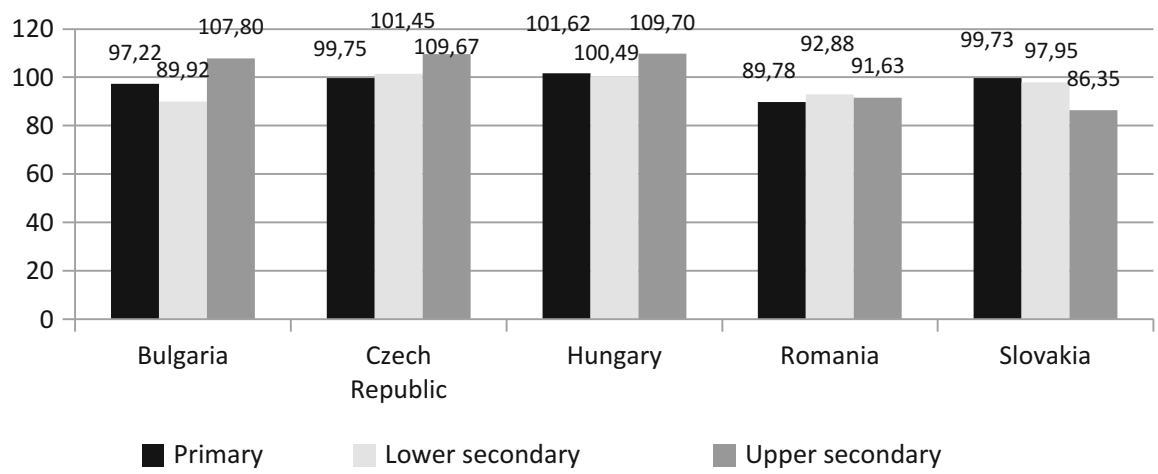

Fig. 1 Gross enrolment ratio in primary, lower secondary and upper secondary levels in $2015(\%)$. (The latest year with available data is 2015; there is no data available for Poland and Slovenia (newest data for these countries dates from 2013). Source: UNESCO, http://data.uis.unesco.org/ index.aspx?queryid $=142 \#$

fields such as insurance, public administration, consultancy, and communications (Romanian National Institute of Statistics, variable FOM106E).

The gross enrolment ratio is important because it reveals the share of participation in the different cycles of education. In Romania, the positive evolution of enrolment rates between 2002 and 2008 was influenced by public policies and a moderate economic improvement. But, after 2008, enrolment decreased in primary, lower secondary and upper secondary levels (UNESCO, variable "Gross enrollment rates, by level of education"). For example, for the upper secondary level, the decrease was of approximately 4-5\% after 2012, reaching 91.6\% in 2015. When comparing Romania with other former communist countries, Romania had, in 2015, the lowest level of participation in primary school (89.78\%) (Fig. 1), while the other four countries selected had levels of participation between 97.22\% (Bulgaria) and $101.62 \%$ (Hungary). Moreover, the gross enrolment ratio in lower secondary level in Romania was 92.88\%, lower than the Czech Republic, Slovakia, and Hungary.

The evolution of tertiary educational attainment (Fig. 2) is included in the same pattern. Even if Romania has made significant progress in ten years, increasing from 8.9 to $25.6 \%$, it still remains the lowest percentage among the former communist countries, and rather far from the average share in the European Union $39.1 \%$ in 2016). In Poland, for example, the share of population aged 30-34 with higher education was $44.6 \%$ in 2016 .

The third indicator selected for this study, the rate of early school leavers, reveals the other side of the gap between Romania and the other European countries. Thus, Romania has the highest level of this indicator in the European Union $(18.6 \%$ in 2016), while the mean in European Union decreased to $10.7 \%$. The former communist countries have lower levels or approximately the same level with the EU mean value (Fig. 3).

The rate of early school leavers by residence explains the source of the country gap of Romania. Thus, in 2016, if the rate of early school leavers in Romanian cities 


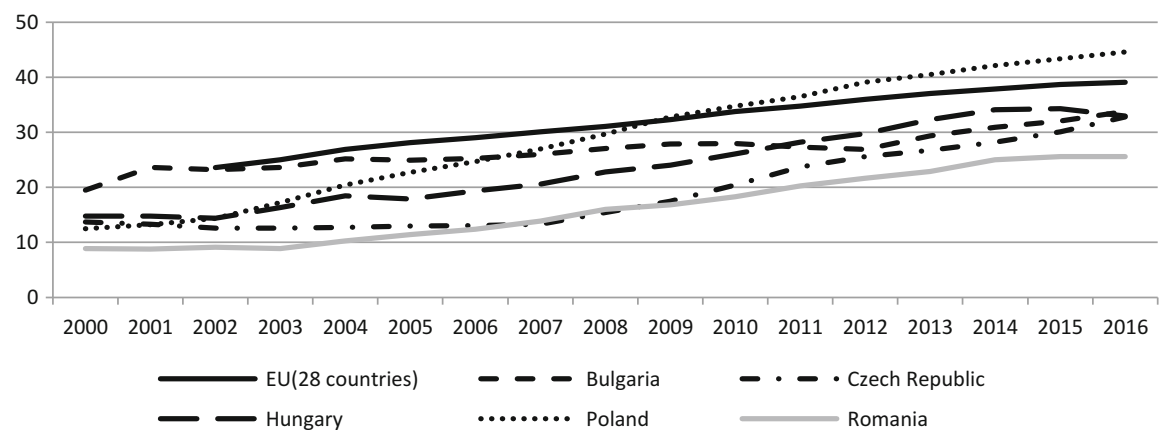

Fig. 2 Tertiary educational attainment (30-34 years) (\%). Source: Eurostat, variable edat_lfse_12

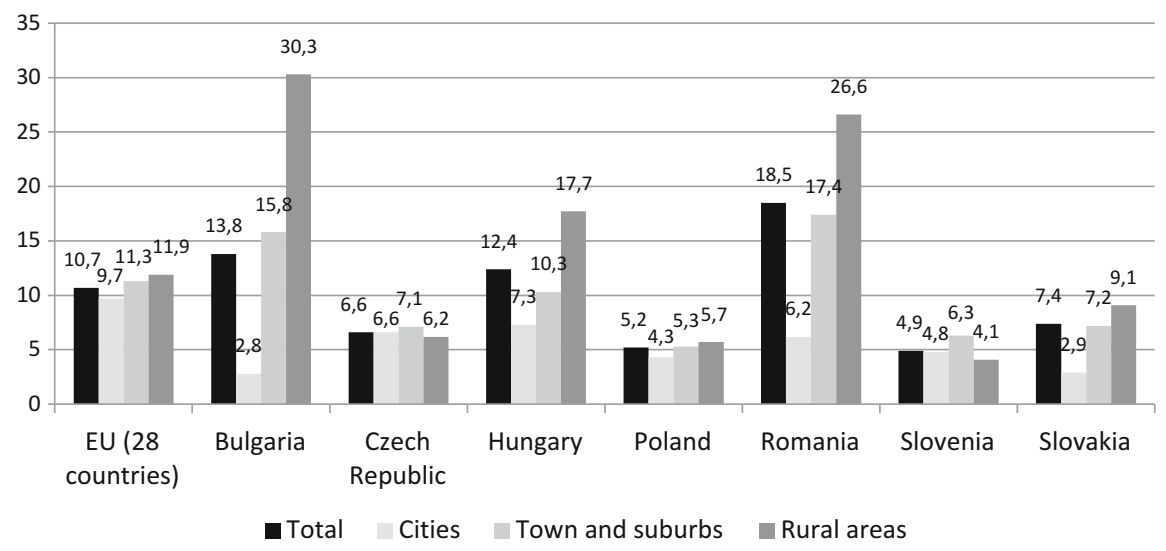

Fig. 3 The rate of early school leavers (18-24 years), by residence, in 2016. Source: Eurostat, variable edat_lfse_30

is comparable with the same rate in the developed European countries and with the EU mean, the rates in Romania's towns and suburbs (17.4\%) and, respectively, in rural areas $(26.6 \%)$ are much higher in comparison with the same rate in cities (only $6.2 \%$ ). Romania and Bulgaria are the only two countries with a large difference created by residence (Fig. 3).

The evolution of the two indicators considered above should be interpreted in connection with the changes in the structure of population by level of instruction. For the entire adult population (aged 25-64 years) the changes are slower, while for the younger age group, changes might be more easily obtained as the effect of policies. Thus, for the population aged 30-34 in different European countries (Table 1), several patterns of evolution can be identified. In some European countries, with a high share of population with a low level of instruction (ISCED 0-2) and a low share of population with tertiary education (ISCED 5-8), a positive change registered in 
Table 1 Population aged 30-34 in different European countries by level of educational attainment (2000, 2007, 2016-comparison)

\begin{tabular}{|c|c|c|c|c|c|}
\hline Country & Level of education & Level of education & 2000 & 2007 & 2016 \\
\hline \multirow[t]{3}{*}{ EU ( 28 countries) } & Low & ISCED 0-2 & & 21.7 & 17.2 \\
\hline & Medium & ISCED 3-4 & & 48.3 & 43.7 \\
\hline & High & ISCED 5-8 & & 30.1 & 39.1 \\
\hline \multirow[t]{3}{*}{ Belgium } & Low & ISCED 0-2 & 27.4 & 18.9 & 17.5 \\
\hline & Medium & ISCED 3-4 & 37.5 & 39.6 & 37.0 \\
\hline & High & ISCED 5-8 & 35.2 & 41.5 & 45.6 \\
\hline \multirow[t]{3}{*}{ Bulgaria } & Low & ISCED 0-2 & 23.7 & 17.9 & 17.9 \\
\hline & Medium & ISCED 3-4 & 56.8 & 56.1 & 48.3 \\
\hline & High & ISCED 5-8 & 19.5 & 26.0 & 33.8 \\
\hline \multirow[t]{3}{*}{ Greece } & Low & ISCED 0-2 & 30.9 & 25.8 & 17.1 \\
\hline & Medium & ISCED 3-4 & 43.7 & 47.9 & 40.2 \\
\hline & High & ISCED 5-8 & 25.4 & 26.3 & 42.7 \\
\hline \multirow[t]{3}{*}{ France } & Low & ISCED 0-2 & 26.0 & 18.1 & 14.2 \\
\hline & Medium & ISCED 3-4 & 46.5 & 40.5 & 42.2 \\
\hline & High & ISCED 5-8 & 27.4 & 41.4 & 43.6 \\
\hline \multirow[t]{3}{*}{ Italy } & Low & ISCED 0-2 & 44.2 & 34.8 & 28.8 \\
\hline & Medium & ISCED 3-4 & 44.2 & 46.7 & 45.1 \\
\hline & High & ISCED 5-8 & 11.6 & 18.6 & 26.2 \\
\hline \multirow[t]{3}{*}{ Hungary } & Low & ISCED 0-2 & 18.6 & 15.4 & 14.1 \\
\hline & Medium & ISCED 3-4 & 66.7 & 64.0 & 53.0 \\
\hline & High & ISCED 5-8 & 14.8 & 20.6 & 33.0 \\
\hline \multirow[t]{3}{*}{ Poland } & Low & ISCED 0-2 & 11.3 & 8.5 & 5.3 \\
\hline & Medium & ISCED 3-4 & 76.2 & 64.4 & 50.1 \\
\hline & High & ISCED 5-8 & 12.5 & 27.0 & 44.6 \\
\hline \multirow[t]{3}{*}{ Portugal } & Low & ISCED 0-2 & 74.3 & 60.2 & 33.9 \\
\hline & Medium & ISCED 3-4 & 14.4 & 20.3 & 31.5 \\
\hline & High & ISCED 5-8 & 11.3 & 19.5 & 34.6 \\
\hline \multirow[t]{3}{*}{ Romania } & Low & ISCED 0-2 & 12.1 & 20.0 & 23.4 \\
\hline & Medium & ISCED 3-4 & 78.9 & 66.0 & 51.0 \\
\hline & High & ISCED 5-8 & 8.9 & 13.9 & 25.6 \\
\hline \multirow[t]{3}{*}{ Spain } & Low & ISCED $0-2$ & 49.2 & 35.0 & 35.4 \\
\hline & Medium & ISCED 3-4 & 21.7 & 24.2 & 24.5 \\
\hline & High & ISCED 5-8 & 29.2 & 40.9 & 40.1 \\
\hline
\end{tabular}

Source: Eurostat, variable edat_lfse_12

only ten years (this is the case of Portugal, Italy, and Greece). In other countries with the same problem, the levels of indicators stagnated during the last 10 years (the case of Spain). In a third group of countries, such as Belgium and France, an analysis of the indicators shows a substantial decrease of population with low levels of instruction (ISCED 0-2) until 2007, and an improvement to a certain extent after 2007. In other countries, such as Poland, the share of people with low levels of instruction 
was rather small, and then decreased even more in the last ten years. Finally, in Romania, the share of population aged 30-34 years with a high level of instruction increased after 2007 from 14 to $25.6 \%$ (almost reaching the national objective in Europe 2020 Strategy), but increased more in the population with medium levels of instruction (ISCED 3-4), whose share decreased in the same period from 66 to $51 \%$ (Bulgaria and Hungary are in the same situation). At the same time, the share of population aged 30-34 years having a low level of education (ISCED 0-2) slightly increased after 2007 (from 20 to $23 \%$ ). Romania is the only case in which the problem became very prominent in 2007 (the share of population aged 30-34 with a low level of instruction doubled from 2000 to 2007) and also the only one for which the share of population with a low level of instruction increased instead of decreased (Table 1).

The same analysis performed on the whole adult population (aged 25-64) reveals slower changes in the three strata of the population. In the group of former communist countries, Romania has the highest share of individuals with a low level of instruction $(23.3 \%$ in 2016) and the lowest share of persons with a high level of instruction (17.4\% in 2016). Also, we observe again that the increase in the share of the population aged 25-64 years with a high level of instruction was produced to the detriment of those with a medium level of instruction (which decreased from $63 \%$ in 2007 to $59.4 \%$ in 2016), while those with a low level of instruction only slightly decreased, from $25 \%$ in 2007 to $23.3 \%$ in 2016 (Fig. 4).

Continuing the analysis of the educational attainment for the Romanian regions of development, we observe strong differences. Thus, in Bucharest-Ilfov, the most developed region of Romania, the tertiary educational attainment was $47.8 \%$ in 2016 (higher than the average level of the EU for this indicator-39.1\% in 2016), while the rate of early school leavers was only $10 \%$ in the same year (almost equal with the average level of EU). By contrast, in the other regions, the highest level of tertiary

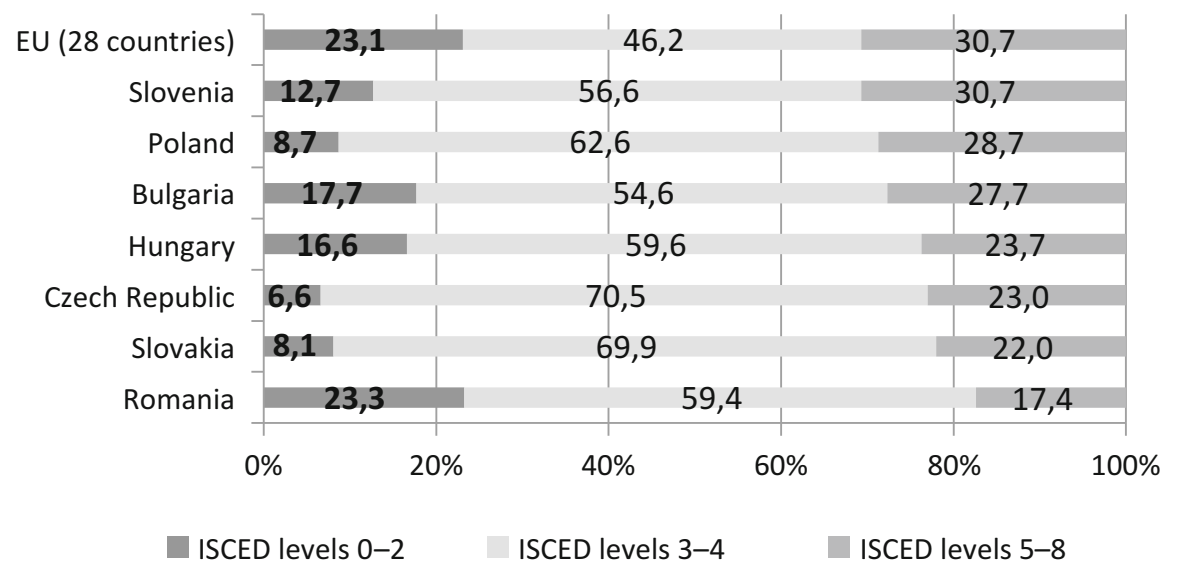

Fig. 4 Population aged 25-64 years by level of educational attainment, 2016 (\%). Source: Eurostat, variable edat_lfse_04 


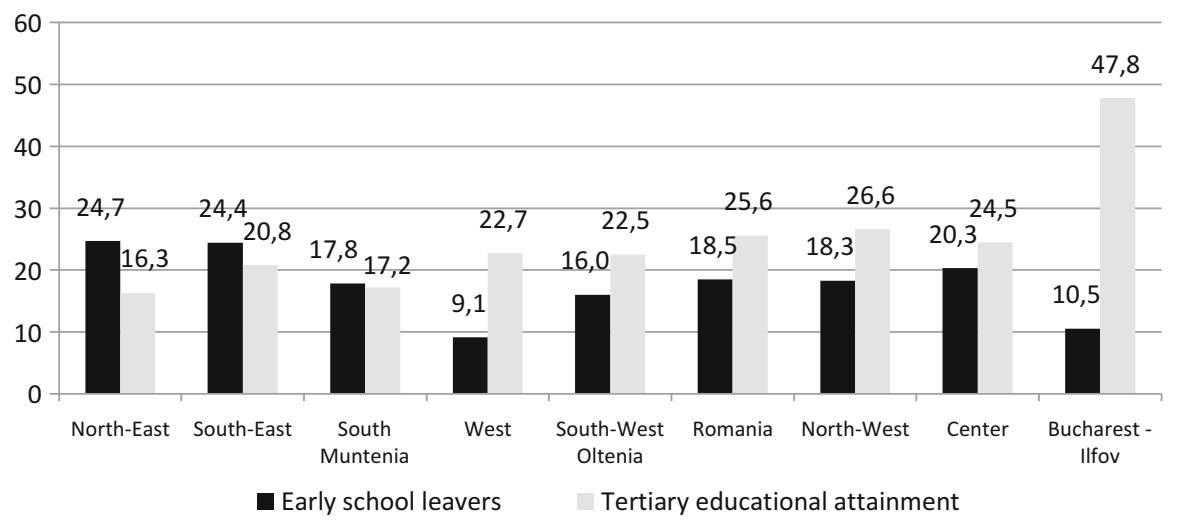

Fig. 5 The rate of early school leavers (18-24 years) and the tertiary educational attainment (30-34 years) in 2016 (\%). Source: Eurostat, variables edat_lfse_16 and edat_lfse_12

educational attainment was $26.6 \%$ (North-West) and, in all the other regions except the West, the rate of early school leavers was higher than $16 \%$. The poorest region, North-East, presents the opposite when compared with Bucharest-Ilfov: almost one quarter of those aged 18-24 did not complete the upper secondary level, and only $16.3 \%$ of those aged 30-34 years completed the higher education level (Fig. 5).

Analyzing the effect of changes in educational attainment in the entire adult population (aged 25-64 years), one can better observe the gaps between the Romanian regions of development (Table 2). Thus, the advance of Bucharest-Ilfov originated before 2000: the percentage of adult population with a high level of instruction was $20.1 \%$ in 2000 , at least double any other region, while the rate of early school leavers was approximately half of the rate of the other regions of development. Furthermore, while in 20 years one could observe a slow improvement in the level of educational attainment in almost all the regions, in the poorest region (North-East) there was merely a stagnation and even a slow increase in the percentage of persons with a low level of instruction (from $28.1 \%$ in 2007 to $30.7 \%$ in 2016). Also, in most of the regions, the improvement was more prominent before 2007 than after.

\section{Interpretation}

Generally speaking, we identified two types of gaps in education: external gaps (a moderate gap between Romania and the other countries in the post-communist group of countries, and a larger gap between Romania and other European countries) and internal gaps, which build a heterogeneous picture of Romania and are at the same time sources for the country gaps identified at first glance. The gaps manifest as polarizations not only between social categories but also between areas of residence and regions of development. 
Table 2 Population aged 25-64 in Romanian regions of development by level of educational attainment (2000, 2007, 2016-comparison)

\begin{tabular}{|c|c|c|c|c|c|}
\hline $\begin{array}{l}\text { Regions of development } \\
\text { (NUTS2) }\end{array}$ & Level of education & Level of education & 2000 & 2007 & 2016 \\
\hline \multirow[t]{3}{*}{ EU ( 28 countries $)$} & Low & ISCED 0-2 & & 29.3 & 23.1 \\
\hline & Medium & ISCED 3-4 & & 47.2 & 46.2 \\
\hline & High & ISCED 5-8 & & 23.5 & 30.7 \\
\hline \multirow[t]{3}{*}{ Romania } & Low & ISCED 0-2 & 30.7 & 25.0 & 23.3 \\
\hline & Medium & ISCED 3-4 & 60.0 & 63.0 & 59.4 \\
\hline & High & ISCED 5-8 & 9.3 & 12.0 & 17.4 \\
\hline \multirow[t]{3}{*}{ North-West } & Low & ISCED 0-2 & 33.0 & 25.8 & 24.5 \\
\hline & Medium & ISCED 3-4 & 58.2 & 63.1 & 58.1 \\
\hline & High & ISCED 5-8 & 8.8 & 11.0 & 17.4 \\
\hline \multirow[t]{3}{*}{ Center } & Low & ISCED 0-2 & 27.3 & 22.8 & 23.2 \\
\hline & Medium & ISCED $3-4$ & 64.4 & 66.0 & 59.3 \\
\hline & High & ISCED 5-8 & 8.3 & 11.1 & 17.5 \\
\hline \multirow[t]{3}{*}{ North-East } & Low & ISCED 0-2 & 34.5 & 28.1 & 30.7 \\
\hline & Medium & ISCED 3-4 & 58.7 & 61.6 & 57.7 \\
\hline & High & ISCED 5-8 & 6.8 & 10.3 & 11.5 \\
\hline \multirow[t]{3}{*}{ South-East } & Low & ISCED 0-2 & 33.8 & 30.0 & 28.2 \\
\hline & Medium & ISCED 3-4 & 57.4 & 61.2 & 58.9 \\
\hline & High & ISCED 5-8 & 8.8 & 8.8 & 12.9 \\
\hline \multirow[t]{3}{*}{ South-Muntenia } & Low & ISCED 0-2 & 33.6 & 27.8 & 23.8 \\
\hline & Medium & ISCED 3-4 & 59.9 & 63.6 & 63.0 \\
\hline & High & ISCED 5-8 & 6.5 & 8.6 & 13.3 \\
\hline \multirow[t]{3}{*}{ Bucharest-Ilfov } & Low & ISCED 0-2 & 16.7 & 13.2 & 13.0 \\
\hline & Medium & ISCED 3-4 & 63.2 & 60.4 & 51.9 \\
\hline & High & ISCED 5-8 & 20.1 & 26.3 & 35.1 \\
\hline \multirow[t]{3}{*}{ South-West Oltenia } & Low & ISCED 0-2 & 32.4 & 24.9 & 20.8 \\
\hline & Medium & ISCED 3-4 & 59.8 & 64.0 & 62.3 \\
\hline & High & ISCED 5-8 & 7.8 & 11.1 & 16.8 \\
\hline \multirow[t]{3}{*}{ West } & Low & ISCED 0-2 & 30.2 & 24.0 & 18.8 \\
\hline & Medium & ISCED 3-4 & 59.3 & 64.6 & 65.7 \\
\hline & High & ISCED 5-8 & 10.6 & 11.4 & 15.5 \\
\hline
\end{tabular}

Source: Eurostat, variable edat_lfse_04

The polarization can be identified starting from the participation rates. A high share of participation is a precondition for relevant academic achievements and for the quality of knowledge and skills gained by graduates. A share of more than $10 \%$ of pupils of the appropriate age not enrolled in primary school (which is the first compulsory level) reveals great social difficulties and a low level of motivation in the pupils' families. This share of children not enrolled in primary school not only creates a premise for lower shares of participation in the next levels but also determines the existence, in the future, of a large category of individuals with a total lack of basic skills for social life and qualifications. Meanwhile, analyzing 
participation in other levels of education, the cumulated levels of enrolment are the lowest in the case of Romania, showing that the premises for educational achievement are affected.

Depicting the internal disparities in Romania, a first important gap was observed when introducing residence as a structuring criterion: the rate of early leavers is 4.5 times higher in rural areas in comparison with cities, and 3 times higher in towns and suburbs in comparison with cities. Thus, a particular feature of Romania (and Bulgaria) is a profound educational inequality between different areas of residence. Secondly, an analysis of regions of development in Romania in terms of early school leaving, tertiary educational attainment and structure of population by level of instruction shows important inequalities: early school leaving is 2.5 times more intense in the poor regions (North-East) in comparison with Bucharest-Ilfov (compatible with the EU average, 11\%), while the tertiary education attainment in the total population of 30-34 years from Bucharest-Ilfov (48.4\%) is 3 times more than in the North-East (15.8\%). The premises for avoiding poverty and exclusion, for better health, building a successful career, and increasing earnings and family welfare are very different among the Romanian regions of development.

Moreover, while some of the Western European countries made important steps before 2007 to improve the share of population aged 30-34 with a high level of educational attainment and continued after 2007 (the cases of France, Belgium and Poland), other countries registered an accelerated improvement of this aspect after 2007 (Portugal, Italy and Greece). In this regard, Romania and Hungary had a similar pattern of evolution, which consisted of improving the share of population with tertiary educational attainment, but on behalf of the population with medium level of instruction (whose proportion decreased), while the share of population with a low level of educational attainment has remained almost at the same level in the last ten years. This pattern is worrisome because, in an organic development, the level of educational attainment should increase for all three categories of population. A relatively high share of the population with a low level of instruction means a high risk of poverty, social exclusion and a great range of other problems in the future for a large number of young people.

Finally, in terms of adult and young populations by level of instruction, even if in the last 20 years a gradual improvement is visible in Romania, the gap between the regions of development is more accentuated in the last period (the poorest regions, the North-East and, in some respects, the South-East present merely a stagnation).

\section{Discussion}

Education is a significant source of improvement of the human capital as a basis for welfare in the economy and society. There is a circular relationship between the development of human capital and the wellbeing of society (Glewwe and Muralidharan 2015, p. 3). At a social level, education has a positive influence on economic growth and improves the wellbeing of societies by forming informed and 
responsible consumers, increasing citizenship, democratic participation and, finally, the health and lifespan of the citizens (Wolfe and Haveman 2002; Lochner 2011). On the other hand, the labour market now needs to adapt to a new digital and globalized society and thus graduates should be more competent and specialized.

Several studies from the socio-economical field calculated the impact of education completion on individual earnings. Comparing census data for youth from the US, Canada and the UK, Oreopoulos (2003, p. 17) discovered that one year of compulsory schooling raises subsequent annual earnings by $10-14 \%$; also, a one-year increase in schooling decreases by $6 \%$ the probability of being reported as poor and by $3.2 \%$ the probability of reporting poor health in the US (Oreopoulos 2003, p. 18). Meanwhile, Rouse (2007) explored the impact of educational attainment level on employability status and income. Only 50\% of the individuals without high school completion were employed compared to $69 \%$ of individuals with a high school degree, and $75 \%$ of the individuals with at least a high school diploma. Further, high school dropouts contributed only $40 \%$ to tax revenues compared to employees with a high school diploma (Rouse 2007, p. 120), showing an important difference in income and demonstrating the importance of education.

These studies emphasize the positive impact of education on the life of individuals and reveal that increasing the quality of human capital by education contributes essentially to the shape of a post-industrialized, globalized society. Subsequently, the findings analyzed in this study raise pessimistic reflections about the future impact of the educational gaps in Romania. Due to the large differences among populations from the regions of development in terms of educational attainment, the human capital characteristics will be very different. Thus, the evolutions in the future will be divergent and no model of homogeneous development will be applicable. In vicious circles, the undesirable characteristics of the poorer development regions will intensify, making impossible the attempts to improve the situation (for example, attempts to launch local firms or subsidiaries for larger companies). Meanwhile, because a quarter of young people in rural areas (or one in six individuals in the whole adult population) have not completed the upper secondary education level, economic development will be affected in the future by the lack of qualified workforce. Also, this large proportion of individuals with a low level of instruction and employability is a source of social problems in the medium and long term, contributing to the intensification of poverty and crime. Moreover, the fact that one in ten children was not enrolled in the primary school level in 2015 (the lowest rate in the last twenty years) shows that the issue of this category of population, with all its consequences, will probably magnify in the future.

\section{Conclusions}

With the aim of identifying the differences in terms of educational disparities in Romania, the present research focused on the level of educational attainment, expressed by two key indicators (the rate of early school leaving and tertiary 
educational attainment - and, as support indicators, the gross enrolment ratio and the structure of population by the level of instruction). Relying on the last data released by Eurostat and UNESCO database, the study identified a series of educational gaps in Romania. First, the external gap placed Romania in the same group with Bulgaria and Hungary, on the one hand, and in the same group of countries with an important share of people with a low level of instruction (together with Spain, Portugal and Italy) on the other hand. In contrast to all of these countries, in Romania the share of population with a low level of instruction increased between 2000 and 2007 and did not decrease significantly after 2007.

Furthermore, the identification of internal educational disparities explains in part the external gaps of the country. Thus, the urban areas (cities, towns and suburbs) and the rural regions show large differences in terms of educational attainment and structure of population by level of instruction. These large differences create not only a very heterogeneous picture in the development of the Romanian urban and rural areas but also a mutual detachment when these gaps intensify in the future, producing "different worlds" whose tendency will be to evolve differently, in two opposite directions (progress versus underdevelopment). The impact of the educational gaps identified above will be very costly in the years to come, mainly when the population with a low level of instruction and weak qualifications and skills will be exposed to long-term unemployment, poverty, poor health, social exclusion, and higher crime rates. Therefore, new educational policies in Romania, focused on increasing the enrolment and the level of education attainment by stimulating the returns of education, should become a priority in the next decade.

\section{References}

Alexander, F. K. (2000). The changing face of accountability: Monitoring and assessing institutional performance in higher education. The Journal of Higher Education, 71(4), 411-431.

Buchmann, C., \& Hannum, E. (2001). Education and stratification in developing countries: A review of theories and research. Annual Review of Sociology, 27(1), 77-102.

Card, D. (1999). The causal effect of education on earnings. Handbook of Labor Economics, 3, 1801-1863.

Dale, A., \& Newman, L. (2005). Sustainable development, education and literacy. International Journal of Sustainability in Higher Education, 6(4), 351-362.

Duncan, G. J., Morris, P. A., \& Rodrigues, C. (2011). Does money really matter? Estimating impacts of family income on young children's achievement with data from random-assignment experiments. Developmental Psychology, 47(5), 1263-1279.

Ganimian, A. J., \& Murnane, R. J. (2016). Improving education in developing countries: Lessons from rigorous impact evaluations. Review of Educational Research, 86(3), 719-755.

Garcia, E., \& Weiss, E. (2015). Early education gaps by social class and race start US children out on unequal footing: A summary of the major findings in inequalities at the starting gate. Washington, DC: Economic Policy Institute.

Glewwe, P. W., \& Muralidharan, K. (2015). Improving school education outcomes in developing countries: Evidence, knowledge gaps, and policy implications. University of Oxford, Research on Improving Systems of Education (RISE). 
Glewwe, P. W., Hanushek, E. A., Humpage, S. D., \& Ravina, R. (2011). School resources and educational outcomes in developing countries: A review of the literature from 1990 to 2010 (Working paper 17554). Accessed January 19, 2018, from http://www.nber.org/papers/w17554

Harmon, C., Walker, I., \& Westergærd-Nielsen, N. C. (Eds.). (2001). Education and earnings in Europe: A cross country analysis of the returns to education. Cheltenham: Edward Elgar.

Hemphill, F. C., \& Vanneman, A. (2011). Achievement gaps: How hispanic and white students in public schools perform in mathematics and reading on the National Assessment of Educational Progress. Statistical Analysis Report. NCES 2011-459. National Center for Education Statistics.

Klasen, S. (2002). Low schooling for girls, slower growth for all? Cross-country evidence on the effect of gender inequality in education on economic development. The World Bank Economic Review, 16(3), 345-373.

Kremer, M., Brannen, C., \& Glennerster, R. (2013). The challenge of education and learning in the developing world. Science, 340(6130), 297-300.

Ladd, H. F. (2012). Education and poverty: Confronting the evidence. Journal of Policy Analysis and Management, 31(2), 203-227.

Lochner, L. (2011). Non-production benefits of education: Crime, health, and good citizenship (No. w16722). National Bureau of Economic Research.

Murnane, R. J., \& Ganimian, A. J. (2014). Improving educational outcomes in developing countries: Lessons from rigorous evaluations. Cambridge, MA: National Bureau of Economic Research.

Oreopoulos, P. (2003). Do dropouts drop out too soon? International evidence from changes in school-leaving laws (Working paper number 10155). National Bureau of Economic Research.

Reardon, S. F., Robinson, J. P., \& Waters, E. S. (2014). Patterns and trends in racial/ethnic and socioeconomic academic achievement gaps. In H. F. Ladd \& M. E. Goertz (Eds.), Handbook of research in education finance and policy (2nd ed., pp. 491-510). New York: Routledge.

Rouse, C. E. (2007). Consequences for the labor market. In C. Belfield \& H. M. Levin (Eds.), The price we pay: The economic and political consequences of inadequate education (pp. 99-124). Washington: Brookings Institution Press.

Sallis, E. (2014). Total quality management in education (3rd ed.). London: Kogan Page.

Wolfe, B. L., \& Haveman, R. H. (2002). Social and nonmarket benefits from education in an advanced economy. In Conference series-federal reserve bank of Boston (Vol. 47, pp. 97-131). Federal Reserve Bank of Boston, 1998.

Open Access This chapter is licensed under the terms of the Creative Commons Attribution 4.0 International License (http://creativecommons.org/licenses/by/4.0/), which permits use, sharing, adaptation, distribution and reproduction in any medium or format, as long as you give appropriate credit to the original author(s) and the source, provide a link to the Creative Commons licence and indicate if changes were made.

The images or other third party material in this chapter are included in the chapter's Creative Commons licence, unless indicated otherwise in a credit line to the material. If material is not included in the chapter's Creative Commons licence and your intended use is not permitted by statutory regulation or exceeds the permitted use, you will need to obtain permission directly from the copyright holder.

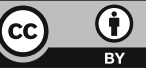




\title{
Europeanization in the Making: Perceptions of the Economic Effects of European Integration in Romania
}

\author{
Florența Toader and Loredana Radu
}

\section{Introduction}

The topic regarding public opinion towards the European Union has generated extensive debate in recent years. Starting with political leaders and official representatives of the EU and continuing with scholars and the media, the topic has garnered several points of view and explanations regarding the triggers that keep the public attached to the European project. The turning point for these discussions was firstly marked by the economic crisis in 2009, which brought a change of heart among Europeans regarding the capacity of the Union to adequately respond to the needs of citizens in different member states in times of economic turbulence. With the crisis came an increased distrust in the EU and a wave of criticism that evolved with the passing of the years.

Recent events such as the rising extremist and anti-European parties all over Europe and the spread of populist rhetoric are only a few examples of the type of challenges that today's EU is facing in order to maintain its existence. According to the Standard Eurobarometer published August 2017, more than four in ten Europeans, representing $42 \%$ of the total sample, trust the European Union. Comparing this percentage with the results of a Eurobarometer published in the autumn of 2015, trust in the EU has increased by $10 \%$. However, the crisis that the EU is facing is far from over, and the topic of shifting attitudes towards the EU still stands. The same Eurobarometer (August 2017) shows that Eastern-European states such as

This chapter has been prepared with financial support granted in the project "State of the Nation. Designing an innovative instrument for evidence-based policy-making" (SIPOCA 11, MySMIS 118305), which is co-financed by the European Social Fund through the Operational Programme Administrative Capacity 2014-2020.

F. Toader $(\bowtie) \cdot$ L. Radu $(\bowtie)$

National University of Political Studies and Public Administration, Bucharest, Romania e-mail: florenta.toader@comunicare.ro; loredana.radu@ comunicare.ro 
Lithuania (65\%), Romania (57\%) and Bulgaria (54\%) maintain a strong Eurooptimistic orientation. In Romania's case, it is still challenging to explain the pro-European attitude considering that the economic benefits post-integration do not support such a high level of backing for the EU. In this sense, Romanians perceive the economic situation as the third most important concern of the Union (Eurobarometer, August 2017). Still, 67\% of the Romanian respondents are optimistic regarding the future of the EU.

In this context, the following contribution attempts to explain Romanians' trust in the EU despite little economic progress after the European integration and low salience of European issues in the Romanian public space. The chapter builds on previous qualitative research conducted by Fomina and Radu (2017), which assesses public attitudes towards the EU among students from Poland and Romania. The present study, however, focuses exclusively on the Romanian realm and has a quantitative approach, using data collected through a national omnibus survey conducted in September 2017 and secondary data analysis concerning the economic effects of European integration.

\section{The Utilitarian Approach to EU Support}

When assessing the different predictors of trust in the EU, scholars usually differentiate between economic interests, group identities, and political rhetoric. According to de Vreese and his collaborators (2008), support towards European integration is given not only by utilitarian predictors (economic interests), also called hard predictors, but also by soft predictors such as the degree of identification with one's national identity or the attitude towards migrants. Continuing this idea, Boomgaarden et al. (2011) identify specific and diffuse models of support towards the EU. Specific support is based on concrete policy outcomes or performance while diffuse support derives from the evaluation of the core values of the Union.

According to the utilitarian model, the aspects that influence attitudes towards the EU are based on calculi regarding the benefits of integration over the national economy (Hooghe and Marks 2004). In other words, people tend to have more trust in Europe in times of economic growth and attribute their own country's wellbeing to European integration. The level of trust in the European project decreases when the EU's economic performance is weaker. As a result, this type of support is dependent on short-term results (Boomgaarden et al. 2011) and on subjective evaluations regarding the future of the economy (De Vreese et al. 2008; Bârgăoanu et al. 2013). When any perceived benefits are low or challenged by crisis situations, trust in the EU drops.

Given its subjective matter, the utilitarian view of the benefits of EU integration can manifest itself both at a macro and micro level (Fomina and Radu 2017). At a macroeconomic level, attitudes towards the EU are shaped by the increase in the 
level of international trade (Eichenberg and Dalton 1993). At the micro level, people shape their attitude towards the European project based on the impact integration had on their lives from an economic point of view. Authors such as Anderson (1998) proved that European citizens use their own country's performance when evaluating the EU. At the same time, assessments of the national and supranational performance of government are connected and influence each other (Harteveld et al. 2013). Therefore, the levels of satisfaction regarding the functioning of the national institutions and democracy together influence how citizens appraise EU democracy.

Still, not all citizens evaluate the economic impact of integration over their lives in the same manner. As studies show (Anderson and Kaltenthaler 1996; Gabel 1998), citizens with larger human capital usually have more opportunities to benefit from European integration. As a result, citizens that were already doing well economically tend to have more trust in the EU. Another important factor is the region of residence. As Gabel (1998) notes, residents of frontier countries of the EU are usually more Euro-optimistic as they draw more benefits from the free circulation of goods and people across the EU. This theory is usually used to explain Eastern-European countries' trust in the EU. According to this view, Eastern-European countries with weaker democracies and economies benefit economically from European integration, hence their support for integration. At a macroeconomic level, attitudes towards the EU are shaped by the increase in the level of trade (Eichenberg and Dalton 1993).

However, the utilitarian view regarding public support towards the EU has several shortcomings that need to be addressed. Firstly, according to the synthesis made by Fomina and Radu (2017), the average citizen does not have the capacity to accurately assess the effects of European integration on a personal level. This ability is even more limited when talking of a precise evaluation of changes in foreign trade. This assumption however overlooks the lack of knowledge about the EU, which citizens from different member states experience differently. For instance, in Romania the inclusion of EU issues on the public agenda is limited, therefore no amount of citizen evaluation of the EU performance, based on national performance, can explain the trust Romanians still have in the EU. This aspect is once more important in the context in which Romanians perceive the economic situation of their country as a main source of concern (Standard Eurobarometer, August 2017), and the low economic growth after the integration backs up this concern. It has been proven therefore that the utilitarian view has several limitations. While this approach is useful to explain "the emergence of intra-EU cleavages" between "the rich Westerners and the poor Easterners" (Fomina and Radu 2017), it is mostly based on artificial discrepancies between countries with strong economies and developing European countries. Moreover, utilitarian thinking shows its limits in specific cases such as Poland or Hungary - two European countries that greatly benefitted from European funds but in recent years have developed a strong Eurosceptic attitude. Moreover, studies have demonstrated the limits of the neoliberal view according to which a citizen is exclusively a homo economicus, concerned solely with the economic aspects of their life. 


\section{Soft Predictors of EU Support}

According to de Vreese and his collaborators (2008), besides hard predictors of EU support (based on economic calculi), soft predictors should also be taken into consideration. The same idea is supported by scholars such as Boomgaarden et al. (2011), De Vries (2010), and De Vries and Hobolt (2012). According to these authors, evoking strong emotions is a good tactic to mobilize voters around issues related to EU integration. From this point of view, one can include in the category of soft predictors of attitudes towards the EU the symbolic meaning of EU membership. This type of reasoning emerged because of the changes the European project experienced years after the Maastricht treaty signing and the adoption of the expansion policy of the Union. More countries were dissatisfied with the integration of less developed states, which can shake the economic balance of the EU. Another consequence of these transformations was that more states started to adopt a type of rhetoric that militated towards the conservation of the integrity of the national state and its culture. This type of reaction can be explained through the fact that with the passing of the years, the EU has drifted away from its initial purpose-economic cooperation. Based on this theory, Hooghe and Marks (2004, 2005) noted that national identity-related aspects are central to the process of formation of attitudes towards the EU.

Studies on Euroscepticism place at the core of this view the idea of indivisibility of the nation-state. According to this view, European integration is illegitimate since it transfers political power from the national state to a different political entity. Without EU interference, states would be perfectly able to deal independently with the different challenges they face-the economic crisis, the immigrant crisis, etc. According to Fomina and Radu (2017), these arguments against EU integration can be ultimately reduced to the averseness of different national states towards multilevel governance. At this level, national identity and values are threatened by the fact that the EU as a supranational organism infuses foreign values and norms. Still, we argue that the symbolic meaning of EU membership can also lead to positive attitudes towards the Union. In this case, citizens' evaluation of EU values as being desirable compared to the policies conducted by internal government can be a strong predictor of Euro-optimistic attitudes.

At the same time, political cues coming from political parties also play a role in the process of attitude formation towards EU integration. Recent studies such as that conducted by Rohrschneider and Whitefield (2016) have proven that Eurosceptic attitudes are also shaped by the orientation of mainstream and extremist parties towards the EU. According to these authors, in economically consolidated states, mainstream parties, especially those representing the right-wing, maintain a pro-European discourse as they were involved in the building of the European project. Adopting a different approach might foster imagological and credibility problems. At the opposite side of the political spectrum, extremist parties tend to adopt a Eurosceptic rhetoric, drawing on the shortcomings of European integration. This tendency is mostly present in Western Europe, where states have been involved 
since the beginning in the process of building the EU. Moreover, parties that evolved there after 2008-2009 are even more Eurosceptic as they were created specially to criticize and delegitimize the EU. However, this is not the case for parties in Central and Eastern Europe. These parties still have a pro-integration rhetoric as they are concerned with other political issues, and the imagological investment in this topic is lower than in the West.

The last factors of EU attitude formation discussed above-concerns related to national state integrity, national identity, and political cues-are interconnected. National identity does not necessarily exclude European identity, even though the latter is usually less consolidated. The type of national identity, however, may impact the way citizens evaluate issues concerning the EU (Hooghe and Marks 2005; Luedtke 2005; Bruter 2008; Van Klingeren et al. 2013). According to De Vries and Edwards (2009), countries have either inclusive or exclusive identities. Countries with inclusive identities tend to be more Euro-optimistic while the ones with an exclusive national identity are more prone to reject the European values. This observation is important because citizens coming from the latter categories of countries are more exposed to the influence of political framing and cueing and, in the end, can perceive European integration as a threat to national identity. They are also more vulnerable to Eurosceptic propaganda (Fomina and Radu 2017). Moreover, studies (Hooghe and Marks 2005) show that in national contexts where elites share consent over European integration, national and European identities are complementary. This is not the case for states where elites disagree over integration. In the latter contexts, national identity can foster Euroscepticism. As Fomina and Radu (2017) note, "Since the European identity is still much weaker than the national identities, many citizens may strongly believe that decisions should be taken on the national rather than the European level, not because of efficiency concerns, but because it reflects the collective will of the group they identify stronger or exclusively with". This approach goes beyond the initial goal of the EU, which was economic cooperation, and focuses on aspects such as the preservation of culture and traditions.

Our assumption in this chapter is that Romanians' attitudes towards the EU are shaped mainly by soft predictors such as the meaning of EU integration and identityrelated issues. For example, the pro-European attitudes in a country where Europeanization is still "in the making", 10 years after integration, are the perceived desirability of European values versus other geopolitical options and the disappointment with the national political institutions. While most of the studies aiming to measure patterns of EU support have been conducted in rather stable times, the present research sheds light on this topic in a time characterized by several ongoing EU crises (e.g. euro crisis, sovereign debt crisis, refugee crisis, Brexit). 


\section{Methodology}

The goal of the present chapter is to observe and explain patterns of EU support in Romania, a country that continues to keep its pro-European orientation despite little economic progress after the European integration and low salience of European issues in the Romanian public space. We challenge one of the most frequent approaches towards EU support: the utilitarian theory, according to which Eastern-European citizens' perceptions of the EU are shaped by the economic benefits brought by integration. In this regard, the following research objectives and hypotheses were set:

Ob.1 To investigate the impact of EU integration on Romania's economic performance based on the following indicators-GDP and GDP per capita, evolution of public debt, and the absorption of EU funds;

H1. The evolution of the Romanian GDP per capita / public debt / absorption of EU funds does not support the utilitarian view of EU support in Romania;

Ob.2 To investigate Romanian citizens' perceptions of the economic development of the country in the CEE region;

H2. Romanian citizens' evaluation of national economic performance is lower compared to other EU member states;

H3. Romanian citizens' evaluation of personal economic performance is lower compared to other CEE member states;

Ob.3 To investigate Romanian citizens' trust in the local political institutions as compared to the EU;

H4. Romanians tend to trust the European Union more than they trust internal political institutions;

Ob.4 To investigate Romanian citizens' perception of the impact EU funds has on the economic growth of the country;

H5. Romanian citizens perceive EU funds as having a positive impact on the national economy;

Ob. 5 To investigate Romanian citizens' personal evaluation of their life quality and its correlation with EU support.

H6. The better Romanians evaluate their life satisfaction, the greater is their trust in the EU.

In order to meet the research objectives, our study is structured in two parts. The first step of the study is to analyze hard data on the economic effects of European integration to verify if hard data regarding the state of the Romanian economy support the utilitarian thesis. The data presented in this contribution, ranging from 1987 to 2016, have been collected from public resources in the project The State of the Nation. The development of an innovative instrument for grounding the development of public policies in Romania and offer an overview of the evolution of the Romanian GDP and GDP per capita, the public debt, and the absorption of European funds. The second part of the study consists of quantitative research of Romanian citizens' perception of the economic impact of European integration. In this regard, 
a survey was conducted, in September 2017, on a representative sample of 1107 respondents in order to gather data regarding citizens' evaluation of the state of the Romanian economy and their personal economic performance post-integration as well as their trust in internal and external political actors (political institutions, supranational organization, states, etc.).

\section{Data Presentation and Interpretation}

In the following section, the results of the study will be presented and discussed, starting with the evidence brought by hard data regarding the economic effects of EU integration and continuing with the results of the national omnibus survey.

\subsection{The Economic Effects of EU Integration in Romania: Average Growth, Great Inequalities}

Public data regarding the evolution of Romania's GDP between 1987 and 2015 show that European integration constituted an impulse for the growth of the Romanian GDP, especially compared with its values before 2007. Immediately after the anti-communist revolution, the country's GDP suffered a drop because of the political turbulence and the transition towards the capitalist economy. It took Romania 18 years to recover to a GDP value comparable with the one before the revolution. The peak in terms of GDP was reached in 2008, 1 year after the EU integration (208,181,626,901 dollars), but dropped to $167,422,949,529$ dollars in 2009 and has fluctuated ever since. Compared to other Eastern-European countries, the evolution of Romania's GDP in the last 20 years is average. For example, in 1990 Romania's GDP represented 59.1\% of Poland's GDP. This value dropped to $37.3 \%$ in 2015 . These numbers show that Romania has performed rather well economically after EU integration but is still behind CEE countries such as Poland, where the economic benefits of EU integration are more visible. Lastly, Romania's GDP depends on the economic performance of the Bucharest-Ilfov region and there are still great economic cleavages between the urban and the rural areas.

Efforts towards integration have led to a rise in the country's GDP, which might constitute a basis for the utilitarian approach to EU support. This can be explained by the implementation of different regulations negotiated by Romanian politicians as part of the integration agreement as well as by the attraction of new foreign investments as a result of the newly gained international trust generated by integration negotiations. During that time, the media and political discourse in Romania were optimistic towards the integration policies and the positive economic outcome that this process will foster. The Romanian economy became more stable and this can also explain the increase of the GDP. The fluctuations that followed the initial 
enthusiasm of EU integration reflects both the effect of the economic crisis in 2009 and a process of normalization of the Romanian economy and politics, which became business as usual after joining the EU.

When studying how these numbers reflect the economic wellbeing of Romanian citizens compared to citizens from other countries in the Eurozone, one can see that the utilitarian hypothesis of EU support no longer stands. In the last 10 years, Romania has not managed to reduce the disparities with the Eurozone as far as the economic wellbeing of its citizens is concerned. This is especially relevant as Romania's population has dropped considerably in this interval due to migration and low natality. Therefore, even though in absolute terms Romania has seen progress in terms of GDP after the EU integration, this is not reflected in the GDP/capita, which is an important indicator of citizens' economic wellbeing. Compared to other CEE countries, Romania is only above Bulgaria in terms of GDP/capita but has had modest growth in comparison with Slovenia, the Czech Republic, Hungary and Slovakia. Moreover, there are regions in Romania that barely reach $40 \%$ of Bucharest's performance in terms of GDP per capita, while other regions only reach $25 \%$ or $30 \%$ of the economic welfare of the Romanian capital. The gap in terms of GDP/capita between Bucharest and other regions has increased significantly in the last 15 years. The same trend can be observed when analyzing the gap between GDP/capita in urban and rural areas, with the latter being less economically productive. This reveals several cleavages between the Romanian regions and an unequal distribution of the economic wellbeing in the country.

Romania has cultivated a model of economic development based on the growth of the public debt. Compared to other CEE countries, Romania is performing well in terms of public debt, inn third place after Slovenia and Slovakia. However, the weight of the public debt on the GDP tripled during and after the economic crisis. While countries such as the Czech Republic and Bulgaria managed to reduce their public debt, in Romania the value of the debt increases year by year.

In terms of absorption of EU funds, the hard data collected from public sources starting January 2009 until November 2016 show that there is a constant growth of the absorption of European funds, but this growth has been slow-Romania has barely absorbed $45.5 \%$. Moreover, the monthly growth of absorption is unstable, which means that the growth is not constant. On average, the monthly absorption of European funds is $1.06 \%$, with a maximum of $3.6 \%$ reached in January 2016. While this indicator is also correlated with local government performance, the figures show that Romania is not one of the best players when talking about absorption. As a consequence, while some Romanian citizens might directly benefit from the absorption of EU funds, this is not an indicator that might support a positive evaluation of the EU as economic benefits cannot be felt by the majority of the citizens.

We corroborate the hard data analyzed above with the results of the omnibus survey conducted in September 2017 to see if the degree of trust in the EU has changed in the last year, and to what extent economic evaluations contribute to Romanian citizens' Euro-optimism. Still, the hard data analyzed here reflect the media discourse in terms of national government performance and the country's economic performance. Topics such as the lack of impact of economic growth on the 
lives of the regular citizens are largely discussed in the media. This type of discussion in turn can have a great impact on the way Romanians evaluate the EU beyond the economic benefits of integration. Romanians disappointed by their local politicians can look towards the EU as a model of economic organization and political performance. Their support for the Union goes beyond economic calculi and enters the realm of personal preference towards a political system perceived as more effective.

\subsection{Pessimistic Economic Evaluations and Soft Euro-Optimism}

The data collected through the national survey show Romanian citizens have a rather pessimistic view of economic growth following EU integration. Overall, $66.8 \%$ of the participants in the survey stated that Romania is heading in the wrong direction. At the same time, evaluation of life quality is rather low, with approximately $60 \%$ of respondents saying they are rather unsatisfied with the quality of their life. Moreover, $43.2 \%$ of Romanians say their economic situation in 2017 is the same as in the previous year, while $35.8 \%$ say their economic situation worsened. When asked about their predictions for the standard of living in 2018, the respondents had reserved attitudes, with $26 \%$ expecting a better quality of life, $31.3 \%$ saying that their current situation will remain unchanged and $30.5 \%$ expecting a worse year than 2017.

According to the utilitarian approach to EU support, these numbers would suggest that, based on the subjective evaluation of their life quality and economic performance, Romanians are rather unsupportive of the European Union. However, the results of the survey show that $59.4 \%$ of the respondents have a high level of trust in the EU, while $6.7 \%$ say their level of trust in the Union is very high. The only international actor that competes with this level of trust is NATO, with $52.8 \%$ of the respondents saying they have great trust in this organization, while $6.9 \%$ trust it very highly. Compared with trust shown for other internal and external actors (political institutions, economic funds, states) - see Fig. 1, the results show that Romanians tend to trust supranational organizations more than they trust their internal political institutions or the media.

The weak level of trust in the presidency, parliament, government, justice and political parties implies that Romanians are disappointed with the way internal institutions respond to the needs of the citizens. In this sense, the results of the study show a correlation between the disappointment with the internal justice system and a higher level of trust in the EU $(\mathrm{X} 2(30)=388.984, \mathrm{p}<0.1)$. The same correlation is available in the case of a lower level of trust in the presidency (X2 $(25)=232.181, \mathrm{p}<0,1)$, parliament $(\mathrm{X} 2(25)=423.045, \mathrm{p}<0.1)$, government $(\mathrm{X} 2$ $(25)=158.490, \mathrm{p}<0.1)$ and the political parties $(\mathrm{X} 2(25)=381.916, \mathrm{p}<0.1)$. At the same time, a lower trust in Russia as opposed to the EU confirms the results of 


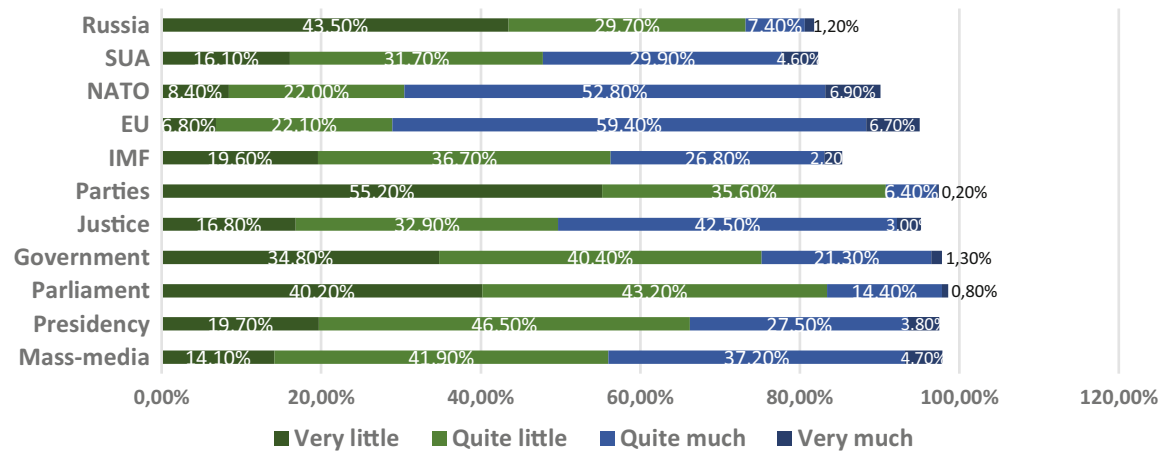

Fig. 1 Level of trust in internal and external actors (political institutions, supranational organizations, economic funds, states)

previous studies (Fomina and Radu 2017) that show that the preference for the EU is "an important geopolitical choice, and an alternative to the Russian hegemony". A possible explanation for these results, which should be further investigated through qualitative research, is that Romanian citizens look up to organizations with strong values and durable strategies, are seen as desirable models against ineffective internal policies and political institutions or threatening geopolitical neighbors.

In line with Romanians' disappointment with internal authorities, the results of the survey show a lower level of satisfaction with Romania's economic growth level, with approximately $77 \%$ of the respondents being rather unsatisfied. When asked to evaluate Romania's economic growth compared to other EU countries or other CEE countries, the respondents are rather pessimistic. For example, 90\% of the respondents assess Romania's economic growth compared to other EU countries as low or very low, while $80 \%$ say that Romania performs poorly from an economical point of view as opposed to other CEE countries such as Poland, the Czech Republic, and Hungary. Overall, approximately $33 \%$ of Romanians consider that the country is performing better economically than it did before the EU integration in 2007, and nearly $40 \%$ consider that the country is underperforming in the same sector.

Results show a correlation between the level of life satisfaction and the evaluation of Romania's economic performance after 2007 (X2(25) = 128.442, p < 0.1) those who evaluate their life satisfaction as higher are more likely to believe that Romania has improved economically since 2007, and those who are less satisfied with their overall quality of life are less inclined to see any progress after EU integration. Still, there is no correlation between EU trust and the area of residence (urban or rural) or the region of residence (Bucharest-Ilfov or other Romanian regions). These results partly confirm the internal cleavages between citizens and NUTS 2 regions, as also revealed by the analysis of hard data regarding the economic effects of EU integration.

Furthermore, when asked if the Romanian government is doing a good job of managing public money, $78.7 \%$ of the respondents assessed the government's 
performance as rather poor. A solution to Romania's poor economic situation can be EU funds (59\% of the respondents consider them highly useful for economic development). However, respondents evaluate the use of these funds as mostly ineffective. This confirms citizens' disenchantment with the local government and a latent utilitarian approach to EU membership. While the EU is seen as a positive model as opposed to the unsatisfactory performance of internal institutions, the Union is as well perceived as a source of economic growth through EU funds. The local authorities' management of such funds, however, is seen as an impediment to economic progress. Still, regardless of Romanians' pessimistic economic self-evaluation, they still maintain trust in the positive economic outcome of EU membership.

\section{Concluding Remarks}

The results of this study show little support for the utilitarian approach to EU support among Romanian citizens, therefore the first hypothesis is validated. In terms of GDP, integration has meant visible growth compared to the interval prior to 2007. However, this is not reflected in the most important indicator of citizens' economic wellbeing-GDP/capita, which is still low in Romania compared to other CEE countries. Even though Romania's economy has made some progress after integration, economic growth at this point is still the result of an increase in public debt rather than from production or investments. At the same time, even though the absorption of EU funds has increased, it is still too low to make a positive impact on economic growth.

The data collected through the national survey is complementary to the results of the secondary data analysis. Romanian citizens view the economic performance of their country pessimistically compared to other EU member states, and state that Romania is heading in the wrong direction. A negative evaluation is also given to personal economic performance, which is expected to either remain the same in 2018 or worsen. When comparing their economic performance to that of other citizens in CEE member states, Romanians state that they are less economically performant. Therefore, the second two hypotheses are confirmed. At the same time, in terms of trust, Romanian citizens tend to trust supranational organizations such as the EU and NATO more than they trust the presidency, parliament, government and internal justice system, confirming thus the fourth hypothesis of our study. The lack of trust in the government can be associated with a lack of satisfaction with its policies and ability to adequately manage the public money. Lastly, the fifth hypothesis of this study was invalidated: while EU funds are seen as a potential source of growth for the Romanian economy, citizens believe that these funds are not used adequately in order to positively impact the country's economy.

Overall, Romanian citizens' evaluation of national and personal economic performances indicates a strong level of pessimism. However, this does not influence the trust Romanians have in the EU. Therefore, the sixth hypothesis of our study is 
invalidated. Trust in the EU cannot be explained through hard predictors, although Romanians' confidence in EU funds contributing to economic growth may indicate a latent utilitarian evaluation of European membership. Given the results of this study, the strong trust Romanians have in the European project can be more accurately explained by soft predictors - a trend that we have named soft euro-optimism. From this point of view, the symbolic meaning of EU membership, which is perceived as desirable compared to other geopolitical options, and the disappointment with internal political institutions are better explanatory factors for the apparent unreserved support Romanians have for the European Union. The results of this study are in line with previous research on the same topic (Fomina and Radu 2017) and could benefit from further qualitative investigation. Still, the trend shown by this study is that in Romania, where EU political issues are still rarely discussed in the public sphere and where trust in the national political institutions and media system is low, the EU continues to keep its aura of desirability for Romanian citizens. This reveals a paradox of Europeanization in the making: the lower the level of information about EU affairs and trust in the local government, the higher the trust in the EU.

\section{References}

Anderson, C. J., \& Kaltenthaler, K. C. (1996). The dynamics of public opinion toward European integration, 1973-93. European Journal of International Relations, 2, 175-199.

Anderson, C. J. (1998). When in doubt, use proxies: Attitudes toward domestic policies and support for European integration. Comparative Political Studies, 31(5), 569-601.

Bârgăoanu, A., Corbu, N., \& Radu, L. (2013). The role of government evaluations and EU identity in shaping economic expectations during the crisis. The case of Romania. European Journal of Science and Theology, 9(4), 225-241.

Boomgaarden, H. G., van Spanje, J., Vliegenthart, R., \& de Vreese, C. H. (2011). Covering the crisis: Media coverage of the economic crisis and citizens' economic expectations. Acta Politica, 46, 353-379.

Bruter, M. (2008). Legitimacy, Euroscepticism \& identity. European Union Journal of Contemporary European Research, 4(4), 273-285.

De Vreese, C. H., Boomgaarden, H. G., \& Semetko, H. (2008). Hard and soft: Public support for Turkish membership in the EU. European Union Politics, 9(4), 511-530.

De Vries, C. (2010). EU issue voting: Asset or liability? European Union Politics, 11(1), 89-117.

De Vries, C., \& Hobolt, S. (2012). When dimensions collide: The electoral success of issue entrepreneurs. European Union Politics, 13(2), 246-268.

De Vries, C., \& Edwards, E. (2009). Taking Europe to its extremes: Extremist parties and public Euroscepticism. Party Politics, 15(1), 5-28.

Eichenberg, R., \& Dalton, R. (1993). Europeans and the European Community: The dynamics of public support for European integration. International Organization, 47(4), 507-534.

Fomina, J., \& Radu, L. (2017). Who's afraid of the "big bad wolf"? A qualitative assessment of Poles' and Romanians' attitudes towards the European Union. In Inquiring communication through qualitative research. Newcastle: Cambridge Scholars Publishing.

Gabel, M. (1998). Public support for European integration: An empirical test of five theories. The Journal of Politics, 60(2), 333-354.

Harteveld, E., van der Meer, T., \& de Vries, C. (2013). In Europe we trust? Exploring three logics of trust in the European Union. European Union Politics, 14(4), 542-565. 
Hooghe, L., \& Marks, G. (2004). Does identity or economic rationality drive public opinion on European integration? Political Science and Politics, 37(3), 415-420.

Hooghe, L., \& Marks, G. (2005). Calculation, community and cues: Public opinion on European integration. European Union Politics, 6(4), 419-443.

Luedtke, A. (2005). A Europe of the regions: Rhetoric or reality? International Studies Review, 7 (1), 101-103.

Rohrschneider, R., \& Whitefield, S. (2016). Responding to growing European Union-skepticism? The stances of political parties toward European integration in Western and Eastern Europe following the financial crisis. European Union Politics, 17(1), 138-161.

Standard Eurobarometer. (2017, August). Accessed November 22, 2017, from http://ec.europa.eu/ commfrontoffice/publicopinion/index.cfm/Survey/getSurveyDetail/instruments/STANDARD/ surveyKy/2142

Van Klingeren, M., Boomgaarden, H. G., \& de Vreese, C. H. (2013). Going soft or staying soft: Have identity factors become more important than economic rationale when explaining Euroscepticism? Journal of European Integration, 35(6), 689-704.

Open Access This chapter is licensed under the terms of the Creative Commons Attribution 4.0 International License (http://creativecommons.org/licenses/by/4.0/), which permits use, sharing, adaptation, distribution and reproduction in any medium or format, as long as you give appropriate credit to the original author(s) and the source, provide a link to the Creative Commons licence and indicate if changes were made.

The images or other third party material in this chapter are included in the chapter's Creative Commons licence, unless indicated otherwise in a credit line to the material. If material is not included in the chapter's Creative Commons licence and your intended use is not permitted by statutory regulation or exceeds the permitted use, you will need to obtain permission directly from the copyright holder. 


\section{Correction to: Health Care and Migration: What Data Can Tell Us of the Hard-to- Measure Impact of Migrants on the European Health Systems}

Guidi Caterina Francesca and Alessandro Petretto

\section{Correction to:}

Chapter 11 in: P. Dobrescu (ed.), Development in Turbulent

Times, https://doi.org/10.1007/978-3-030-11361-2_11

In Page 153:

The chapter was inadvertently published with the incorrect author name and later the same has been updated as Guidi Caterina Francesca. 